\title{
Results of coalbed methane drilling in Panola County,
}

\section{Texas}

Edited by Peter D. Warwick, John R. SanFilipo, Alex W. Karlsen, and Charles E. Barker

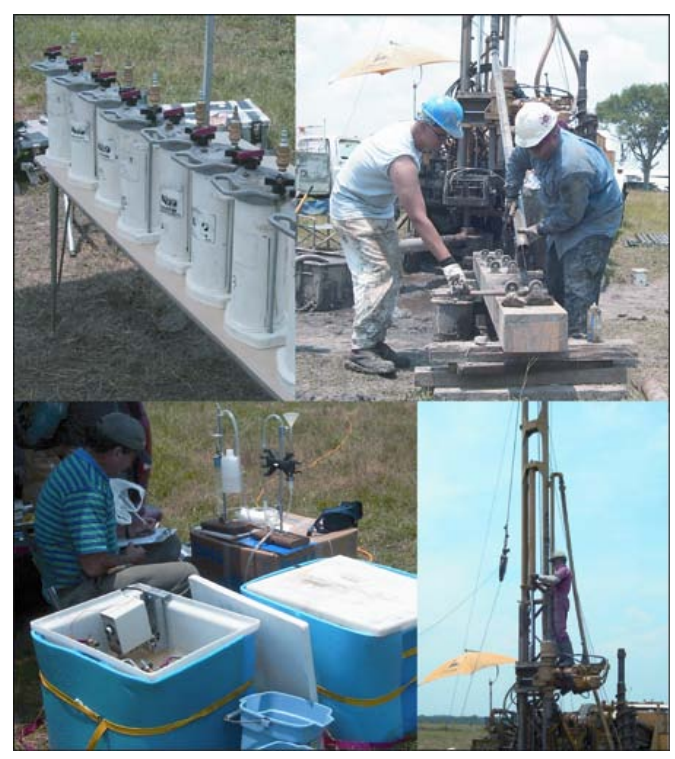

This report is preliminary and has not been reviewed for conformity with U.S. Geological Survey editorial standards and stratigraphic nomenclature. Any use of trade names is for descriptive purposes only, and does not imply endorsement by the U.S. Geological Survey.

Open-File Report 2005-1046

U.S. Department of the Interior

U.S. Geological Survey 


\section{Contents}

\section{Chapter 1 Introduction}

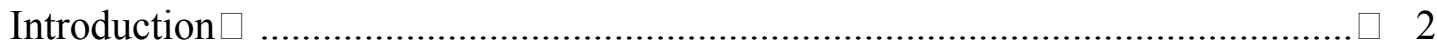

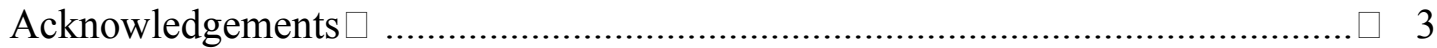

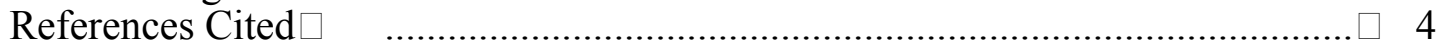

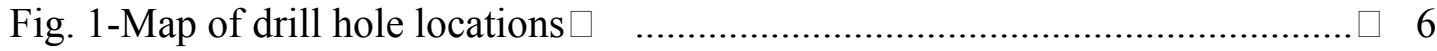

Chapter 2 Field Core Descriptions

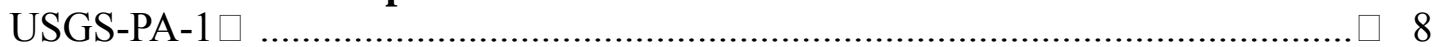

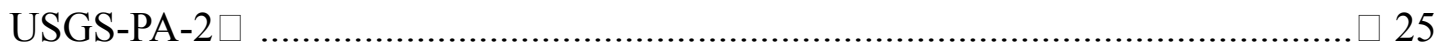

Chapter 3 Laboratory Coal Core and Tonstein Descriptions

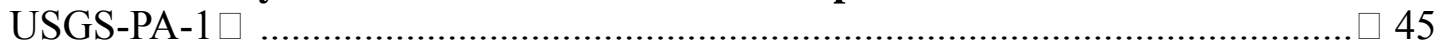

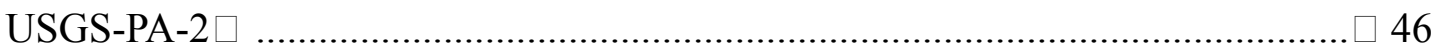

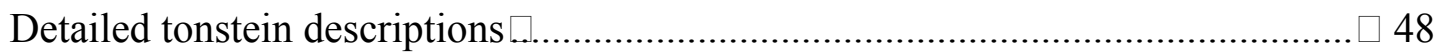

Chapter 4 Geophysical Logs

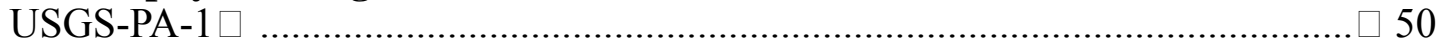

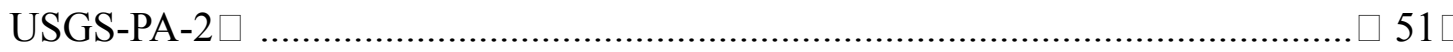

Chapter 5 Petrographic Data

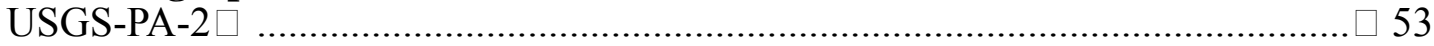

\section{Chapter 6 Pollen Data}

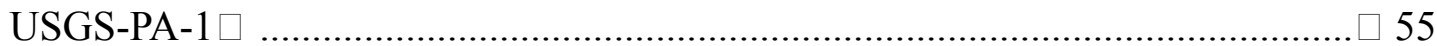

USGS-PA-1 Palynology Sample Index $\square \quad$..................................... $\square 63$

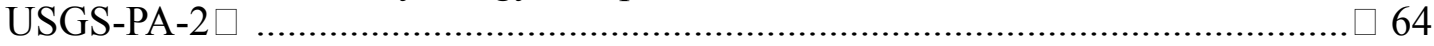

USGS-PA-2 Palynology Sample Index $\square \quad$......................................... $\square 71$

\section{Chapter 7 Dinocyst Data}

USGS-PA-2

Chapter 8 Methane Desorption

USGS-PA-2

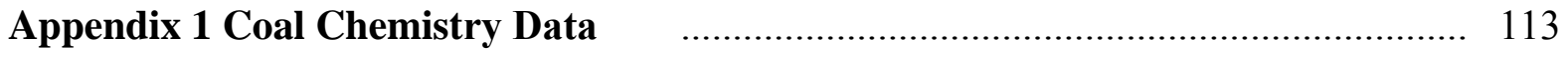

Appendix 2 Methane Adsorption Isotherms $\quad$............................................... $\square 117$

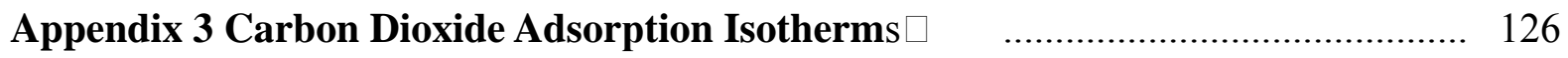

Appendix 4 Extended Langmuir Modeling $\quad$................................................. $\square 129$

Appendix 5 Gas Analysis of USGS-PA-2-CN13 …............................................ $\square 142$

Appendix 6 Drilling permit .......................................................................... $\square 144$

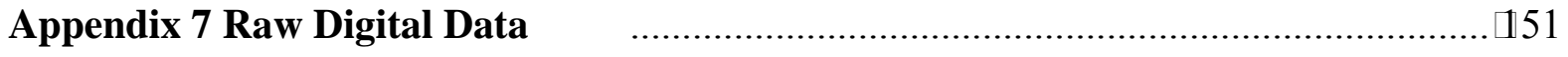




\section{Chapter 1}

\section{Introduction to drilling operations in Panola County,}

\section{Texas}

By Peter D. Warwick

Chapter 1 of

Results of coalbed methane drilling in Panola County, Texas

Edited By Peter D. Warwick', John R. SanFilipo', Alex W. Karlsen', and Charles E. Barker²

'U.S. Geological Survey, Reston, VA

${ }^{2}$ U.S. Geological Survey, Denver, CO

Open-File Report 2005-1046

U.S. Department of the Interior

U.S. Geological Survey 


\section{Introduction}

From June 13 to June 28, 1999, the U.S. Geological Survey (USGS), in cooperation with the Texas A\&M University, drilled and continuously cored two coalbed methane test wells in the lower Wilcox Group (Paleocene) of Panola County, Texas. This report presents data obtained from the drilling and analytical program. The locations of the test wells (USGS-PA-1 and USGS-PA-2) are shown on figure 1. The rock core obtained from this drilling project is in storage at the Texas A\&M University Department of Geology and Geophysics. The purpose of this report is to release the raw data obtained from these two test wells. Preliminary interpretive reports generated from this data include Warwick and others $(1999 ; 2000 a, b ; 2002)$ and SanFilipo and others (2000a,b). This report consists of: detailed rock core descriptions and selected core photographs from both wells (Chapter 2); detailed laboratory descriptions of the coal and associated rock (Chapter 3); plots of the geophysical logs (natural gamma, caliper, gamma-gamma density, and resistivity) from both wells (Chapter 4); coal physical and geochemical data (proximate, ultimate, forms of sulfur, ash fusion temperatures, free swelling index, apparent specific gravity, and trace element data) for both wells (Appendix 1); coal petrographic results including coal maceral composition, and vitrinite reflectance data (Chapter 5); palynological data (Chapter 6); dinocyst data (Chapter 7); coal gas desorption results (following Barker and others, 2002) for samples from USGSPA-2 (no gas was measured from samples obtained from USGS-PA-1) (Chapter 8); methane and carbon dioxide sorption data from selected samples from USGS-PA2 (Appendicies 2 and 3); Langmuir models for coal sorption of various mixtures of methane and carbon dioxide (Appendix 4); coal gas molecular and isotopic data for a mixture of 
coal gas and canister headspace gas (air) (Appendix 5); Railroad Commission of Texas Coal Exploration Registration application and approval letters with detailed location maps (Appendix 6); and digital files for geophysical logs and spread sheets (Appendix 7).

\section{Acknowledgements}

Many people contributed to the field and laboratory work associated with this project. First, we would like to thank land and mineral owners John Pilkington, Arthur McFadden, and Buddy Townson, for permission to drill on their properties. We thank Lloyd E. Morris (Director of Drilling Operations), Thomas E. Yancey (Professor of Geology), and Jennifer M. Klein and Brenda McCaleb (Graduate Students), of the Texas A\&M University Department of Geology and Geophysics for their assistance in the field and for their contributions to this study. Damaris Torres Pulliza, Dena Schmidt, and Ron Tingook (USGS student interns and contractors) and Robert W. Hook (USGS contractor) worked long hours during the drilling phase of the project. USGS employees Claire E. Aubourg, Steven M. Podwysocki, Roger E. Thomas, Woody C. Wallace, and Jason C. Willett also worked long hours during the drilling phase and helped to make the project successful. The following USGS contracted companies provided analytical services for this project: Century Geophysical Corporation (geophysical logs), Geochemical Testing (coal geochemistry), Isotech Laboratories Inc. (gas geochemistry), R.M.B. Earth Science Consultants Ltd. (coal sorption isotherms), and New Mexico Bureau of Mines and Mineral Resources, Geochronology Research Laboratory (tonstein radiometric ages; no tonstein samples collected in this study had sufficient sanidine crystal size for age determination). 


\section{References Cited}

Barker, C.E., Dallegge, T.A. and Clark, A.C., 2002, USGS Coal desorption equipment and a spreadsheet for analysis of lost and total gas from canister desorption measurements: U.S. Geological Survey Open-File Report 02-496, un-paginated. http://pubs.usgs.gov/of/2002/ofr-02-496/

SanFilipo, J.R., Barker, C.E., Stanton, R.W., Warwick, P.D., Morris, L.E., 2000a, A shallow coal-bed methane show in the Gulf Coast of Texas, indication of downdip commercial potential?: American Association of Petroleum Geologists 2000 Annual Convention Program, p. A130-A131. http://aapg.confex.com/aapg/no2000/techprogram/paper 1809.htm

SanFilipo, J.R., Warwick, P.D., Barker, C.E., Biewick, L.R.H., and Stanton, R.W., 2000b, A show of methane from shallow low-rank coal in the Gulf Coast of Texas, and its implications for basin-wide commercial potential, in Mastalerz, M., ed.: The Society for Organic Petrology, Abstracts and Program, v. 17, p. 77-78.

Warwick, P.D., Barker, C.E., SanFilipo, J.R., Morris, L.E., 2000a, Preliminary results from coal-bed methane drilling in Panola County, Texas: U.S. Geological Survey Open File Report 00-048, 30 p. http://pubs.usgs.gov/of/of00-048/

Warwick, P.D., Barker, C.E., SanFilipo, J.R., Biewick, L.R.H., 2000b, Preliminary evaluation of the coalbed methane resources of the Gulf Coastal Plain: U.S. Geological Survey Open File Report 00-143, 43 p. http://pubs.usgs.gov/of/of00$\underline{143 /}$ 
Warwick, P.D., Barker, C.E, and SanFilipo, J.R., 2002, Preliminary evaluation of the coalbed methane potential of the Gulf Coastal Plain, USA and Mexico, in Schwochow, S.D., and Nuccio, V.F. (eds.), Coalbed Methane of North America II: Rocky Mountain Association of Geologists, p. 99-107.

Warwick, P.D., SanFilipo, J.R., Barker, C.E., and Morris, L.E., 1999, Coal-bed methane in the Gulf Coastal Plain: a new frontier?: Geological Society of America Abstracts with Programs, 1999 Annual Meeting, v. 31, no. 7, p. A-386. http://rock.geosociety.org/docs/absindex/annual/1999/51995.htm 


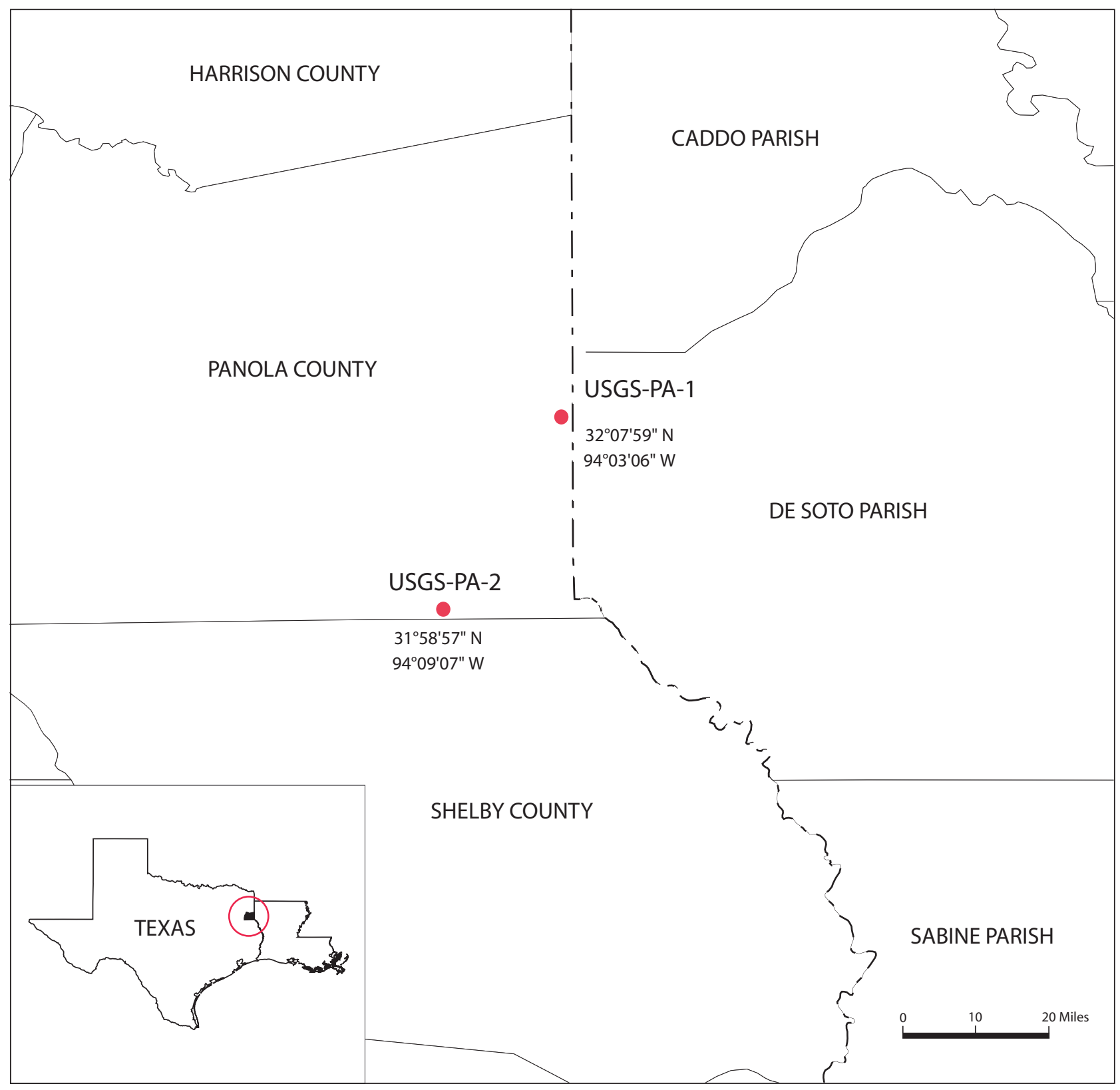

Figure 1. Locations of drill holes (red circles) in Panola County, Texas. 


\section{Chapter 2}

\section{Field core descriptions of boreholes USGS-PA-1 and USGS-PA-2}

By John R. SanFilipo', Peter D. Warwick', Ronnie Tingook ${ }^{2}$, Jennifer M. Klein ${ }^{3}$, and Brenda McCaleb

Chapter 2 of

Results of coalbed methane drilling in Panola County, Texas

Edited By Peter D. Warwick', John R. SanFilipo', Alex W. Karlsen', and Charles E. Barker²

'U.S. Geological Survey, Reston, VA

${ }^{2}$ U.S. Geological Survey, Denver, CO

${ }^{3}$ University of Texas A\&M, College Station, TX

Open-File Report 2005-1046

U.S. Department of the Interior

U.S. Geological Survey 


\section{Borehole USGS-PA-1}

Location: Arthur McFaddin Ranch, Panola Co. TX, about 0.5 mi west of the LA state line, 0.5 mi south of the intersection of county roads 467 and 463, Old Panola 7.5 ' topographic sheet.

Coordinates: lat $32^{\circ} 07^{\prime} 59.32^{\prime \prime} \mathrm{N}, 94^{\circ} 03^{\prime} 06.37^{\prime} \mathrm{W}$ (GPS)

Ground elevation: $270 \mathrm{ft}$ (estimated from topographic map)

Total depth: $380 \mathrm{ft}$

Driller: Lloyd Morris, Texas A\&M University

Drill rig: truck-mounted Mobile Drill B-53

Drilling method: Continuous wireline coring, split $10 \mathrm{ft}$ inner-tube or $5 \mathrm{ft}$ spring loaded push tube with shoe (similar to Dennison sampler)

Bit type: tungsten-carbide/diamond $\mathrm{HC} 4.75 " \mathrm{OD}, 2.5$ " core

Drilling medium: bentonite mud

Casing: none (PVC to $6 \mathrm{ft})$

Geophysical logs: Natural gamma, caliper, gamma-gamma density, resistivity

Dates drilled: 13 June 99 to 20 June 99

Rock descriptions by: J. SanFilipo, P. Warwick, R. Tingook (USGS), J. Klein, B. McCaleb (A\&M)

Remarks: Drilled soft units with $5 \mathrm{ft}$ solid push tube.

Drilled hard units and coal with $10 \mathrm{ft}$ split tube, various run lengths.

Desorbed coal 129.8 - $130.7 \mathrm{ft}$ (trace of gas) and 331.0 - 347.7 ft (no gas).

More detailed descriptions of coal beds done in laboratory settings after desorption completed can be found in Chapter 3, this volume.

\section{Abbreviations used: \\ TOR -Top of run \\ BOR - Bottom of run \\ Elog - geophysical log \\ Carb - carbonaceous}


Unit

Thickness

Number Description (primary lithology in bold)

(Depth) $\mathrm{ft}$

0.5

1. Siltstone, dark-gray, organic-rich grassy zone

2. Siltstone, sandy, very fine-grained

3. Siltstone, gray with 0.25 in. reddish lenses, top of weathering.

4. Siltstone, light-gray, 0.5 in. carbonaceous bands near top, weathering orange from 5.0 to 5.4, very fine grained sand lenses throughout, becoming more sandy towards base

5. Core loss, bottom of run (BOR), switched to $5 \mathrm{ft}$ tube

6. Core loss

6.

7. Siltstone and very fine-grained sugary sandstone laminae, gray with 2.8 scattered carbonaceous streaks, weathered from 7.5 to 9.0, BOR

0.4

8. Core loss

9. Siltstone, similar to above, light-gray with reddish weathering bands, noncalcareous

10. Siltstone, laminated as above (tidal banding?), becoming more clayrich downward, with dark-chocolate-brown bands (tidal?), BOR

11. Siltstone with light- to dark-gray clay bands, bioturbated?, a few scattered reddish weathering layers.

12. Mudstone, dark-gray, banded, bioturbated, silty, plant debris, becoming clayey at base with $1 \mathrm{~cm}$ thick carbonaceous band.

13. Claystone, dark-gray, denses, highly organic, with silty and sandy laminations and a few cm thick burrows, pollen sample PA-1-A 19.8-19.9, BOR 
14. Mudstone, dark-gray, carbonaceous, flat bedded, dense, with mm

thick silty lenses.

15. Siltstone, dark-gray, dense, hard, bioturbated, $1 \mathrm{~mm}$ thick finegrained sand flasers

16. Sandstone, medium-gray, very fine to fine-grained, soft, with sandy carbonaceous laminae, BOR

17. Sandstone, medium-gray, with dark-gray $2 \mathrm{~mm}$ mud bands, 2.0

flasered, soft...

18. Coal (plugged up long shoe on $5 \mathrm{ft}$ push tube), sample USGS-PA-1-B $\quad 0.25$ (pollen) from here.

19. Core loss in coal (elog)

1.9

20. Core loss, probably claystone (gamma), BOR, switched to 10 split tube.(30.0)

21. Core loss, probably silty claystone (gamma)

22. Claystone, medium-gray, faint silty laminae, burrowed, rooted?, sample 4.35 PA-1-C 31.9-32.0 (pollen).

23. Mudstone, faintly laminated with clay and silt $<1 \mathrm{~mm}$ thick, possibly flasered, becomes more silty below a $3 \mathrm{~cm}$ silt band at 38.7, sample PA-1-D 38.0-38.1 (pollen), BOR

24. Core loss, probably mudstone as above (aa), tube not latched?

25. Mudstone like unit 23, burrowed, grading to siltstone at base, core badly broken, BOR

26. Siltstone, medium-gray, thinly laminated, flasered, rippled?

27. Siltstone, medium-gray, very fine grained sand laminae, rippled?, becomes very sandy at base....

28. Core loss, probably silty sandstone (elog), BOR (60.0) 
29. Core loss, probably silty sandstone (elog).

30. Siltstone, medium-gray, thin faint laminae of silt, clay and very fine $\quad 6.0$ sand, flasered, rippled?, sample PA-1-2E 66.0-66.1 (pollen), BOR, switched to $5 \mathrm{ft}$ tube

31. Siltstone, muddy, top 6 in. has abundant organic laminae and specks, lower part has flat to wavy $2 \mathrm{~mm}$ silt and clay laminae, rippled, burrowed, BOR

1.0

32. Siltstone, with sandy and clayey laminations, similar to above (76.0)

33. Sandstone, very fine-grained, siltstone laminations, clay drapes, organic flecks throughout

34. Sandstone, medium-greenish-gray (glauconitic?), very fine grained, 0.5 silt and clay laminae, micaceous, BOR

35. Sandstone, same as unit 34

36. Siltstone, greenish-gray, finely laminated (tidal banding?), base appears to be a flooding surface

37. Siltstone bordering on sandstone, chocolate-brown, very organic, burrowed, sample PA-1-F 83.5-83.6 (pollen).

38. Siltstone, chocolate-brown, laminated, $2 \mathrm{~cm}$ horizontal burrows filled with white silt or greenish clay, BOR

39. Siltstone, same as unit 38, sample PA-1-G 85.3-85.4 (pollen)

40. Sandstone, medium-gray, very fine-grained, flat-bedded tidal laminae, organic lenses

41. Sandstone, greenish-gray, micaceous, laminated with sets of $1 \mathrm{~cm}$ and $\mathrm{mm}$ scale tidal banding (photo), BOR

42. Siltstone, with very fine-grained greenish-gray tidal sand laminae which may be inclined $1-2 \mathrm{deg}$, burrowed, upper $2 \mathrm{ft}$ is more sandy and less laminated than bottom, BOR 
43. Core loss, probably sandstone similar to unit 44 .

44. Sandstone, muddy, flat-bedded tidal-like laminae, carbonaceous flecks, base is more silty, core broken and compressed, sample PA-1-H

45. Sandstone, medium-gray, very fine-grained, silty, clayey, micaceous, scattered carbonaceous flecks and burrows, $3-5 \mathrm{~cm}$ sets of crosslaminae with tidal mud? drapes, BOR

46. Core loss, probably siltstone like unit 47 ....

47. Siltstone, sandy, sand very fine-grained, micaceous, organic flecks, less apparent bedding than above, no dark clay bands, becomes more $\quad 4.8$ massive and finer-grained downwards, BOR.

48. Sandstone, very fine-grained, silty, carbonaceous flecks, micaceous....(112.85)

49. Coal, brown, lignitic, entire interval sample PA-1-I (pollen).

49. Coal, brown, lignitic, entire interval sample PA-1-I (pollen)....

50. Claystone, light-gray, rooted, carbonaceous streaks

51. Siltstone, clayey

52. Sandstone, very fine grained, silty, carbonaceous flecks, burrowed?, $\quad 0.3$ BOR

53. Core loss, sandstone (elog)

54. Sandstone, fine-grained, white clay rip up clasts in lower part

55. Sandstone, with carbonaceous laminae $<1 \mathrm{~mm}$ thick, at top is a $2 \mathrm{~mm}$ whispy white clay chip that may be a tonstein.

56. Sandstone, fine- to medium-grained, soft, quartz and organic flecks, scattered clay rip-up clasts, BOR 
57. Sandstone, medium-gray, fine- to medium-grained, micaceous,

58. Shale pebble conglomerate, hard layer of rip-up clasts, photo.

59. Sandstone, medium-gray, medium- to fine-grained, soft, massive similar to unit 57, BOR

60. Core loss in sandstone (moved from BOR to reconcile e-log)

61. Sandstone, same as unit 59 , described as sharp contact with unit below but e-log indicates roof shale (lost shale and washed sand?)

62. Coal, hard, brown, lignitic, sample USGS-PA-1.1, BOR, switched to $10 \mathrm{ft}$ split tube.

Unit 62 subsampled for geochemistry after reexamination in lab:

128.00-128.15 dark olive black mudstone with coal streaks, not analyzed 128.15-128.75 dirty coal, sample USGS-PA-1.1A

128.75-129.80 coal, sample USGS-PA-1.1B

63. Coal, hard, brittle, some pre-vitrain bands, desorbed in cannister 11 (trace of gas), sample USGS-PA-1.2.

64. Coal, top is hard, brittle, slightly banded (pre-vitrain), slightly shaley, $\quad 2.1$ some thin sand laminae, more towards base, sample USGS-PA-1.3.....(132.8)

65. Coal, abundant $<1 \mathrm{~mm}$ thick sand laminae, not sampled, sharp contact with unit 66 (nb: $4.6 \mathrm{ft}$ total coal density $\log$ )

66. Claystone, chocolate-brown, very fine-grained sand laminae throughout, grading to sandy mudstone at base, sample PA-1-J (pollen) 0.9 $133.0-133.1$

67. Core loss, probably sandy claystone, BOR (switched to $5 \mathrm{ft}$ tube)

68. Claystone, grayish-brown 5YR 3/2 (chocolate-brown), mm-scale flat-bedded (i.e. horizontal, parallel, planar) fine- to very fine-grained sand laminae throughout, some possible bioturbation in places, towards base laminae increase in number and thickness to $20 \mathrm{~mm}$ sets which are slightly rippled with carb debris along bedding, pollen sample PA-1-K 138.0-138.1, BOR $(140.0)$ 
69. Core loss, probably sandy claystone.

70. Claystone similar to unit 68 , top mostly clay, base sandier.

71. Sandstone, fine-grained, some dark minerals, possible ostracode, flatlaminated with some small ripples, abundant carbonaceous laminae near base.

72. Claystone similar to unit 70, BOR

73. Core loss, probably claystone (elog), tube not latched? ( washed hole before next run and recovered $0.9 \mathrm{ft}$ broken core: chocolate mudstone and sandstone similar to unit 75).....

74. Claystone, similar to unit 72 but slightly silty, sharp contact with unit 75

75. Sandstone, fine-grained, wavy-bedded, some dark minerals, BOR......(150.0)

76. Core loss (probably sandstone)

77. Sandstone, fine-grained, mostly quartz, very muddy, some dark minerals, mica/gypsum? (altered pyrite) flakes, top foot is massive, middle contains disturbed (bioturbated?) carbonaceous laminae which grade down to slightly inclined thin parallel-bedded laminae, $20 \mathrm{~cm}$ clay band near base, base grades....

78. Mudstone, core badly broken, mostly fine-grained sandstone with clay laminae, base is very carbonaceous with leaf prints on bedding and grades into unit 79

79. Sandstone, fine-grained, with wavy carbonaceous claystone laminae, base gradational

80. Claystone, dusky-yellowish-brown $10 \mathrm{YR} 2 / 2$, top is very carbonaceous with abundant marcasite specks, a few sandstone laminae throughout, BOR

81. Core loss, probably carbonaceous claystone 
82. Claystone, chocolate-brown, carbonaceous

83. Carbonaceous shale with a few clay bands a few cm thick, sample 0.25 PA-1-L 155.7-155.8 (pollen).

84. Sandstone, medium-gray, fine-grained, soft, banded, carbonaceous streaks up to $1 \mathrm{~cm}$ thick near top and $2-5 \mathrm{~mm}$ rippled carbonaceous laminae in places

85. Sandstone, fine-grained, carb streaks throughout

86. Sandstone, greenish-gray, fine-grained, mostly quartz with some dark minerals or carbonaceous grains, BOR

87. Core loss, sandstone (elog)

88. Sandstone, light-olive-gray $5 \mathrm{Y} 6 / 1$, fine-grained, micaceous? (gypsum?), some pyrite, salt and pepper with a few percent dark minerals, mostly massive except a few wavy carbonaceous laminae at top.

89. Sandstone, light-olive-gray, fine-grained, with wavy clay laminae up to $2 \mathrm{~mm}$ thick, base is coaly, BOR

90. Core loss, sandstone (elog)

0.6

91. Sandstone, similar to unit 89 but no laminations, base grades.

92. Sandstone, with mm-scale clay laminae which increase in number towards base, a few carbonaceous laminae in middle, irregular bedding, mostly flat at top, wavy in upper middlle, flat in lower middle, and wavy at base. Appears to be soft sediment deformation (deltaic?) as opposed to tidal in origin, BOR

93. Sandstone, light-olive-gray $5 \mathrm{Y}$ 6/1, with abundant olive-gray 5Y4/1 claystone laminae, 30 - 40 pct clay, 60 - 70 pct sand, irregular bedding, looks like soft sediment deformation, not rythmic, but possibly some bi-directional ripple bedding that may be tidal in origin, BOR. 
94. Interlaminated claystone and sandstone similar to unit 93, grading to flat-bedded at about 175.3. Percent clay increases in the middle (about 90 pct clay at $178 \mathrm{ft}$ ) then becomes sandier at base (40 pct sand). from about $179 \mathrm{ft}$ down bedding is rythmic showing possible tidal couplets $10-15 \mathrm{~mm}$ thick, $1 \mathrm{~cm}$ siderite band at 178.9, sample PA-1-M 5.0 179.9-180.0 (pollen), BOR (switched to $10 \mathrm{ft}$ split tube).

95. Interlaminated claystone and sandstone like unit 94, mostly sand.......(180.4)

96. Olive gray claystone ( 90 pct) with 10 pct light olive gray fine-grained 1.6 sandstone similar to unit 94.

0.8

97. Core loss in coal (elog).

98. Coal, dirty, fissile, very pyritic, abundant clay lenses, sample PA-1-N $\quad 0.8$ (pollen) from this interval (grab).

99. Very carbonaceous claystone, dark-brown, base grades, sample PA-1-O 183.7-183.8 (pollen).

100. Claystone, chocolate-brown, moderately carbonaceous, massive, root traces, base grades, sample PA-1-P 184.7-184.8 (pollen)

101. Interlaminated sandstone and claystone like unit 95.

102. Sandstone, gray, fine-grained, massive.

103. Core loss, sandstone like unit 102 (elog)

104. Claystone, chocolate-brown.

105. Sandstone, similar to unit 102, carbonaceous streaks, BOR (switched 0.25 to $5 \mathrm{ft}$ solid tube)

0.5

106. Core loss, probably sandstone similar to unit 102 .

107. Siltstone, sandy, sand is very fine grained, $5 \mathrm{~mm} \mathrm{mud/clay} \mathrm{laminae,}$ rippled, burrowed, tidal banding, flasered. 
108. Mudstone, consisting of interbedded $1 \mathrm{~cm}$ siltstone and claystone

bands that are wavey to flaser bedded, BOR

109. Mudstone, consists of $10 \mathrm{~mm}$ clay drapes? (drilling artifacts?) that are rhythmically paired with similarly thick sets of interlaminated very fine grained sand and clay, laminae $<1 \mathrm{~mm}$ thick, sample PA-1-Q 198.0-198.1 (pollen), BOR

110. Core loss, probably claystone (elog).

111. Mudstone similar to unit 109, with chocolate-brown silty clay bands that are $1-3 \mathrm{~cm}$ thick rhythmically coupled with subequal sets of irregularly laminated sand and clay. Although these appear to be very rhythmic (e.g.13 clay band/laminar sets were counted from $204-205 \mathrm{ft}$ ), they need to be reexamined for possible drilling mud contamination as the core appeared to be spun at regular intervals, BOR................(205.0)

112. Claystone, chocolate-brown, with very fine grained sandstone laminae 0.5 that are flat- to slightly wavy-bedded, 70 pet clay, 30 pet sand.

113. Core loss, probably claystone similar to unit 112

114. Claystone, similar to unit 112 except more clayey at top, sample 0.9 PA-1-R 209.5-209.6 (pollen), BOR

115. Core loss, probably claystone (elog) .$(210.7)$

116. Siltstone, with mm-scale sand laminations, tidal banded.

117. Shale, carbonaceous, silty.

118. Sandstone, with wavey-bedded silt and carbonaceous lamine, 0.75 slightly burrowed

119. Sandstone, medium-gray, fine- to medium-grained, micaceous, 2.5 black minerals, soft, faintly laminated, flat-bedded

120. Sandstone, carbonaceous silt laminations, flasered, tidal, BOR (215.0) 
121. Core loss in sandstone (elog)

1.0

122. Sandstone, medium-gray, fine-grained, micaceous, flat-bedded ...

123. Sandstone, same as unit 120 , rippled

124. Siltstone, chocolate-brown, laminated, slightly burrowed, clayey and carbonaceous near base

125. Claystone, with silty stringers, base carbonaceous, dense, hard 1.0 to drill, BOR (switched to $10 \mathrm{ft}$ split tube)

126. Core loss, probably siltstone (gamma log)

127. Claystone, carbonaceous, grayish-brown 5YR 3/2 (chocolate) with darker bands (dusky-brown 5YR 2/2), silty, dense, compact, homogenous except for color-banding and streaks of very fine-grained quartz sand $<1 \mathrm{~mm}$ thick that are abundant throughout, sand is very well sorted (paralic?), $\quad 7.3$

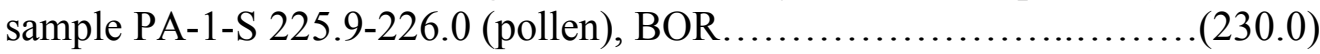

128. Carbonaceous claystone same as unit 127 (230.4)

1.1

129. Core loss, probably carb claystone (elog)

130. Carbonaceous claystone similar to unit 127 , sand laminae more abundant in the middle part.

131. Carbonaceous siltstone, dark-yellowish-brown 10 YR 4/2, hard 0.1 dense, possibly sideritic (no density kick ?).

132. Carbonaceous claystone same as unit 127

133. Carbonaceous siltstone similar to unit 131 (239.4)

134. Carbonaceous claystone same as unit 127, sample PA-1-T 239.8- 0.6 239.9 (pollen), BOR 
135. Core loss, carbonaceous claystone and siltstone as above (elog)

136. Carbonaceous siltstone, similar to unit 131, but sandy, not

sideritic

137. Core loss, carbonaceous claystone as above (elog), repositioned

from TOR to match elog.

138. Core loss in sandstone (elog, repositioned from TOR), BOR

10.0

139. Core loss in sandstone (elog), BOR (switched to $5 \mathrm{ft}$ solid tube)

140. Core loss in sandstone (elog)

141. Sandstone, fine - medium grained, salt and pepper, a few pct dark minerals, micaceous, subrounded, fairly mature looking, no bedding evident but very unconsolidated, BOR (switched to split tube?)

142. Sandstone, medium-grained, salt and pepper, 2 pct dark minerals 3.5 subrounded, clean, mature, faint bedding, BOR (switched to $5 \mathrm{ft}$ tube)...(268.5)

0.4

143. Core loss, probably sandstone like unit 142

144. Sandstone, same as unit 142, sharp contact with unit 145.

145. Claystone, medium-dark-gray N 4 to olive-gray $5 \mathrm{Y} 4 / 1$, thin $(<1 \mathrm{~mm})$ laminae of silt to very fine-grained sandstone, sand is quartz with some possible clay minerals (ash?), laminae are flat, subparallel, with a few ripples, BOR.

146. Claystone, same as unit 145 , base grades

147. Sandstone, olive-gray 5 Y 4/1, fine-grained, very muddy, micaceous?, scattered pyrite grains, abundant coaly debris at base, possibly

fines up.... 
148. Core loss, sandstone (elog), probably coarser than unit 147, BOR

149. Core loss, sandstone (elog)

150. Sandstone, similar to unit 147 , base is coaly and grades into unit $151 \ldots$ (275.7)

151. Mudstone, olive-gray 5Y 4/1, subequal amounts of silt and very finegrained sand, massive, rooted, vertical burrows filled with sand, hard compact, BOR

152. Mudstone, same as unit 151 , base grades

153. Sandstone, olive-gray, fine-grained, muddy, fines up, homogenous, $\quad 1.4$ probably bioturbated, coaly streaks at base.

154. Core loss, sandstone (elog), BOR

155. Sandstone, light-olive-gray $5 \mathrm{Y} 6 / 1$, fine-grained, salt and pepper, 1-2 pct dark minerals, faint bedding, friable, nodular bands of siderite? in places

156. Sandstone same as unit $155,15 \mathrm{~mm}$ siderite band at $290.25 \mathrm{ft}$

157. Siderite, hard, plugged core catcher

158. Core loss, probably mudstone similar to unit 160 , density log indicates possibly sideritic, BOR

159. Core loss, probably mudstone, density log suggests sideritic....

160. Mudstone, grading downward from olive-black 5Y 2/1 mudstone consisting of an equal mix of clay, silt, and very fine to fine-grained sand, to greenish-black 5GY 2/1 siltstone to dusky yellowish brown 10 YR 2/2 sandy claystone, faintly laminated throughout, base grades, density log suggests most of unit is sideritic, sample PA-1-U (pollen) 297.9-298.0 
161. Carbonaceous claystone, dusky-brown 5YR 2/2, abundant pyritized

162. Core loss, coaly shale (elog), repositioned from BOR.

163. Carbonaceous claystone, similar to unit 161 , sub-mm-scale sandy laminations.....

164. Siltstone, olive-black $5 Y$ 2/1, with approximately 40 pct interlaminated sandstone, sand is very fine-grained, clean, subangular, silt laminations 1- to $1+\mathrm{mm}$ thick, sand $<1 \mathrm{~mm}$, mostly flat-bedded with some pseudo- $\quad 1.6$ flasers and ripples, not bioturbated.

165. Core loss, probably interlaminated siltstone and sandstone similar to unit 164 , BOR (switched to $10 \mathrm{ft}$ split tube for next $5 \mathrm{ft}$ run)

166. Core loss, probably interlaminated siltstone and sandstone as above $\quad 5.0$ (elog), BOR (switched to solid tube and fished $1 \mathrm{ft}$ similar to unit 164).(310.0)

167. Core loss, interlaminated siltstone and sandstone

168. Interlaminated clayey siltstone and sandstone, similar to unit 164 , but sandstone contains more $(\sim 3 \%)$ dark minerals, mostly flat-bedded, with a few disturbed zones and coaly streaks, disturbed zones are often subjacent to coaly streaks (storm surges? - no obvious bioturbation), towards base 4.9 lutaceous layers are thicker $(<2 \mathrm{~mm})$ and more carbonaceous

169. Interlaminated clayey siltstone and very fine-grained sandstone, similar to above, but very regular couplets of 1-mm-thick siltstone laminations and sub-mm sandstone laminations, sample PA-1-V 318.0-318.1 (pollen), BOR

170. Interlaminated siltstone and sandstone same as unit 169 (excess protruding from shoe from last run).

171. Core loss, interlaminated siltstone and sandstone (elog)

172. Interlaminated siltstone and sandstone like unit 169 , abundant coaly 0.7 fragments at base, BOR

173. Core loss, interlaminated siltstone and sandstone (elog), $0.4 \mathrm{ft}$ 
174. Core loss, interlaminated sandstone and subordinate siltstone (elog)...(329.6)

175. Sandstone with subordinate interlaminated siltstone, similar to unit $\quad 0.4$ 169 , recovered from next run, BOR.

176. Interlaminated siltstone and sandstone like unit 169 , base is less sandy and grades into unit 177, sample PA-1-W (pollen) 330.5-330.6, (before run from 330 - 335 inner tube would not latch; tube got stuck while retrieving, had to cut cable and trip out, recovering $0.4 \mathrm{ft}$ in unit 173. Did a run from 330 - 331 with long shoe and recovered $1.4 \mathrm{ft}$, units $175-178$ )

177. Carbonaceous shale, dusky-brown 5YR 2/2

178. Coal, dirty, brownish-black 5YR 2/1, broken core recovered from shoe, BOR (switched to $10 \mathrm{ft}$ split tube for short runs in coal).

179. Coal, with (reworked?) tonstein from 331.25 - 331.50 (Photo link). Coal was not described in order to be immediately sealed in desorption cannisters. Samples generally released no gas or absorbed head space gas and did so for several hours. Coal was rebagged on site for shipment to Reston and subsequent analysis as follows: USGS-PA-1.4 (331.0-334.0 ft, minus tonstein plus 0.10 coal $331.25-331.50$, sample USGS-PA-1.4T), USGSPA-1.5 (334.0-337.0), USGS-PA-1.6 (337.0-340.0), USGS-PA-1.7 (340.0343.0), USGS-PA-1.8 (343.0-346.0), USGS-PA-1.9 (346.0-347.7). 100 pct core recovery confirmed by elog. Coal was not described in detail before rebagging, but more detailed descriptions made in Reston occur in Chapter 3 of this volume (see cover sheet). BOR's at 335, $340,345 \mathrm{ft}$, base grades

180. Coal, dirty, dusky-brown 5YR 2/2 to brownish-black 5YR 2/1, plant 0.1 impressions along bedding, not desorbed, base grades

181. Claystone, carbonaceous, dusky-brown 5YR 2/2, abundant coalified $\quad 0.3$ plant debris along bedding, base grades

182. Core loss, claystone (elog), repositioned from unit 184 field description.

183. Siltstone, olive-gray 5 Y 4/1, clayey, with slightly irregular very finegrained sandstone laminations $<1 \mathrm{~mm}$ thick, siltstone laminations $<5 \mathrm{~mm}$. 
183. Core loss, siltstone (elog)

184. Interlaminated siltstone and sandstone like unit 183, subparallel $\quad 0.3$ bedding, possibly some low-angle planar crossbedding, BOR

185. Claystone, dark-gray, laminated

186. Sandstone, very fine grained, interlaminated with clayey and silty carbonaceous layers, rippled with some cross-bedding

187. Siltstone, interlaminated with very fine-grained sandstone and claystone, flaser-type bedding, some burrows, laminae a few $\mathrm{mm}$ thick, rippled in places, BOR

188. Sandstone (50 pct), very fine-grained, with interlaminated olive-gray 0.5 clayey siltstone, flat parallel mm-scale laminations....

189. Sandstone with interlaminated siltstone, similar to unit 188 , but bedding is more irregular, psuedo flasers, sandstone laminations are up to $10 \mathrm{~mm}$ thick, a few carbonaceous laminae

190. Sandstone, very fine-grained, olive gray 5 Y 4/1, top massive, base faintly bedded, a few pct dark minerals, micaceous, base grades...

191. Sandstone, very fine-grained, with slightly irregular olive-gray siltstone laminations, 70 pct sand, at base are some pseudo flasers, possible ripples, possible horizontal burrows, BOR

192. Core loss, silty sandstone (elog).

193. Sandstone with interlaminated siltstone, similar to unit 191 except bedding is flat subparallel to slightly disturbed, sandstone layers up to $\quad 3.0$ $30+\mathrm{mm}$, some carbonaceous layers.

194. Sandstone, light-olive-gray 5Y 6/1 to greenish-gray 5GY 6/1, massive 1.3 to faintly bedded, few pct dark minerals and mica.

195. Siltstone (60 pct), olive-gray, with flat-bedded sandstone laminations $\quad 0.5$ as above, middle part more sandy, BOR

196. Interlaminated siltstone and sandstone similar to unit 195 (365.2) 
198. Interlaminated siltstone and sandstone similar to unit 195, flat

199. Sandstone, light-olive-gray, similar to unit 194, BOR

200. Sandstone, similar to unit 194, silty matrix, some silty laminations at base

201. Sandstone, fine-grained, sideritic cement, very hard, very heavy, micaceous, plugged the shoe.

202. Core loss, sideritic sandstone (thickness from density log)

203. Core loss, lithology undetermined (below gamma/resistivity TD), BOR

204. Core loss, lithology undetermined

205. Sandstone, dark-gray N3 to olive-gray $5 Y$ 4/1, very fine-grained, silty, burrows, wavy laminations throughout, in places bedding disrupted by bioturbation, grades into unit 206

206. Sandstone, light-olive-gray $5 \mathrm{Y} 6 / 1$, low-angle cross-bed sets $3 \mathrm{~cm}$

0.9 thick 


\section{Borehole USGS-PA-2}

Location: John Pilkington Ranch, Panola Co. TX, about 0.3 mi north of the Shelby Co. line and $8 \mathrm{mi}$ west of the LA state line, $0.28 \mathrm{mi}$ due SE of the intersection of county roads 430 and 439 , Tenaha East 7.5 ' topographic sheet

Coordinates: lat $31^{\circ} 58^{\prime} 57.03^{\prime \prime} \mathrm{N}, 94^{\circ} 09^{\prime} 07.38^{\prime \prime} \mathrm{W}$ (GPS)

Ground elevation: $253 \mathrm{ft}$. (estimated from topographic map)

Total depth: $400 \mathrm{ft}$.

Driller: Lloyd Morris, Texas A\&M University

Drill rig: truck-mounted Mobile Drill

Drilling method: Continuous wireline coring, split $10 \mathrm{ft}$ inner-tube or $5 \mathrm{ft}$ spring loaded push tube with shoe (similar to Dennison sampler)

Bit type: tungsten-carbide/diamond $\mathrm{HC} 4.75$ " OD, 2.5" core

Drilling medium: bentonite mud

Casing: none (PVC to $6 \mathrm{ft})$

Geophysical logs: Natural gamma, caliper, gamma-gamma density, resistivity

Dates drilled: 21 June 99 to 28 June 99

Rock descriptions by: J. SanFilipo, P. Warwick, D. Torres Pulliza, W. Wallace, R. Tingook (USGS)

Remarks: Drilled soft units with $5 \mathrm{ft}$ solid push tube Drilled hard units and coal with $10 \mathrm{ft}$ split tube, various run lengths Desorbed coal from 355 to 373 feet with measurable but small quantities of gas recovered. Desorption was completed in the field by 6/29/99. More detailed descriptions of coal beds done in laboratory settings after desorption completed can be found in Chapter 3, this volume.

\footnotetext{
Abbreviations used:

TOR -Top of run

BOR - Bottom of run

Elog - geophysical log

vfg - very fine-grained

carb - carbonaceous
} 
Unit

Thickness

Number

Description (primary lithology in bold)

(Depth) ft.

0.6

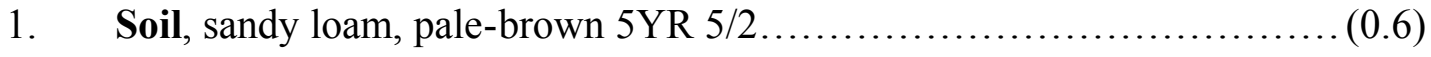

2. Soil, clay, mottled moderate-reddish brown 10R 4/6 to dark-yellowish- $\quad 1.4$ orange 10 YR 6/6, Bottom of Run (BOR).

3. Soil, loamy, pale brown sand-like unit 1 grading into mottled clay- $\quad 0.4$ like unit 2 , base grades........................................... (2.4)

4. Sandstone, dark-yellowish-orange, very fine-grained, with 1.1 yellowish-gray 5 Y $7 / 2$ clay matrix, weathered.

5. Sandstone, pale-yellowish-orange $10 \mathrm{YR} 8 / 6$, very fine-grained, salt 0.5 and pepper, a few pct dark minerals, weathered, BOR

6. Claystone, pale-yellowish-brown 10YR 6/2, with interlaminated weathered sandstone that is dark yellowish orange, a few pct dark minerals, micaceous

7. Sandstone, grayish-orange $10 \mathrm{YR} 7 / 4$, otherwise as above, slightly weathered, BOR (switched from augur coring to $5 \mathrm{ft}$ push tube)

8. Core loss.

9. Sandstone, moderate-yellowish-brown 10YR 5/4, mottled with dark to pale-yellowish-orange streaks and pale-yellow clay bands, weathered, 3.5 sand is very fine grained, clayey, salt and pepper, BOR

10. Core loss

11. Sandstone, pale-yellowish-brown 10 YR 6/2, very fine-grained, clayey, 2.5 appears massive but base grades, hematite band at $11 \mathrm{ft} \mathrm{a}$ few mm thick (12.9)

12. Interlaminated pale-yellowish-orange sandstone and pale-yellowishbrown claystone, weathered, sandstone is very fine-grained, salt and pepper, laminae are $1-2 \mathrm{~mm}$ thick, sharp contact with unit 13 
13. Sandstone, pale-yellowish-brown, very fine-grained, salt and pepper, $\quad 0.4$ appears somewhat less weathered, BOR

14. Sandstone, similar to unit 13 , but more weathered, a few dark-

yellowish-orange streaks, clayey....

15. Core loss, clayey sandstone (elog)

0.5

16. Sandstone, pale-yellowish-orange, similar to unit 14, BOR

1.0

17. Core loss, sandy claystone? (elog)

18. Clayey sandstone similar to unit 14 , a few $\mathrm{cm}$ siderite at $22.7 \mathrm{ft}$

19. Core loss, clayey sandstone? (elog)

0.7

20. Sandstone similar to unit 14 .

21. Siderite?, very hard

22. Sandstone, very fine-grained, pale-yellowish-brown, salt and pepper, micaceous, slightly weathered, similar to above but with carbonaceous $\quad 1.8$ cross-laminations $<1 \mathrm{~mm}$ thick, BOR

0.8

23. Core loss, clayey sandstone? (elog)

24. Sandstone, very fine-grained, pale-yellowish-brown with a few dark- $\quad 4.2$ yellowish-orange streaks, some weathered carbonaceous laminae, BOR (35.0)

25. Core loss, sandstone (elog)

26. Sandstone, very fine-grained, similar to above, drilling too fast to 3.0 describe in detail, BOR

27. Core loss in sandstone (elog) 
29. Core loss in sandstone (elog), BOR

30. Sandstone, similar to above, top is dark-yellowish-orange and still very weathered, sharp contact with unit 31

31. Claystone, brownish-gray 5YR 4/1, moderately carbonaceous, silty, massive, top is weathered dark-yellowish-orange (possibly siderite or weathered coal), base grades, sample PA-2-A 52.9-53.0 (pollen).

32. Sandstone, pale-yellowish-brown, very fine-grained, salt and pepper, $\quad 2.0$ coal streaks at base, BOR

33. Core loss in sandstone (elog)

34. Sandstone, light-olive-gray 5 Y $5 / 2$ with a few dark-yellowish-orange streaks, base of weathering about $57 \mathrm{ft}$, salt and pepper with abundant dark minerals, a few oxidized carbonaceous streaks, BOR

35. Sandstone, light-olive-gray, very fine-grained grading to fine-grained in places, clean, salt and pepper, abundant ( 2 pct) dark minerals, some quartz grains are watery clear, slightly inclined carbonaceous $\quad 5.0$ laminations from 61.4 to 64.8 , otherwise massive, unweathered, BOR... (65.0)

36. Core loss, sandstone (elog)

37. Sandstone, similar to unit 35, grains are subangular, watery clear quartz grains throughout, faint crossbedding throughout - most obvious on $\quad 4.6$ carbonaceous layers, BOR..................................... (70.0)

38. Core loss in sandstone (elog)

39. Sandstone like unit 37

40. Siderite, may have come from higher up, BOR $(75.0)$

41. Core loss in sandstone (elog), BOR (80.0) 
42. Sandstone like unit 37 , coaly layer from $83.1-83.2$, BOR

43. Sandstone like unit $37,10 \mathrm{~cm}$ siderite at 85.2 .

44. Core loss in sandstone (elog)

45. Sandstone like unit 37

46. Sandstone, coaly, with $10 \mathrm{~cm}$ siderite layer at 89.9 , very coaly below 0.3 that, BOR

47. Sandstone, light-olive-gray 5 Y 5/2, medium-grained, angular to subangular watery clear quartz, some doubly terminated, $2-3$ pct dark minerals, some basaltic hornblende, coaly streaks top and base (nb: due to very fast penetration rate sand from $40-90 \mathrm{ft}$ could not be adequately described on site; grain size may be coarser than vfg, on gamma log looks like first increase came at about $76 \mathrm{ft}$ )

48. Core loss, sandstone, repositioned from TOR to match elog, base is

49. Core loss, siderite? (elog).

50. Sandstone like unit 47 , sharp contact with unit 51

51. Coal, base grades, sample PA-2-B (pollen).

52. Claystone, light-olive-gray, sandy, sharp contact with unit 53

53. Claystone, yellowish-gray 5 Y 8/1, tonstein?, siderite? (some fizzing $\quad 0.1$ with 10 pct HCL), sample PA-2-R1, sharp contact with unit 54

54. Sandstone, light-olive-gray, very fine-grained, interlaminated with olivegray $5 \mathrm{Y} 4 / 1$ silty claystone, bedding is flat to slightly inclined, planar to slightly wavy, $8 \mathrm{~cm}$ yellowish gray clay band at 98.3 (tonstein?), sample PA-2-C 97.8-98.0 (pollen/dinocystss), BOR $(100.0)$ 
55. Interlaminated sandstone and claystone similar to unit 54, flat- to

ripple-bedded, sharp contact with unit 56

56. Yellowish-gray claystone like unit 53 (tonstein?), (Photo) very clean, 0.08

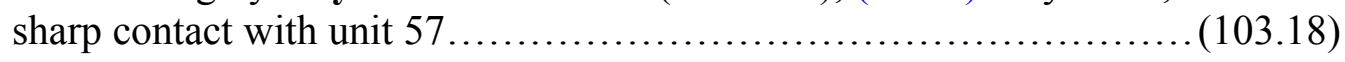

57. Interlaminated sandstone and claystone similar to unit 55, base is more sandy (registers to $104 \mathrm{ft}$ on gamma log?), a few yellowishgray claystone layers like unit 56 but contacts less sharp, BOR.

58. Claystone, olive-gray $5 \mathrm{Y} 4 / 1$ with light-brownish- gray bands in places, silty, interlaminated with light-olive-gray very fine grained sandstone as above, 70 pct clay, top(?) and base grade, sample PA-2-D (pollen) 107.9-108.0.

59. Sandstone interlaminated with claystone, similar to unit 58 but about 60 pct sand (contact picked from elog), BOR.

60. Mudstone, subequal silty claystone and interlaminated very finegrained sandstone similar to above, sharp contact with unit 61

0.1

61. Claystone, yellowish-gray, very hard, probably sideritic

62. Core loss, siderite, repositioned from TOR to match elog

63. Claystone, with sandstone, lamiae, very disturbed bedding, probably a small (intraformational?) fault (Photo)

64. Mudstone similar to unit 60, base carbonaceous, BOR.

65. Carbonaceous claystone, greenish-black 5GY 2/1, sample PA-2-E 115.2-115.3 (pollen)

66. Sandstone, light-olive-gray, very fine grained, with silty olive-gray 0.4 claystone laminations $1-2 \mathrm{~mm}$ thick, base grades

67. Sandstone, light-olive-gray with some greenish-black carbonaceous zones, somewhat dirty, consisting of very fine to fine-grained quartz with abundant dark minerals, very hard, sideritic cement, possible lithic fragments although these may actually be recrystallized zones, good density kick. 
68. Core loss, probably sandstone with interlaminated claystone similar

69. Core loss, probably sandstone and interlaminated claystone (elog).

70. Sandstone, light-olive-gray, fine-grained, with light brownish gray 5YR 6/1 claystone laminae about $1 \mathrm{~mm}$ thick, a few sub-mm carbonaceous laminae throughout, some cross-bedding?, top is clean, base more clayey, BOR

71. Sandstone, light-olive-gray, very fine-grained, sugary, $\sim 2$ pct dark minerals, interlaminated with dusky yellowish brown 10YR $2 / 2$ clayey siltstone, sandstone laminae $<1$ to $7 \mathrm{~mm}$ thick, slst $<1 \mathrm{~mm}, 60-70$ pct sand, flat- to wavy bedded

72. Core loss, probably sandy siltstone (elog, moved from TOR)

73. Siltstone, olive-gray $5 \mathrm{Y} 4 / 1$ to dark-greenish-gray $5 \mathrm{GY} 4 / 1$, clayey, has sandstone laminae $<1 \mathrm{~mm}$ thick regularly coupled with $5 \mathrm{~mm}$ siltstone laminae, BOR, this was excess recovered in next run

74. Siltstone similar to unit 73, top is rythmically bedded, base is colorbanded but more massive and less sandy, sample PA-2-F (pollen) 134.0-134.2, BOR (switched to split tube).

75. Siltstone, dark-gray, laminated, scattered burrows, becomes more carbonaceous and black towards base...

76. Carbonaceous shale, dark-gray, silty, base grades, sample PA-2-G 137.9-138.0 (pollen)

77. Coal, black, blocky, cleated, base grades (elog coal thickness $0.8 \mathrm{ft}$ ), $\quad 0.4$ sample PA-2-H 138.2-138.4 (pollen)

78. Carbonaceous shale, dark-gray, plant debris, large stems and leaves, $\quad 1.6$ base grades, sample PA-2-I 140-140.2 (pollen).

79. Siltstone, dark-gray, laminated

80. Siltstone, coaly streaks, roots 
81. Core loss, probably very fine-grained sandstone with interlaminated 2.5 siltstone as above, BOR (swiched to $5 \mathrm{ft}$ tube?)..................... (145.0)

82. Core loss, probably sandstone like unit 83 (elog).

83. Sandstone, medium-gray, very fine-grained, with dark minerals, mica, and organic debris, small cross beds and mm-scale clay lenses in top part, bottom part is more silty and dense, BOR

84. Core loss, probably very fine-grained sandstone with interlaminated 2.3 siltstone similar to unit 85 (elog).

85 Sandstone, olive-gray $5 \mathrm{Y} 4 / 1$, very fine-grained, silty, thin $(<1 \mathrm{~mm})$ siltstone laminae throughout, at 154.2 laminae are inclined, near base some are carbonaceous, BOR

86. Sandstone and interlaminated siltstone similar to unit 85 , top is sandier, middle part is rippled, base is more clayey, with lutaceous laminae up to 1.8 $5 \mathrm{~mm}$ thick

87. Core loss, probably sandstone similar to unit $85, \mathrm{BOR}$

88. Interlaminated sandstone and siltstone similar to unit 85

89. Carbonaceous claystone, brownish-black 5YR 2/1 to greenish-black 0.4 5GY 2/1, plugged shoe, sample PA-2-J (pollen).

90. Core loss, carbonaceous claystone (elog), 0.8 loss described as from 0.3 TOR in field repositioned to match unit 89 to elog.

91. Core loss, interlaminated sandstone and siltstone as above, possibly more sandy (elog), BOR

92 Core loss, interlaminated sandstone and siltstone as above.

93. Sandstone, light-brownish-gray with light olive gray mottling, very finegrained, silty, top is massive to faintly bedded, base shows distinct (climbing?) ripples that enhance mottling, BOR

94. Ripple-bedded sandstone, same as base of unit 93 (170.8) 
95. Core loss, probably sandstone similar to unit 94, contact with unit

96. Mudstone, sandy, clayey siltstone, olive-black 5Y2/1, faintly bedded abundant coaly debris on bedding, some sandy laminations, micaceous?, sharp contact with unit 97, some light-brown friable sand in sharp contact at top appears dropped from prior run

97. Sandstone, very fine to fine-grained, dirty, micaceous, abundant dark minerals and tan lithic fragments, well-indurated, faint bedding at base grades into unit 98

98. Siltstone, brownish-black 5YR 2/1 (chocolate), mostly massive, a few 1.7 very fine grained sand laminae, base grades....

99. Siltstone, olive-gray $5 \mathrm{Y} 4 / 1$, with very fine grained sand streaks and flasers

100. Core loss, clayey siltstone (elog), BOR

101. Siltstone, olive-gray, with interlaminated light olive gray very finegrained sandstone (5Y 6/1?), flat to slightly disturbed bedding, sub-mm scale laminations

102. Core loss, probably interlaminated siltstone and sandstone similar to units 99 and 101, BOR (tube not latching?).

103. Siltstone, similar to unit 101, flat-bedded, silt laminae are several $\mathrm{mm} \quad 3.0$ thick, sand $<1 \mathrm{~mm}$

104. Core loss, claystone? (elog), shoe plugged, stopped run short, BOR (switched to $10 \mathrm{ft}$ split tube)

105. Siltstone like unit 103 , slightly sandier, badly broken core, may be 0.5 out of place, tube probably did not latch

106. Core loss, interlaminated siltstone and sandstone (elog), BOR, tube would not latch for next run and could not be retrieved, pulled rods and switched to $5 \mathrm{ft}$ solid tube, redrilled 190-195, again no recovery.

107. Core loss, interlaminated siltstone and sandstone (elog)

108. Siltstone, olive-gray, with very disturbed sand laminations, may be 0.5 disrupted by drilling problems, but lithology ok on elog.... 
109. Sandstone, olive-gray, fine- to very fine-grained, silty, very bioturbated, 1.4 no obvious bedding, coal spars at 196.6-196.7, sharp contact at base....(196.9)

110. Sandstone, light-olive-gray, very fine-grained, salt and pepper, $2-3$ pct 3.1 dark minerals, micaceous, massive, BOR

111. Sandstone, light-olive-gray, very fine-grained, micaceous, sub-mm 0.3 scale carbonaceous laminae, flat-bedded, in place?

112. Sandstone, similar to unit 110 except some faint bedding. (201.25)

113. Sandstone, mottled: light-olive-gray, white, brownish-black, very finegrained, flat-bedded, coaly fragments on laminae, calcareous (fizzes $\quad 0.05$ readily), very hard (plugged shoe), sharp contact with unit $114 \ldots \ldots \ldots .(201.30)$

114. Siltstone with interlaminated very fine-grained sandstone, soft, badly 0.3 broken (pushed from shoe), looks out of place on elog.

115. Calcareous sandstone similar to unit 113 , except high angle planar cross-bed sets at top scouring out flat laminar beds at base, no coal fragments observed, BOR, switched to $10 \mathrm{ft}$ split tube.

116. Calcareous sandstone, flat-bedded, no coal fragments, (nb: units 113, 115,116 , fizz readily without powdering and are thus presumed to be 0.8 cemented by calcite, but high density kick may indicate high $\mathrm{Fe} / \mathrm{Mg}) \ldots(202.6)$

117. Core loss, probably interlaminated siltstone and sandstone, more sandy than unit 118 (elog)

118. Siltstone, olive-black 5 Y $2 / 1$ to olive-gray 5 Y $4 / 1$, with very finegrained sandstone laminations, core badly broken

118. Calcareous sandstone, flat to disturbed bedding, some cross-beds, very hard, cone-in-cone structures at several places, no coal frags.

119. Core loss, calcareous sandstone (elog), repositioned from unit 117 1.4 to match elog....

0.8

120. Core loss, sandstone similar to unit 121 (elog) (209.8)

121. Sandstone, olive-gray, fine- to very fine-grained, silty, very bioturbated, BOR (switched to split spoon). (210.0) 
122. Sandstone, light-olive-gray, very fine-grained, finely bedded, probably bioturbated, sharp contact with unit 123 .

123. Sandstone, fine-grained, very dirty, about 5 pct dark minerals, no coal spars, hard, heavy, does not effervesce with HCL, probably sideritic cement, BOR (switched to $10 \mathrm{ft}$ split tube)

124. Sandstone, light-olive-gray mottled with iron staining, fine-grained, disturbed bedding, generally hard but soft and uncemented in places, slight HCL effervescence if powdered, sideritic and/or calcite cement...(217.3)

125. Core loss, probably sideritic sandstone as above (elog)

126. Sandstone like unit 124 , BOR

127. Sandstone, olive-gray, very fine-grained, muddy, very bioturbated, scattered coal spars, well-indurated but not cemented, base grades

128. Sandstone, fine- to very fine-grained, siltier than unit 127 , siderite? band at top, sand is in lenses, well-indurated but not cemented, sharp contact with unit 129

129. Sandstone, fine-grained, dirty matrix, more dark minerals and coal spars than above, hard, no fizz, siderite? cement, bedding obscured by coring 0.5 grooves.

130. Core loss, probably siltstone similar to unit 131 (elog)

131. Siltstone, olive-gray to brownish-gray, massive, a few very finegrained sand lenses, BOR (tube stuck, pulled rods before next run)

132. Siltstone, dusky-yellowish-brown 10YR $2 / 2$ to brownish-black 5 YR 2/1, moderately carbonaceous, scattered horizontal sand-filled burrows, abundant pyritized plant debris on bedding planes but appears massive, $\quad 9.9$ compact, well-indurated, base grades.

133. Siltstone, similar to unit 132 , but with a few very fine to fine-grained 0.1 sand laminae that are disturbed, possibly by core being spun, BOR......(240.0)

134. Siltstone, same as unit 133 , excess from last run $(240.2)$ 
135. Sandstone, olive-gray $5 \mathrm{Y} 4 / 1$, very fine to fine-grained, subrounded, $\quad 4.8$ muddy, $<1$ pct dark minerals, some coal spars, very bioturbated, BOR..(245.0)

0.1

136. Core loss in sandstone (elog)

137. Sandstone, light-olive-gray 5 Y $6 / 1$, fine-grained, subrounded, mostly massive but a few clayey layers and thin coaly laminae throughout, a few carbonaceous laminae at base, top half bioturbated, sharp contact with unit 138

138. Siltstone, olive-black, 5 Y 2/1 (chocolate), moderately carbonaceous, sub- $\mathrm{mm}$ scale sandstone laminae throughout, sand is very fine grained, $\quad 0.2$ sugary, micaceous, sample PA-2-K 249.9-250.0 (pollen), BOR.........(250.0)

139. Siltstone, similar to unit 138 , but some sandstone laminae are up to several $\mathrm{mm}$ thick and show (internal?) scouring, base is more sandy but contact with unit 140 is sharp

140. Sandstone, light-olive-gray, very fine-grained, with watery clear quartz, 0.5 a few percent dark minerals, micaceous.

141. Coal, light splintery (fusain?), some previtrain bands, sample 0.2 PA-2-L 251.9-252.1 (pollen)

142. Core loss in coal (elog), repositioned from 251.8-253.5 to reconcile elog, 1.7 BOR (run stopped short due to coal).

143. Core loss, probably dirty coal (elog), repositioned from BOR, placement is questionable, see unit 144

144. Very carbonaceous shale, brownish-black 5YR 2/1, with black coaly plant debris, fairly brittle, almost a coaly shale, massive except for coaly debris, scattered matrix-supported sand grains, base grades (nb: this unit may actually be part of the dirty coal ascribed to unit 143), sample PA-2-M 255.1-255.3 (pollen) .$(255.7)$

145. Carbonaceous shale, dusky-yellow-brown 10YR 2/2, less coaly than unit 144, has an ashy texture (volcanic detritus?) and abundant very pale orange 10YR 8/2, irregular kaolin streaks, sample USGS-PA-2-2R 0.7

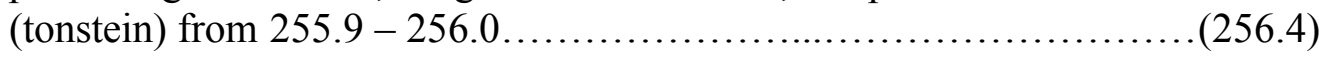

146. Coal, black, dull, nonbanded, conchoidal fracture, pyritic lamella $\quad 0.03$ on bedding. 
147. Carbonaceous shale similar to unit 145 except has very fine to fine-

148. Coal, black, dull, nonbanded, conchoidal fracture, sandy horizontal

150. Core loss, probably coarsening-up sandstone (elog)

151. Sandy coal, very dirty, out of place?, driller placed here, elog shows 0.3 shaley zone in sand.

152. Core loss, probably coarsening-up sandstone (elog), BOR

153. Sandstone, light-olive-gray, very fine grained, subangular, well-sorted, sugary, faintly flat-bedded to massive, some horizontal burrows, carbonaceous laminae in places, more in bottom half, BOR

154. Sandstone, light-olive-gray 5 Y $6 / 1$, muddy, abundant small-scale lowangle cross-sets (ripples?) that show internal scouring, cross-sets are comprised of carbonaceous laminae $<1 \mathrm{~mm}$ thick and sand laminae from one to several $\mathrm{mm}$ thick, cross-sets are in regular $10 \mathrm{~mm}$ couplets that may be tidal in origin, also some flat parallel planar laminations, sharp contact with unit 155

155. Coal, brownish-black to black, nonbanded, brittle, sharp contact with 0.05 unit 156.

156. Sandstone, similar to unit 154 , but bedding is very disturbed, looks $\quad 1.55$ compaction or small-scale fault related, BOR

157. Carbonaceous siltstone, dark-yellowish-brown 10YR 4/2 (chocolate), pyritized plant fragments on bedding, top is more carbonaceous, base grades

158. Siltstone, light-brownish-gray 5 YR 6/1, lighter color and less carbonaceous than unit 157 , base grades

159. Sandstone, light-olive-gray to light-brownish-gray, very fine-grained, muddy, faint flat-bedded laminations, some green minerals - possibly glauconite (see unit 168). 
160. Core loss, probably sandy mudstone similar to unit 161 , repositioned 1.4

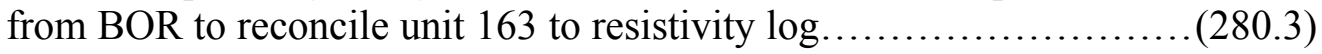

161. Mudstone, light-olive-gray to olive-gray, sandy silt matrix with 0.7 abundant sand-filled burrows, sharp contact with unit $162 \ldots \ldots \ldots \ldots \ldots(281.0)$

162. Sandstone?, very hard, no effervescence with HCL, matrix is very sparry and carbonate may dominate over quartz, large brick-red broad-leaf impression

164. Sandstone, very fine grained, light-olive-gray to light-gray, salt and pepper

165. Core loss, probably sandstone like unit 164, BOR (switched to $5 \mathrm{ft}$ solid tube).....

166. Sandstone, light-olive-gray, very fine to fine-grained, salt and pepper, $\quad 4.0$ a few pct dark minerals, micaceous, very faintly bedded.

167. Core loss, probably sandstone like unit 166 , BOR $(290.0)$

168. Sandstone, similar to unit 166 , has light and dark green minerals which appear to be epidote based on color and luster, but may be glauconite, very friable

0.4

169. Core loss, sandstone as above (elog), BOR

170. Sandstone, similar to unit $168,1-2$ pct dark minerals, BOR, (switched to split tube)

171. Sandstone, light-olive-gray, very fine-grained?, hard, matrix effervesces with HCL if powdered, siderite? (dolomite?), sub-mm-scale flat-bedded laminations (artifacts of spun core?), abundant coalified plant debris $\quad 1.6$ along bedding, abundant tannish-brown lithic? fragments throughout...(298.0)

172. Carbonaceous siltstone, dusky-yellowish-brown 10YR 2/2, with sandfilled vertical burrows, grades downward to less-carbonaceous olive-gray 0.5 $5 \mathrm{Y} 4 / 1$ mudstone with light-olive-gray 5Y 6/1 muddy sand layers. (298.5) 
173. Core loss, probably sandy mudstone like the base of unit 172 (elog)....(300.5)

174. Core loss, probably muddy sandstone like unit 175 (elog)

175. Sandstone, light-olive-gray, very fine to fine-grained, muddy, massive, base grades.

176. Siltstone, brownish-gray 5YR 4/1, muddy, micaceous, vertical sand- $\quad 0.5$ filled burrows $(302.8)$

177. Hard sandstone, similar to unit 171 but somewhat siltier and does not 0.2 effervesce, abundant carbonaceous laminae at base...

178. Core loss, probably sandstone similar to unit 175 (elog - repositioned 2.0 from units 173-174 to match 177 with density log), BOR

179. Sandstone, olive-gray 5Y 4/1, very fine grained, very muddy, almost $\quad 0.4$ a mudstone, massive... .(305.4)

0.6

180. Core loss, probably sandstone like unit 179 (306.0)

0.2

181. Siltstone, olive-black 5 Y 2/1, slightly carbonaceous, base grades .(306.2)

0.3

182. Siltstone, similar to unit 181 , sandy (306.5)

0.5

183. Siltstone, same as unit 181 , base grades (307.0)

184. Mudstone, olive-black, subequal amounts of sand silt and clay (307.5)

1.0

185. Siltstone, similar to unit 181 , contains resin? specks, base grades (308.5)

186. Siltstone, olive-gray, grading down to olive-black, with very fine1.3 grained flat-bedded sand laminae $<1 \mathrm{~mm}$ thick in the bottom part......(309.8)

187. Core loss, probably siltstone similar to unit 181 (elog) .(312.0) 
188. Core loss, probably sandy siltstone similar to bottom part of unit

186 (elog).

189. Siltstone, similar to bottom part unit 186 , but bedding is disturbed,

0.6

BOR (this was excess recovered in next run)....

190. Siltstone, olive-black, muddy, with sub-mm-scale sandstone laminae and thicker lenses, bedding is flat to slightly inclined and possibly internally scoured (ripples?), possible horizontal burrows, siderite? band at 318.3 4.0 $\mathrm{ft}, \mathrm{BOR}$ (continuing short runs with split tube to minimize core loss)... (319.0)

191. Siltstone, olive-black, clayey, sand laminations $<1 \mathrm{~mm}$ thick throughout, flat-bedded, base is less sandy with siltstone bands getting thicker 3.9 (5-10 mm) towards base, sample PA-2-N 319.2-319.3 (pollen).

192. Core loss, siltstone, BOR

193. Siltstone, olive-gray, mostly massive, with some sub-mm-scale sand laminae and lenses

194. Siltstone, same as above but bedding is disturbed, recovered by 1.0 redrilling with $5 \mathrm{ft}$ solid tube, placement is estimated from elog....

195. Core loss, siltstone slightly more sandy than unit 194 (elog), possibly sideritic in places (density), BOR, switched to $5 \mathrm{ft}$ solid tube.

196. Siltstone, olive-gray 5 Y $4 / 1$ to brownish-gray 5 YR 4/1, very regular sub-mm to mm-scale sand laminations throughout, sets of thin laminae are coupled with thicker sand bands at very regular $25 \mathrm{~mm}$ intervals (tidal rhythmites?), $10 \mathrm{~mm}$ carbonaceous band at $334 \mathrm{ft}$, sample $\mathrm{PA}-2-3 \mathrm{R}$ for isotopes, BOR.

197. Siltstone, olive-black 5Y 2/1, regular sandstone laminations throughout, sandstone is very fine grained, sugary, and micaceous, bedding is similar to unit 196 except at base cycles are compressed, sandier, and slightly inclined, carbonaceous layer at 338.6, pollen sample PA-2-O 338.6-338.7

198. Siltstone same as unit 197 (excess recovered from prior run)

199. Core loss, siltstone similar to above (elog) (340.2) 
200. Siltstone similar to above, olive-gray to olive-black, bedding is flat

201. Siltstone, olive-black, sideritic

202. Core loss, probably siltstone slightly more sandy than above, BOR (switched to $10 \mathrm{ft}$ tube but doing $5 \mathrm{ft}$ runs)

203. Siltstone, similar to above, olive-black, sand laminae are flat-bedded to slightly inclined, becoming closer spaced and ripple bedded at 348.1, at 345.7 and $346.1 \mathrm{ft}$ there are ash or sideritic bands $10 \mathrm{~mm}$ and $5 \mathrm{~mm}$ thick respectively (this unit was repositioned from 346.3-350), sample

204. Core loss, sandy siltstone (elog), BOR

205. Siltstone, similar to unit 203 , but sand laminae are generally closer together and base is less sandy. This unit was recovered in run from 350-355, but has been repositioned from 350.4-354.7 to reconcile top of coal to elog. Apparently core dropped from several $5 \mathrm{ft}$ runs drilled with $10 \mathrm{ft}$ tube in place

206. Mudstone, dusky-yellowish-brown 10YR 2/2, similar to laminated siltstones above, but sand is more disseminated in a silty matrix. Some lenses of very fine-grained sand, some horizontal burrows, possibly some flasers and current rippling at the top and middle. Unit was recovered in run from 355-360 (total recovery in run $5.3 \mathrm{ft}$ )

207. Coal, immediately placed in desorption canisters and not described at drill site. Sample numbers below refer to desorption canisters and any subsequent analysis (e.g. prox/ultimate). Depth adjustments were made to reconcile with elogs under the assumption that core was dropped from $5 \mathrm{ft}$ runs made with the $10 \mathrm{ft}$ split tube. Desorption was completed in the field, and some samples (CN8-17) were briefly described as noted below before rebagging for shipment. More detailed descriptions occur elsewhere in this volume (Chapter 3). CN1T is a (reworked?) tonstein estimated 80 pct clay/20 pct organic. It was included in the canister 1 desorption, but reserved for radiometric dating and not submitted for proximate/ultimate or trace element analyses with the other samples. BOR's at 360.0, 365.0, 370.0 , and $375.0 \mathrm{ft}$.

USGS-PA-2-CN1T, 355.0-355.15 (adjusted from 356.6-356.75)

USGS-PA-2-CN1, 355.15-356.0 (adjusted from 356.6-357.6) 
USGS-PA-2-CN2, 356.0-357.0 (adjusted from 357.6-358.6)

USGS-PA-2-CN3, 357.0-358.0 (adjusted from 358.6-359.6)

USGS-PA-2-CN4, 358.0-358.4 (adjusted from 359.6-360.0)

USGS-PA-2-CN5, 358.4-359.4 (adjusted from 360.0-361.0)

USGS-PA-2-CN6, 359.4-360.5 (adjusted from 361.0-362.1)

USGS-PA-2-CN7, 360.5-361.4 (adjusted from 362.1-363.0)

USGS-PA-2-CN8C, 361.4-361.95 (adjusted from 363.0-364.0), coal

is very dull attritus (earthy) with plant fragments along bedding.

USGS-PA-CN8P parting from 361.95-362.44

USGS-PA-2-CN9C, 362.44-363.27 (adjusted from 364.0-365.0), dull attritus, olive black 5Y 2/1, earth-looking, plant impressions along bedding, poor cleat, not brittle, appears somewhat dirty.

USGS-PA-2-CN9P, 363.27-363.40 parting

CORE LOSS in coal, 363.4-365.0 (bit plugged at 365.0, pulled split tube and dropped $5 \mathrm{ft}$ push tube with wireline to clear bit.

PA-2-Q, 365.0-365.1, coal, not desorbed, back-up pollen sample taken from push tube shoe after clearing bit. Depth adjustments reconciled to this point. CORE LOSS in coal, 365.1-365.4 (nb: cannister 10 not used, seal broken) USGS-PA-2-CN11, 365.4-366.5, core badly broken, dull but less earthy than above, brownish-black 5YR 2/1 to black, some previtrain bands, a little blockier than above, but still fractures irregularly on bedding.

USGS-PA-2-CN12, 366.5-367.5, core badly broken, similar to CN11, brownish-black.

USGS-PA-2-CN13, 367.5-368.8, core badly broken, very dull and earthy looking with a brownish cast, a few previtrain bands (possible parting on elog) USGS-PA-2-CN14, 368.8-370.0, core badly broken, somewhat more banded than $\mathrm{CN} 13$ but still very earthy.

USGS-PA-2-CN15, 370.0-371.0, new run, core intact, more banded than

$\mathrm{CN} 14$, but still earthy appearance on bedding planes and face.

USGS-PA-2-CN16, 371.0-372.0, similar to CN15

USGS-PA-2-CN17, 372.0-373.0, possibly slightly more banded going down PA-2-R, back-up pollen sample, core chips from approximately $373 \mathrm{ft}$.

CORE LOSS in coal, 373.0-373.2

Total coal unit 207

208. Core loss, probably coaly shale or dirty coal (elog), possibly a thin bed 1.8 of sandstone, BOR (swiched to $5 \mathrm{ft}$ solid tube)

209. Core loss, presumably coaly shale (recovered loose sand, probably from 0.3 above, but possibly in place).

210. Coaly shale, olive black, slickensides, coaly layers, est $50-60 \mathrm{pct}$ ash, $\quad 0.5$ bottom 0.1 recovered next run, sample PA-2-S 375.6-375.7 (pollen)....(375.8) 
211. Siltstone, olive-black 5Y 2/1 to greenish-black 5GY 2/1 (chocolate), clayey, coal spars, horizontal sand filled burrows, massive, BOR (bit plugged, this unit excess recovered from next run, $10 \mathrm{ft}$ split tube)......(376.2)

212. Siltstone, same as unit 211, some sandy and resinous laminae at 2.8 bottom, sample PA-2-T 378.6-378.7 (pollen).

213. Sandstone, olive-gray, $5 \mathrm{Y} 4 / 1$, very muddy, top is very fine-grained, micaceous, faintly laminated, with some disturbed bedding, probably bioturbated, base is fine- to very fine-grained, poorly sorted, $4-5 \mathrm{pct}$ dark minerals, contains sand-sized lithic fragments, organic debris, throughout, faint cross-laminations and possible ripples, BOR

214. Core loss, probably sandstone similar to unit 214 (elog)

215. Sandstone, similar to unit 213 , very fine to fine-grained, poorly sorted, micaceous, 3-4 pct dark minerals, very faint $\mathrm{mm}$-scale laminations which increase towards base, flat- to ripple-bedded, fairly indurated except soft 3.6 from 390.8-391.4, base grades, isotope sample PA-2-4R 393.2-393.33 (394.0)

216. Interlaminated olive-black siltstone and light-olive-gray sandstone, sandstone is very fine-grained, sugary, micaceous, laminations are $\sim 1$ $\mathrm{mm}$ thick throughout, very regular, looks tidal, sample PA-2-U 394.5- 1.0 394.6 (pollen/dinocysts), sample PA-2-5R 395.6-395.7 (isotopes), BOR.(395.0)

217. Interlaminated olive-black 5 Y $2 / 1$ siltstone and light-olive-gray 5 Y $6 / 1$ dirty sandstone similar to unit 216 , mostly flat-bedded with a few pseudo-flasers, tope of core is badly broken.

218. Core loss (400.0)

TOTAL DEPTH 400 FT 


\section{Chapter 3}

\section{Laboratory coal core and tonstein descriptions/photos from boreholes USGS-PA-1 and USGS-PA-2}

By Ronald W. Stanton' and John R. SanFilipo'

Chapter 3 of

Results of coalbed methane drilling in Panola County, Texas

Edited By Peter D. Warwick', John R. SanFilipo', Alex W. Karlsen', and Charles E. Barker ${ }^{2}$

'U.S. Geological Survey, Reston, VA

2U.S. Geological Survey, Denver, CO

Open-File Report 2005-1046

U.S. Department of the Interior

U.S. Geological Survey 
----NOT TO SCALE-------

Final thickness and reconciliation to core/elog depths (ft).

Sample 1.1A not desorbed Sample 1.1B not desorbed

Sample 1.2 trace of gas

130.7

130.7

Sample 1.3 not desorbed

132.8

331.0

Sample 1.4

331.25-331.50 removed as sample $1.4 \mathrm{~T}$

334.0

334.0

Sample 1.5

337.0

337.0

Sample 1.6

340.0

340.0

Sample 1.7

Sample 1.8

343.0

346.0

346.0

Sample 1.9

\section{Texas Core USGS-PA-1}

\section{Laboratory redescriptions by Stanton/SanFilipo}

1.5 " Light grey-yellow clay (not included in sample)

1.5-8.5" dark clay, organic rich, laminae bedded, clayey streak

8.5-18.5" Attrital coal; few vitrain laminae $<1 \mathrm{~mm}$

minor chip fusain on breaks

Mix of attrital coal and finely laminated

broken pieces; 12 pieces

one piece dense; one has vitrain spars; one has laminations

vitrain $1 \mathrm{~mm} /$ attritus $5 \mathrm{~mm}$; two vitrain $3 \mathrm{~mm} /$ attritus $1-2 \mathrm{~mm}$

Attrital coal and very finely laminated

Half of blocks are attrital coal

with sand burrows and fusain on all breaks

Remaining blocks are very finely laminated

(vitrain 2-3 mm/attritus $8-10 \mathrm{~mm}$ )

$2 / 5$ of blocks are attrital rich with clay blebs

$3 / 5$ of blocks are fusain rich, laminated vitrain $<1 \mathrm{~mm} /$ attritus $1 \mathrm{~mm}$;

near top is reworked(?) tonstein: 1.8 " yellow brown kaolinitic

clay flasers with $20 \%$ coaly stringers at top; 1.2 " coal with clay filled burrows at base - SAMPLE 1.4T (age-dating)

$1 / 3$ fusain-rich laminated; about $2 "$ canneloid;

4" clay-rich attrital; $1 / 3$ attrital rich with fusain, some clay burrows; $1 / 3$ finely laminated with little fusain; 4 " woody

Attrital/fusain laminated coal

2" woody chunk

Finely laminated, fusain-rich coal

Attrital-rich coal blocks

with fusain chips; mostly attritus;

no appreciable vitrain spars; one block has

about 50/50 fusain-rich and attrital blocks

Attrital coal

Few vitrain spars about $1 \mathrm{~mm}$

4 pieces about $3.5^{\prime \prime}$ of lam clay-rich/coal

very fissile
Except as noted, all samples desorbed with no gas observed.

347.7

(refer to core descriptions for sampling details)

\section{$\underline{\text { Key to facies descriptions }}$}

unlaminated attrital coal

finely laminated attrital coal

finely laminated vitrain/attrital coal moderately laminated vitrain/attrital coal

parting

fusain rich

dirty coal be correct. Borehole depths shown at top and base of sample intervals only. 


\section{Texas Core USGS-PA-2}

Final thickness and reconciliation to core/elog depths (ft).

356.0

355.0

355.15

356.0

CN2

357.0

357.0

CN3

CN4

358.4

358.4

CN5

359.4

358.0

358.0

359.4

CN6

360.5

360.5

CN7

361.4

361.4

CN8

CN9

CN10 seal broken - not used

CN11

366.5

366.5

CN12

362.4

\section{Laboratory redescriptions by Stanton/SanFilipo}

$\mathrm{CN}$ refers to desorption cannister number and except as noted analytical samples

(refer to core descriptions for sampling details)

1.8 "reworked(?) tonstein - yellowish brown kaolinitic clay flasers with approx $30 \%$

coal stringers top $0.7 ", 10 \%$ coal stringers base $1.1 "$ - sample CN1T (age-dating)

10.2" finely laminated atttritus - fusain streak

laminae $<1 \mathrm{~mm}$ thickness - sample CN1 (PHOTO LINK)

finely laminated attritus

$\begin{aligned} & \text { one piece conatins vitrain about } 2 \mathrm{~mm} \text { thick } \\ & \text { laminae }<1 \mathrm{~mm}\end{aligned} \quad \begin{aligned} & \mathrm{CH}_{4} \text { isotherm } \\ & \text { sample }\end{aligned} \quad \mathrm{CO}_{2}$ isotherm sample

rich in fusain chips (PHOTO LINK)

finely laminated

2 pieces contain woody chip about $1 \mathrm{~cm}$ thick

most laminae $<1 \mathrm{~mm}$

rich in fusain (some chips contain white mineral filling)

attrital coal

few laminae

fusain-rich fine sand on cleat - drilling mud??

finely laminated with abundant chip fusain (PHOTO LINK)

few small frag. of woody about $1 \mathrm{~cm}$ thick

few vitrain. laminae $(1 \mathrm{~mm})$

half of blocks well cleated with 1 major cleat

about $40 \%$ of section is finely laminated

vitrain $2-3 \mathrm{~mm} /$ attritus $10-12 \mathrm{~mm}$

$60 \%$ is moderately laminated

vitrain $10 \mathrm{~mm} /$ attritus $8-10 \mathrm{~mm}$
$\mathrm{CH}_{4}$ isotherm

sample broken into 6 pieces

moderately laminated/some fusain along 6 broken surfaces

vitrain $8-10 \mathrm{~mm} /$ attritus $8-10 \mathrm{~mm}$ (some part consist of finely laminated interval with

vitrain $1 \mathrm{~mm} /$ attritus $2 \mathrm{~mm}$

5.5" coal - very woody and coarsely laminated (no attritus/no fusain) SAMPLE CN8C

$1.1 "$ coal - moderately laminated INCL SAMPLE CN8C w/ 5.5" above (PHOTO LINK)

5" parting - medium gray clay/shale - SAMPLE CN8P

0.5 " parting (put into SAMPLE 8P)

8 " finely laminated vitrain 1-2 mm/attritus $1-2 \mathrm{~mm}$ grading to bottom where attritus dominates CN9C

2" attritus dominant - INCL SAMPLE CN9C with 8" above (PHOTO LINK)

$1.5 "$ shale dark gray very fissile (paper) SAMPLE CN9P

$0.1^{\prime}$ coal recovered $363.4-365.4$

broken pieces

one piece has very woody laminae

moderately to coarsely woody frags - few layers of fusain

broken pieces (11 pieces 1-2" thick)

most all are attritus rich with very little fusain

dense piece is dark brown to black (clay rich)

one piece has wood frag about $1 \mathrm{~cm}$ thick

all other peices are attritus rich, vitrain $<1 \mathrm{~mm}$

$\mathrm{CH}_{4}$ isotherm

sample 
CN13

broken pieces - dominantly attrital rich

very little fusain one piece with vitrain band about $5 \mathrm{~mm}$ thick/ all others vitrain $<1 \mathrm{~mm}$ attritus $>20 \mathrm{~mm}$

368.8

CN14

9" finely laminated vitrain-1 mm/attritus 4-6 mm, well cleated

370.0

5 " woody - concoidal fracture, hard and uneven breakage

370.0

CN15

\section{$0-3.5^{\prime \prime}$ attritus/fusain rich; no vitrain}

3.5-7" moderate laminae; vitrain $4 \mathrm{~mm} /$ attritus $2 \mathrm{~mm}$

$7-12$ " moderate laminae; vitrain $5 \mathrm{~mm}$ /attritus $2 \mathrm{~mm}$

$371.0 \_$12-12.5" attritus

$371.0 \quad 0-2$ " fine fusain laminae; vitrain-1 $\mathrm{mm} /$ fusain $1 \mathrm{~mm}$

2-6" moderate. laminae vitrain-10/fusain $2 \mathrm{~mm}$

$6-8$ " hard/ fusain rich layers $\mathrm{w} /$ vitrain- $1 \mathrm{~mm}$

$\mathrm{CH} 4$ isotherm

$8-12$ " hard fine laminae vitrain $1-2 \mathrm{~mm} /$ fusain $10-12 \mathrm{~mm}$

sample

(PHOTO \& X-RAY

cleat at base 1-2 $\mathrm{cm}$ spacing

372.0

finely laminated - broken pieces

vitrain $2-5 \mathrm{~mm} /$ attritus $10-15 \mathrm{~mm}$

some resin on horizontal break plane in cleats and blebs

(PHOTO LINK)

373.0

\section{Key to facies descriptions}

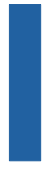

unlaminated attrital coal

(PHOTO LINK-CN14)

finely laminated attrital coal

(PHOTO LINK-CN12)

finely laminated vitrain/attrital coal

(PHOTO LINK-CN1) fusain rich

(PHOTO LINK-CN2 \& CN5)

woody

(PHOTO LINK-CN13)

parting

(PHOTO LINK-CN9)

moderately laminated vitrain/attrital coal

(PHOTO LINK-CN8)

$\mathrm{nb}$ : orientation of facies within cannisters was reconstructed to the degree possible but may not be correct. Bore depths shown at top and base of cannister and sampled intervals only. 


\section{Detailed descriptions of suspected reworked tonsteins, boreholes, USGS-PA-1 and USGS-PA-2}

Samples described by John SanFilipo at USGS Reston on Aug 25, 1999

USGS-PA-1 $\quad 331.25$-331.50 ft. (see unit 179 of field core descriptions)

Top $0.15 \mathrm{ft}$ is approximately $80 \%$ dusky yellowish brown $10 \mathrm{YR} 4 / 2$ reworked flaser-like apparently kaolinitic clay and approximately $20 \%$ thin coal stringers; slightly more coal at very top, grading to overlying coal; base is fairly sharp, but vertical and inclined clay filled burrows (?) in bottom $0.10 \mathrm{ft}$. Sample USGS-PA-1-1.4T (age dating only)

\section{USGS-PA-2 $\quad 355.0-335.15 \mathrm{ft} \quad$ (see unit 207 of field descriptions)}

Top $0.06 \mathrm{ft}$ is approximately $30 \%$ coal stringers with $70 \%$ reworked moderate yellowish brown 10YR 5/4 flaser-like homogenous apparently kaolinitic clay; basal $0.09 \mathrm{ft}$ is similar, but approximately $90 \%$ reworked clay. No loss recorded in run, but top is spun and there could be lost coal above; base grades into underlying coal. Sample USGS-PA2 -CN1T (age dating only) re-estimated at $82 \%$ ash and 5\% moisture to calculate DAF gas for Cannister 1.

Note: These detrital clay beds occupy the same interval in the top of the Naborton 2 coal bed with remarkable persistence throughout the Sabine uplift area of Louisiana and Texas, and are therefore thought to be quite likely reworked ash-falls (tonsteins; see Ruppert and Warwick, 1994). To date these have not provided dateable material using conventional HF acid digest (see below):

Additional notes from Geochronology lab analysis:

Sanidine and microcline were detected in samples USGS-PA-2-CN1T and OB94-WO1$\mathrm{C}(54.8-55)$. Sanidine crystals were determined to be to small for age dating.

\section{Literature Cited}

Ruppert, L.F., and Warwick, P.D., 1994, Volcanic ash fall material in the Chemard Lake lignite, Naborton Formation, Desoto and Red River Parishes, Louisiana: The Society for Organic Petrology, Eleventh Annual Meeting Abstracts and Program, Jackson, Wyoming, v.11, p. 90. 


\section{Chapter 4}

\section{Geophysical logs from boreholes USGS-PA-1 and USGS-PA-2}

By Alex W. Karlsen ${ }^{1}$ and Peter D. Warwick ${ }^{1}$

Chapter 4 of

Results of coalbed methane drilling in Panola County, Texas

Edited By Peter D. Warwick', John R. SanFilipo', Alex W. Karlsen', and Charles E. Barker²

'U.S. Geological Survey, Reston, VA

${ }^{2}$ U.S. Geological Survey, Denver, CO

Open-File Report 2005-1046

U.S. Department of the Interior

U.S. Geological Survey 


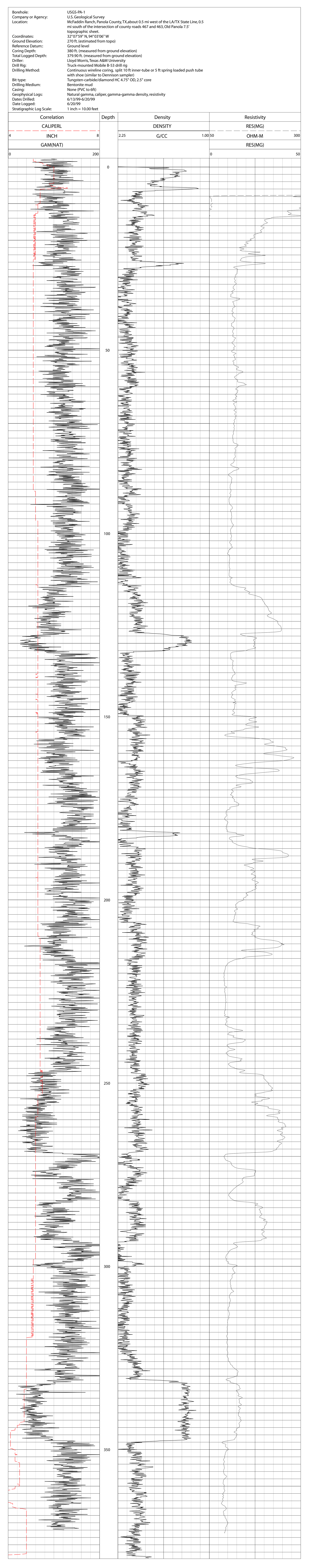




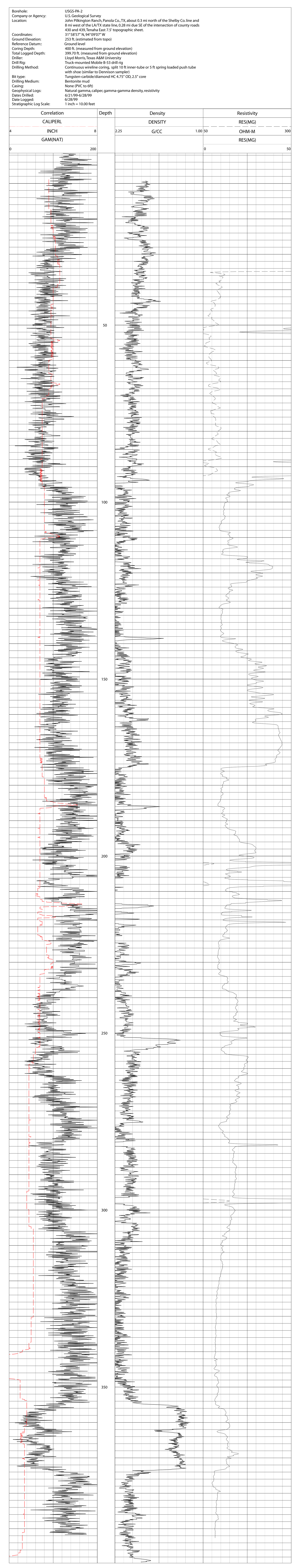




\section{Chapter 5}

\section{Petrographic data from borehole USGS-PA-2}

By Ronald W. Stanton ${ }^{1}$

Chapter 5 of

Results of coalbed methane drilling in Panola County, Texas

Edited By Peter D. Warwick', John R. SanFilipo', Alex W. Karlsen', and Charles E. Barker ${ }^{2}$

'U.S. Geological Survey, Reston, VA

'U.S. Geological Survey, Denver, CO

Open-File Report 2005-1046

U.S. Department of the Interior

U.S. Geological Survey 
Table 1. Preliminary petrographic data for coal samples from borehole USGS-PA-2. Percentages are based on a total of 500 (or fewer) point counts on duplicate particle pellets with white reflected light. No blue light (fluorescence) point counts are included. All values are volume

percent on a mineral-matter-free basis. Refer to Chapter 2, this volume, for sample intervals. $\mathrm{Tr}=\operatorname{trace}$, or less than 1 percent.

\begin{tabular}{|c|c|c|c|c|c|c|c|c|c|c|c|c|c|c|c|}
\hline $\begin{array}{l}\text { Sample } \\
\text { number }\end{array}$ & Telinite & $\begin{array}{l}\text { Desmo- } \\
\text { collinte }\end{array}$ & $\begin{array}{l}\text { Vitro- } \\
\text { detrinite }\end{array}$ & $\begin{array}{l}\text { Corpocollinite } \\
\text { in telinite }\end{array}$ & $\begin{array}{l}\text { Corpocollinite } \\
\text { in detrinite }\end{array}$ & $\begin{array}{c}\text { Total } \\
\text { vitrinite }\end{array}$ & Sporinite & Resinite & Cutinite & $\begin{array}{l}\text { Lipto- } \\
\text { detrinite }\end{array}$ & $\begin{array}{c}\text { Total } \\
\text { liptinite }\end{array}$ & Fusinite & $\begin{array}{l}\text { Semi- } \\
\text { fusinite }\end{array}$ & $\begin{array}{l}\text { Inerto- } \\
\text { detrinite }\end{array}$ & $\begin{array}{c}\text { Total } \\
\text { inertinite }\end{array}$ \\
\hline PA2-CN12 & 24 & 27 & 14 & 2 & 4 & 72 & 2 & 6 & 2 & 1 & 11 & 4 & 6 & 7 & 17 \\
\hline PA2-CN2 & 15 & 30 & 6 & 2 & 1 & 54 & 7 & 2 & 0 & 0 & 9 & 2 & 9 & 26 & 36 \\
\hline PA2-CN6 & 6 & 37 & 14 & 7 & 2 & 67 & 9 & 0 & 3 & 0 & 12 & 4 & 9 & 8 & 21 \\
\hline PA2-CN16 & 22 & 35 & 9 & 6 & 2 & 74 & 8 & 1 & 1 & $\operatorname{Tr}$ & 10 & 4 & 8 & 5 & 16 \\
\hline
\end{tabular}

Table 2. Mean vitrinite reflectance (\%Ro) based on less than 25 spot measurements per sample.

\begin{tabular}{lr}
$\begin{array}{l}\text { Sample } \\
\text { number }\end{array}$ & \multicolumn{2}{c}{ \%Ro } \\
PA2-CN12 & 0.38 \\
PA2-CN2 & 0.45 \\
PA2-CN6 & 0.43 \\
PA2-CN16 & 0.37
\end{tabular}




\section{Chapter 6}

\section{Pollen data from boreholes USGS-PA-1 and USGS-PA-2}

By Douglas J. Nichols

Chapter 6 of

Results of coalbed methane drilling in Panola County, Texas

Edited By Peter D. Warwick', John R. SanFilipo', Alex W. Karlsen', and Charles E. Barker²

'U.S. Geological Survey, Reston, VA

${ }^{2}$ U.S. Geological Survey, Denver, CO

Open-File Report 2005-1046

U.S. Department of the Interior

U.S. Geological Survey 


\section{POLLEN SAMPLES FROM CORE USGS PA-1}

This is the final report on palynological analyses of samples from USGS Core PA-1, Panola County, Texas. This report covers 11 rock samples collected from the part of the core stored at Texas A\&M University (TAMU) (see Tables 1 and 3) which lists interpretations of age and depositional environments. A list of palynomorphs is included in Table 2. Such species lists contribute toward compilation of a palynostratigraphic database for the Gulf Coast Tertiary. Photomicrographs of selected specimens are available.

The age of most samples analyzed from this core is late Paleocene, both on the basis of fossil pollen species known to have restricted stratigraphic ranges in the Gulf Coast region and on the basis of the presence of a species known to be a key palynostratigraphic guide fossil in the Rocky Mountain region. One sample from near the bottom of the hole yielded a species that in the Rockies is indicative of middle Paleocene age (its range in the Gulf Coast is uncertain), but the sample below that one appears still to be late Paleocene. Thus, the interesting possibility that we had pinpointed the age of the cored interval more narrowly than late Paleocene apparently was not substantiated. In future analyses such possibilities will be continue to be pursued.

All but one of these samples yielded marine dinoflagellate cysts (dinocysts). Their presence is indicative of marine influence in the depositional environment, although the assemblages from all samples are overwhelmingly of nonmarine origin, and freshwater algal cysts are present in some samples. An estuarine depositional environment could have such a mix of palynomorphs.

Table 1. Age and depositional environments of selected samples from core USGS-PA-1.

Sample Depth Lithology Results

D9154-A $\quad 19.8-19.9 \mathrm{ft} \quad$ laminated claystone Sample yielded a very diverse palynomorph assemblage indicative of late Paleocene age. Assemblage is composed predominantly of terrestrial pollen, but includes freshwater algae. It also includes dinoflagellate cysts of marine origin. Thus, marine influence in the depositional environment is indicated.

D9154-D 38.0-38.1 mudstone with flaser bedding
Pollen and spore assemblage indicative of late Paleocene age. Cysts of freshwater algae are relatively abundant. Marine dinocysts are present also, indicating marine 
influence in the depositional environment.

\begin{tabular}{|c|c|c|c|}
\hline D9154-F & $83.5-83.6$ & $\begin{array}{l}\text { "chocolate" } \\
\text { siltstone }\end{array}$ & $\begin{array}{l}\text { Pollen indicative of late Paleocene age. } \\
\text { Some freshwater algae present. Marine } \\
\text { dinocysts rare but present. }\end{array}$ \\
\hline D9154-H & $97.7-97.8$ & $\begin{array}{l}\text { argillaceous } \\
\text { sandstone }\end{array}$ & $\begin{array}{l}\text { Pollen indicative of late Paleocene age } \\
\text { present. Sample was collected at request of } \\
\text { TAMU staff because it was suspected that it } \\
\text { might contain marine dinocysts. Dinocysts } \\
\text { indicating marine influence are present. }\end{array}$ \\
\hline D9154-K & $138.0-138.1$ & $\begin{array}{l}\text { "chocolate" } \\
\text { claystone }\end{array}$ & $\begin{array}{l}\text { Pollen indicative of late Paleocene age. } \\
\text { Marine dinocysts rare but present. }\end{array}$ \\
\hline D9154-M & $179.9-180.0$ & $\begin{array}{l}\text { olive laminated } \\
\text { claystone }\end{array}$ & $\begin{array}{l}\text { Pollen indicative of late Paleocene age. } \\
\text { Marine dinocysts relatively abundant. This } \\
\text { sample shows the most marine influence in } \\
\text { the depositional environment of any } \\
\text { collected from this core. }\end{array}$ \\
\hline D9154-P & $184.7-184.8$ & $\begin{array}{l}\text { "chocolate" } \\
\text { claystone }\end{array}$ & $\begin{array}{l}\text { Pollen indicative of late Paleocene age. } \\
\text { Marine dinocysts present. }\end{array}$ \\
\hline D9154-R & $209.5-209.6$ & $\begin{array}{l}\text { "chocolate" } \\
\text { claystone }\end{array}$ & $\begin{array}{l}\text { Pollen indicative of late Paleocene age. } \\
\text { Marine dinocysts present. }\end{array}$ \\
\hline D9154-T & 239.8-239.9 & $\begin{array}{l}\text { carbonaceous } \\
\text { claystone }\end{array}$ & $\begin{array}{l}\text { Pollen indicative of late Paleocene age. } \\
\text { Marine dinocysts present. }\end{array}$ \\
\hline D9154-V & $318.0-318.1$ & $\begin{array}{l}\text { laminated } \\
\text { claystone }\end{array}$ & $\begin{array}{l}\text { Assemblage indicative of Paleocene age, but } \\
\text { no species definitive of late Paleocene age } \\
\text { was observed, and one species indicative of } \\
\text { middle Paleocene age in the Rocky } \\
\text { Mountain region is present. Marine } \\
\text { dinocysts present. }\end{array}$ \\
\hline D9154-W & $330.5-330.6$ & $\begin{array}{l}\text { carbonaceous } \\
\text { mudstone or } \\
\text { dirty coal }\end{array}$ & $\begin{array}{l}\text { Some pollen indicative of late Paleocene age } \\
\text { is present in the assemblage. No marine } \\
\text { dinocysts observed. }\end{array}$ \\
\hline
\end{tabular}


Table 2. List of palynomorphs for selected samples from core USGS-PA-1.

\section{Sample}

D9154-A

D9154-D

\section{Palynomorphs}

Arecipites sp.

Caryapollenites inelegans

Caryapollenites veripites

Caryapollenites wodehousei

Cicatricosisporites sp.

Corollina sp.

Erdtmanipollis sp.

Extratriporopollenites sp.

Laevigatosporites sp.

Momipites coryloides

Momipites ventifluminis

Myocolpopollenites reticulatus

Nyssapollenites sp.

Osmundacidites $\mathrm{sp}$.

Pityosporites sp.

Quadrapollenites vagus

Retitriletes sp. ("Lycopodiumsporites")

Rhoipites sp.

Sernapollenites duratus

Stereisporites spp.

Taxodiaceaepollenites hiatus

Thomsonipollis magnificus

Tricolpites spp.

"Tricolpopollenites baculoferus"

Triporopollenites spp.

Pediastrum sp.

Tetraporina $\mathrm{sp}$.

unidentified trilete spores

unidentified acritarch

unidentified dinocysts

Alnus speciipites

Arecipites sp.

Caryapollenites prodromus

Caryapollenites veripites

Caryapollenites wodehousei

Cicatricosisporites sp.

Corollina sp.

Hamulatisporis amplus

Laevigatosporites sp.

Momipites coryloides

Momipites tenuipolus 
Momipites ventifluminis

Nyssapollenites sp.

Pityosporites sp.

Reticuloidosporites pseudomurii

Rhoipites sp.

Stereisporites spp.

Taxodiaceaepollenites hiatus

Thomsonipollis magnificus

Tilia vescipites

Tricolpites spp.

Ulmipollenites sp.

Pediastrum sp. [relatively abundant]

unidentified dinocyst

D9154-F

Arecipites sp.

Caryapollenites veripites

Cicatricosisporites sp.

Deltoidospora sp.

Holkopollenites chemardensis

Laevigatosporites sp.

Momipites ventifluminis

Reticuloidosporites pseudomurii

Rhoipites sp.

Stereisporites spp.

Taxodiaceaepollenites hiatus

Thomsonipollis magnificus

Tilia vescipites

Tricolpites spp.

Triporopollenites spp.

Trudopollis pertrudens

Pediastrum sp.

unidentified trilete spore

unidentified dinocyst

D9154-H

Caryapollenites veripites [relatively abundant]

Caryapollenites wodehousei

Cicatricosisporites sp.

Laevigatosporites $\mathrm{sp}$.

Momipites coryloides

Momipites triradiatus

Momipites ventifluminis

Nyssapollenites sp.

Pityosporites sp. 
Sernapollenites duratus

Simplicepollis rallus

Sparganiaceaepollenites sp.

Taxodiaceaepollenites hiatus [relatively abundant]

Tricolpites spp.

Triporopollenites spp.

Ulmipollenites sp.

Pediastrum sp. [relatively abundant]

D9154-K

Arecipites spp.

Corollina sp.

Laevigatosporites sp.

Liliacidites sp.

Momipites coryloides

Momipites tenuipolus

Nyssapollenites sp.

"Palaeoisoetes" sp.

Sernapollenites duratus

Simplicepollis rallus

Stereisporites spp.

Taxodiaceaepollenites hiatus

Thomsonipollis magnificus

"Tricolpopollenites baculoferus"

Triporopollenites spp.

Ulmipollenites $\mathrm{sp}$.

Zlivisporis sp.

D9154-M

Arecipites spp.

Caryapollenites veripites

Caryapollenites wodehousei

Chenopodipollis sp.

Corollina sp.

Laevigatosporites spp.

Momipites coryloides

Momipites ventifluminis

"Palaeoisoetes" sp.

Pistillipollenites mcgregorii

Pityosporites $\mathrm{sp}$.

Stereisporites spp.

Taxodiaceaepollenites hiatus

Thomsonipollis magnificus

Triporopollenites spp.

Ulmipollenites sp.

Schizophacus sp. 


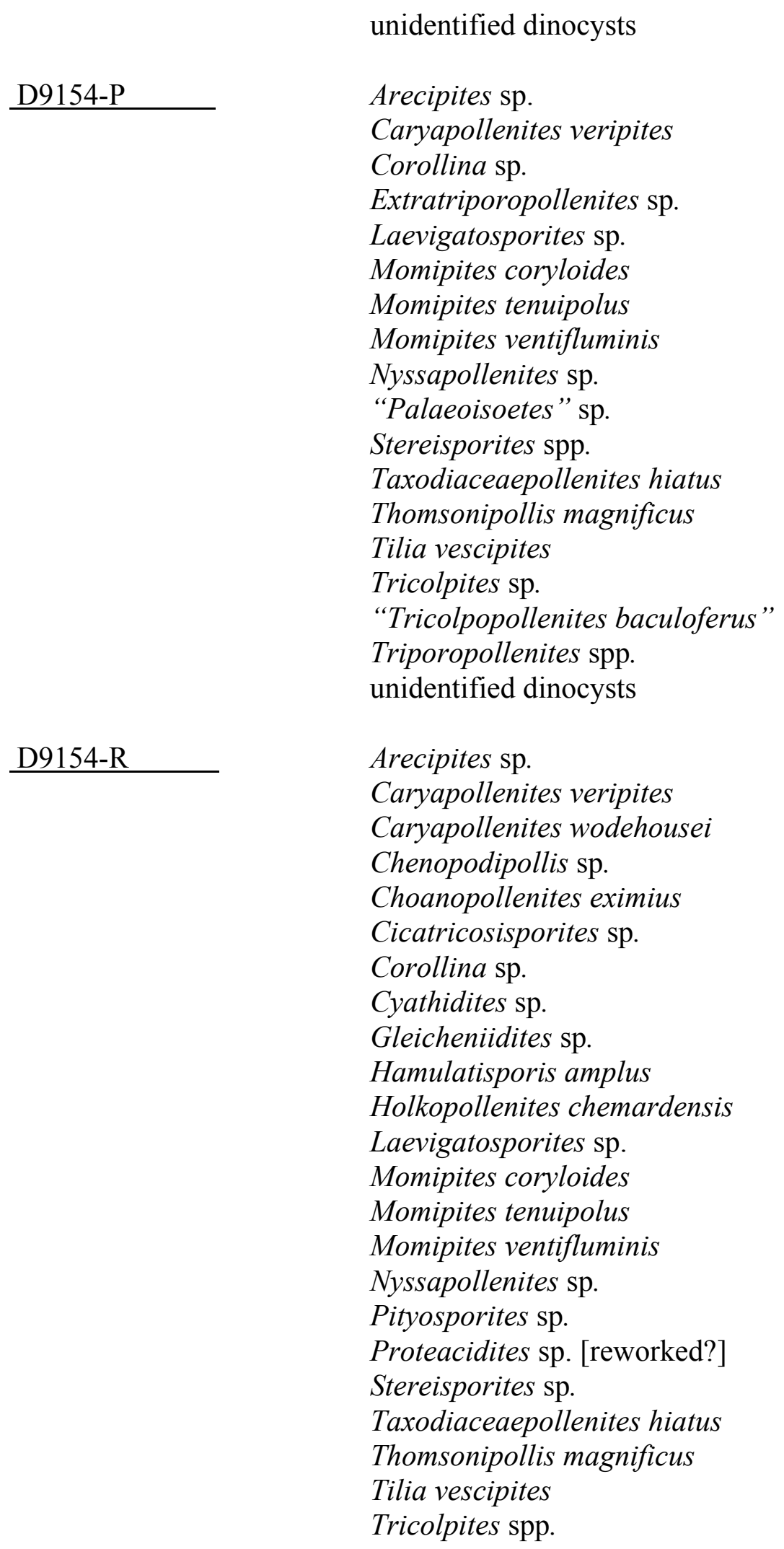


Triporopollenites spp.

Ulmipollenites sp.

unidentified acritarch

unidentified dinocysts [fairly common]

D9154-T

D9154-V

D9154-W
Caryapollenites veripites

Cyathidites sp.

Laevigatosporites sp.

Momipites coryloides

Momipites ventifluminis

Nyssapollenites sp.

Quadrapollenites vagus

Reticuloidosporites pseudomurii

Rhoipites sp.

Sparganiaceaepollenites $\mathrm{sp}$.

Stereisporites spp.

Taxodiaceaepollenites hiatus

Thomsonipollis magnificus

Tilia vescipites

Tricolpites spp.

"Tricolpopollenites baculoferus"

Triporopollenites spp.

unidentified dinocysts

Chenopodipollis sp.

Cicatricosisporites sp.

Extratriporopollenites sp.

Momipites actinus

Momipites ventifluminis

Nyssapollenites sp.

Pityosporites spp.

Retitriletes sp. ("Lycopodiumsporites")

Stereisporites spp.

Taxodiaceaepollenites hiatus

Thomsonipollis magnificus

Tricolpites sp.

Triporopollenites spp.

unidentified dinocysts

Arecipites sp.

Cicatricosisporites sp.

Hamulatisporis amplus

Momipites dilatus

Momipites tenuipolus 
Nudopollis terminalis [relatively abundant]

Pityosporites sp.

Sernapollenites duratus

Stereisporites spp.

Taxodiaceaepollenites hiatus

Thomsonipollis magnificus

Tricolpites spp.

Triporopollenites spp. [common] 
Table 3. Palynology Sample Index, Borehole USGS-PA-1

[Note abbreviations: clyst=claystone, $\arg =$ argillaceous, mudst=mudstone, sltst=siltstone, carb sh=carbonaceous shale]

Field No. $\quad$ Lab No. $\quad$ Depth (ft)

Remarks (as of 6/21/04)

Sampled in field (Hotel pre-shipping)

$\begin{array}{rrl}\text { PA-1.1 } & \text { D9153-A } & 128.7-129.8 \\ \text { PA-1.2 } & \text {-B } & 129.8-130.7 \\ \text { PA-1.3 } & \text {-C } & 130.7-132.8 \\ \text { PA-1.4 } & \text {-D } & 331.0-334.0(\sim 331.20 ?) \\ \text { PA-1.5 } & \text {-E } & 334.0-337.0 \\ \text { PA-1.6 } & \text {-F } & 337.0-340.0 \\ \text { PA-1.7 } & \text {-G } & 340.0-343.0 \\ \text { PA-1.8 } & \text {-H } & 343.0-346.0 \\ \text { PA-1.9 } & \text {-I } & 346.0-347.7\end{array}$

Sampled at Texas A\&M storage

$\begin{array}{lrcl}\text { PA-1-A } & \text { D9154-A } & 19.8-19.9 & \text { clyst; processed and examined } \\ \text { PA-1-B } & \text {-B } & \text { ca } 27.0-27.25 & \text { coal; not processed } \\ \text { PA-1-C } & \text {-C } & 31.9-32.0 & \text { clyst; not processed } \\ \text { PA-1-D } & \text {-D } & 38.0-38.1 & \text { mudst; processed and examined } \\ \text { PA-1-E } & \text {-E } & 66.0-66.1 & \text { sltst; not processed } \\ \text { PA-1-F } & \text {-F } & 83.5-83.6 & \text { sltst; processed and examined } \\ \text { PA-1-G } & \text {-G } & 85.3-85.4 & \text { sltst; not processed } \\ \text { PA-1-H } & \text {-H } & 97.7-97.8 & \text { arg ss; processed and examined } \\ \text { PA-1-I } & \text {-I } & 112.85-113.0 & \text { coal; not processed } \\ \text { PA-1-J } & \text {-J } & 133.0-133.1 & \text { clyst; not processed } \\ \text { PA-1-K } & \text {-K } & 138.0-138.1 & \text { clyst; processed and examined } \\ \text { PA-1-L } & \text {-L } & 155.7-155.8 & \text { carb sh; not processed } \\ \text { PA-1-M } & \text {-M } & 179.9-180.0 & \text { clyst; processed and examined } \\ \text { PA-1-N } & \text {-N } & 182.8-183.6 & \text { mudst; not processed } \\ \text { PA-1-O } & \text {-O } & 183.7-183.8 & \text { clyst; not processed } \\ \text { PA-1-P } & \mathbf{- P} & 184.7-184.8 & \text { clyst; processed and examined } \\ \text { PA-1-Q } & \mathbf{- Q} & 198.0-198.1 & \text { mudst; not processed } \\ \text { PA-1-R } & \mathbf{- R} & 209.5-209.6 & \text { clyst; processed and examined } \\ \text { PA-1-S } & \mathbf{- S} & 225.9-226.0 & \text { clyst; not processed } \\ \text { PA-1-T } & \mathbf{- T} & 239.8-239.9 & \text { clyst; processed and examined } \\ \text { PA-1-U } & \mathbf{- U} & 297.9-298.0 & \text { clyst; not processed } \\ \text { PA-1-V } & \mathbf{- V} & 318.0-318.1 & \text { clyst; processed and examined } \\ \text { PA-1-W } & \mathbf{- W} & 330.5-330.6 & \text { coal; processed and examined } \\ & & & \end{array}$


Plate 1. Photomicrographs of pollen from core USGS-PA-1

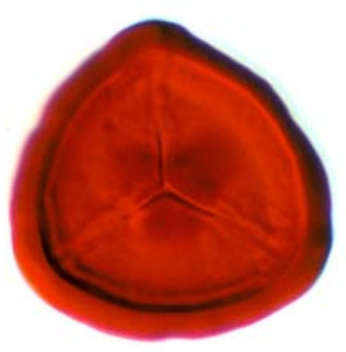

Stereisporites sp.

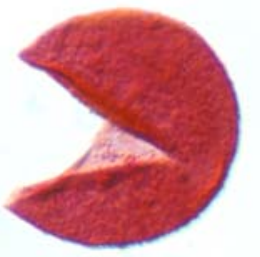

Taxodiaceaepollenites hiatus

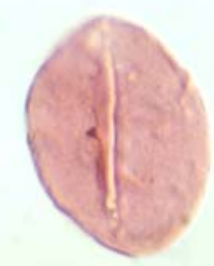

Arecipites sp. 1

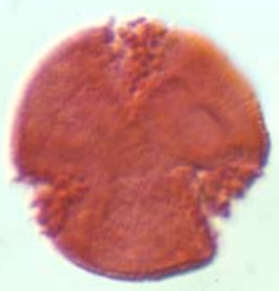

Tricolpites sp. 1

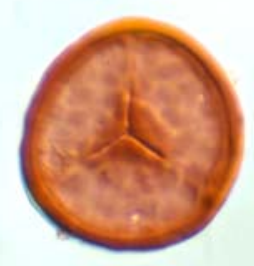

Stereisporites sp.
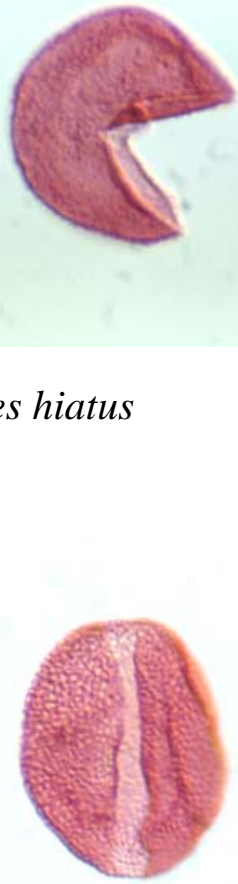

Arecipites sp. 2

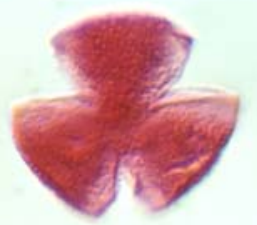

Tricolpites sp. 2
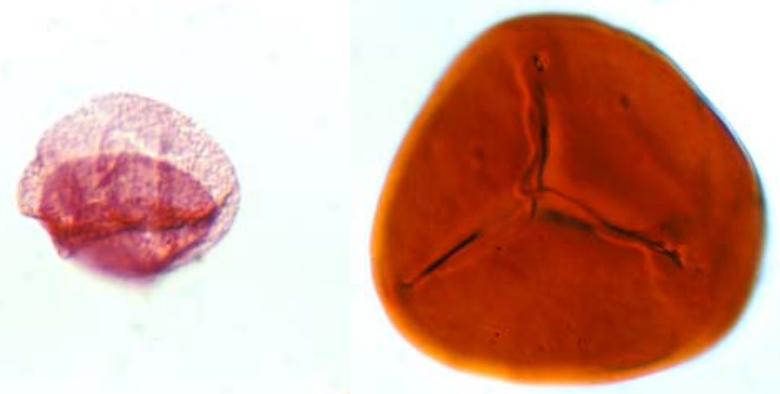

Deltoidospora sp.
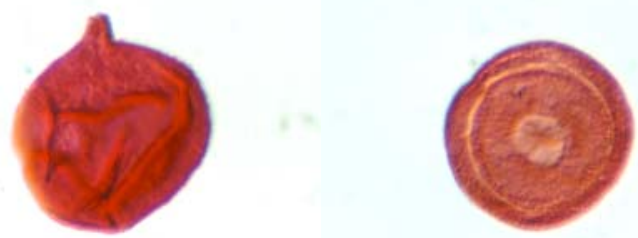

Sequoiapollenites sp.

Corollina sp.
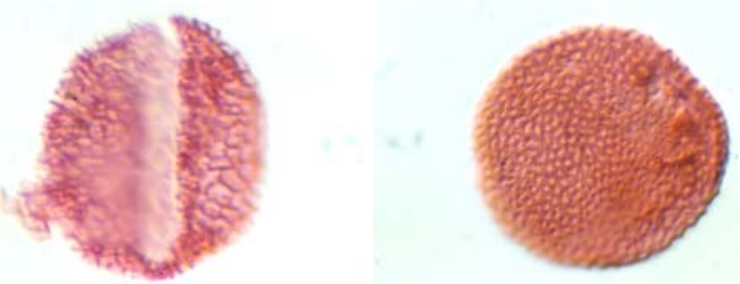

Liliacidites sp. Sparganiaceaepollenites sp.
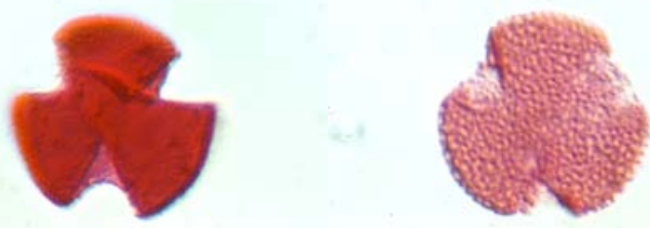

Tricolpites sp. 3

Tricolpites sp. 4 


\section{POLLEN SAMPLES FROM CORE USGS-PA-2}

This is the final report on palynological analyses of samples from USGS Core PA-2, Panola County, Texas (lat $31^{\circ} 58^{\prime} 58.21^{\prime \prime}$, long $\left.94^{\circ} 09^{\prime} 07.05^{\prime \prime}\right)$. This report covers 11 rock samples from the core collected in the field in June 1999 (see Table 6). Interpretations of age and depositional environments are provided in Table 4 and lists of palynomorphs in Table 5. Species lists contribute toward compilation of a palynostratigraphic database for the Gulf Coast Tertiary.

On the basis of fossil pollen species known to be key palynostratigraphic guide fossils in the Rocky Mountain region, the ages of samples from this core range from middle to late Paleocene. Results from analyses of these samples constitute clear indication that palynostratigraphic zones well documented in the Rocky mountain region are applicable also to the Gulf Coast region.

Several of these samples yielded marine dinoflagellate cysts (dinocysts). Their presence is indicative of marine influence in the depositional environment, although the assemblages from all samples are overwhelmingly of nonmarine origin, and freshwater algal cysts are present in some samples. Such mixed assemblages of palynomorphs could occur in rocks deposited in estuarine depositional environments; the other samples appear to represent overbank deposits associated with coal-depositional environments.

Table 4. Age and depositional environment of selected samples from core USGS-PA-2.

$\begin{array}{llll}\text { Sample } & \text { Depth (ft) } & \text { Lithology } & \text { Results } \\ \text { D9152-A } & 52.9-53.0 & \text { gray claystone } & \begin{array}{l}\text { The sample yielded a diverse palynomorph } \\ \text { assemblage indicative of late Paleocene age. } \\ \text { The assemblage is composed predominantly } \\ \text { of terrestrial pollen, but includes freshwater } \\ \text { algae. }\end{array} \\ \text { D9152-C } & 97.8-98.0 & \begin{array}{l}\text { laminated gray } \\ \text { siltstone }\end{array} & \begin{array}{l}\text { Assemblage dominated by terrestrial pollen } \\ \text { and spores indicative of late Paleocene age } \\ \text { but including dinoflagellate cysts } \\ \text { (dinocysts) and acritarchs indicative of } \\ \text { marine influence in the depositional } \\ \text { environment. }\end{array} \\ \text { D9152-F } & 134.0-134.2 & \begin{array}{l}\text { olive green to } \\ \text { gray siltstone }\end{array} & \begin{array}{l}\text { Diverse assemblage of terrestrial pollen } \\ \text { and spores indicative of late Paleocene age; }\end{array}\end{array}$


also includes freshwater algae (common) and marine dinocysts.

\begin{tabular}{|c|c|c|c|}
\hline D9152-I & $140.0-140.2$ & $\begin{array}{l}\text { carbonaceous } \\
\text { shale with leaf } \\
\text { marine } \\
\text { fragments }\end{array}$ & $\begin{array}{l}\text { Low-diversity assemblage with two co- } \\
\text { dominant fern-spore species. No } \\
\text { influence noted. }\end{array}$ \\
\hline D9152-J & $161.2-161.6$ & $\begin{array}{l}\text { carbonaceous } \\
\text { claystone }\end{array}$ & $\begin{array}{l}\text { Sparse, low-diversity assemblage including } \\
\text { one late Paleocene guide species. }\end{array}$ \\
\hline D9152-K & $249.9-250.0$ & $\begin{array}{l}\text { "chocolate" } \\
\text { siltstone }\end{array}$ & $\begin{array}{l}\text { Diverse assemblage of terrestrial pollen and } \\
\text { spores. No freshwater or marine } \\
\text { palynomorphs present. No late Paleocene } \\
\text { guide species present; guide species present } \\
\text { indicate mid-Paleocene age (comparable to } \\
\text { palynostratigraphic Zone P4 in the Rocky } \\
\text { Mountain region). }\end{array}$ \\
\hline D9152-M & $255.1-255.3$ & $\begin{array}{l}\text { carbonaceous } \\
\text { shale }\end{array}$ & $\begin{array}{l}\text { Exceedingly sparse assemblage presumably } \\
\text { of Paleocene age. No marine species } \\
\text { observed. }\end{array}$ \\
\hline D9152-N & $319.2-319.3$ & $\begin{array}{l}\text { olive-black } \\
\text { claystone }\end{array}$ & $\begin{array}{l}\text { Diverse assemblage evidently of mid- } \\
\text { Paleocene age. Marine dinocysts present, } \\
\text { indicating marine influence in depositional } \\
\text { environment. }\end{array}$ \\
\hline D9152-O & $338.6-338.7$ & $\begin{array}{l}\text { carbonaceous } \\
\text { silty claystone }\end{array}$ & $\begin{array}{l}\text { Assemblage evidently of mid-Paleocene } \\
\text { age. No marine species observed. }\end{array}$ \\
\hline D9152-S & $375.6-375.7$ & $\begin{array}{l}\text { carbonaceous } \\
\text { shale or dirty coal }\end{array}$ & $\begin{array}{l}\text { Sparse assemblage evidently of mid- } \\
\text { Paleocene age. No marine influence } \\
\text { detected. }\end{array}$ \\
\hline D9152-U & $394.5-394.6$ & $\begin{array}{l}\text { laminated olive } \\
\text { siltstone }\end{array}$ & $\begin{array}{l}\text { Diverse assemblage clearly of mid- } \\
\text { Paleocene age. Marine dinocysts and } \\
\text { acritarchs are present. }\end{array}$ \\
\hline
\end{tabular}

Note that the mid-Paleocene to late Paleocene transition is within the interval bracketed by samples at about 162 and $250 \mathrm{ft}$ in this core. 
Table 5. List of palynomorphs for selected samples from core USGS-PA-2.

\section{Sample}

D9152-A

D9152-C

D9152-F

\section{Palynomorphs}

Arecipites sp.

Caryapollenites veripites [dominant among Jugl. pollen]

Caryapollenites wodehousei

Cicatricosisporites sp.

Cyathidites sp.

Laevigatosporites sp.

Liliacidites $\mathrm{sp}$.

Momipites coryloides

Momipites ventifluminis

Nyssapollenites sp.

"Palaeoisoetes" sp.

Pityosporites sp.

Rhoipites sp.

Sequoiapollenites sp.

Sernapollenites duratus

Sparganiaceaepollenites sp.

Stereisporites spp.

Taxodiaceaepollenites hiatus

Thomsonipollis magnificus

Toroisporis sp.

Tricolpites spp.

Triporopollenites spp.

Ulmipollenites sp.

Pediastrum sp.

Caryapollenites veripites

Caryapollenites wodehousei

Chenopodipollis sp.

Laevigatosporites sp.

Momipites coryloides

Momipites ventifluminis

Myocolpopollenites reticulatus

"Palaeoisoetes" sp.

Pityosporites sp.

Taxodiaceaepollenites hiatus

Toroisporis sp.

Tricolpites sp.

Triporopollenites spp.

Ulmipollenites $\mathrm{sp}$.

marine acritarch (Baltisphaeridium sp.)

marine dinocysts [unidentified]

Basopollis basalis 
Caryapollenites inelegans

Caryapollenites veripites [dominant among Jugl. pollen]

Caryapollenites wodehousei

Deltoidospora sp.

Holkopollenites chemardensis

Laevigatosporites $\mathrm{sp}$.

Liliacidites sp.

Momipites coryloides

Momipites triradiatus

Momipites ventifluminis

Nyssapollenites sp.

Pistillipollenites mcgregorii

Rhoipites sp.

Sernapollenites duratus

Stereisporites sp.

Taxodiaceaepollenites hiatus

Thomsonipollis magnificus

Tricolpites spp.

"Tricolpopollenites" baculoferus

Triporopollenites spp.

Ulmipollenites sp.

Pediastrum sp. [common]

marine dinocysts [unidentified]

D9152-I

Deltoidospora sp.

Laevigatosporites sp. [common]

Pistillipollenites mcgregorii

Taxodiaceaepollenites hiatus

Thomsonipollis magnificus

Tilia vescipites

Toroisporis sp. [common]

Triporopollenites spp.

D9152-J

Caryapollenites veripites

Thomsonipollis magnificus

Stereisporites sp.

Triporopollenites spp.

D9152-K

Alnus speciipites

Aquilapollenites spinulosus 
Arecipites spp.

Basopollis basalis

Bombacacidites sp.

Caryapollenites wodehousei

Chenopodipollis sp.

Cicatricosisporites sp.

Gleicheniidites sp.

Holkopollenites chemardensis

Insulapollenites rugulatus

Laevigatosporites spp.

Liliacidites $\mathrm{sp}$.

Momipites actinus

Momipites coryloides

Momipites tenuipolus

Momipites triletipollenites

Momipites triorbicularis

Momipites ventifluminis

Nudopollis terminalis

Nyssapollenites spp.

Pityosporites sp.

Retitriletes sp. ("Lycopodiumsporites")

Rhoipites spp.

Simplicepollis rallus

Stereisporites spp.

Taxodiaceaepollenites hiatus

Thomsonipollis magnificus

Tricolpites sp. cf. T. hians [common]

Tricolpites spp.

Triporopollenites spp.

Trudopollis pertrudens

Ulmipollenites sp.

Momipites tenuipolus

Momipites sp.

Taxodiaceaepollenites hiatus

Tricolpites sp.

Triporopollenites sp. 
D9152-N

D9152-O
Alnus speciipites

Basopollis basalis

Cicatricosisporites sp.

Cyathidites sp.

Insulapollenites rugulatus

Laevigatosporites $\mathrm{sp}$.

Momipites tenuipolus

Momipites ventifluminis

Nudopollis terminalis

Nyssapollenites sp.

Osmundacidites $\mathrm{sp}$.

Pandaniidites sp.

Pityosporites sp.

Reticuloidosporites pseudomurii

Taxodiaceaepollenites hiatus

Thomsonipollis magnificus

Tilia vescipites

Triporopollenites spp.

Trudopollis pertrudens

Stereisporites spp.

acritarch [unidentified]

marine dinocysts [unidentified]

Alnus speciipites

Basopollis basalis

Cicatricosisporites sp.

Laevigatosporites $\mathrm{sp}$.

Lygodiumsporites $\mathrm{sp}$.

Momipites tenuipolus

Nudopollis terminalis

Nyssapollenites sp.

Osmundacidites $\mathrm{sp}$.

Retitriletes sp. ("Lycopodiumsporites")

Rhoipites sp.

Taxodiaceaepollenites hiatus

Thomsonipollis magnificus

Toroisporis sp.

Tricolpites $\mathrm{sp}$.

Triporopollenites spp.

Stereisporites spp. 
D9152-S

D9152-U
Alnus speciipites

Laevigatosporites sp.

Momipites coryloides

Momipites tenuipolus

Nyssapollenites sp.

Taxodiaceaepollenites hiatus

Tricolpites spp.

Alnipollenites scoticus

Alnus speciipites

Aquilapollenites spinulosus

Arecipites sp.

Chenopodipollis sp.

Erdtmanipollis sp.

Laevigatosporites $\mathrm{sp}$.

Momipites actinus

Momipites tenuipolus

Nyssapollenites sp.

Pityosporites spp.

Retitriletes sp. ("Lycopodiumsporites")

Stereisporites spp.

Taxodiaceaepollenites hiatus

Thomsonipollis magnificus

Tricolpites spp.

Triporopollenites spp.

Ulmipollenites sp.

marine acritarchs including Pterospermella sp.

marine dinocysts [unidentified] 
Table 6. Palynology Sample Index, Borehole USGS-PA-2 (All Sampled on site)

\begin{tabular}{|c|c|c|c|}
\hline Field No. & Lab No. & Depth (ft) & Remarks (as of 6/21/04) \\
\hline PA-2-A & D9152-A & $52.9-53.0$ & clyst; processed and examined \\
\hline PA-2-B & $-\mathbf{B}$ & $96.3-96.5$ & coal; processed - not examined \\
\hline PA-2-C & $-\mathrm{C}$ & $97.8-98.0$ & sltst; processed and examined \\
\hline PA-2-D & $-\mathbf{D}$ & 107.9-108.0 & sltst; not processed \\
\hline PA-2-E & $-\mathbf{E}$ & $115.2-115.3$ & clyst; not processed \\
\hline PA-2-F & $-\mathbf{F}$ & $134.0-134.2$ & sltst; processed and examined \\
\hline PA-2-G & $-G$ & $137.9-138.0$ & clyst; not processed \\
\hline PA-2-H & $-\mathbf{H}$ & $138.2-138.4$ & coal; processed - not examined \\
\hline PA-2-I & $-\mathbf{I}$ & $140.0-140.2$ & carb sh; processed and examined \\
\hline PA-2-J & $-\mathbf{J}$ & 161.2-161.6 & clyst; processed and examined \\
\hline PA-2-K & $-\mathbf{K}$ & $249.9-250.0$ & sltst; processed and examined \\
\hline PA-2-L & $-\mathbf{L}$ & $251.9-252.1$ & coal; not processed \\
\hline PA-2-M & $-\mathbf{M}$ & $255.1-255.3$ & carb sh; processed and examined \\
\hline PA-2-N & $-\mathbf{N}$ & 319.2-319.3 & clyst; processed and examined \\
\hline PA-2-O & $-\mathbf{O}$ & $338.6-338.7$ & clyst; processed and examined \\
\hline PA-2-P & $-\mathbf{P}$ & $346.6-346.7$ & clyst; not processed \\
\hline PA-2-Q & $-\mathbf{Q}$ & $365.0-365.1$ & coal; processed - not examined \\
\hline PA-2-R & $-\mathbf{R}$ & ca. $373 \mathrm{ft}$ & coal; not processed \\
\hline PA-2-S & $-\mathbf{S}$ & $375.6-375.7$ & carb sh; processed and examined \\
\hline PA-2-T & $-\mathbf{T}$ & $378.6-378.7$ & sltst; not processed \\
\hline PA-2-U & $-\mathbf{U}$ & $394.5-394.6$ & sltst; processed and examined \\
\hline
\end{tabular}


Plate 2. Photomicrographs of pollen from core USGS-PA-2

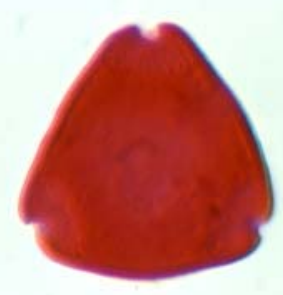

Momipites sp.

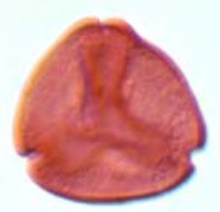

M. triradiatus

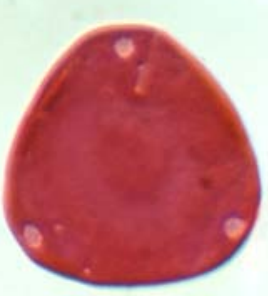

C. inelegans

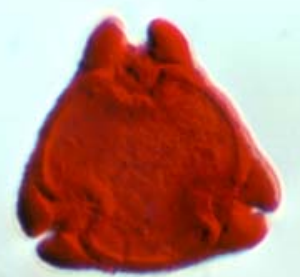

Trudopollis pertrudens

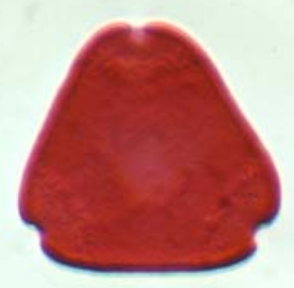

Momipites sp.

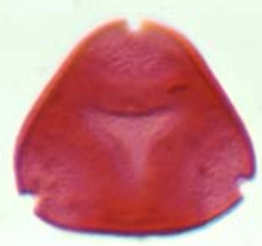

M. actinus

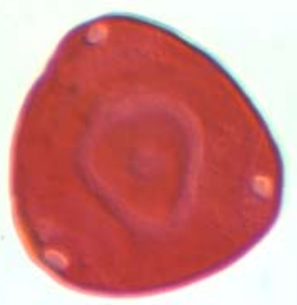

C. veripites

C. veripites

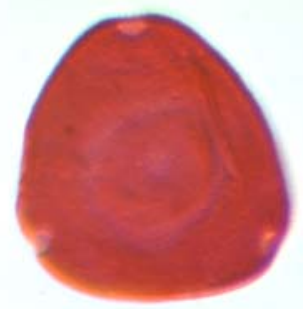

Caryapollenites prodromus
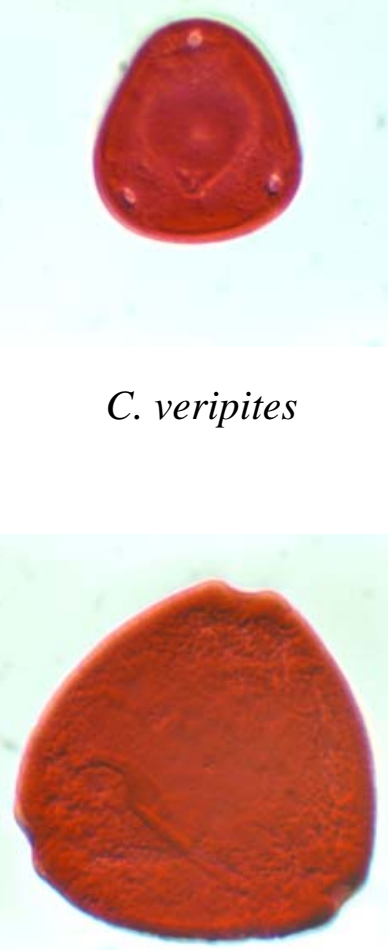

Triporopollenites sp.

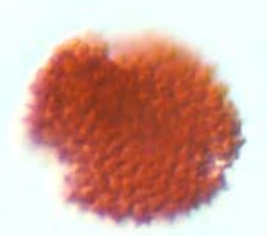

Sernapollenites duratus

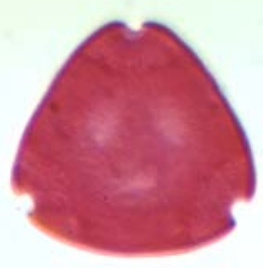

M. ventifluminis

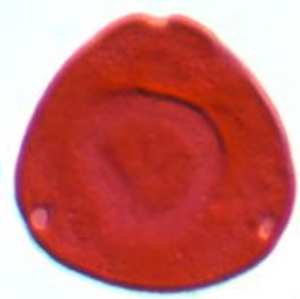

C. wodehousei

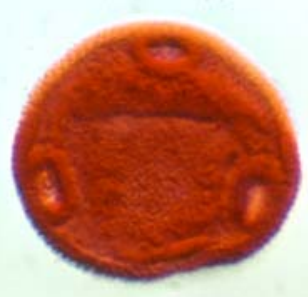

Thomsonipollis magnificus

Alnus speciipites 


\section{Chapter 7}

\section{Dinocyst data from borehole USGS-PA-2}

By Lucy E. Edwards ${ }^{2}$

Chapter 7 of

Results of coalbed methane drilling in Panola County, Texas

Edited By Peter D. Warwick', John R. SanFilipo', Alex W. Karlsen', and Charles E. Barker ${ }^{2}$

'U.S. Geological Survey, Reston, VA

'U.S. Geological Survey, Denver, CO

Open-File Report 2005-1046

U.S. Department of the Interior

U.S. Geological Survey 


\section{DINOCYST SAMPLES FROM CORE USGS-PA-2}

This chapter summarizes marine dinoflagellate studies on samples from core USGS-PA-2, Panola County, Texas, lat. 31 deg., 58'57.03” N, long. 94 deg., 09'07.38'W (GPS), elevation $253 \mathrm{ft}$ (estimated from topographic map). Processing was completed on all 23 samples taken. However, twelve samples were selected for examination.

All but one sample contained dinocysts, although no sample contained abundant dinocysts. Pollen is present in all. Nearly all studied samples contained dinocysts of Cretaceous age that are presumed to be reworked. The freshwater alga, Pediastrum, is present in most samples. Preservation is fair to poor.

Samples from 393.7 to $277.0 \mathrm{ft}$ (uncorrected depth, corrected depths are provided in Chapter 2) are dominated by species of Spinidinium and miscellaneous peridiniacean forms. These are generally not age-diagnostic, although the samples resemble those reported in the literature from the Paleocene Cannonball Formation in South Dakota (Stanley, 1965). The environment of deposition is marine, but most likely nearshore to estuarine.

Samples from 231.0 to $57.1 \mathrm{ft}$ (uncorrected depth, corrected depths are provided in Chapter 2) contain members of the Apectodinium homomorphum (Deflandre \& Cookson) Lentin \& Williams species-complex. This complex has its lowest stratigraphic occurrence in the late Paleocene (Thanetian) in strata that have been correlated to calcareous nannofossil Zone NP 9 or possibly NP 8. A single, questionably identified specimen of Damassadinium californicum (Drugg) Fensome et al. restricts the age to Paleocene. The environment of deposition is marine, but most likely nearshore.

The pollen from PA-2 should be studied in conjunction with the dinoflagellates in order to determine the extent of the reworking. Many of the samples, especially in the lower part of the core, contain no dinocysts that restrict the age, other than the Cretaceous dinocysts. Further study is needed to determine whether these samples are:

(1) Cretaceous in age, marine,

(2) Tertiary in age, nonmarine, with extensive Cretaceous reworking, or

(3) Tertiary in age, marginal marine, with less extensive reworking.

Full information to date is given in Table 1 and Figure 1. 


\section{Table 1. Dinocyst data on selected samples from core USGS-PA-2}

R6141 A (393.5-393.7 ft depth)

Preservation: fair. Diversity: moderately low. Dominated by small peridiniacean forms (not a lot of dinocyst specimens).

Age: includes Cretaceous material, probably both Early and Late.

Environment: Includes marine (but marginal/nearshore) dinocysts that may or may not be in place.

Fibrocysta Stover \& Evitt sp.

Chatangiella Vozzhennikova sp.

Cribroperidinium Neale \& Sarjeant? sp.

Muderongia Cookson \& Eisenack? sp.

Senegalinium microgranulatum (Stanley) Stover \& Evitt

Spinidinium styloniferum Cookson \& Eisenack

Spinidinium Cookson \& Eisenack sp.

Spiniferites Mantell spp.

Spongodinium delitiense (Ehrenberg) Deflandre

miscellaneous areoligeracean forms

small peridiniacean forms

freshwater alga Pediastrum

R6141 B (377.1-377.5 ft depth)

Preservation: fair. Diversity: moderately low. No particular species dominant (not a lot of dinocyst specimens).

Age: includes Late Cretaceous material.

Environment: Includes marine (but marginal/nearshore) dinocysts that may or may not be in place.

Chatangiella Vozzhennikova? sp.

Cordosphaeridium Eisenack sp.

Oligosphaeridium Davey \& Williams sp.

Senegalinium microgranulatum (Stanley) Stover \& Evitt

Spinidinium Cookson \& Eisenack sp.

Spiniferites Mantell spp.

Spongodinium delitiense (Ehrenberg) Deflandre

miscellaneous areoligeracean forms

small peridiniacean forms

freshwater alga Pediastrum

R6141 C (355.2-355.4 ft depth)

Preservation: fair. Diversity: moderately low. No particular species dominant (not a lot of dinocyst specimens).

Age: includes Late Cretaceous material.

Environment: Includes marine (but marginal/nearshore) dinocysts that may or may not be in place.

Isabelidinium Lentin \& Williams? sp.

Oligosphaeridium Davey \& Williams spp.

Operculodinium Wall sp.

Palaeohystrichophora infusorioides Deflandre 
Palaeoperindinium Deflandre sp.

Senegalinium microgranulatum (Stanley) Stover \& Evitt

Spinidinium densispinaturm Stanley

Spinidinium Cookson \& Eisenack spp.

Spiniferites Mantell spp.

Spongodinium delitiense (Ehrenberg) Deflandre ?

miscellaneous areoligeracean form ?

small peridiniacean forms

freshwater alga Pediastrum

R6141 D (345.8-346.0 ft depth)

Preservation: poor. Diversity: low. Dominated by small peridiniacean forms (not a lot of dinocyst specimens).

Age: includes Late Cretaceous material.

Environment: Includes marine (but marginal/nearshore) dinocysts that may or may not be in place.

Chatangiella Vozzhennikova sp.

Hystrichosphaeridium Deflandre sp.

Odontochitina Deflandre? sp.

Palaeocystodinium golzowense Alberti

Palaeohystrichophora infusorioides Deflandre

Spinidinium Cookson \& Eisenack spp.

Spiniferites Mantell spp.

small peridiniacean forms

freshwater alga Pediastrum

R6141 E (331.5-331.7 ft depth)

Preservation: fair. Diversity: low. Dominated by small peridiniacean forms (not a lot of dinocyst specimens).

Age: includes Late Cretaceous material.

Environment: Includes marine (but marginal/nearshore) dinocysts that may or may not be in place.

Chatangiella Vozzhennikova? sp.

Hystrichosphaeridium tubiferum (Ehrenberg) Deflandre

Operculodinium Wall sp.

Palaeocystodinium Alberti ? sp.

Palaeoperidinium Deflandre sp.

Spinidinium densispinaturm Stanley

Spinidinium Cookson \& Eisenack sp.

Spiniferites Mantell spp.

small peridiniacean forms

R6141 H (277.0-277.2 ft depth)

Preservation: poor. Diversity: low. Dominated by small peridiniacean forms (not a lot of dinocyst specimens).

Age: includes Late Cretaceous material.

Environment: Includes marine (but marginal/nearshore) dinocysts that may or may not be in place. 
Chatangiella Vozzhennikova sp.

Palaeoperidinium pyrophorum (Ehrenberg) Sarjeant

Phelodinium magnificum (Stanley) Stover \& Evitt

Spinidinium densispinaturm Stanley

Spinidinium Cookson \& Eisenack sp.

Spiniferites Mantell sp.

miscellaneous areoligeracean forms

small peridiniacean forms

freshwater alga Pediastrum

R6141 J (258.9-259.0 ft depth)

Preservation: fair. No dinocysts observed.

Age: unknown

Environment: presumably nonmarine.

R6141 L (230.8-231.0 ft depth)

Preservation: poor to fair. Diversity: low. No particular species dominant.

Age: late Paleocene or Eocene.

Environment: Marginal or nearshore marine.

Apectodinium homomorphum (Deflandre \& Cookson) Lentin \& Williams complex

Fibrocysta radiata (Morgenroth) Stover \& Evitt

Hystrichosphaeridium Deflandre? sp.

Polysphaeridium subtile Davey \& Williams

Spinidinium Cookson \& Eisenack sp.

Spiniferites pseudofurcatus (Klumpp) Sarjeant?

Spiniferites Mantell sp.

Thalassiphora delicata Williams \& Downie

small peridiniacean forms

freshwater alga Pediastrum

R6141 N (186.8-187.0 ft depth)

Preservation: fair to poor. Diversity: low. No particular species dominant (not a lot of dinocyst specimens).

Age: late Paleocene ? with Late Cretaceous reworked material

[Note absence of small peridiniaceans and Spinidiniums.]

Environment: Nearshore marine.

Apectodinium homomorphum (Deflandre \& Cookson) Lentin \& Williams complex

Chatangiella verrucosa (Manum) Lentin \& Williams

Damassadinium californicum (Drugg) Fensome et al. ?

Diphyes colligerum (Deflandre \& Cookson) Cookson

Palaeohystrichophora infusorioides Deflandre

Spiniferites pseudofurcatus (Klumpp) Sarjeant

Spiniferites Mantell spp.

miscellaneous areoligeracean form

freshwater alga Pediastrum

R6141 R (130.7-130.9 ft depth) 
Preservation: fair to poor. Diversity: low. No particular species dominant (not a lot of dinocyst specimens).

Age: late Paleocene or Eocene with Late Cretaceous reworked material

[Note absence of small peridiniaceans and Spinidiniums.]

Environment: Nearshore marine.

Apectodinium homomorphum (Deflandre \& Cookson) Lentin \& Williams complex

Chatangiella Vozzhennikova sp.

Cordosphaeridium Eisenack sp.

Cribroperidinium Neale \& Sarjeant sp.

Eocladopyxis peniculata Morgenroth ??

Operculodinium Wall sp.

Spiniferites pseudofurcatus (Klumpp) Sarjeant

Spiniferites Mantell spp.

Spongodinium delitiense (Ehrenberg) Deflandre ??

miscellaneous areoligeracean form

freshwater alga Pediastrum

R6141 V (57.1-57.3 ft depth)

Preservation: fair. Diversity: low. No particular species dominant (not a lot of dinocyst specimens).

Age: late Paleocene or Eocene with Late Cretaceous reworked material

[Note absence of Spinidiniums, but not small peridiniaceans.]

Environment: Nearshore marine.

Apectodinium homomorphum (Deflandre \& Cookson) Lentin \& Williams complex

Chatangiella verrucosa (Manum) Lentin \& Williams

Exochosphaeridium Davey et al. sp.

Isabelidinium Lentin \& Williams sp.

Operculodinium Wall sp.

Spiniferites Mantell spp.

Trithyrodinium Drugg sp.

miscellaneous areoligeracean forms

small peridiniacean forms

freshwater alga Pediastrum

R6141 W (32.8-33.1 ft depth)

Preservation: poor. Diversity: very low. One specimen observed

Age: unknown

Environment: unknown 


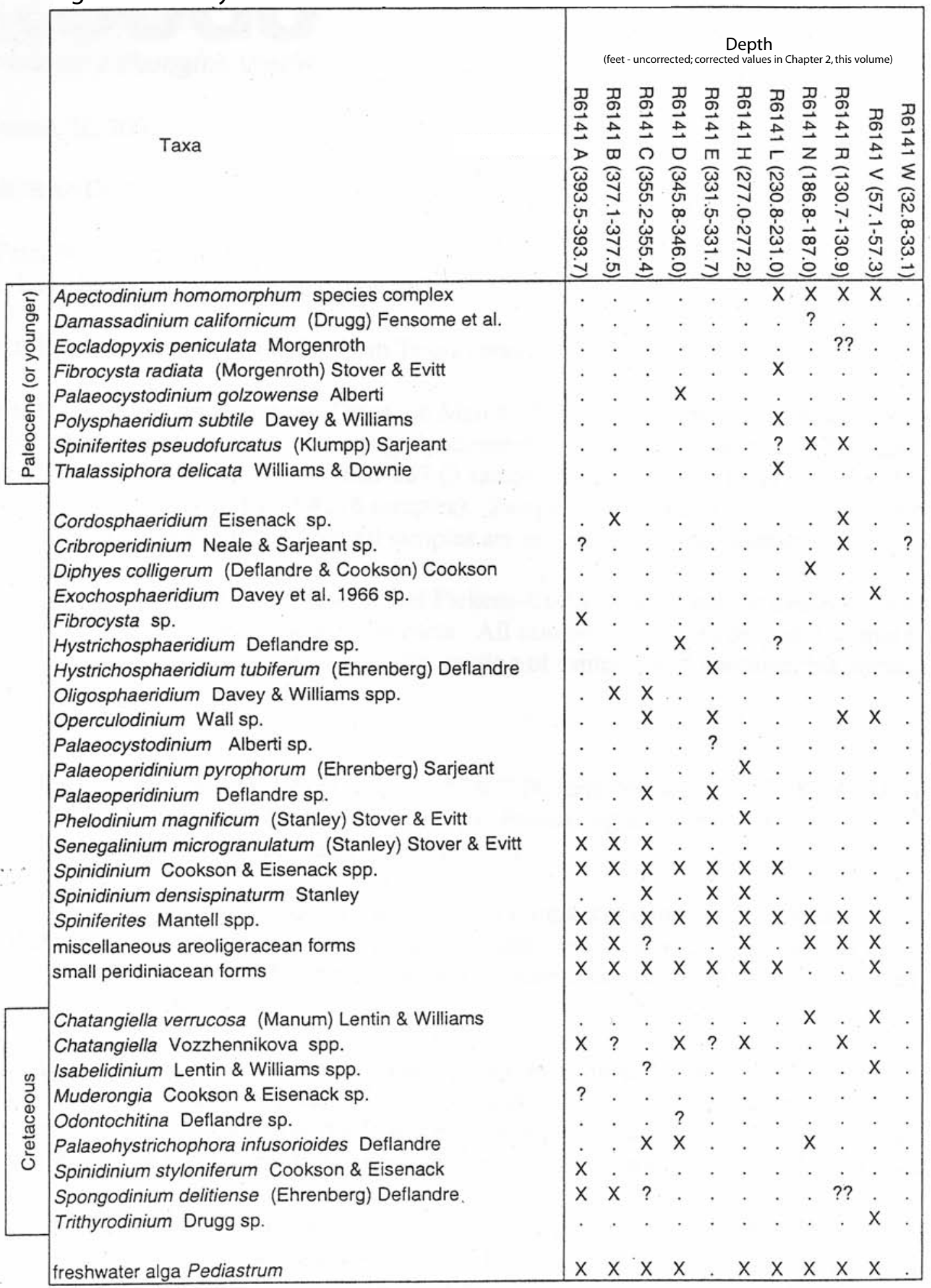




\section{Chapter 8}

\section{Methane desorption data from borehole USGS-PA-2}

By Charles E. Barker', and Ronnie Tingook ${ }^{2}$

Chapter 8 of

Results of coalbed methane drilling in Panola County, Texas

Edited By Peter D. Warwick', John R. SanFilipo', Alex W. Karlsen', and Charles E. Barker ${ }^{2}$

'U.S. Geological Survey, Reston, VA

${ }^{2}$ U.S. Geological Survey, Denver, CO

Open-File Report 2005-1046

U.S. Department of the Interior

U.S. Geological Survey 


\section{Introduction}

The following Excel spreadsheets and graphs present methane desorption field data from timed measurements of pressure, volume, and temperature that are corrected to standard pressure and temperature (STP) using methods following Barker and others (2002). Corrected depths for the samples are listed in Chapter 2, and do not match this chapter. Lost gas estimate values were interpreted from graphical representations of the cumulative desorped volume of gas from each sample canister. A "best-fit" line was manually adjusted to the initial slope of the cumulative gas volume curves to extrapolate back to time zero to determine the estimated volume of lost gas. Appendix 7 provides links to the raw data files for these figures and tables.

\section{References Cited}

Barker, C.E., Dallegge, T.A., and Clark, A.C., 2002, USGS Coal desorption equipment and a spreadsheet for analysis of lost and total gas from canister desorption measurements: U.S. Geological Survey Open-File Report 02-496, un-paginated. http://pubs.usgs.gov/of/2002/ofr-02-496/ 


\section{Cumulative Gas Desorbed (cc) \\ (USGS-PA-2-CN1)}

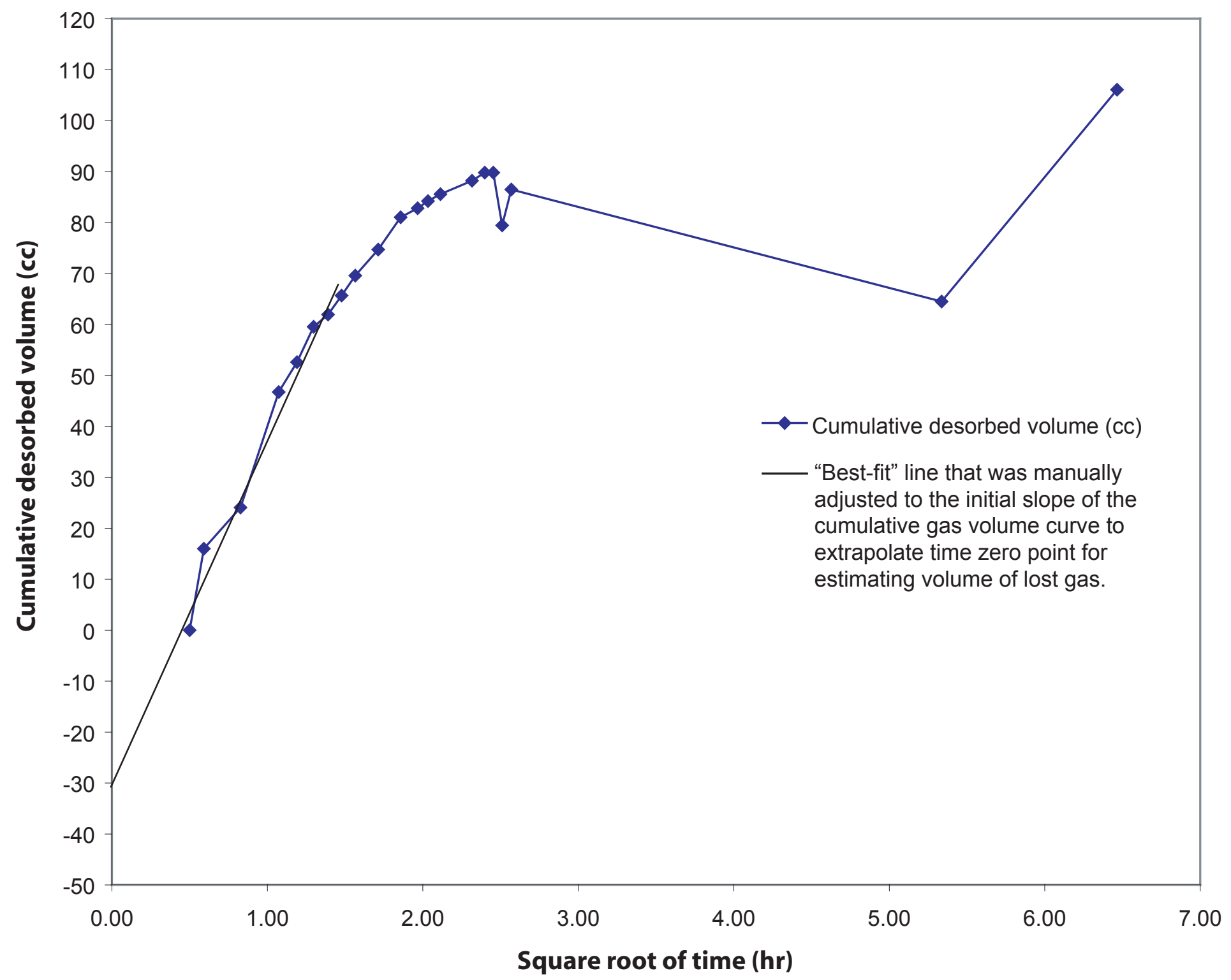

Lost Gas Estimate $=30 \mathrm{cc}$

Raw Total Gas $=\quad 0.13 \mathrm{~g} / \mathrm{cc}(4.19 \mathrm{SCF} / \mathrm{ton})$

DAF Total Gas $=\quad 0.28 \mathrm{~g} / \mathrm{cc}(7.68 \mathrm{SCF} /$ ton $)$

g/cc - grams per cubic centimeter

SCF/Ton - Standard Cubic Feet per ton

Figure 1 
Table 1

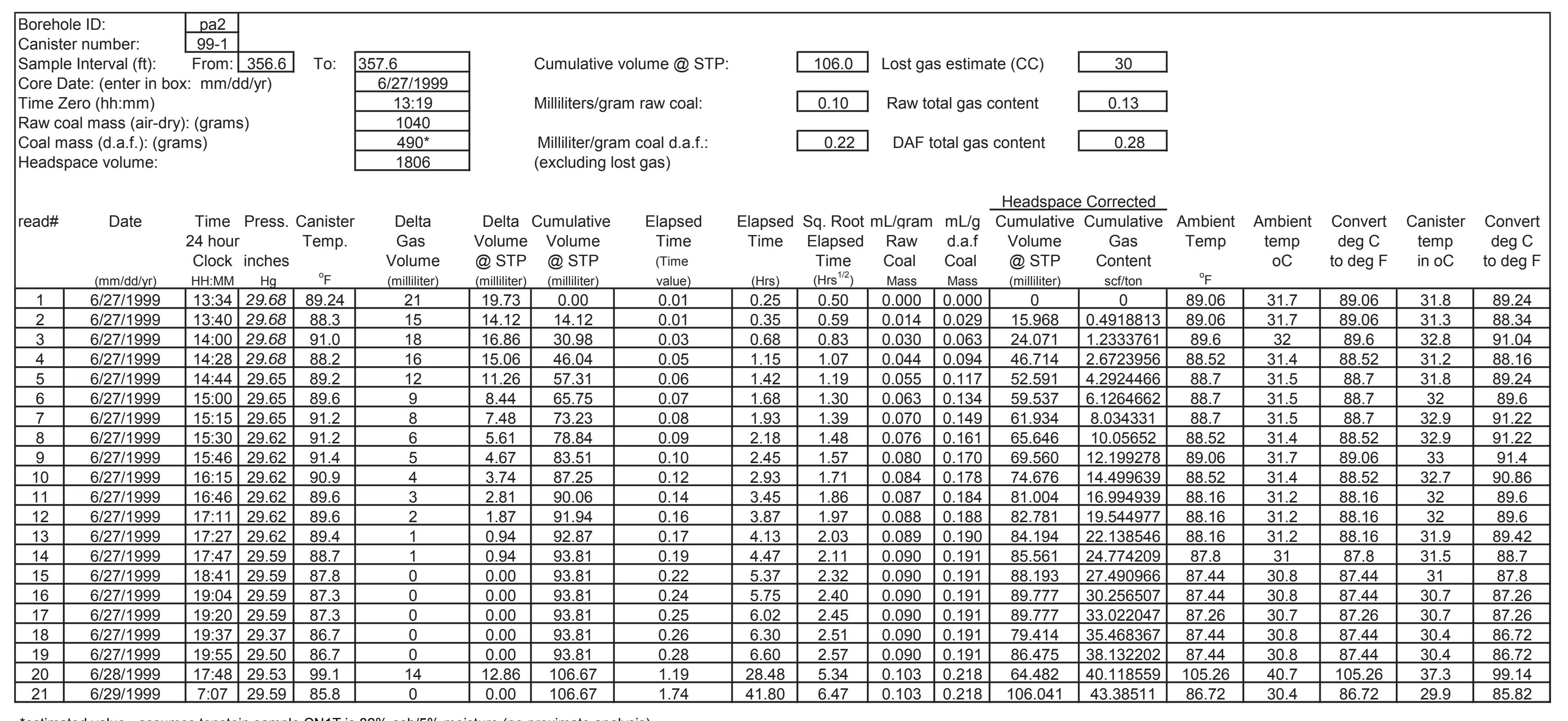




\section{Cumulative Gas Desorbed (cc) \\ (USGS-PA-2-CN2)}

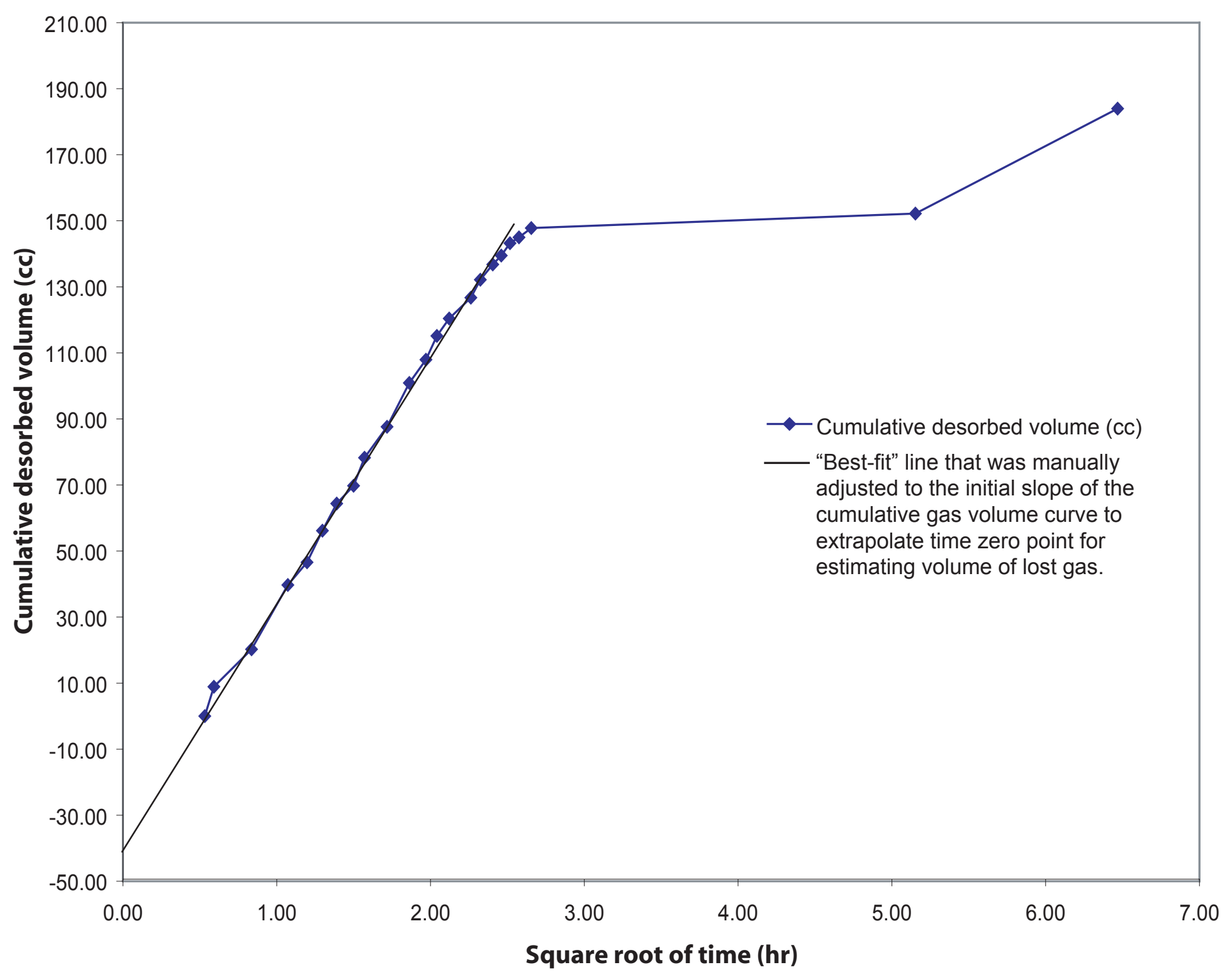

Lost Gas Estimate $=40 \mathrm{cc}$

Raw Total Gas $=\quad 0.21 \mathrm{~g} / \mathrm{cc}(6.62 \mathrm{SCF} / \mathrm{ton})$

DAF Total Gas $=\quad 0.34 \mathrm{~g} / \mathrm{cc}(10.78 \mathrm{SCF} / \mathrm{ton})$

g/cc - grams per cubic centimeter

SCF/Ton - Standard Cubic Feet per ton

Figure 2 


\section{Table 2}

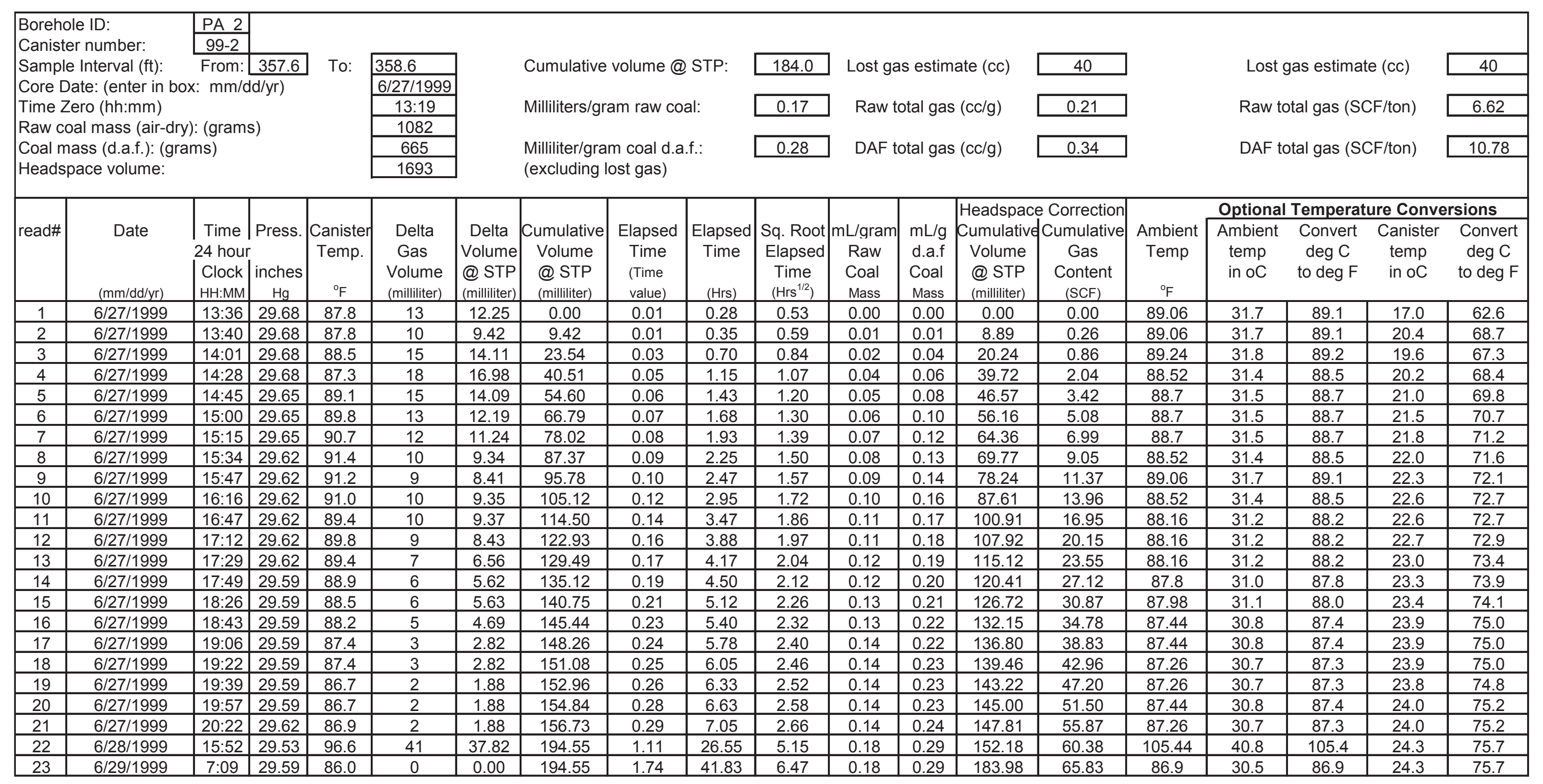




\section{Cumulative Gas Desorbed (cc) \\ (USGS-PA-2-CN3)}

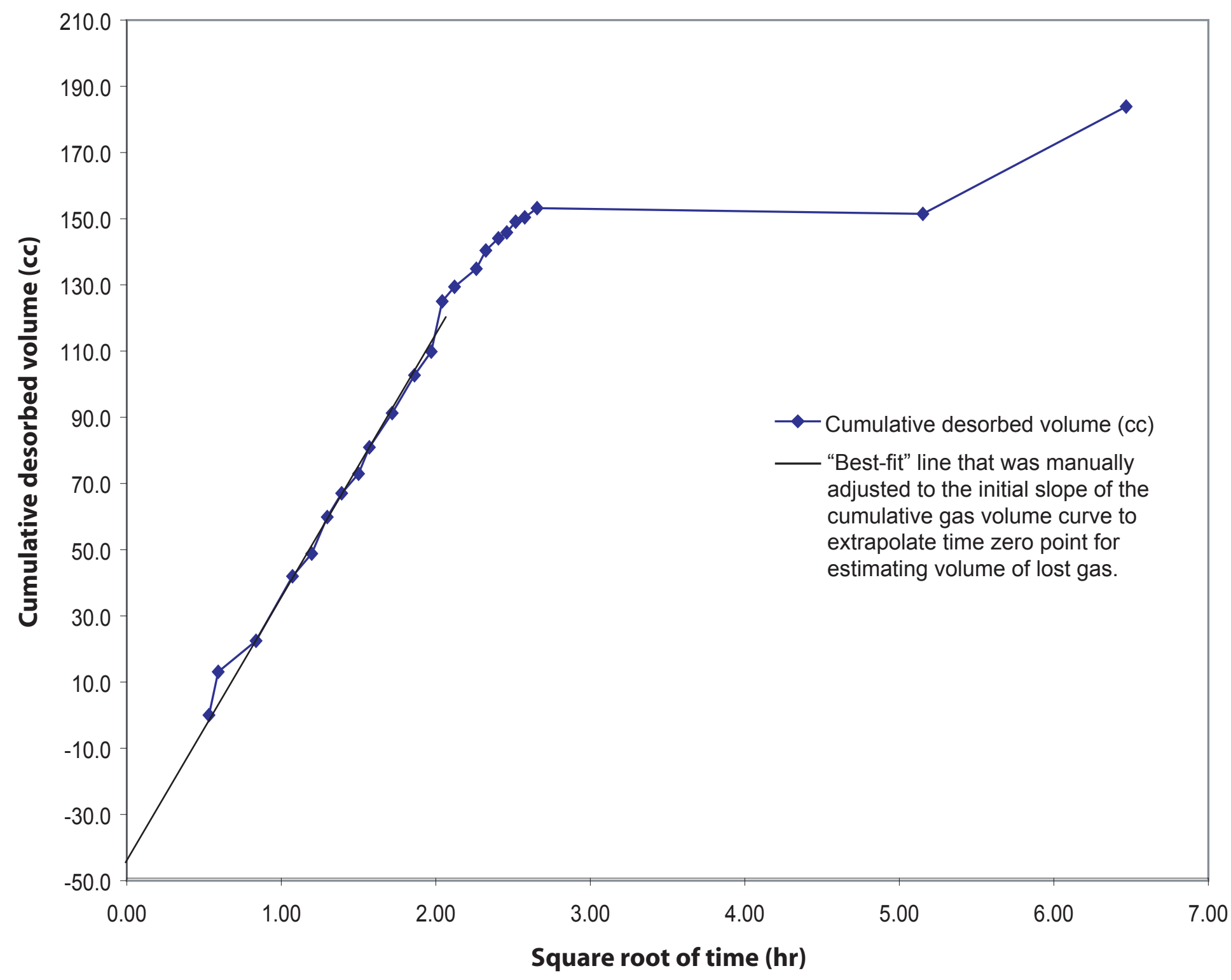

Lost Gas Estimate $=45 \mathrm{cc}$

Raw Total Gas $=\quad 0.22 \mathrm{~g} / \mathrm{cc}(6.92 \mathrm{SCF} / \mathrm{ton})$

DAF Total Gas $=\quad 0.36 \mathrm{~g} / \mathrm{cc}(11.39 \mathrm{SCF} / \mathrm{ton})$

g/cc - grams per cubic centimeter

SCF/Ton - Standard Cubic Feet per ton

Figure 3 


\section{Table 3}

\begin{tabular}{|c|c|c|c|c|c|c|c|c|c|c|c|c|c|c|c|c|c|c|c|}
\hline $\begin{array}{l}\text { Project } \\
\text { Well ID }\end{array}$ & $\frac{\text { Wilc }}{\text { PA }}$ & & Can no. & $99-3$ & & & & & & & & & & & & & & & \\
\hline Sample & Interval (ft): & From: & 358.6 & To: & 359.6 & & Cumulative & volume @ & STP: & 183.9 & Lost ga & as estima & ate (cc) & 45.00 & & Raw to & tal gas (SC & F/ton) & 6.92 \\
\hline $\begin{array}{l}\text { Core Da } \\
\text { Time Ze }\end{array}$ & $\begin{array}{l}\text { ate: (enter in } \\
\text { ero (hh:mm) }\end{array}$ & ox: $\mathrm{mm} / \mathrm{c}$ & dd/yr) & & \begin{tabular}{|c|}
$6 / 27 / 1999$ \\
$13: 19$ \\
\end{tabular} & & Milliliters/gra & am raw coa & & 0.17 & Raw $t$ & otal gas & $(\mathrm{cc} / \mathrm{g})$ & 0.22 & & DAF to & tal gas (SC & CF/ton) & 11.39 \\
\hline Raw co & al mass (air- & ry): (gram & & & 1058 & & & & & & & & & & & & & & \\
\hline Coal ma & ass (d.a.f.): ( & rams) & & & 643.00 & & Milliliter/gran & n coal d.a. & & 0.29 & DAF $t$ & otal gas & (cc/g) & 0.36 & & & & & \\
\hline & & & & & & & & & & & & & Headspac & e Correction & & Optional & Temperat & ure Conve & rsions \\
\hline & $(\mathrm{mm} / \mathrm{dd} / \mathrm{yr})$ & $\begin{array}{l}\text { Time } \\
24 \text { hour } \\
\text { Clock } \\
\text { HH:MM } \\
\end{array}$ & $\begin{array}{c}\text { Pressure } \\
\text { inches } \\
\mathrm{Hg}\end{array}$ & $\begin{array}{c}\text { Canister } \\
\text { Temp. } \\
{ }^{\circ} \mathrm{F} \\
\end{array}$ & $\begin{array}{l}\text { Delta } \\
\text { Gas } \\
\text { Volume } \\
\text { (milliliter) }\end{array}$ & $\begin{array}{l}\text { Delta } \\
\text { Volume } \\
@ \text { STP } \\
\text { (milliliter) }\end{array}$ & $\begin{array}{c}\text { Cumulative } \\
\text { Volume } \\
@ \text { STP } \\
\text { (milliliter) }\end{array}$ & $\begin{array}{c}\text { Elapsed } \\
\text { Time } \\
\text { (Time } \\
\text { value) }\end{array}$ & 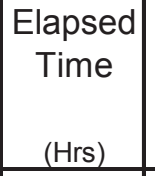 & $\begin{array}{c}\text { Sq. Root } \\
\text { Elapsed } \\
\text { Time } \\
\left(\mathrm{Hrs}^{1 / 2}\right) \\
\end{array}$ & \begin{tabular}{|c|} 
ml/gram \\
Raw \\
Coal \\
Mass \\
\end{tabular} & $\begin{array}{l}\mathrm{ml} / \mathrm{g} \\
\text { d.a.f } \\
\text { Coal } \\
\text { Mass }\end{array}$ & $\begin{array}{c}\text { Cumulative } \\
\text { Volume } \\
@ \text { STP } \\
\text { (milliliter) }\end{array}$ & $\begin{array}{c}\text { Cumulative } \\
\text { Gas } \\
\text { Content } \\
(\mathrm{SCF})\end{array}$ & $\begin{array}{c}\text { Ambient } \\
\text { Temp } \\
{ }^{\circ} \mathrm{F} \\
\end{array}$ & $\begin{array}{c}\text { Ambient } \\
\text { temp } \\
\text { in oC }\end{array}$ & $\begin{array}{c}\text { Convert } \\
\operatorname{deg} \mathrm{C} \\
\text { to } \operatorname{deg} \mathrm{F}\end{array}$ & $\begin{array}{c}\text { Canister } \\
\text { temp } \\
\text { in oC }\end{array}$ & $\begin{array}{l}\text { Convert } \\
\text { deg } \mathrm{C} \\
\text { to } \operatorname{deg} \mathrm{F}\end{array}$ \\
\hline 1 & $6 / 27 / 1999$ & $13: 36$ & 29.68 & 86.7 & 8 & 7.55 & 0.00 & 0.01 & 0.28 & 0.53 & 0.00 & 0.00 & 0.0 & 0.0 & 89.1 & 31.7 & 89.1 & 30.4 & 86.7 \\
\hline 2 & $6 / 27 / 1999$ & $13: 40$ & 29.68 & 87.4 & 17 & 16.03 & 16.03 & 0.01 & 0.35 & 0.59 & 0.02 & 0.02 & 13.1 & 0.4 & 89.1 & 31.7 & 89.1 & 30.8 & 87.4 \\
\hline 3 & $6 / 27 / 1999$ & $14: 01$ & 29.68 & 88.9 & 15 & 14.10 & 30.13 & 0.03 & 0.70 & 0.84 & 0.03 & 0.05 & 22.5 & 1.1 & 89.2 & 31.8 & 89.2 & 31.6 & 88.9 \\
\hline 4 & $6 / 27 / 1999$ & $14: 28$ & 29.68 & 87.6 & 18 & 16.96 & 47.10 & 0.05 & 1.15 & 1.07 & 0.04 & 0.07 & 42.0 & 2.3 & 88.5 & 31.4 & 88.5 & 30.9 & 87.6 \\
\hline 5 & $6 / 27 / 1999$ & $14: 45$ & 29.65 & 89.4 & 15 & 14.08 & 61.17 & 0.06 & 1.43 & 1.20 & 0.06 & 0.10 & 48.8 & 3.8 & 88.7 & 31.5 & 88.7 & 31.9 & 89.4 \\
\hline 6 & $6 / 27 / 1999$ & $15: 00$ & 29.65 & 89.6 & 13 & 12.20 & 73.37 & 0.07 & 1.68 & 1.30 & 0.07 & 0.11 & 59.8 & 5.6 & 88.7 & 31.5 & 88.7 & 32.0 & 89.6 \\
\hline 7 & $6 / 27 / 1999$ & $15: 15$ & 29.65 & 90.9 & 12 & 11.23 & 84.60 & 0.08 & 1.93 & 1.39 & 0.08 & 0.13 & 67.1 & 7.7 & 88.7 & 31.5 & 88.7 & 32.7 & 90.9 \\
\hline 8 & $6 / 27 / 1999$ & $15: 34$ & 29.62 & 91.4 & 10 & 9.34 & 93.94 & 0.09 & 2.25 & 1.50 & 0.09 & 0.15 & 72.9 & 9.9 & 88.5 & 31.4 & 88.5 & 33.0 & 91.4 \\
\hline 9 & $6 / 27 / 1999$ & $15: 47$ & 29.62 & 91.4 & 9 & 8.41 & 102.35 & 0.10 & 2.47 & 1.57 & 0.10 & 0.16 & 80.9 & 12.3 & 89.1 & 31.7 & 89.1 & 33.0 & 91.4 \\
\hline 10 & $6 / 27 / 1999$ & $16: 16$ & 29.62 & 90.9 & 10 & 9.35 & 111.70 & 0.12 & 2.95 & 1.72 & 0.11 & 0.17 & 91.3 & 15.1 & 88.5 & 31.4 & 88.5 & 32.7 & 90.9 \\
\hline 11 & $6 / 27 / 1999$ & $16: 47$ & 29.62 & 89.6 & 9 & 8.43 & 120.13 & 0.14 & 3.47 & 1.86 & 0.11 & 0.19 & 102.7 & 18.2 & 88.2 & 31.2 & 88.2 & 32.0 & 89.6 \\
\hline 12 & $6 / 27 / 1999$ & $17: 12$ & 29.62 & 89.6 & 8 & 7.50 & 127.63 & 0.16 & 3.88 & 1.97 & 0.12 & 0.20 & 109.8 & 21.5 & 88.2 & 31.2 & 88.2 & 32.0 & 89.6 \\
\hline 13 & $6 / 27 / 1999$ & $17: 29$ & 29.62 & 89.2 & 16 & 15.00 & 142.64 & 0.17 & 4.17 & 2.04 & 0.13 & 0.22 & 125.0 & 25.3 & 88.2 & 31.2 & 88.2 & 31.8 & 89.2 \\
\hline 14 & $6 / 27 / 1999$ & $17: 49$ & 29.59 & 88.7 & 5 & 4.69 & 147.33 & 0.19 & 4.50 & 2.12 & 0.14 & 0.23 & 129.4 & 29.2 & 87.8 & 31.0 & 87.8 & 31.5 & 88.7 \\
\hline 15 & $6 / 27 / 1999$ & $18: 26$ & 29.59 & 88.3 & 5 & 4.69 & 152.02 & 0.21 & 5.12 & 2.26 & 0.14 & 0.24 & 134.9 & 33.3 & 88.0 & 31.1 & 88.0 & 31.3 & 88.3 \\
\hline 16 & $6 / 27 / 1999$ & $18: 43$ & 29.59 & 87.6 & 4 & 3.76 & 155.78 & 0.23 & 5.40 & 2.32 & 0.15 & 0.24 & 140.4 & 37.6 & 87.4 & 30.8 & 87.4 & 30.9 & 87.6 \\
\hline 17 & $6 / 27 / 1999$ & 19:06 & 29.59 & 87.3 & 3 & 2.82 & 158.60 & 0.24 & 5.78 & 2.40 & 0.15 & 0.25 & 144.1 & 41.9 & 87.4 & 30.8 & 87.4 & 30.7 & 87.3 \\
\hline 18 & $6 / 27 / 1999$ & $19: 22$ & 29.59 & 87.3 & 2 & 1.88 & 160.48 & 0.25 & 6.05 & 2.46 & 0.15 & 0.25 & 145.8 & 46.3 & 87.3 & 30.7 & 87.3 & 30.7 & 87.3 \\
\hline 19 & $6 / 27 / 1999$ & $19: 39$ & 29.59 & 86.7 & 2 & 1.88 & 162.36 & 0.26 & 6.33 & 2.52 & 0.15 & 0.25 & 149.1 & 50.9 & 87.3 & 30.7 & 87.3 & 30.4 & 86.7 \\
\hline 20 & $6 / 27 / 1999$ & $19: 57$ & 29.59 & 86.9 & 2 & 1.88 & 164.24 & 0.28 & 6.63 & 2.58 & 0.16 & 0.26 & 150.4 & 55.4 & 87.4 & 30.8 & 87.4 & 30.5 & 86.9 \\
\hline 21 & $6 / 27 / 1999$ & $20: 22$ & 29.62 & 87.1 & 2 & 1.88 & 166.12 & 0.29 & 7.05 & 2.66 & 0.16 & 0.26 & 153.2 & 60.1 & 87.4 & 30.8 & 87.4 & 30.6 & 87.1 \\
\hline 22 & $6 / 28 / 1999$ & $15: 52$ & 29.53 & 96.8 & 34 & 31.36 & 197.48 & 1.11 & 26.55 & 5.15 & 0.19 & 0.31 & 151.5 & 64.6 & 105.1 & 40.6 & 105.1 & 36.0 & 96.8 \\
\hline 23 & $6 / 29 / 1999$ & $7: 09$ & 29.59 & 86.0 & 0 & 0.00 & 197.48 & 1.74 & 41.83 & 6.47 & 0.19 & 0.31 & 183.9 & 70.2 & 86.9 & 30.5 & 86.9 & 30.0 & 86.0 \\
\hline
\end{tabular}




\section{Cumulative Gas Desorbed (cc) \\ (USGS-PA-2-CN4)}

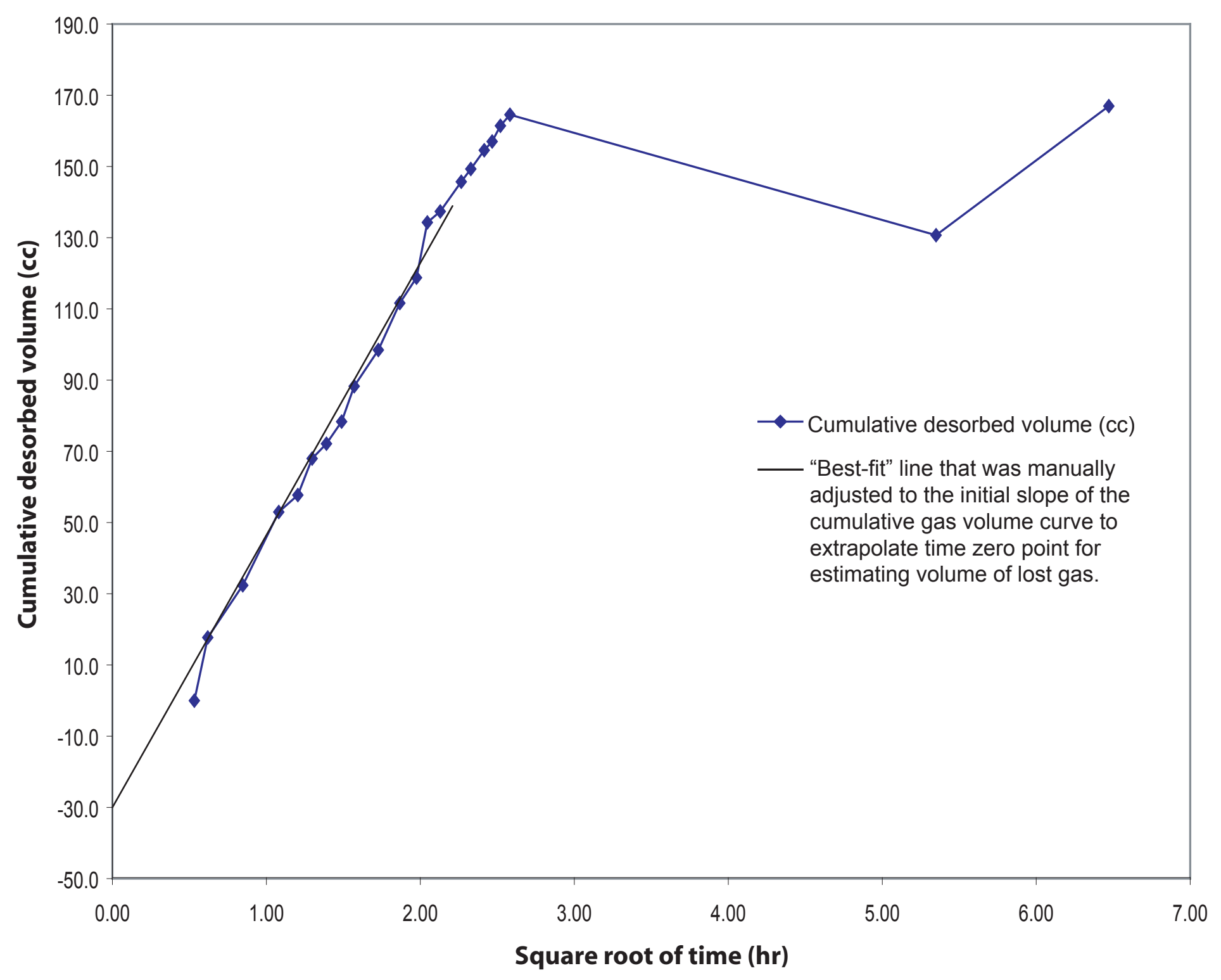

Lost Gas Estimate $=30 \mathrm{cc}$

Raw Total Gas $=\quad 0.64 \mathrm{~g} / \mathrm{cc}(20.46 \mathrm{SCF} / \mathrm{ton})$

DAF Total Gas $=\quad 1.05 \mathrm{~g} / \mathrm{cc}(33.53 \mathrm{SCF} /$ ton $)$

g/cc - grams per cubic centimeter

SCF/Ton - Standard Cubic Feet per ton

Figure 4 


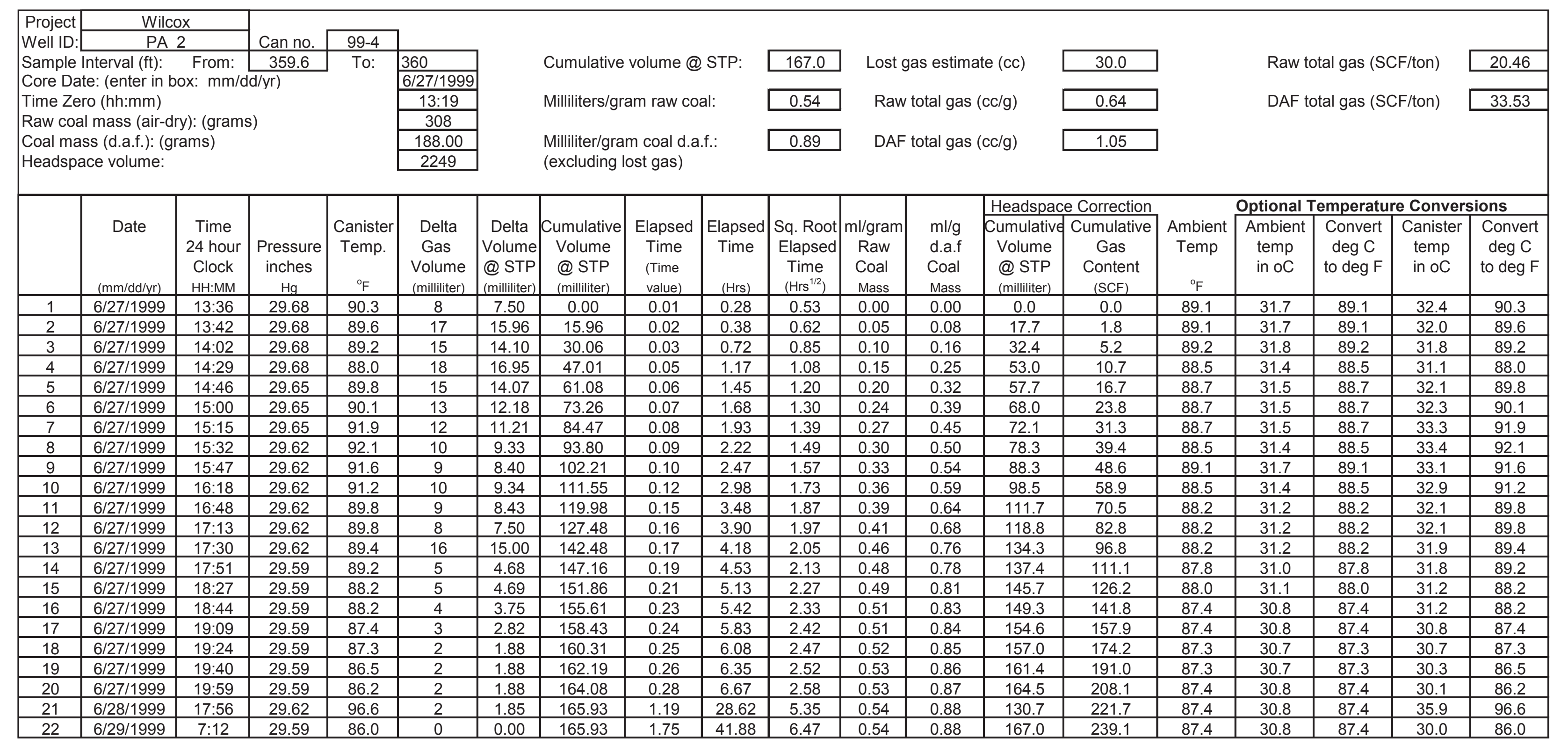




\section{Cumulative Gas Desorbed (cc) \\ (USGS-PA-2-CN5)}

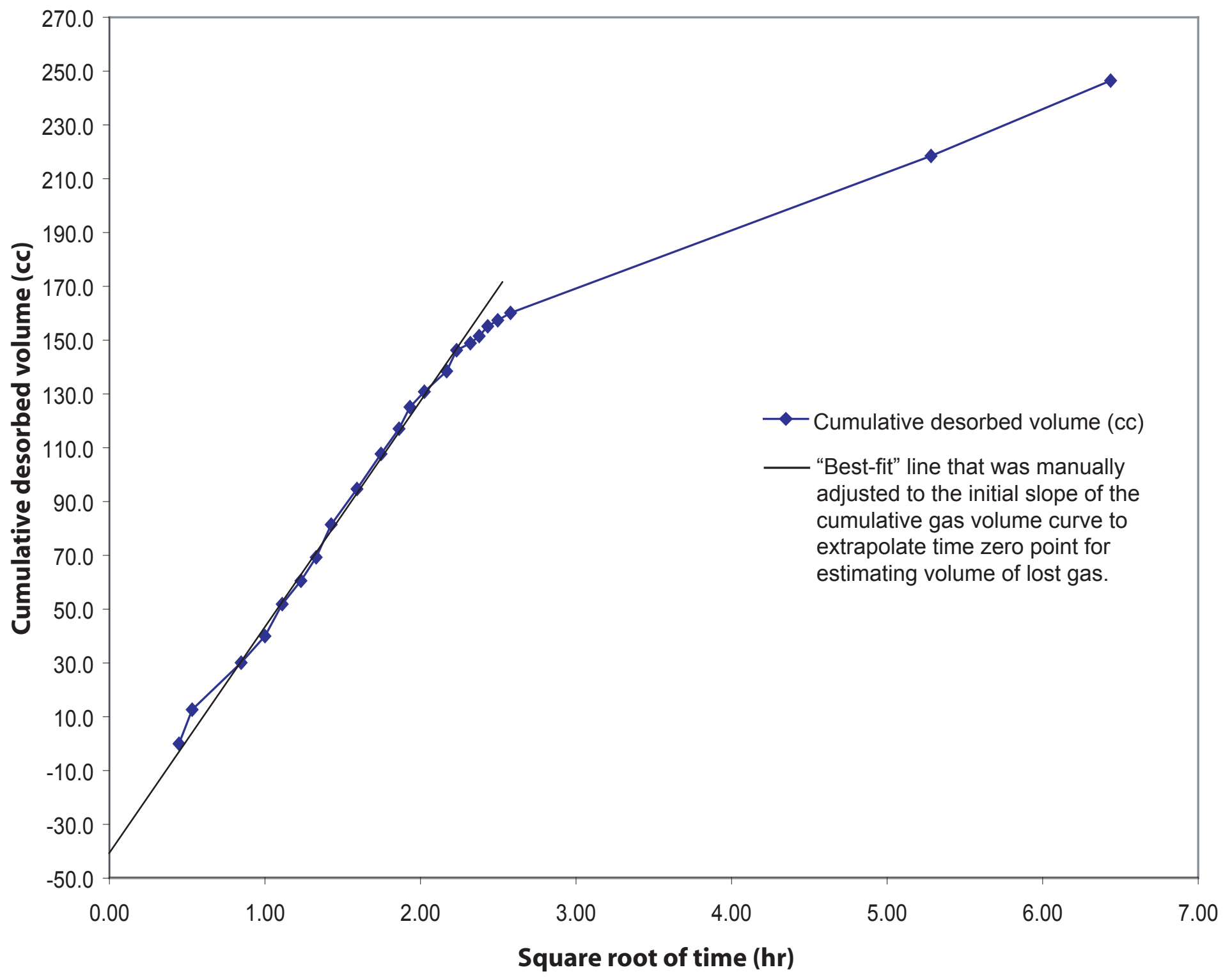

Lost Gas Estimate $=40 \mathrm{cc}$

Raw Total Gas $=\quad 0.26 \mathrm{~g} / \mathrm{cc}$ (8.46 SCF/ton)

DAF Total Gas $=\quad 0.43 \mathrm{~g} / \mathrm{cc}(13.62 \mathrm{SCF} / \mathrm{ton})$

g/cc - grams per cubic centimeter

SCF/Ton - Standard Cubic Feet per ton

Figure 5 


\section{Table 5}

\begin{tabular}{|l|l|}
\hline Project & Wilcox, Panola Co., TX \\
\cline { 2 - 2 }
\end{tabular}

\begin{tabular}{lll|c|c|} 
Well ID: & \multicolumn{1}{c|}{ PA 2} & Can no. & $99-5$ \\
Sample Interval (ft): $\quad$ From: & 360 & To:
\end{tabular}

Sample Interval (ft): $\quad$ From:
Core Date: (enter in box: $\mathrm{mm} / \mathrm{dd} / \mathrm{yr}$ )

Time Zero (hh:mm)

Raw coal mass (air-dry): (grams)

Coal mass (d.a.f.): (grams)

Headspace volume:
Cumulative volume @ STP:

Milliliters/gram raw coal:

Milliliter/gram coal d.a.f.: (excluding lost gas)

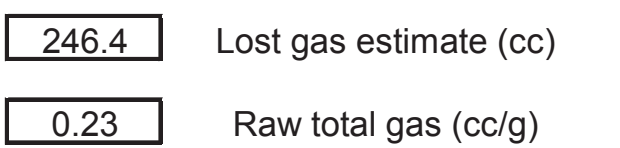

40.0

Raw total gas (SCF/ton)

DAF total gas (SCF/ton)

8.46

Raw total gas $(\mathrm{cc} / \mathrm{g})$

0.26

DAF total gas (cc/g)

0.43

\begin{tabular}{|c|c|c|c|c|c|c|c|c|c|c|c|c|c|c|c|c|c|c|c|}
\hline & \multirow[b]{2}{*}{ Date } & \multirow[b]{2}{*}{$\begin{array}{l}\text { Time } \\
24 \text { hour } \\
\text { Clock } \\
\text { HH:MM }\end{array}$} & \multirow[b]{2}{*}{$\begin{array}{c}\text { Pressure } \\
\text { inches } \\
\mathrm{Hg}\end{array}$} & \multirow[b]{2}{*}{$\begin{array}{c}\text { Canister } \\
\text { Temp. } \\
{ }^{\circ} \mathrm{F}\end{array}$} & \multirow[b]{2}{*}{$\begin{array}{l}\text { Delta } \\
\text { Gas } \\
\text { Volume } \\
\text { (milliliter) }\end{array}$} & \multirow[b]{2}{*}{$\begin{array}{c}\text { Delta } \\
\text { Volume } \\
@ \text { STP } \\
\text { (milliliter) }\end{array}$} & \multirow[b]{2}{*}{$\begin{array}{c}\text { Cumulative } \\
\text { Volume } \\
@ \text { STP } \\
\text { (milliliter) }\end{array}$} & \multirow[b]{2}{*}{$\begin{array}{l}\text { Elapsed } \\
\text { Time } \\
\text { (Time } \\
\text { value) }\end{array}$} & \multirow[b]{2}{*}{$\begin{array}{c}\text { Elapsed } \\
\text { Time }\end{array}$} & \multirow[b]{2}{*}{$\begin{array}{l}\text { Sq. Root } \\
\text { Elapsed } \\
\text { Time } \\
\left(\mathrm{Hrs}^{1 / 2}\right)\end{array}$} & \multirow[b]{2}{*}{$\begin{array}{c}\mathrm{ml} / \mathrm{gram} \\
\text { Raw } \\
\text { Coal } \\
\text { Mass }\end{array}$} & \multirow[b]{2}{*}{$\begin{array}{l}\mathrm{ml} / \mathrm{g} \\
\text { d.a.f } \\
\text { Coal } \\
\text { Mass }\end{array}$} & \multicolumn{2}{|c|}{ Headspace Correction } & \multicolumn{5}{|c|}{ Optional Temperature Conversions } \\
\hline & & & & & & & & & & & & & $\begin{array}{c}\text { Cumulative } \\
\text { Volume } \\
\text { @ STP } \\
\text { (milliliter) }\end{array}$ & $\begin{array}{c}\text { Cumulative } \\
\text { Gas } \\
\text { Content } \\
\text { (SCF) }\end{array}$ & $\begin{array}{c}\text { Ambient } \\
\text { Temp } \\
{ }^{\circ} \mathrm{F}\end{array}$ & $\begin{array}{c}\text { Ambient } \\
\text { temp } \\
\text { in oC }\end{array}$ & $\begin{array}{l}\text { Convert } \\
\text { deg } \mathrm{C} \\
\text { to } \operatorname{deg} \mathrm{F}\end{array}$ & $\begin{array}{c}\text { Canister } \\
\text { temp } \\
\text { in oC }\end{array}$ & $\begin{array}{l}\text { Convert } \\
\text { deg C } \\
\text { to } \operatorname{deg} F\end{array}$ \\
\hline 1 & $6 / 27 / 1999$ & $13: 58$ & 29.68 & 89.8 & 14 & 13.14 & 0.00 & 0.01 & 0.20 & 0.45 & 0.00 & 0.00 & 0.0 & 0.0 & 89.6 & 32.0 & 89.6 & 32.1 & 89.8 \\
\hline 2 & $6 / 27 / 1999$ & $14: 03$ & 29.68 & 88.3 & 10 & 9.41 & 9.41 & 0.01 & 0.28 & 0.53 & 0.01 & 0.01 & 12.7 & 0.4 & 89.2 & 31.8 & 89.2 & 31.3 & 88.3 \\
\hline 3 & $6 / 27 / 1999$ & $14: 29$ & 29.68 & 87.8 & 18 & 16.96 & 26.37 & 0.03 & 0.72 & 0.85 & 0.02 & 0.04 & 30.1 & 1.3 & 88.5 & 31.4 & 88.5 & 31.0 & 87.8 \\
\hline 4 & $6 / 27 / 1999$ & $14: 46$ & 29.65 & 89.2 & 17 & 15.96 & 42.33 & 0.04 & 1.00 & 1.00 & 0.04 & 0.06 & 40.0 & 2.4 & 88.5 & 31.4 & 88.5 & 31.8 & 89.2 \\
\hline 5 & $6 / 27 / 1999$ & $15: 00$ & 29.65 & 89.8 & 15 & 14.07 & 56.40 & 0.05 & 1.23 & 1.11 & 0.05 & 0.08 & 51.9 & 4.0 & 88.7 & 31.5 & 88.7 & 32.1 & 89.8 \\
\hline 6 & $6 / 27 / 1999$ & $15: 17$ & 29.65 & 91.2 & 14 & 13.10 & 69.49 & 0.06 & 1.52 & 1.23 & 0.06 & 0.10 & 60.6 & 5.8 & 88.7 & 31.5 & 88.7 & 32.9 & 91.2 \\
\hline 7 & $6 / 27 / 1999$ & $15: 32$ & 29.62 & 91.4 & 12 & 11.21 & 80.70 & 0.07 & 1.77 & 1.33 & 0.07 & 0.12 & 69.3 & 7.8 & 88.5 & 31.4 & 88.5 & 33.0 & 91.4 \\
\hline 8 & $6 / 27 / 1999$ & $15: 48$ & 29.62 & 90.1 & 10 & 9.36 & 90.06 & 0.08 & 2.03 & 1.43 & 0.08 & 0.13 & 81.4 & 10.2 & 89.1 & 31.7 & 89.1 & 32.3 & 90.1 \\
\hline 9 & $6 / 27 / 1999$ & $16: 18$ & 29.62 & 90.9 & 17 & 15.90 & 105.96 & 0.11 & 2.53 & 1.59 & 0.10 & 0.16 & 94.7 & 13.0 & 88.5 & 31.4 & 88.5 & 32.7 & 90.9 \\
\hline 10 & $6 / 27 / 1999$ & $16: 49$ & 29.62 & 89.6 & 11 & 10.31 & 116.27 & 0.13 & 3.05 & 1.75 & 0.11 & 0.17 & 107.7 & 16.2 & 88.2 & 31.2 & 88.2 & 32.0 & 89.6 \\
\hline 11 & $6 / 27 / 1999$ & $17: 14$ & 29.62 & 89.4 & 10 & 9.37 & 125.64 & 0.14 & 3.47 & 1.86 & 0.12 & 0.19 & 117.1 & 19.7 & 88.2 & 31.2 & 88.2 & 31.9 & 89.4 \\
\hline 12 & $6 / 27 / 1999$ & $17: 30$ & 29.62 & 89.1 & 8 & 7.50 & 133.15 & 0.16 & 3.73 & 1.93 & 0.12 & 0.20 & 125.1 & 23.4 & 88.2 & 31.2 & 88.2 & 31.7 & 89.1 \\
\hline 13 & $6 / 27 / 1999$ & $17: 52$ & 29.59 & 88.7 & 7 & 6.56 & 139.71 & 0.17 & 4.10 & 2.02 & 0.13 & 0.21 & 130.8 & 27.2 & 87.8 & 31.0 & 87.8 & 31.5 & 88.7 \\
\hline 14 & $6 / 27 / 1999$ & $18: 28$ & 29.59 & 88.2 & 7 & 6.57 & 146.28 & 0.20 & 4.70 & 2.17 & 0.13 & 0.22 & 138.5 & 31.3 & 88.0 & 31.1 & 88.0 & 31.2 & 88.2 \\
\hline 15 & $6 / 27 / 1999$ & $18: 45$ & 29.59 & 86.9 & 5 & 4.70 & 150.99 & 0.21 & 4.98 & 2.23 & 0.14 & 0.22 & 146.2 & 35.6 & 88.0 & 31.1 & 88.0 & 30.5 & 86.9 \\
\hline 16 & $6 / 27 / 1999$ & $19: 09$ & 29.59 & 87.3 & 4 & 3.76 & 154.75 & 0.22 & 5.38 & 2.32 & 0.14 & 0.23 & 148.8 & 40.0 & 87.4 & 30.8 & 87.4 & 30.7 & 87.3 \\
\hline 17 & $6 / 27 / 1999$ & $19: 25$ & 29.59 & 87.3 & 3 & 2.82 & 157.57 & 0.24 & 5.65 & 2.38 & 0.15 & 0.23 & 151.5 & 44.5 & 87.3 & 30.7 & 87.3 & 30.7 & 87.3 \\
\hline 18 & $6 / 27 / 1999$ & $19: 41$ & 29.59 & 86.9 & 3 & 2.82 & 160.39 & 0.25 & 5.92 & 2.43 & 0.15 & 0.24 & 155.1 & 49.1 & 87.4 & 30.8 & 87.4 & 30.5 & 86.9 \\
\hline 19 & $6 / 27 / 1999$ & $20: 00$ & 29.59 & 86.7 & 2 & 1.88 & 162.28 & 0.26 & 6.23 & 2.50 & 0.15 & 0.24 & 157.4 & 53.8 & 87.4 & 30.8 & 87.4 & 30.4 & 86.7 \\
\hline 20 & $6 / 27 / 1999$ & $20: 25$ & 29.59 & 86.4 & 2 & 1.88 & 164.16 & 0.28 & 6.65 & 2.58 & 0.15 & 0.24 & 160.1 & 58.5 & 87.6 & 30.9 & 87.6 & 30.2 & 86.4 \\
\hline 21 & $6 / 28 / 1999$ & $17: 40$ & 29.62 & 99.0 & 104 & 95.83 & 259.99 & 1.16 & 27.90 & 5.28 & 0.24 & 0.39 & 218.4 & 64.9 & 105.8 & 41.0 & 105.8 & 37.2 & 99.0 \\
\hline 22 & $6 / 29 / 1999$ & $7: 12$ & 29.56 & 86.0 & -3 & 0.00 & 259.99 & 1.73 & 41.43 & 6.44 & 0.24 & 0.39 & 246.4 & 72.2 & 86.9 & 30.5 & 86.9 & 30.0 & 86.0 \\
\hline
\end{tabular}




\section{Cumulative Gas Desorbed (cc) \\ (USGS-PA-2-CN6)}

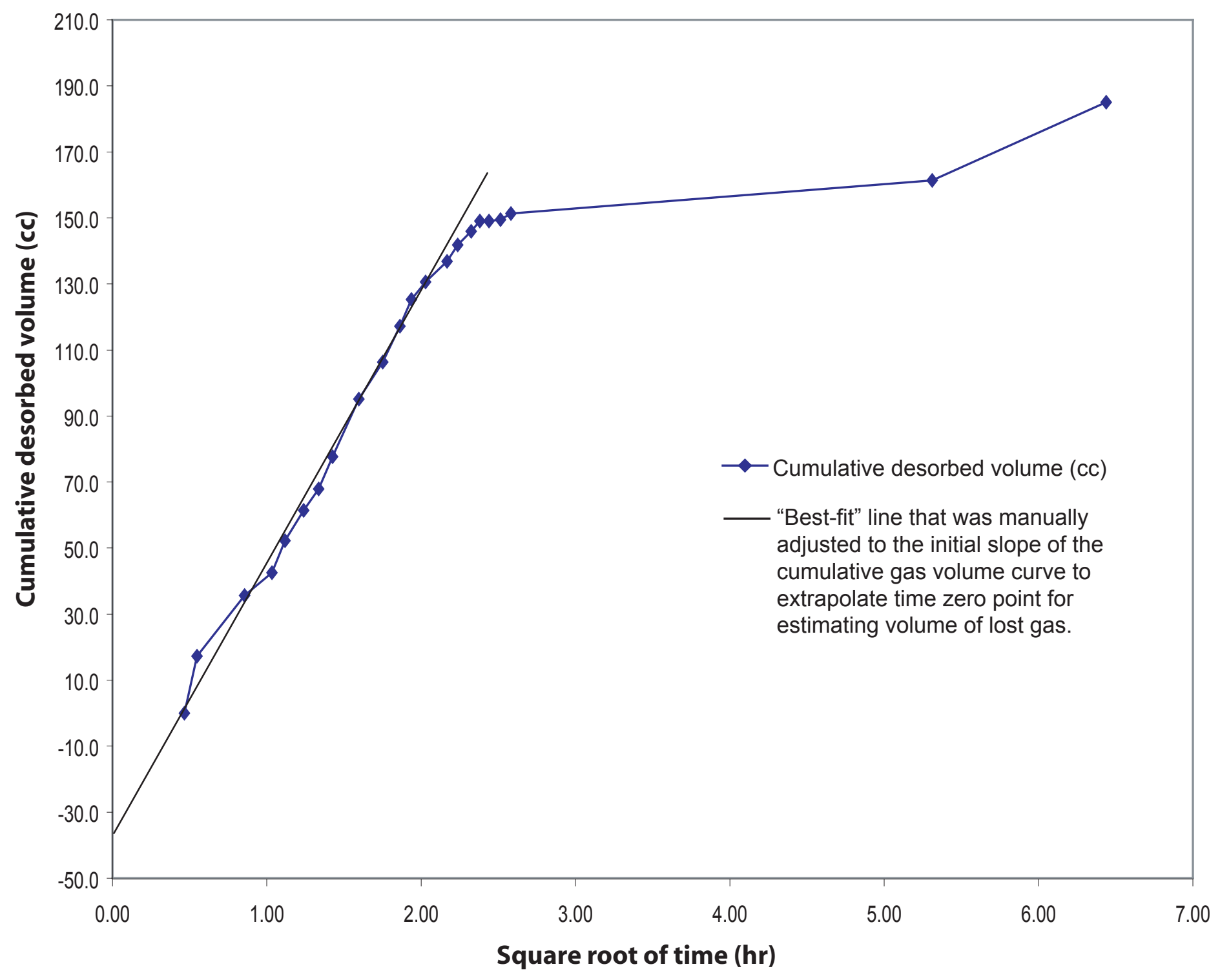

Lost Gas Estimate $=35 \mathrm{cc}$

Raw Total Gas $=\quad 0.20 \mathrm{~g} / \mathrm{cc}(6.46 \mathrm{SCF} / \mathrm{ton})$

DAF Total Gas $=\quad 0.29 \mathrm{~g} / \mathrm{cc}(9.35 \mathrm{SCF} / \mathrm{ton})$

g/cc - grams per cubic centimeter

SCF/Ton - Standard Cubic Feet per ton

Figure 6 


\section{Table 6}

Project Wilcox, Panola Co., TX

\begin{tabular}{l|cc|c|} 
Well ID: & \multicolumn{1}{c}{ Can no. } & $99-6$ & \\
Sample Interval (ft): $\quad$ From: & 360 & To: & 361
\end{tabular} Core Date: (enter in box: $\mathrm{mm} / \mathrm{dd} / \mathrm{yr}$ )

Time Zero (hh:mm)

Raw coal mass (air-dry): (grams)

Coal mass (d.a.f.): (grams)

Headspace volume:

\begin{tabular}{|l|}
\hline $6 / 27 / 1999$ \\
\hline $13: 46$ \\
\hline
\end{tabular}

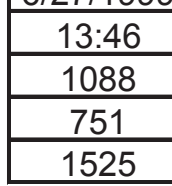

Cumulative volume @ STP:

Milliliters/gram raw coal:

Milliliter/gram coal d.a.f.: (excluding lost gas)

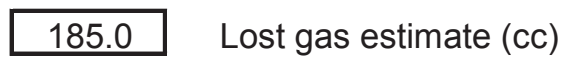

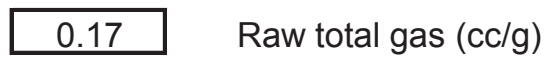

0.25

DAF total gas (cc/g)
Raw total gas (SCF/ton)

DAF total gas (SCF/ton)

\begin{tabular}{|c|c|c|c|c|c|c|c|c|c|c|c|c|c|c|c|c|c|c|c|}
\hline & \multirow[b]{2}{*}{ Date } & \multirow[b]{2}{*}{$\begin{array}{l}\text { Time } \\
24 \text { hour } \\
\text { Clock } \\
\text { HH:MM }\end{array}$} & \multirow[b]{2}{*}{$\begin{array}{c}\text { Pressure } \\
\text { inches } \\
\mathrm{Hg}\end{array}$} & \multirow[b]{2}{*}{$\begin{array}{c}\text { Canister } \\
\text { Temp. } \\
{ }^{\circ} \mathrm{F} \\
\end{array}$} & \multirow[b]{2}{*}{$\begin{array}{l}\text { Delta } \\
\text { Gas } \\
\text { Volume } \\
\text { (milliliter) } \\
\end{array}$} & \multirow[b]{2}{*}{$\begin{array}{l}\text { Delta } \\
\text { Volume } \\
@ \text { STP } \\
\text { (milliliter) }\end{array}$} & \multirow[b]{2}{*}{$\begin{array}{c}\text { Cumulative } \\
\text { Volume } \\
@ \text { STP } \\
\text { (milliliter) }\end{array}$} & \multirow[b]{2}{*}{$\begin{array}{c}\text { Elapsed } \\
\text { Time } \\
\text { (Time } \\
\text { value) }\end{array}$} & \multirow[b]{2}{*}{$\begin{array}{c}\text { Elapsed } \\
\text { Time }\end{array}$} & \multirow[b]{2}{*}{$\begin{array}{c}\text { Sq. Root } \\
\text { Elapsed } \\
\text { Time } \\
\left(\mathrm{Hrs}^{1 / 2}\right) \\
\end{array}$} & \multirow[b]{2}{*}{$\begin{array}{c}\mathrm{ml} / \mathrm{gram} \\
\text { Raw } \\
\text { Coal } \\
\text { Mass }\end{array}$} & \multirow[b]{2}{*}{$\begin{array}{l}\mathrm{ml} / \mathrm{g} \\
\text { d.a.f } \\
\text { Coal } \\
\text { Mass } \\
\end{array}$} & \multicolumn{2}{|c|}{ Headspace Correction } & \multicolumn{5}{|c|}{ Optional Temperature Conversions } \\
\hline & & & & & & & & & & & & & $\begin{array}{c}\text { Cumulative } \\
\text { Volume } \\
\text { @ STP } \\
\text { (milliliter) }\end{array}$ & $\begin{array}{c}\text { Cumulative } \\
\text { Gas } \\
\text { Content } \\
\text { (SCF) }\end{array}$ & $\begin{array}{c}\text { Ambient } \\
\text { Temp } \\
{ }^{\circ} \mathrm{F}\end{array}$ & $\begin{array}{c}\text { Ambient } \\
\text { temp } \\
\text { in oC }\end{array}$ & $\begin{array}{l}\text { Convert } \\
\operatorname{deg} \mathrm{C} \\
\text { to } \operatorname{deg} \mathrm{F}\end{array}$ & $\begin{array}{c}\text { Canister } \\
\text { temp } \\
\text { in oC }\end{array}$ & $\begin{array}{c}\text { Convert } \\
\text { deg C } \\
\text { to } \operatorname{deg} F\end{array}$ \\
\hline 1 & $6 / 27 / 1999$ & $13: 59$ & 29.68 & 90.9 & 19 & 17.80 & $\begin{array}{l}0.00 \\
\end{array}$ & 0.01 & 0.22 & 0.47 & 0.00 & 0.00 & 0.0 & 0.0 & 89.6 & 32.0 & 89.6 & 32.7 & 90.9 \\
\hline 2 & $6 / 27 / 1999$ & 14:04 & 29.68 & 88.7 & 13 & 12.23 & 12.23 & 0.01 & 0.30 & 0.55 & 0.01 & 0.02 & 16.9 & 0.5 & 89.2 & 31.8 & 89.2 & 31.5 & 88.7 \\
\hline 3 & $6 / 27 / 1999$ & 14:30 & 29.68 & 87.8 & 18 & 16.96 & 29.19 & 0.03 & 0.73 & 0.86 & 0.03 & 0.04 & 35.1 & 1.5 & 88.5 & 31.4 & 88.5 & 31.0 & 87.8 \\
\hline 4 & $6 / 27 / 1999$ & $14: 50$ & 29.65 & 90.7 & 18 & 16.85 & 46.04 & 0.04 & 1.07 & 1.03 & 0.04 & 0.06 & 42.6 & 2.8 & 88.5 & 31.4 & 88.5 & 32.6 & 90.7 \\
\hline 5 & $6 / 27 / 1999$ & 15:01 & 29.65 & 91.8 & 14 & 13.08 & 59.12 & 0.05 & 1.25 & 1.12 & 0.05 & 0.08 & 52.4 & 4.3 & 88.7 & 31.5 & 88.7 & 33.2 & 91.8 \\
\hline 6 & $6 / 27 / 1999$ & $15: 18$ & 29.65 & 92.7 & 13 & 12.13 & 71.25 & 0.06 & 1.53 & 1.24 & 0.07 & 0.09 & 61.8 & 6.1 & 88.7 & 31.5 & 88.7 & 33.7 & 92.7 \\
\hline 7 & $6 / 27 / 1999$ & $15: 33$ & 29.62 & 93.4 & 11 & 10.24 & 81.49 & 0.07 & 1.78 & 1.34 & 0.07 & 0.11 & 68.4 & 8.2 & 88.5 & 31.4 & 88.5 & 34.1 & 93.4 \\
\hline 8 & $6 / 27 / 1999$ & $15: 48$ & 29.62 & 93.0 & 10 & 9.31 & 90.80 & 0.08 & 2.03 & 1.43 & 0.08 & 0.12 & 78.2 & 10.5 & 89.1 & 31.7 & 89.1 & 33.9 & 93.0 \\
\hline 9 & $6 / 27 / 1999$ & $16: 19$ & 29.62 & 91.8 & 16 & 14.94 & 105.74 & 0.11 & 2.55 & 1.60 & 0.10 & 0.14 & 95.5 & 13.3 & 88.5 & 31.4 & 88.5 & 33.2 & 91.8 \\
\hline 10 & $6 / 27 / 1999$ & $16: 50$ & 29.62 & 90.9 & 10 & 9.35 & 115.09 & 0.13 & 3.07 & 1.75 & 0.11 & 0.15 & 106.6 & 16.4 & 88.2 & 31.2 & 88.2 & 32.7 & 90.9 \\
\hline 11 & $6 / 27 / 1999$ & $17: 14$ & 29.62 & 89.8 & 9 & 8.43 & 123.52 & 0.14 & 3.47 & 1.86 & 0.11 & 0.16 & 117.2 & 19.9 & 88.2 & 31.2 & 88.2 & 32.1 & 89.8 \\
\hline 12 & $6 / 27 / 1999$ & $17: 31$ & 29.62 & 89.1 & 7 & 6.57 & 130.09 & 0.16 & 3.75 & 1.94 & 0.12 & 0.17 & 125.2 & 23.6 & 88.2 & 31.2 & 88.2 & 31.7 & 89.1 \\
\hline 13 & $6 / 27 / 1999$ & $17: 53$ & 29.59 & 88.5 & 6 & 5.63 & 135.72 & 0.17 & 4.12 & 2.03 & 0.12 & 0.18 & 130.5 & 27.4 & 87.8 & 31.0 & 87.8 & 31.4 & 88.5 \\
\hline 14 & $6 / 27 / 1999$ & $18: 28$ & 29.59 & 88.2 & 6 & 5.63 & 141.35 & 0.20 & 4.70 & 2.17 & 0.13 & 0.19 & 136.7 & 31.4 & 88.0 & 31.1 & 88.0 & 31.2 & 88.2 \\
\hline 15 & $6 / 27 / 1999$ & $18: 46$ & 29.59 & 87.6 & 4 & 3.76 & 145.11 & 0.21 & 5.00 & 2.24 & 0.13 & 0.19 & 141.6 & 35.6 & 88.0 & 31.1 & 88.0 & 30.9 & 87.6 \\
\hline 16 & $6 / 27 / 1999$ & 19:10 & 29.59 & 87.1 & 3 & 2.82 & 147.93 & 0.23 & 5.40 & 2.32 & 0.14 & 0.20 & 145.6 & 39.9 & 87.4 & 30.8 & 87.4 & 30.6 & 87.1 \\
\hline 17 & $6 / 27 / 1999$ & $19: 26$ & 29.59 & 86.9 & 3 & 2.82 & 150.75 & 0.24 & 5.67 & 2.38 & 0.14 & 0.20 & 148.7 & 44.3 & 87.3 & 30.7 & 87.3 & 30.5 & 86.9 \\
\hline 18 & $6 / 27 / 1999$ & $19: 43$ & 29.59 & 86.9 & 0 & 0.00 & 150.75 & 0.25 & 5.95 & 2.44 & 0.14 & 0.20 & 148.7 & 48.6 & 87.4 & 30.8 & 87.4 & 30.5 & 86.9 \\
\hline 19 & $6 / 27 / 1999$ & 20:05 & 29.59 & 87.1 & 1 & 0.94 & 151.69 & 0.26 & 6.32 & 2.51 & 0.14 & 0.20 & 149.1 & 53.0 & 87.4 & 30.8 & 87.4 & 30.6 & 87.1 \\
\hline 20 & $6 / 27 / 1999$ & $20: 26$ & 29.62 & 87.3 & 1 & 0.94 & 152.63 & 0.28 & 6.67 & 2.58 & 0.14 & 0.20 & 151.0 & 57.5 & 87.6 & 30.9 & 87.6 & 30.7 & 87.3 \\
\hline 21 & $6 / 28 / 1999$ & $17: 58$ & 29.53 & 93.9 & 37 & 34.30 & 186.93 & 1.18 & 28.20 & 5.31 & 0.17 & 0.25 & 162.3 & 62.2 & 105.8 & 41.0 & 105.8 & 34.4 & 93.9 \\
\hline 22 & $6 / 29 / 1999$ & $7: 13$ & 29.59 & 85.6 & -1 & 0.00 & 186.93 & 1.73 & 41.45 & 6.44 & 0.17 & 0.25 & 184.5 & 67.7 & 86.9 & 30.5 & 86.9 & 29.8 & 85.6 \\
\hline
\end{tabular}




\section{Cumulative Gas Desorbed (cc) \\ (USGS-PA-2-CN7)}

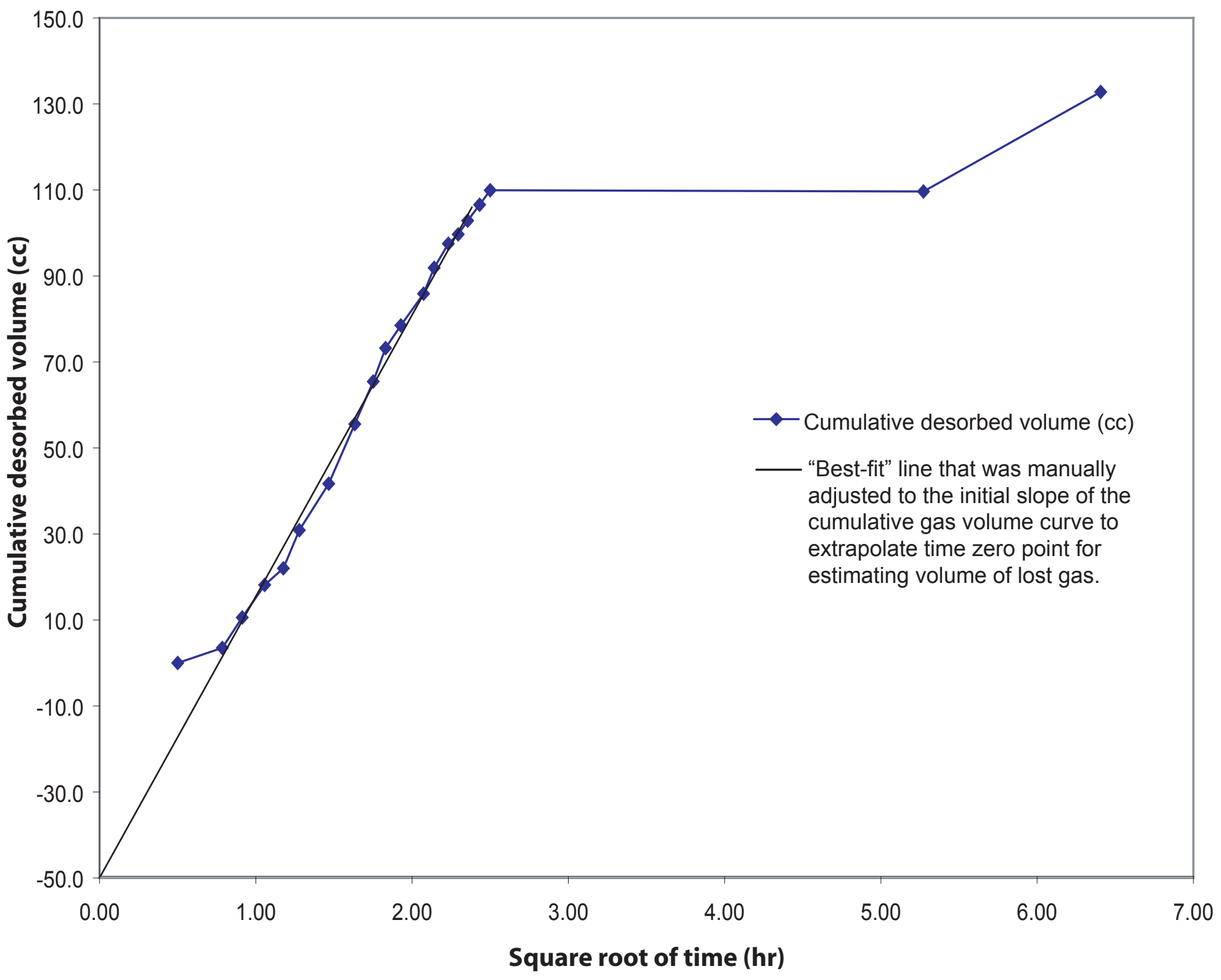

Lost Gas Estimate $=50 \mathrm{cc}$

Raw Total Gas $=\quad 0.19 \mathrm{~g} / \mathrm{cc}(6.02 \mathrm{SCF} /$ ton $)$

DAF Total Gas $=\quad 0.30 \mathrm{~g} / \mathrm{cc}(9.73 \mathrm{SCF} / \mathrm{ton})$

g/cc - grams per cubic centimeter

SCF/Ton - Standard Cubic Feet per ton

Figure 7 


\section{Table 7}

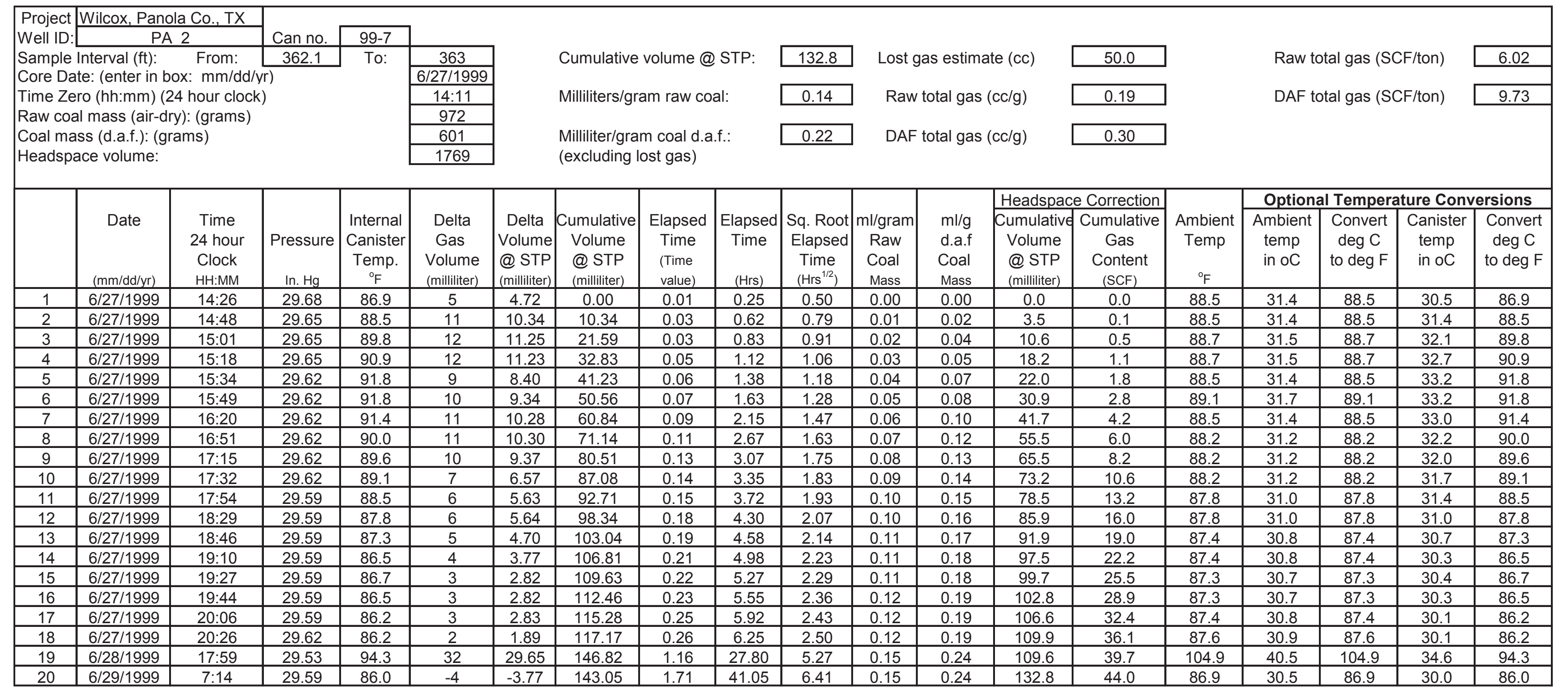




\section{Cumulative Gas Desorbed (cc) \\ (USGS-PA-2-CN8)}

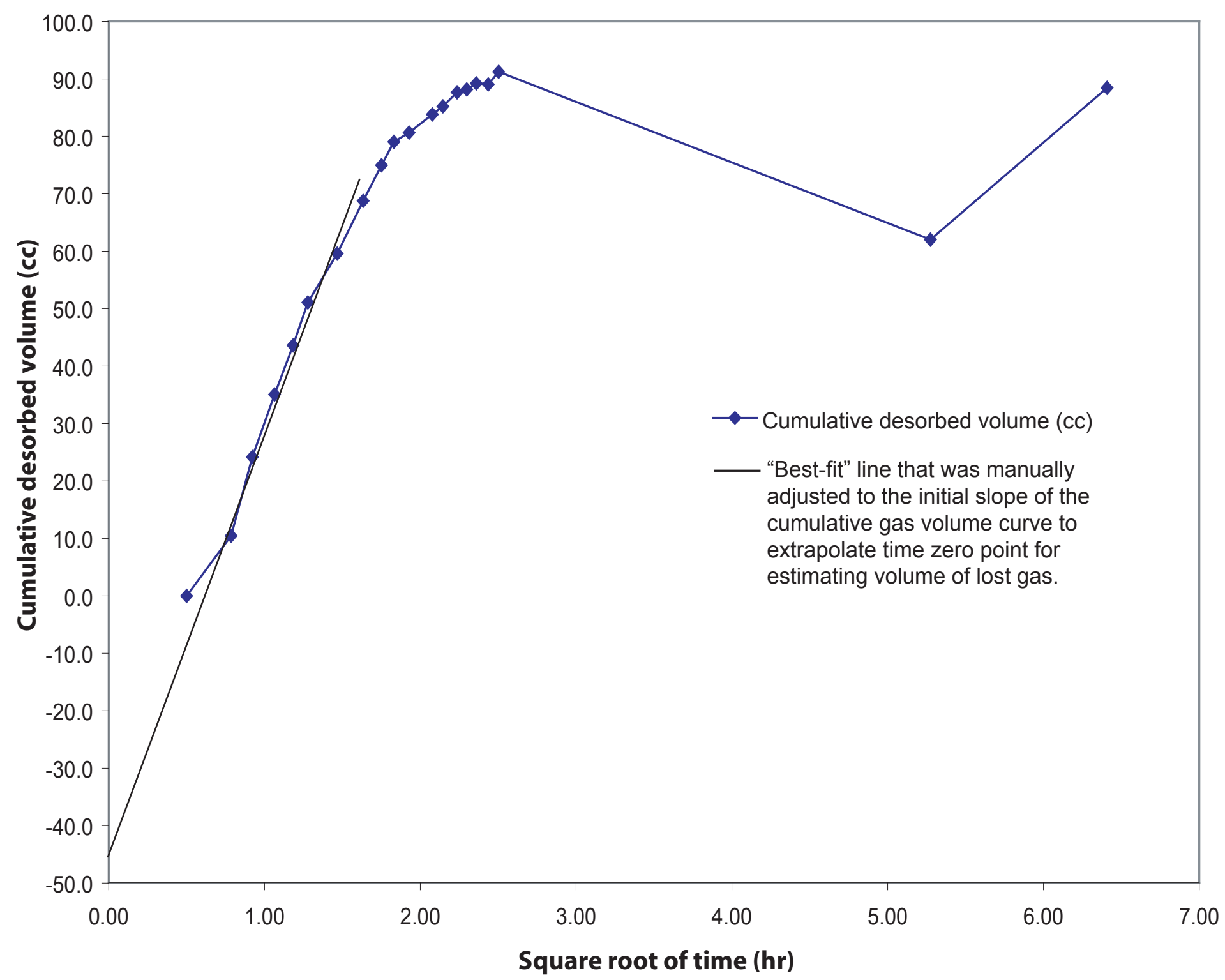

Lost Gas Estimate $=45 \mathrm{cc}$

Raw Total Gas $=\quad 0.12 \mathrm{~g} / \mathrm{cc}$ (3.77 SCF/ton)

DAF Total Gas $=\quad 0.30 \mathrm{~g} / \mathrm{cc}(9.75 \mathrm{SCF} / \mathrm{ton})$

g/cc - grams per cubic centimeter

SCF/Ton - Standard Cubic Feet per ton

Figure 8 


\section{Table 8}

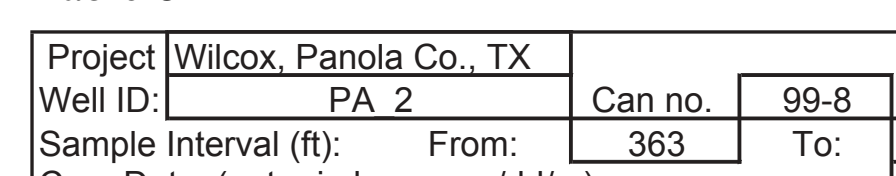
Core Date: (enter in box: $\mathrm{mm} / \mathrm{dd} / \mathrm{yr}$ ) Time Zero (hh:mm) (24 hour clock) Raw coal mass (air-dry): (grams)

Coal mass (d.a.f.): (grams)

Headspace volume:

\begin{tabular}{|c|c|c|c|c|c|c|c|c|c|c|c|c|c|c|c|c|c|c|c|}
\hline & \multirow[b]{2}{*}{ Date } & \multirow[b]{2}{*}{$\begin{array}{c}\text { Time } \\
24 \text { hour } \\
\text { Clock } \\
\text { HH:MM }\end{array}$} & \multirow[b]{2}{*}{$\begin{array}{c}\text { Pressure } \\
\text { inches } \\
\mathrm{Hg}\end{array}$} & \multirow[b]{2}{*}{$\begin{array}{c}\text { Internal } \\
\text { Canister } \\
\text { Temp. } \\
{ }^{\circ} \mathrm{F}\end{array}$} & \multirow[b]{2}{*}{$\begin{array}{l}\text { Delta } \\
\text { Gas } \\
\text { Volume } \\
\text { (milliliter) }\end{array}$} & \multirow[b]{2}{*}{\begin{tabular}{|c} 
Delta \\
Volume \\
$@$ STP \\
(milliliter) \\
\end{tabular}} & \multirow[b]{2}{*}{$\begin{array}{c}\text { Cumulative } \\
\text { Volume } \\
@ \text { STP } \\
\text { (milliliter) }\end{array}$} & \multirow[b]{2}{*}{$\begin{array}{l}\text { Elapsed } \\
\text { Time } \\
\text { (Time } \\
\text { value) }\end{array}$} & \multirow[b]{2}{*}{$\begin{array}{c}\text { Elapsed } \\
\text { Time } \\
\\
(\mathrm{Hrs})\end{array}$} & \multirow[b]{2}{*}{$\begin{array}{c}\text { Sq. Root } \\
\text { Elapsed } \\
\text { Time } \\
\left(\mathrm{Hrs}^{1 / 2}\right)\end{array}$} & \multirow[b]{2}{*}{$\begin{array}{c}\mathrm{ml} / \mathrm{gram} \\
\text { Raw } \\
\text { Coal } \\
\text { Mass }\end{array}$} & \multirow[b]{2}{*}{$\begin{array}{l}\mathrm{ml} / \mathrm{g} \\
\text { d.a.f } \\
\text { Coal } \\
\text { Mass }\end{array}$} & \multirow{2}{*}{\multicolumn{2}{|c|}{\begin{tabular}{|c|c|}
\multicolumn{2}{|c|}{ Headspace Correction } \\
Cumulative & Cumulative \\
Volume & Gas \\
@ STP & Content \\
(milliliter) & (SCF) \\
\end{tabular}}} & \multirow[b]{2}{*}{$\begin{array}{c}\text { Ambient } \\
\text { Temp } \\
{ }^{\circ} \mathrm{F} \\
\end{array}$} & \multicolumn{4}{|c|}{ Optional Temperature Conversions } \\
\hline & & & & & & & & & & & & & & & & $\begin{array}{c}\text { Ambient } \\
\text { temp } \\
\text { in oC }\end{array}$ & $\begin{array}{c}\text { Convert } \\
\text { deg C } \\
\text { to deg F }\end{array}$ & $\begin{array}{c}\text { Canister } \\
\text { temp } \\
\text { in oC }\end{array}$ & $\begin{array}{c}\text { Convert } \\
\text { deg C } \\
\text { to deg } \mathrm{F}\end{array}$ \\
\hline 1 & $6 / 27 / 1999$ & $14: 26$ & 29.68 & \begin{tabular}{|l|}
86.5 \\
\end{tabular} & 21 & 19.83 & $\begin{array}{l}0.00 \\
\end{array}$ & 0.01 & 0.25 & \begin{tabular}{|l|}
0.50 \\
\end{tabular} & $\begin{array}{ll}0.00 \\
\end{array}$ & 0.00 & 0.0 & 0.0 & 88.5 & 31.4 & 88.5 & 30.3 & 86.5 \\
\hline 2 & $6 / 27 / 1999$ & $14: 48$ & 29.65 & 88.5 & 20 & 18.80 & 18.80 & 0.03 & 0.62 & 0.79 & 0.02 & 0.04 & 10.5 & 0.3 & 88.7 & 31.5 & 88.7 & 31.4 & 88.5 \\
\hline 3 & $6 / 27 / 1999$ & $15: 02$ & 29.65 & 88.7 & 16 & 15.03 & 33.83 & 0.04 & 0.85 & 0.92 & 0.03 & 0.08 & 24.2 & 1.0 & 88.7 & 31.5 & 88.7 & 31.5 & 88.7 \\
\hline 4 & $6 / 27 / 1999$ & $15: 19$ & 29.65 & 89.2 & 14 & 13.14 & 46.98 & 0.05 & 1.13 & 1.06 & 0.04 & 0.11 & 35.1 & 1.9 & 88.7 & 31.5 & 88.7 & 31.8 & 89.2 \\
\hline 5 & $6 / 27 / 1999$ & $15: 35$ & 29.62 & 89.4 & 12 & 11.25 & 58.23 & 0.06 & 1.40 & 1.18 & 0.05 & 0.13 & 43.6 & 3.1 & 88.5 & 31.4 & 88.5 & 31.9 & 89.4 \\
\hline 6 & $6 / 27 / 1999$ & $15: 49$ & 29.62 & 89.6 & 9 & 8.43 & 66.66 & 0.07 & 1.63 & 1.28 & 0.06 & 0.15 & 51.1 & 4.6 & 89.1 & 31.7 & 89.1 & 32.0 & 89.6 \\
\hline 7 & $6 / 27 / 1999$ & $16: 20$ & 29.62 & 89.4 & 9 & 8.44 & 75.10 & 0.09 & 2.15 & 1.47 & 0.07 & 0.17 & 59.6 & 6.2 & 88.5 & 31.4 & 88.5 & 31.9 & 89.4 \\
\hline 8 & $6 / 27 / 1999$ & $16: 51$ & 29.62 & 88.7 & 8 & 7.51 & 82.61 & 0.11 & 2.67 & 1.63 & 0.07 & 0.18 & 68.8 & 8.1 & 88.2 & 31.2 & 88.2 & 31.5 & 88.7 \\
\hline 9 & $6 / 27 / 1999$ & $17: 15$ & 29.62 & 88.7 & 7 & 6.57 & 89.18 & 0.13 & 3.07 & 1.75 & 0.08 & 0.20 & 75.0 & 10.2 & 88.2 & 31.2 & 88.2 & 31.5 & 88.7 \\
\hline 10 & $6 / 27 / 1999$ & $17: 32$ & 29.62 & 88.5 & 4 & 3.76 & 92.94 & 0.14 & 3.35 & 1.83 & 0.08 & 0.21 & 79.0 & 12.4 & 88.2 & 31.2 & 88.2 & 31.4 & 88.5 \\
\hline 11 & $6 / 27 / 1999$ & $17: 54$ & 29.59 & 88.3 & 3 & 2.82 & 95.75 & 0.15 & 3.72 & 1.93 & 0.08 & 0.21 & 80.6 & 14.6 & 87.8 & 31.0 & 87.8 & 31.3 & 88.3 \\
\hline 12 & $6 / 27 / 1999$ & $18: 30$ & 29.59 & 88.2 & 3 & 2.82 & 98.57 & 0.18 & 4.32 & 2.08 & 0.09 & 0.22 & 83.8 & 17.0 & 87.8 & 31.0 & 87.8 & 31.2 & 88.2 \\
\hline 13 & $6 / 27 / 1999$ & $18: 47$ & 29.59 & 88.0 & 1 & 0.94 & 99.51 & 0.19 & 4.60 & 2.14 & 0.09 & 0.22 & 85.2 & 19.3 & 87.4 & 30.8 & 87.4 & 31.1 & 88.0 \\
\hline 14 & $6 / 27 / 1999$ & 19:11 & 29.59 & 87.4 & 1 & 0.94 & 100.45 & 0.21 & 5.00 & 2.24 & 0.09 & 0.22 & 87.7 & 21.7 & 87.4 & 30.8 & 87.4 & 30.8 & 87.4 \\
\hline 15 & $6 / 27 / 1999$ & $19: 28$ & 29.59 & 87.3 & 0 & 0.00 & 100.45 & 0.22 & 5.28 & 2.30 & 0.09 & 0.22 & 88.2 & 24.2 & 87.3 & 30.7 & 87.3 & 30.7 & 87.3 \\
\hline 16 & $6 / 27 / 1999$ & $19: 45$ & 29.59 & 86.9 & 0 & 0.00 & 100.45 & 0.23 & 5.57 & 2.36 & 0.09 & 0.22 & 89.2 & 26.7 & 87.3 & 30.7 & 87.3 & 30.5 & 86.9 \\
\hline 17 & $6 / 27 / 1999$ & $20: 07$ & 29.59 & 86.9 & -0.2 & -0.19 & 100.26 & 0.25 & 5.93 & 2.44 & 0.09 & 0.22 & 89.0 & 29.1 & 87.3 & 30.7 & 87.3 & 30.5 & 86.9 \\
\hline 18 & $6 / 27 / 1999$ & $20: 27$ & 29.62 & 86.5 & -0.5 & -0.47 & 99.79 & 0.26 & 6.27 & 2.50 & 0.09 & 0.22 & 91.2 & 31.7 & 87.3 & 30.7 & 87.3 & 30.3 & 86.5 \\
\hline 19 & $6 / 28 / 1999$ & $18: 00$ & 29.53 & 96.1 & 3 & 2.77 & 102.56 & 1.16 & 27.82 & 5.27 & 0.09 & 0.23 & 62.0 & 33.4 & 104.7 & 40.4 & 104.7 & 35.6 & 96.1 \\
\hline 20 & $6 / 29 / 1999$ & $7: 15$ & 29.59 & 86.0 & -6 & -5.65 & 96.90 & 1.71 & 41.07 & 6.41 & 0.08 & 0.22 & 88.4 & 35.8 & 86.9 & 30.5 & 86.9 & 30.0 & 86.0 \\
\hline
\end{tabular}

Cumulative volume @ STP:

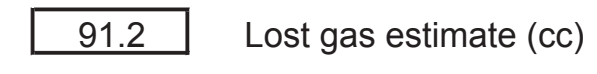

45.0

Raw total gas (SCF/ton)

3.77

\begin{tabular}{|c|}
\hline $6 / 27 / 1999$ \\
\hline $14: 11$ \\
\hline 1155 \\
\hline
\end{tabular}

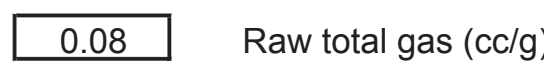

0.08

DAF total gas (SCF/ton)

9.75 $\begin{array}{lll}\text { Milliliter/gram coal d.a.f.: } & 0.20 \quad \text { DAF total gas (cc/g) } & \end{array}$ 


\section{Cumulative Gas Desorbed (cc) \\ (USGS-PA-2-CN9)}

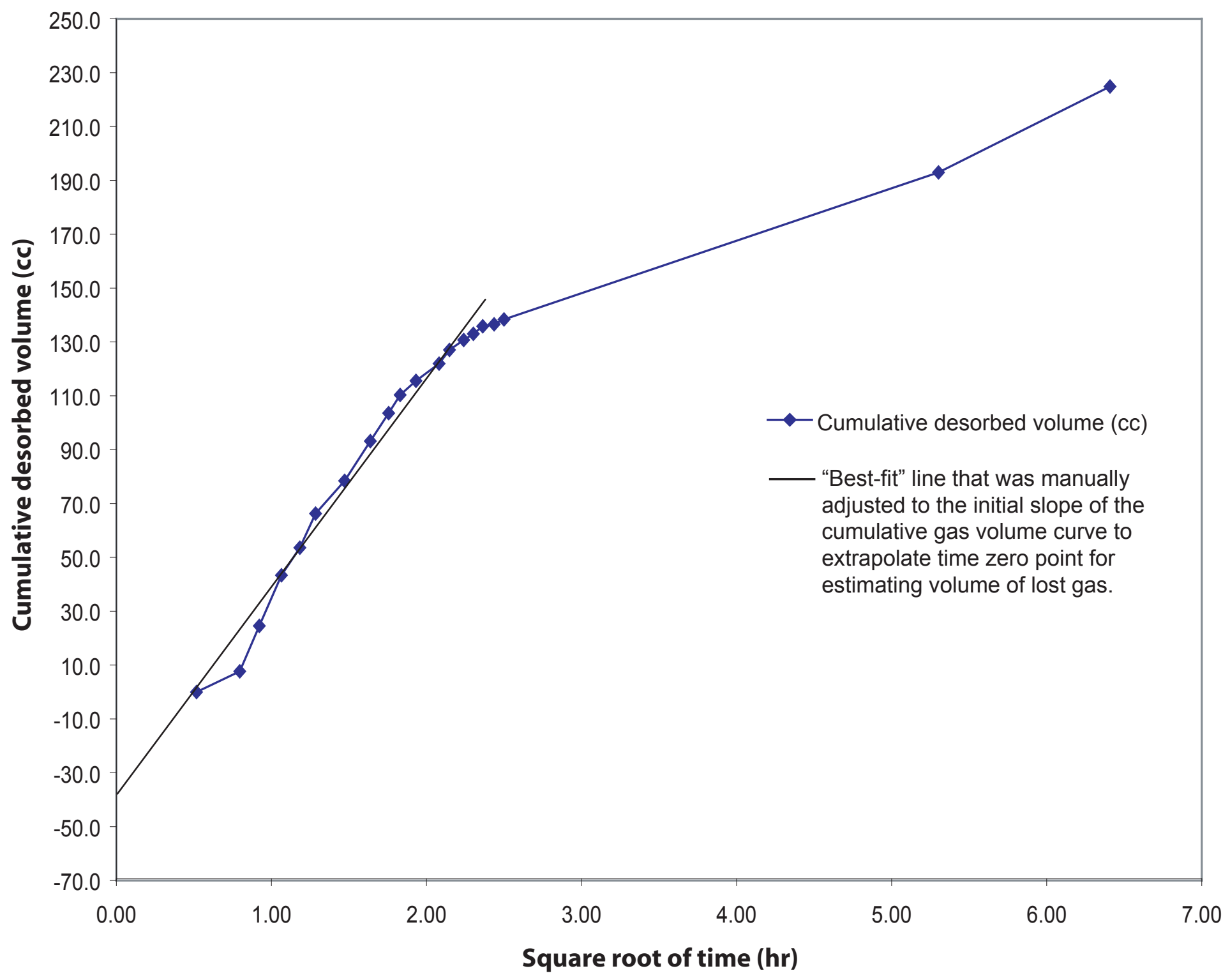

Lost Gas Estimate $=36 \mathrm{cc}$

Raw Total Gas $=\quad 0.27 \mathrm{~g} / \mathrm{cc}(8.54 \mathrm{SCF} /$ ton $)$

DAF Total Gas $=\quad 0.53 \mathrm{~g} / \mathrm{cc}(16.82 \mathrm{SCF} /$ ton $)$

g/cc - grams per cubic centimeter

SCF/Ton - Standard Cubic Feet per ton

\section{Figure 9}




\section{Table 9}

\begin{tabular}{|l|l|}
\hline Project & Wilcox, Panola Co., TX \\
\hline
\end{tabular}

\begin{tabular}{lll|c|c} 
Well ID: & \multicolumn{1}{c|}{ PA 2} & Can no. & $99-9$ \\
\hline Sample Interval (ft): & From: & 364 & To:
\end{tabular} Core Date: (enter in box: $\mathrm{mm} / \mathrm{dd} / \mathrm{yr}$ ) Time Zero (hh:mm) (24 hour clock) Raw coal mass (air-dry): (grams) Coal mass (d.a.f.): (grams) Headspace volume:
Cumulative volume @ STP:

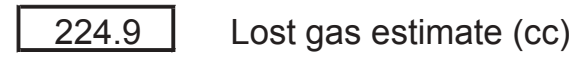

Milliliters/gram raw coal:

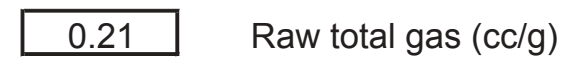

36.0

0.21

0.41 DAF total gas (cc/g)

Milliliter/gram coal d.af:
Raw total gas (SCF/ton)

DAF total gas (SCF/ton)

8.54 (excluding lost gas)

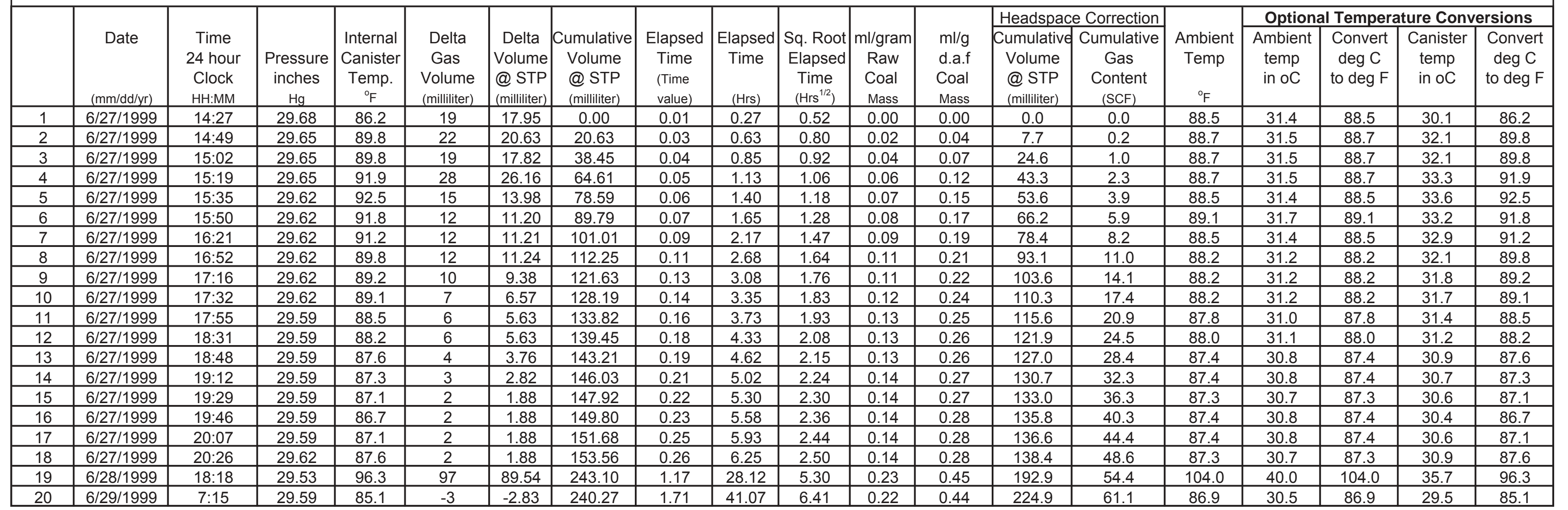




\section{Cumulative Gas Desorbed (cc) \\ (USGS-PA-2-CN11)}

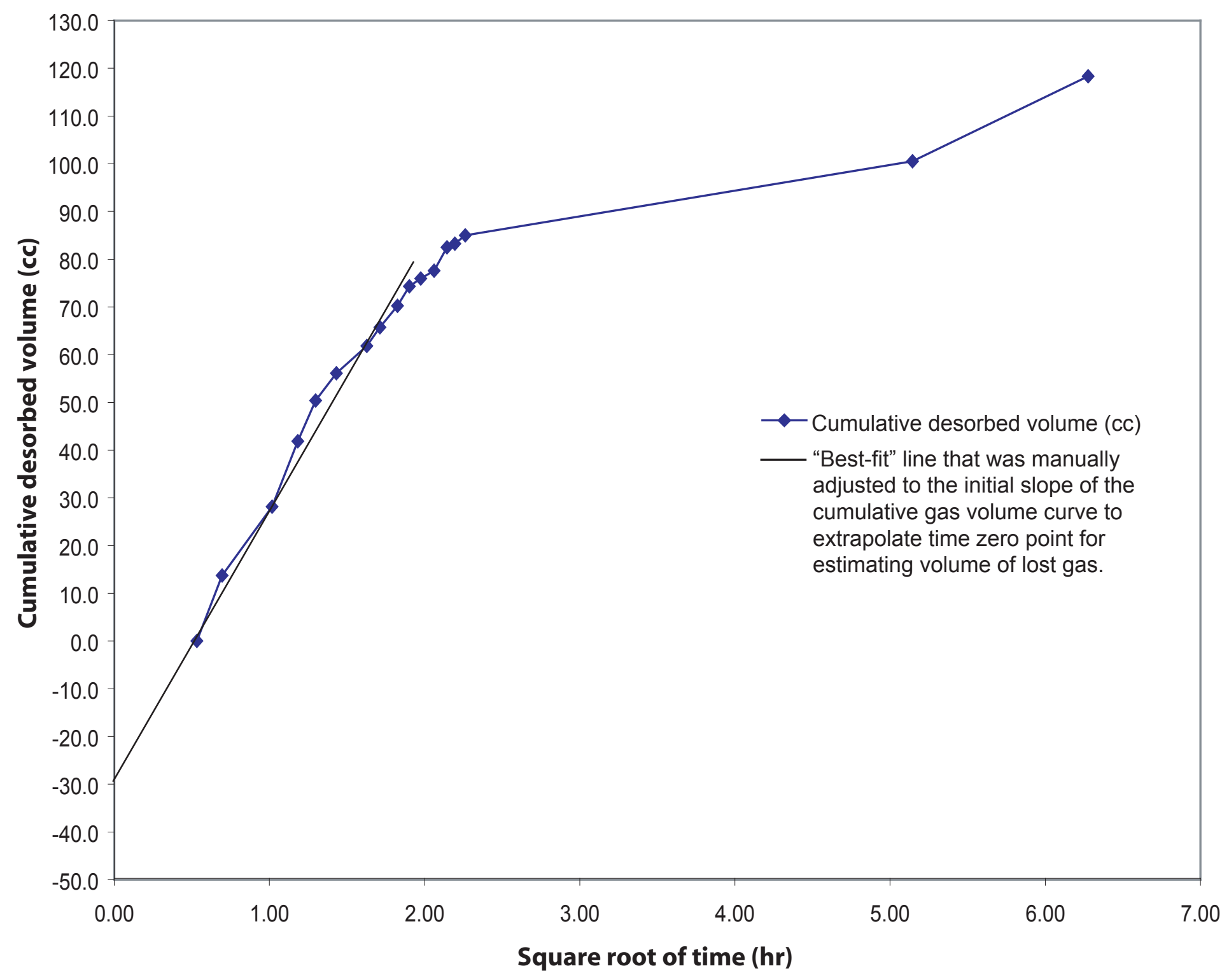

Lost Gas Estimate $=30 \mathrm{cc}$

Raw Total Gas $=\quad 0.16 \mathrm{~g} / \mathrm{cc}(4.96 \mathrm{SCF} / \mathrm{ton})$

DAF Total Gas $=\quad 0.25 \mathrm{~g} / \mathrm{cc}(8.02 \mathrm{SCF} / \mathrm{ton})$

g/cc - grams per cubic centimeter

SCF/Ton - Standard Cubic Feet per ton

Figure 10 


\section{Table 10}

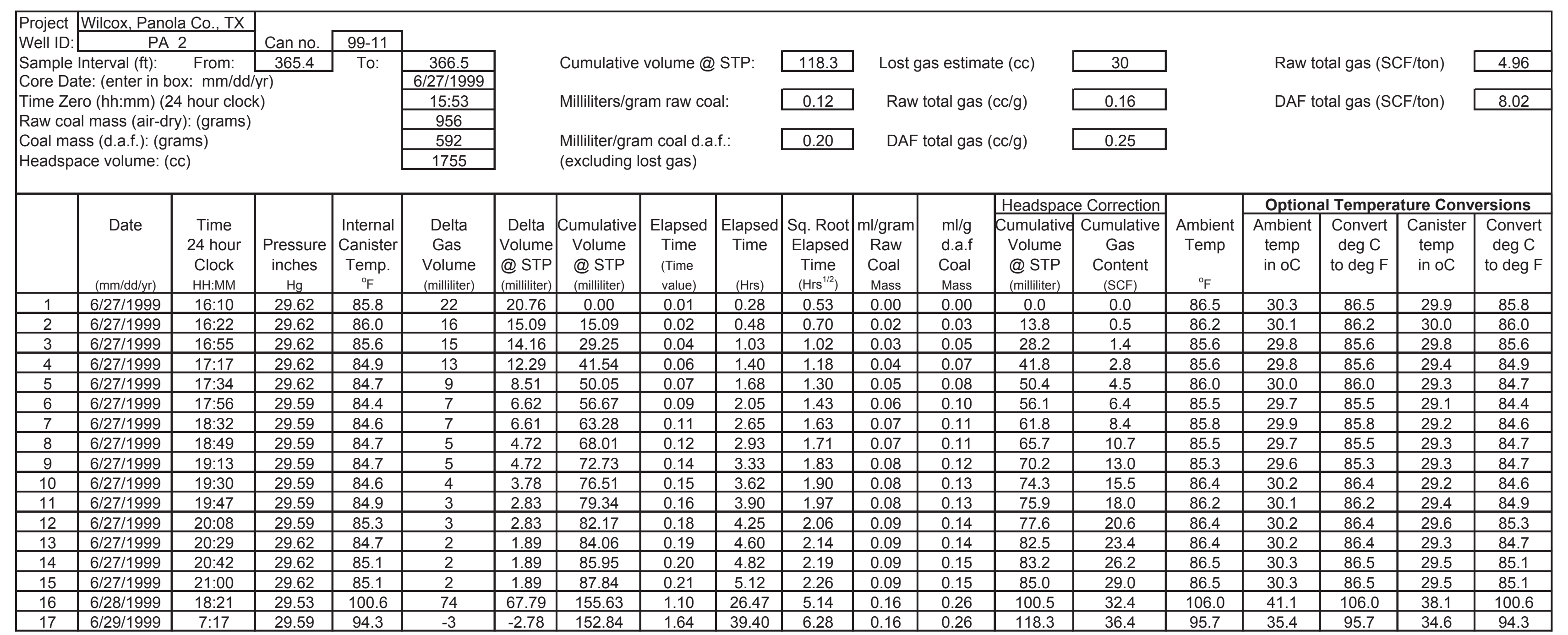




\section{Cumulative Gas Desorbed (cc) \\ (USGS-PA-2-CN12)}

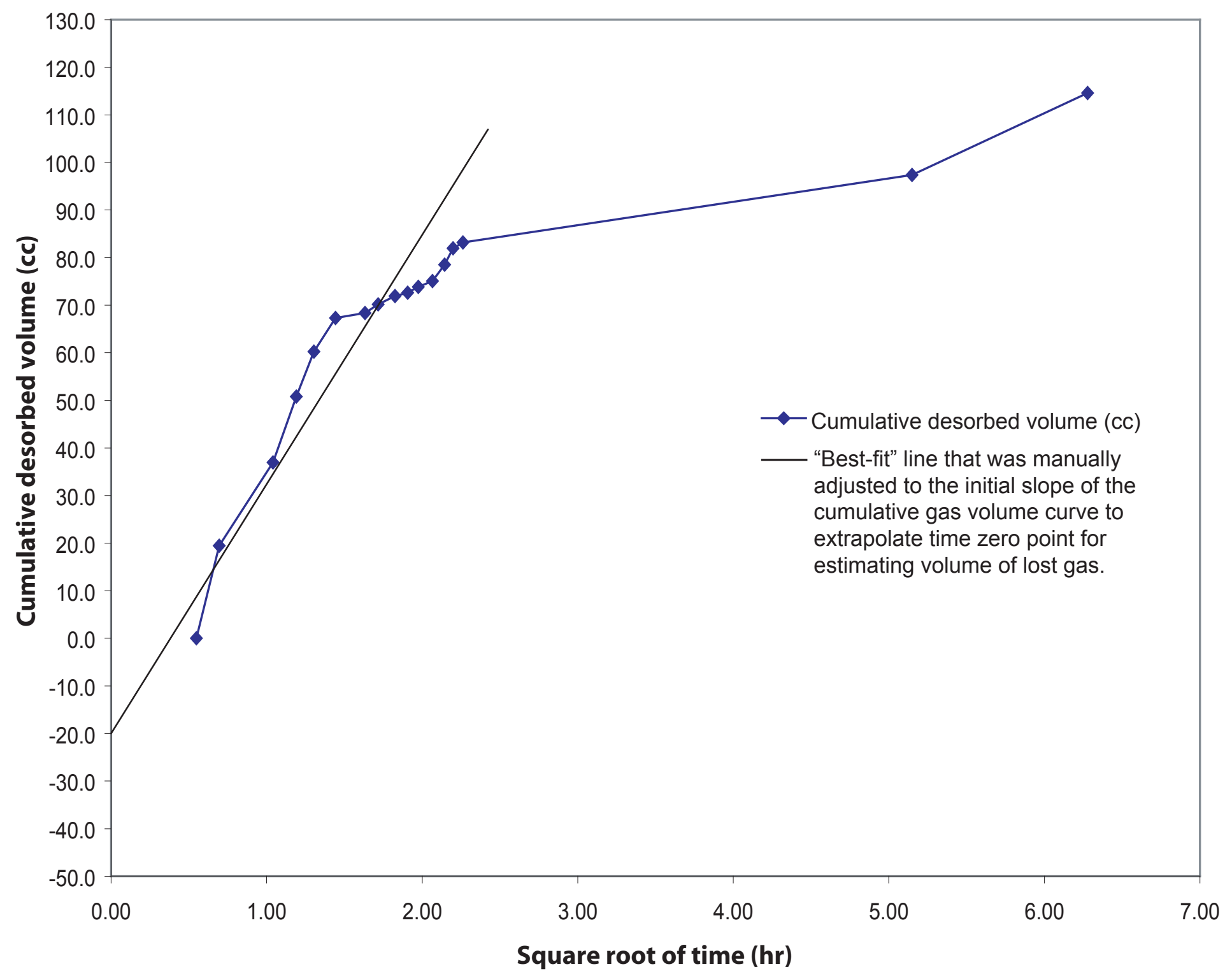

Lost Gas Estimate $=20 \mathrm{cc}$

Raw Total Gas $=\quad 0.14 \mathrm{~g} / \mathrm{cc}$ (4.63 SCF/ton)

DAF Total Gas $=\quad 0.25 \mathrm{~g} / \mathrm{cc}(8.00 \mathrm{SCF} /$ ton $)$

g/cc - grams per cubic centimeter

SCF/Ton - Standard Cubic Feet per ton

Figure 11 


\section{Table 11}

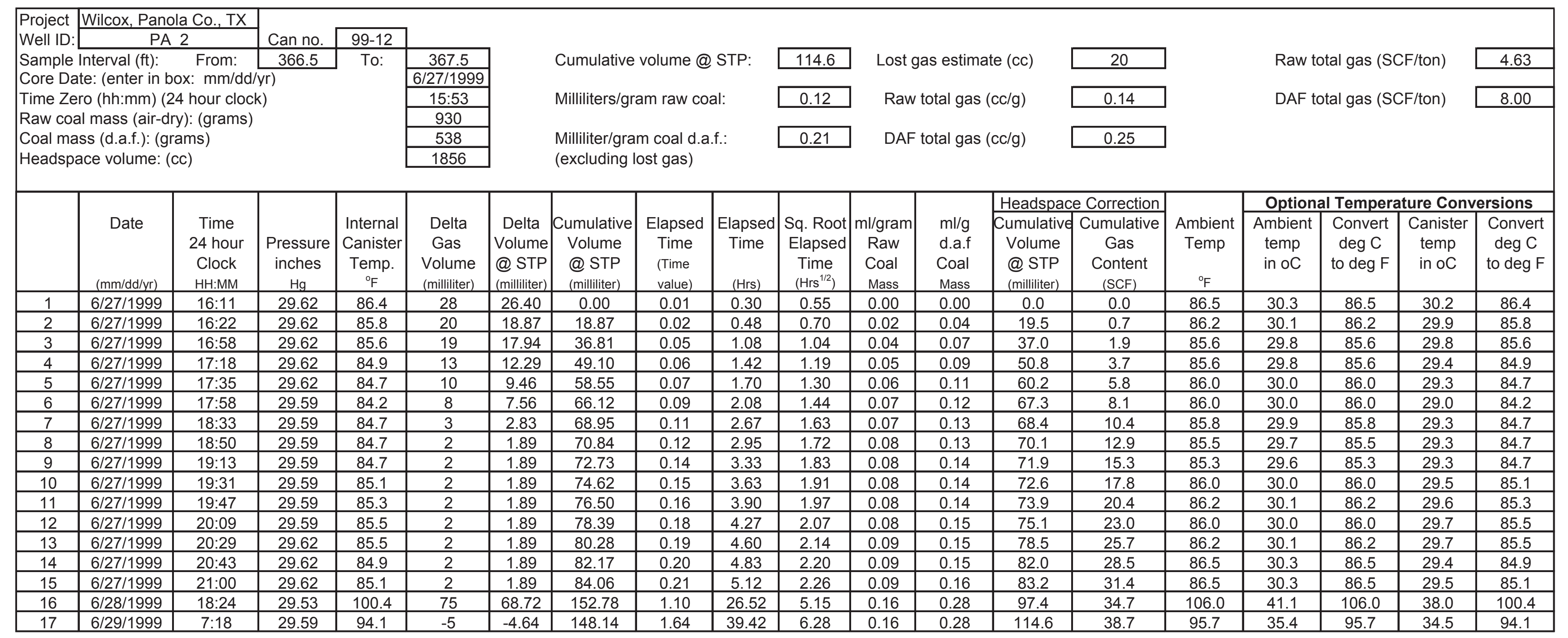




\section{Cumulative Gas Desorbed (cc) \\ (USGS-PA-2-CN13)}

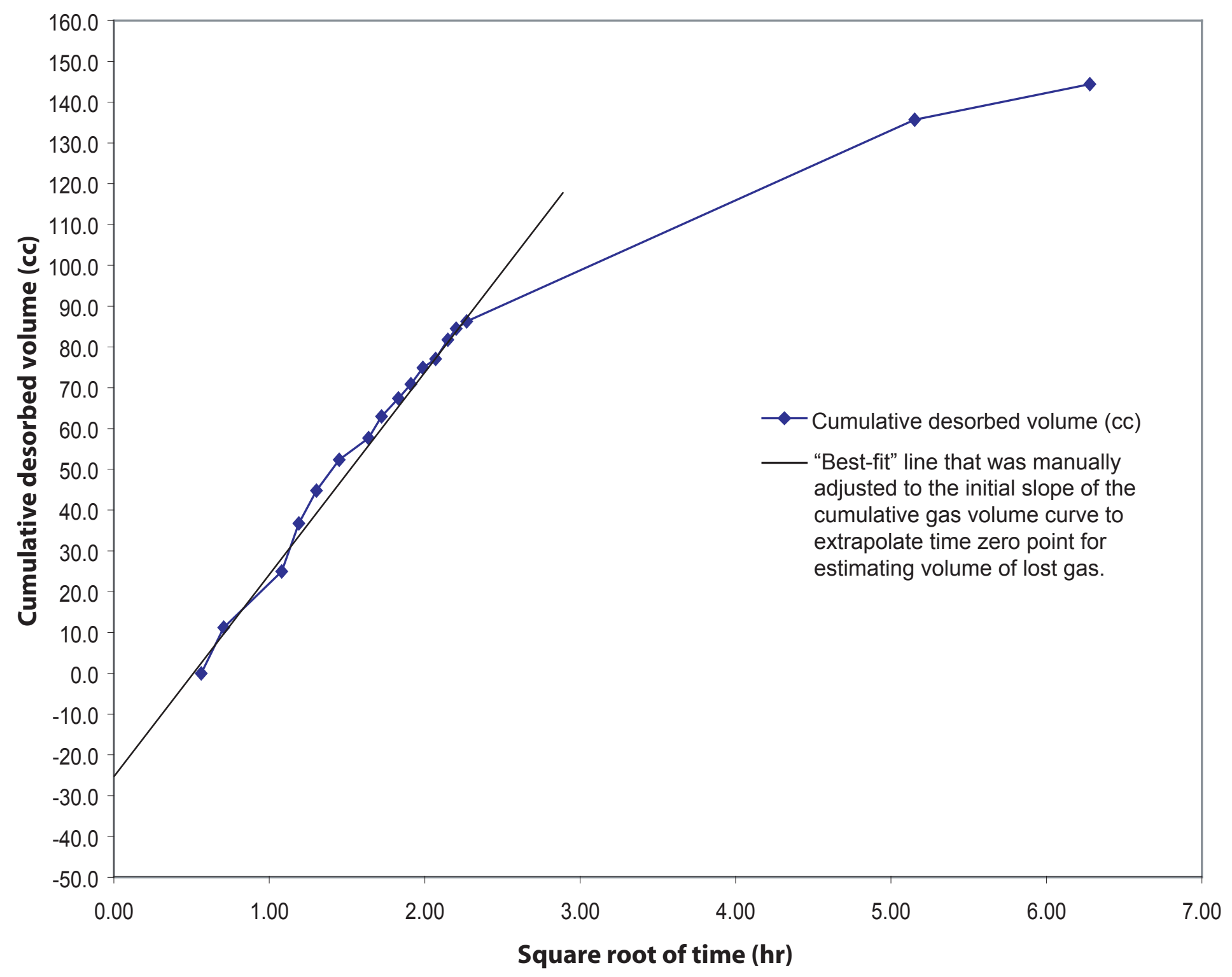

Lost Gas Estimate $=25 \mathrm{cc}$

Raw Total Gas $=\quad 0.15 \mathrm{~g} / \mathrm{cc}(4.80 \mathrm{SCF} / \mathrm{ton})$

DAF Total Gas $=\quad 0.25 \mathrm{~g} / \mathrm{cc}(8.02 \mathrm{SCF} /$ ton $)$

g/cc - grams per cubic centimeter

SCF/Ton - Standard Cubic Feet per ton

Figure 12 


\section{Cumulative Gas Desorbed (cc) \\ (USGS-PA-2-CN14)}

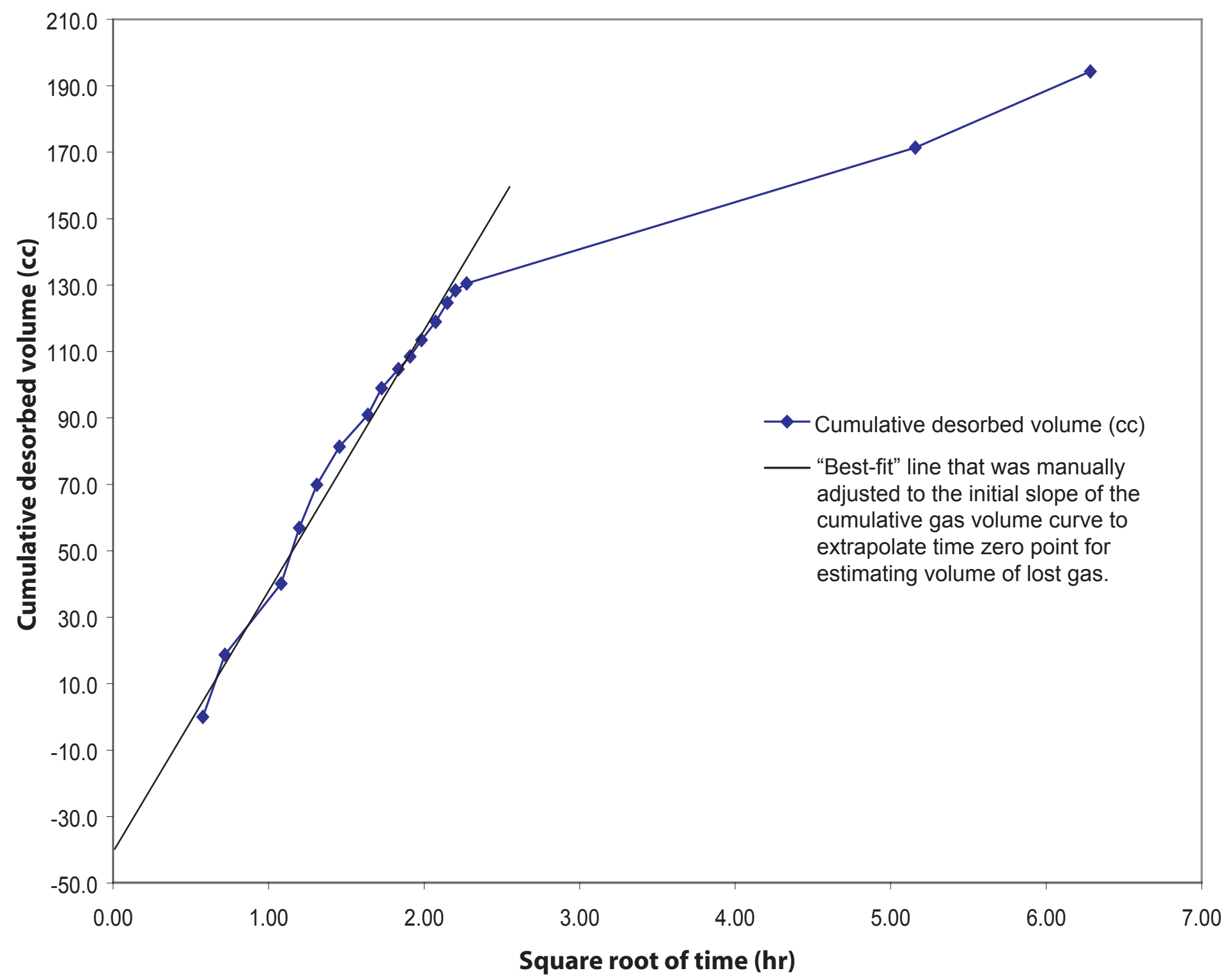

Lost Gas Estimate $=40 \mathrm{cc}$

Raw Total Gas $=\quad 0.25 \mathrm{~g} / \mathrm{cc}(7.94 \mathrm{SCF} / \mathrm{ton})$

DAF Total Gas $=\quad 0.40 \mathrm{~g} / \mathrm{cc}(12.95 \mathrm{SCF} / \mathrm{ton})$

g/cc - grams per cubic centimeter

SCF/Ton - Standard Cubic Feet per ton

Figure 13 


\section{Table 13}

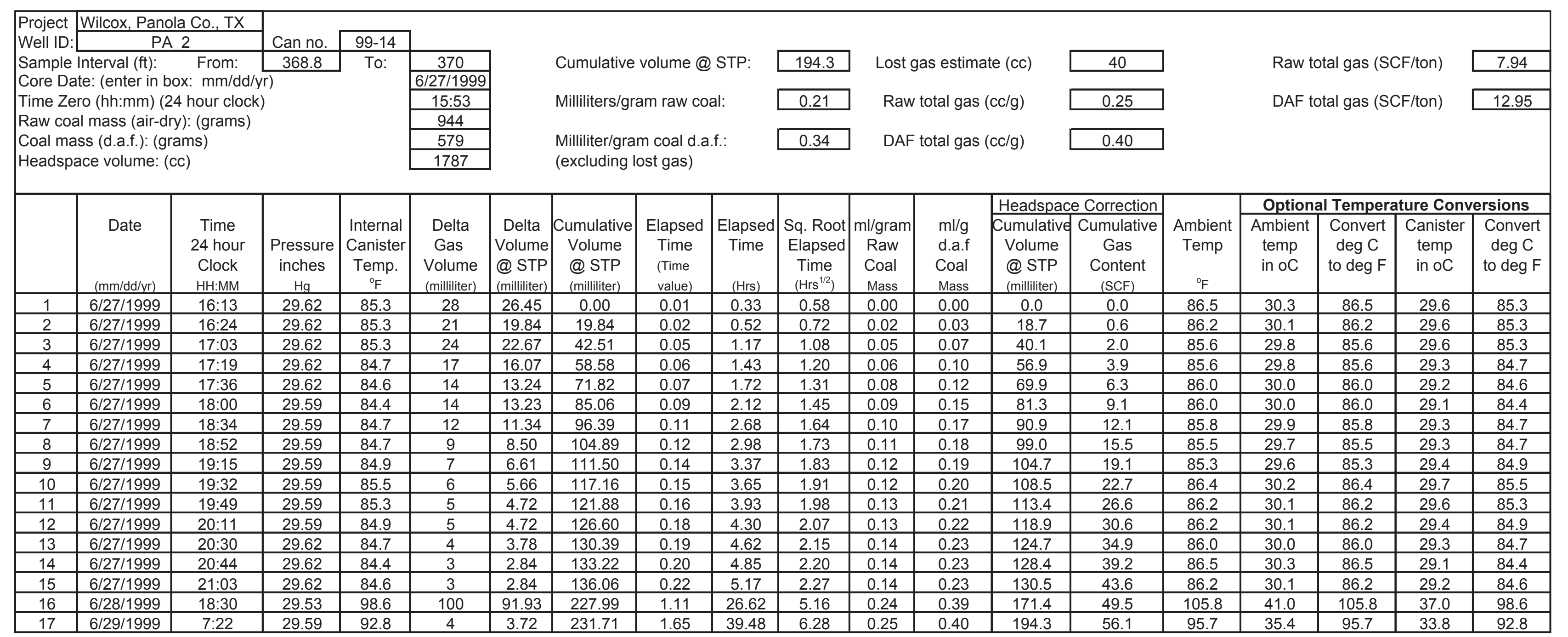




\section{Cumulative Gas Desorbed (cc) \\ (USGS-PA-2-CN15)}

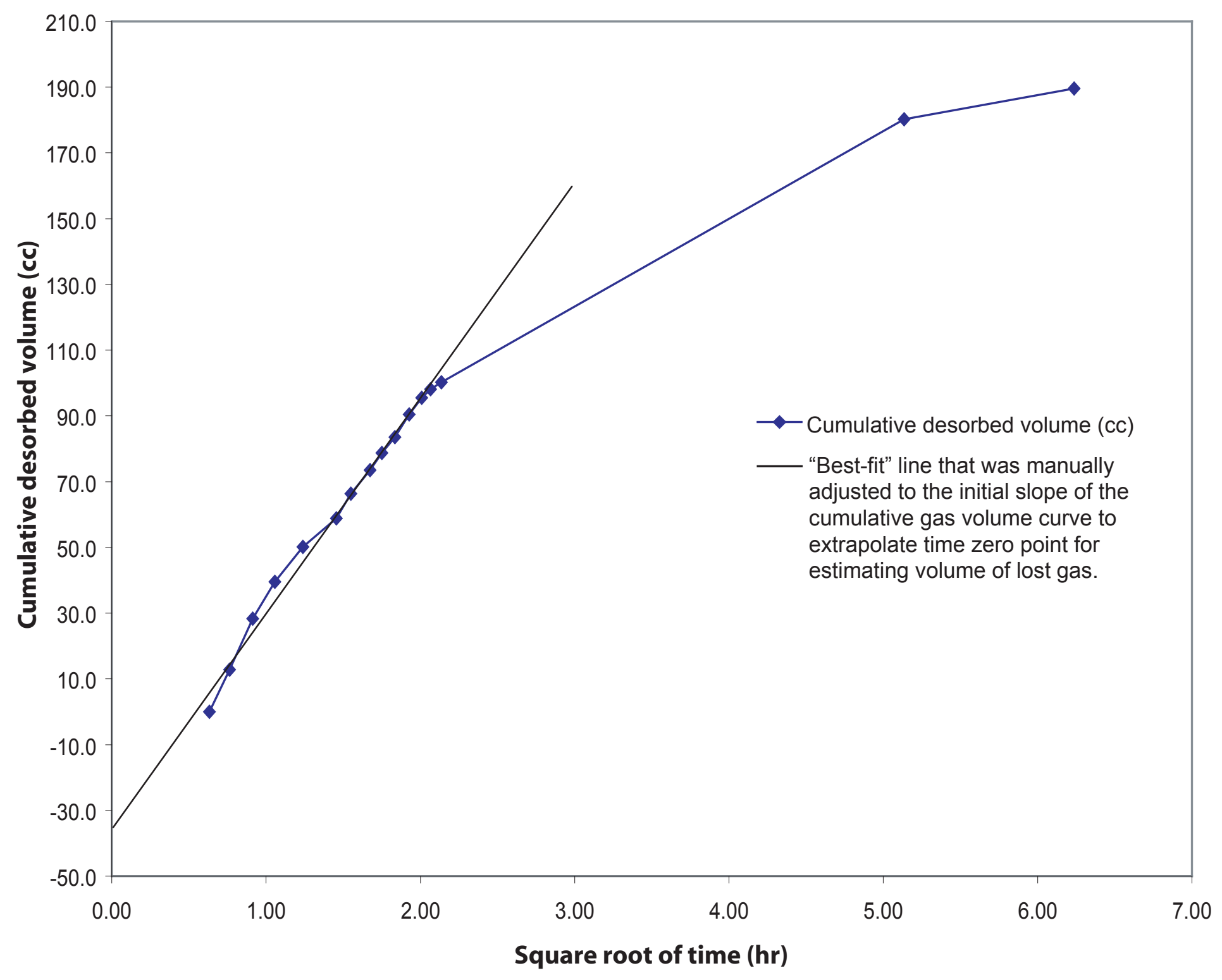

Lost Gas Estimate $=35 \mathrm{cc}$

Raw Total Gas $=\quad 0.23 \mathrm{~g} / \mathrm{cc}(7.27 \mathrm{SCF} / \mathrm{ton})$

DAF Total Gas $=\quad 0.37 \mathrm{~g} / \mathrm{cc}(11.74 \mathrm{SCF} / \mathrm{ton})$

g/cc - grams per cubic centimeter

SCF/Ton - Standard Cubic Feet per ton

Figure 14 


\section{Table 14}

\begin{tabular}{|l|l|c|c}
\hline Project & Wilcox, Panola Co., TX & \multicolumn{2}{c}{} \\
Well ID: & \multicolumn{1}{l}{ PA 2 } & Can no. & 99-15 \\
Sample Interval (ft): From: & 370 & To:
\end{tabular}

\begin{tabular}{lll|c|c|} 
Sample Interval (ft): & From: & 370 & To: & 371 \\
Core Date: (enter in box: $\mathrm{mm} / \mathrm{dd} / \mathrm{yr})$ & & $6 / 27 / 1999$ \\
\hline
\end{tabular}

Core Date: (enter in box: $\mathrm{mm} / \mathrm{dd} / \mathrm{yr})$
Time Zero (hh:mm) (24 hour clock)

Raw coal mass (air-dry): (grams)

Coal mass (d.a.f.): (grams)

Headspace volume: (cc) (excluding lost gas)
189.6 Lost gas estimate (cc)

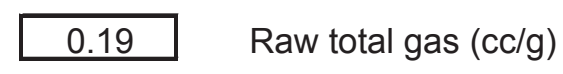

35

Raw total gas (SCF/ton)

7.27

Milliliters/gram raw coal:

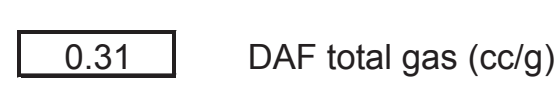

0.23

DAF total gas (SCF/ton)

11.74

Milliliter/gram coal d a f :

\begin{tabular}{|c|c|c|c|c|c|c|c|c|c|c|c|c|c|c|c|c|c|c|c|}
\hline & \multirow[b]{2}{*}{ Date } & \multirow[b]{2}{*}{$\begin{array}{c}\text { Time } \\
24 \text { hour } \\
\text { Clock } \\
\text { HH:MM }\end{array}$} & \multirow[b]{2}{*}{$\begin{array}{c}\text { Pressure } \\
\text { inches } \\
\mathrm{Hg}\end{array}$} & \multirow[b]{2}{*}{$\begin{array}{c}\text { Internal } \\
\text { Canister } \\
\text { Temp. } \\
{ }^{\circ} \mathrm{F}\end{array}$} & \multirow[b]{2}{*}{$\begin{array}{l}\text { Delta } \\
\text { Gas } \\
\text { Volume } \\
\text { (milliliter) }\end{array}$} & \multirow[b]{2}{*}{$\begin{array}{c}\text { Delta } \\
\text { Volume } \\
@ \text { STP } \\
\text { (milliliter) }\end{array}$} & \multirow[b]{2}{*}{$\begin{array}{l}\text { Cumulative } \\
\text { Volume } \\
@ \text { STP } \\
\text { (milliliter) }\end{array}$} & \multirow[b]{2}{*}{$\begin{array}{c}\text { Elapsed } \\
\text { Time } \\
\text { (Time } \\
\text { value) }\end{array}$} & \multirow[b]{2}{*}{$\begin{array}{c}\text { Elapsed } \\
\text { Time } \\
\\
(\mathrm{Hrs})\end{array}$} & \multirow[b]{2}{*}{$\begin{array}{c}\text { Sq. Root } \\
\text { Elapsed } \\
\text { Time } \\
\left(\mathrm{Hrs}^{1 / 2}\right)\end{array}$} & \multirow[b]{2}{*}{$\begin{array}{c}\mathrm{ml} / \mathrm{gram} \\
\text { Raw } \\
\text { Coal } \\
\text { Mass }\end{array}$} & \multirow[b]{2}{*}{$\begin{array}{l}\mathrm{ml} / \mathrm{g} \\
\text { d.a.f } \\
\text { Coal } \\
\text { Mass }\end{array}$} & \multicolumn{2}{|c|}{ Headspace Correction } & \multirow[b]{2}{*}{$\begin{array}{c}\text { Ambient } \\
\text { Temp } \\
{ }^{\circ} \mathrm{F} \\
\end{array}$} & \multicolumn{4}{|c|}{ Optional Temperature Conversions } \\
\hline & & & & & & & & & & & & & \begin{tabular}{|} 
Cumulative \\
Volume \\
$@$ STP \\
(milliliter)
\end{tabular} & $\begin{array}{c}\text { Cumulative } \\
\text { Gas } \\
\text { Content } \\
\text { (SCF) } \\
\end{array}$ & & $\begin{array}{l}\text { Ambient } \\
\text { temp } \\
\text { in oC }\end{array}$ & $\begin{array}{c}\text { Convert } \\
\operatorname{deg} C \\
\text { to } \operatorname{deg} F\end{array}$ & $\begin{array}{c}\text { Canister } \\
\text { temp } \\
\text { in oC }\end{array}$ & $\begin{array}{l}\text { Convert } \\
\text { deg } C \\
\text { to } \operatorname{deg} F\end{array}$ \\
\hline 1 & $6 / 27 / 1999$ & $16: 53$ & 29.62 & 84.9 & 19 & 17.96 & 0.00 & 0.02 & 0.40 & \begin{tabular}{|l|}
0.63 \\
\end{tabular} & 0.00 & 0.00 & 0.0 & 0.0 & 85.6 & 29.8 & 85.6 & 29.4 & 84.9 \\
\hline 2 & $6 / 27 / 1999$ & $17: 04$ & 29.62 & 85.5 & 16 & 15.11 & 15.11 & 0.02 & 0.58 & 0.76 & 0.02 & 0.02 & 12.8 & 0.4 & 85.6 & 29.8 & 85.6 & 29.7 & 85.5 \\
\hline 3 & $6 / 27 / 1999$ & $17: 19$ & 29.62 & 84.4 & 14 & 13.25 & 28.36 & 0.03 & 0.83 & 0.91 & 0.03 & 0.05 & 28.3 & 1.3 & 85.6 & 29.8 & 85.6 & 29.1 & 84.4 \\
\hline 4 & $6 / 27 / 1999$ & $17: 36$ & 29.62 & 84.2 & 12 & 11.36 & 39.71 & 0.05 & 1.12 & 1.06 & 0.04 & 0.06 & 39.5 & 2.6 & 86.0 & 30.0 & 86.0 & 29.0 & 84.2 \\
\hline 5 & $6 / 27 / 1999$ & 18:01 & 29.59 & 83.7 & 12 & 11.36 & 51.07 & 0.06 & 1.53 & 1.24 & 0.05 & 0.08 & 50.2 & 4.2 & 86.0 & 30.0 & 86.0 & 28.7 & 83.7 \\
\hline 6 & $6 / 27 / 1999$ & $18: 36$ & 29.59 & 84.4 & 12 & 11.34 & 62.41 & 0.09 & 2.12 & 1.45 & 0.06 & 0.10 & 58.8 & 6.1 & 85.8 & 29.9 & 85.8 & 29.1 & 84.4 \\
\hline 7 & $6 / 27 / 1999$ & $18: 53$ & 29.59 & 84.6 & 9 & 8.50 & 70.92 & 0.10 & 2.40 & 1.55 & 0.07 & 0.12 & 66.4 & 8.3 & 85.5 & 29.7 & 85.5 & 29.2 & 84.6 \\
\hline 8 & $6 / 27 / 1999$ & $19: 17$ & 29.59 & 84.6 & 8 & 7.56 & 78.48 & 0.12 & 2.80 & 1.67 & 0.08 & 0.13 & 73.5 & 10.7 & 85.3 & 29.6 & 85.3 & 29.2 & 84.6 \\
\hline 9 & $6 / 27 / 1999$ & $19: 33$ & 29.59 & 84.9 & 7 & 6.61 & 85.09 & 0.13 & 3.07 & 1.75 & 0.09 & 0.14 & 78.7 & 13.2 & 86.0 & 30.0 & 86.0 & 29.4 & 84.9 \\
\hline 10 & $6 / 27 / 1999$ & 19:51 & 29.59 & 85.1 & 6 & 5.66 & 90.75 & 0.14 & 3.37 & 1.83 & 0.09 & 0.15 & 83.6 & 15.9 & 86.2 & 30.1 & 86.2 & 29.5 & 85.1 \\
\hline 11 & $6 / 27 / 1999$ & $20: 12$ & 29.62 & 85.1 & 6 & 5.67 & 96.42 & 0.15 & 3.72 & 1.93 & 0.10 & 0.16 & 90.5 & 18.9 & 86.2 & 30.1 & 86.2 & 29.5 & 85.1 \\
\hline 12 & $6 / 27 / 1999$ & $20: 31$ & 29.62 & 84.6 & 4 & 3.78 & 100.20 & 0.17 & 4.03 & 2.01 & 0.10 & 0.16 & 95.5 & 22.0 & 86.0 & 30.0 & 86.0 & 29.2 & 84.6 \\
\hline 13 & $6 / 27 / 1999$ & $20: 45$ & 29.62 & 84.9 & 4 & 3.78 & 103.98 & 0.18 & 4.27 & 2.07 & 0.11 & 0.17 & 98.1 & 25.2 & 86.4 & 30.2 & 86.4 & 29.4 & 84.9 \\
\hline 14 & $6 / 27 / 1999$ & $21: 03$ & 29.62 & 85.1 & 3 & 2.83 & 106.82 & 0.19 & 4.57 & 2.14 & 0.11 & 0.17 & 100.3 & 28.4 & 86.4 & 30.2 & 86.4 & 29.5 & 85.1 \\
\hline 15 & $6 / 28 / 1999$ & $18: 51$ & 29.53 & 94.1 & 127 & 117.70 & 224.52 & 1.10 & 26.37 & 5.13 & 0.23 & 0.37 & 180.3 & 34.3 & 104.0 & 40.0 & 104.0 & 34.5 & 94.1 \\
\hline 16 & $6 / 29 / 1999$ & $7: 22$ & 29.59 & 90.5 & -4 & -3.74 & 220.78 & 1.62 & 38.88 & 6.24 & 0.22 & 0.36 & 189.6 & 40.4 & 95.7 & 35.4 & 95.7 & 32.5 & 90.5 \\
\hline
\end{tabular}




\section{Cumulative Gas Desorbed (cc) \\ (USGS-PA-2-CN16)}

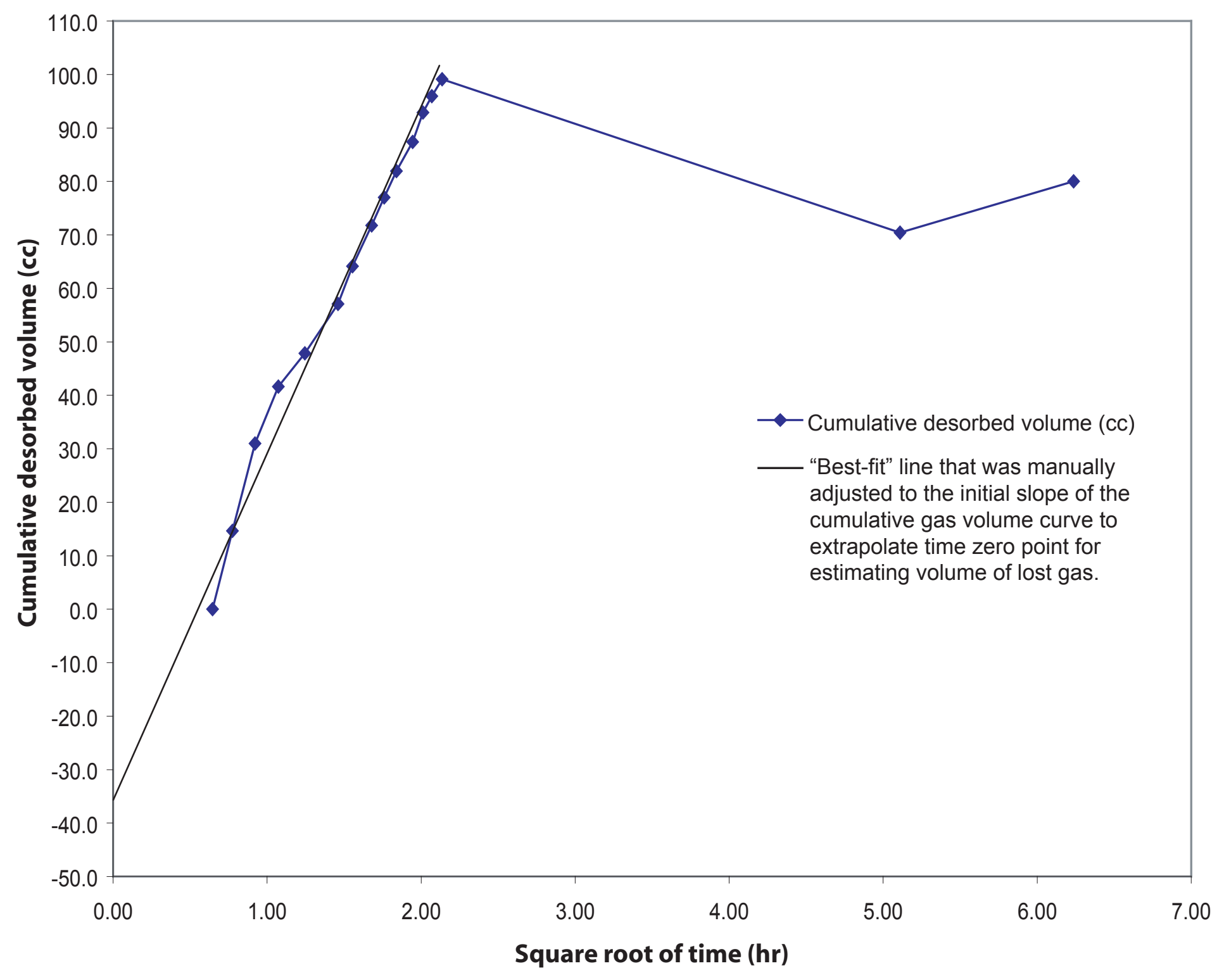

Lost Gas Estimate $=35 \mathrm{cc}$

Raw Total Gas $=\quad 0.12 \mathrm{~g} / \mathrm{cc}$ (3.91 SCF/ton)

DAF Total Gas $=\quad 0.18 \mathrm{~g} / \mathrm{cc}(5.73 \mathrm{SCF} / \mathrm{ton})$

g/cc - grams per cubic centimeter

SCF/Ton - Standard Cubic Feet per ton

Figure 15 


\section{Table 15}

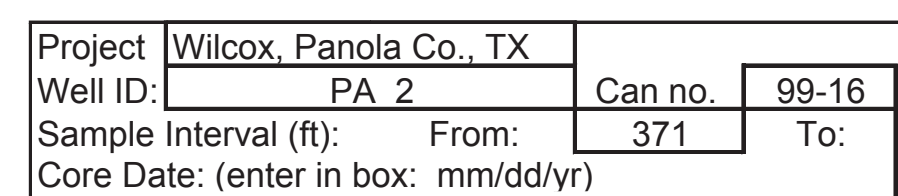

Time Zero (hh:mm) (24 hour clock)

Raw coal mass (air-dry): (grams)

Coal mass (d.a.f.): (grams)

Headspace volume: (cc)

\begin{tabular}{|c|c|c|c|c|c|c|c|c|c|c|c|c|c|c|c|c|c|c|c|}
\hline & \multirow[b]{2}{*}{ Date } & \multirow[b]{2}{*}{$\begin{array}{c}\text { Time } \\
24 \text { hour } \\
\text { Clock } \\
\text { HH:MM }\end{array}$} & \multirow[b]{2}{*}{$\begin{array}{c}\text { Pressure } \\
\text { inches } \\
\mathrm{Hg}\end{array}$} & \multirow[b]{2}{*}{$\begin{array}{c}\text { Internal } \\
\text { Canister } \\
\text { Temp. } \\
{ }^{\circ} \mathrm{F}\end{array}$} & \multirow[b]{2}{*}{$\begin{array}{l}\text { Delta } \\
\text { Gas } \\
\text { Volume } \\
\text { (milliliter) }\end{array}$} & \multirow[b]{2}{*}{\begin{tabular}{|c|} 
Delta \\
Volume \\
$@$ STP \\
(milliliter) \\
\end{tabular}} & \multirow[b]{2}{*}{$\begin{array}{c}\text { Cumulative } \\
\text { Volume } \\
@ \text { STP } \\
\text { (milliliter) }\end{array}$} & \multirow[b]{2}{*}{\begin{tabular}{|c} 
Elapsed \\
Time \\
(Time \\
value)
\end{tabular}} & \multirow[b]{2}{*}{$\begin{array}{c}\text { Elapsed } \\
\text { Time }\end{array}$} & \multirow[b]{2}{*}{$\begin{array}{c}\text { Sq. Root } \\
\text { Elapsed } \\
\text { Time } \\
\left(\mathrm{Hrs}^{1 / 2}\right)\end{array}$} & \multirow[b]{2}{*}{$\begin{array}{c}\text { ml/gram } \\
\text { Raw } \\
\text { Coal } \\
\text { Mass }\end{array}$} & \multirow[b]{2}{*}{$\begin{array}{l}\mathrm{ml} / \mathrm{g} \\
\text { d.a.f } \\
\text { Coal } \\
\text { Mass }\end{array}$} & \multicolumn{2}{|c|}{ Headspace Correction } & \multirow[b]{2}{*}{$\begin{array}{c}\text { Ambient } \\
\text { Temp } \\
{ }^{\circ} \mathrm{F} \\
\end{array}$} & \multicolumn{4}{|c|}{ Optional Temperature Conversions } \\
\hline & & & & & & & & & & & & & \begin{tabular}{|c|} 
Cumulative \\
Volume \\
$@$ STP \\
(milliliter)
\end{tabular} & $\begin{array}{c}\text { Cumulative } \\
\text { Gas } \\
\text { Content } \\
\text { (SCF) }\end{array}$ & & $\begin{array}{c}\text { Ambient } \\
\text { temp } \\
\text { in oC }\end{array}$ & $\begin{array}{l}\text { Convert } \\
\text { deg C } \\
\text { to deg F }\end{array}$ & $\begin{array}{c}\text { Canister } \\
\text { temp } \\
\text { in oC }\end{array}$ & $\begin{array}{l}\text { Convert } \\
\text { deg } \mathrm{C} \\
\text { to deg } \mathrm{F}\end{array}$ \\
\hline 1 & $6 / 27 / 1999$ & $16: 54$ & 29.62 & 84.4 & 24 & \begin{tabular}{|l|}
22.71 \\
\end{tabular} & 0.00 & 0.02 & 0.42 & 0.65 & 0.00 & 0.00 & \begin{tabular}{|l|}
0.0 \\
\end{tabular} & 0.0 & 85.6 & 29.8 & 85.6 & 29.1 & 84.4 \\
\hline 2 & $6 / 27 / 1999$ & $17: 05$ & 29.62 & 84.9 & 18 & 17.01 & 17.01 & 0.02 & 0.60 & 0.77 & 0.02 & 0.02 & 14.6 & 0.4 & 85.6 & 29.8 & 85.6 & 29.4 & 84.9 \\
\hline 3 & $6 / 27 / 1999$ & $17: 20$ & 29.62 & 83.5 & 14 & 13.27 & 30.28 & 0.04 & 0.85 & 0.92 & 0.03 & 0.04 & 31.0 & 1.3 & 85.6 & 29.8 & 85.6 & 28.6 & 83.5 \\
\hline 4 & $6 / 27 / 1999$ & $17: 38$ & 29.62 & 83.8 & 13 & 12.31 & 42.60 & 0.05 & 1.15 & 1.07 & 0.04 & 0.06 & 41.6 & 2.5 & 86.0 & 30.0 & 86.0 & 28.8 & 83.8 \\
\hline 5 & $6 / 27 / 1999$ & $18: 02$ & 29.52 & 83.7 & 12 & 11.33 & 53.93 & 0.06 & 1.55 & 1.24 & 0.05 & 0.07 & 47.8 & 3.9 & 86.0 & 30.0 & 86.0 & 28.7 & 83.7 \\
\hline 6 & $6 / 27 / 1999$ & $18: 37$ & 29.52 & 84.2 & 12 & 11.32 & 65.25 & 0.09 & 2.13 & 1.46 & 0.06 & 0.09 & 57.1 & 5.6 & 85.8 & 29.9 & 85.8 & 29.0 & 84.2 \\
\hline 7 & $6 / 27 / 1999$ & $18: 54$ & 29.52 & 84.6 & 9 & 8.48 & 73.73 & 0.10 & 2.42 & 1.55 & 0.07 & 0.10 & 64.1 & 7.5 & 85.5 & 29.7 & 85.5 & 29.2 & 84.6 \\
\hline 8 & $6 / 27 / 1999$ & $19: 18$ & 29.52 & 84.4 & 8 & 7.54 & 81.27 & 0.12 & 2.82 & 1.68 & 0.07 & 0.11 & 71.7 & 9.6 & 85.3 & 29.6 & 85.3 & 29.1 & 84.4 \\
\hline 9 & $6 / 27 / 1999$ & $19: 35$ & 29.52 & 84.7 & 7 & 6.60 & 87.87 & 0.13 & 3.10 & 1.76 & 0.08 & 0.12 & 77.0 & 11.8 & 86.4 & 30.2 & 86.4 & 29.3 & 84.7 \\
\hline 10 & $6 / 27 / 1999$ & $19: 52$ & 29.59 & 86.2 & 6 & 5.65 & 93.52 & 0.14 & 3.38 & 1.84 & 0.09 & 0.12 & 82.0 & 14.2 & 86.2 & 30.1 & 86.2 & 30.1 & 86.2 \\
\hline 11 & $6 / 27 / 1999$ & $20: 16$ & 29.62 & 86.4 & 5 & 4.71 & 98.24 & 0.16 & 3.78 & 1.95 & 0.09 & 0.13 & 87.4 & 16.8 & 86.2 & 30.1 & 86.2 & 30.2 & 86.4 \\
\hline 12 & $6 / 27 / 1999$ & $20: 32$ & 29.62 & 85.6 & 4 & 3.78 & 102.01 & 0.17 & 4.05 & 2.01 & 0.09 & 0.14 & 92.9 & 19.5 & 86.0 & 30.0 & 86.0 & 29.8 & 85.6 \\
\hline 13 & $6 / 27 / 1999$ & $20: 46$ & 29.62 & 85.8 & 4 & 3.77 & 105.79 & 0.18 & 4.28 & 2.07 & 0.10 & 0.14 & 96.0 & 22.3 & 86.4 & 30.2 & 86.4 & 29.9 & 85.8 \\
\hline 14 & $6 / 27 / 1999$ & $21: 03$ & 29.62 & 85.6 & 3 & 2.83 & 108.62 & 0.19 & 4.57 & 2.14 & 0.10 & 0.15 & 99.1 & 25.2 & 86.2 & 30.1 & 86.2 & 29.8 & 85.6 \\
\hline 15 & $6 / 28 / 1999$ & $18: 35$ & 29.53 & 95.0 & 0 & 0.00 & 108.62 & 1.09 & 26.10 & 5.11 & 0.10 & 0.15 & 70.4 & 27.2 & 104.0 & 40.0 & 104.0 & 35.0 & 95.0 \\
\hline 16 & $6 / 29 / 1999$ & $7: 23$ & 29.59 & 91.0 & -4 & -3.74 & 104.88 & 1.62 & 38.90 & 6.24 & 0.10 & 0.14 & 80.0 & 29.6 & 95.7 & 35.4 & 95.7 & 32.8 & 91.0 \\
\hline
\end{tabular}




\section{Cumulative Gas Desorbed (cc) (USGS-PA-2-CN17)}

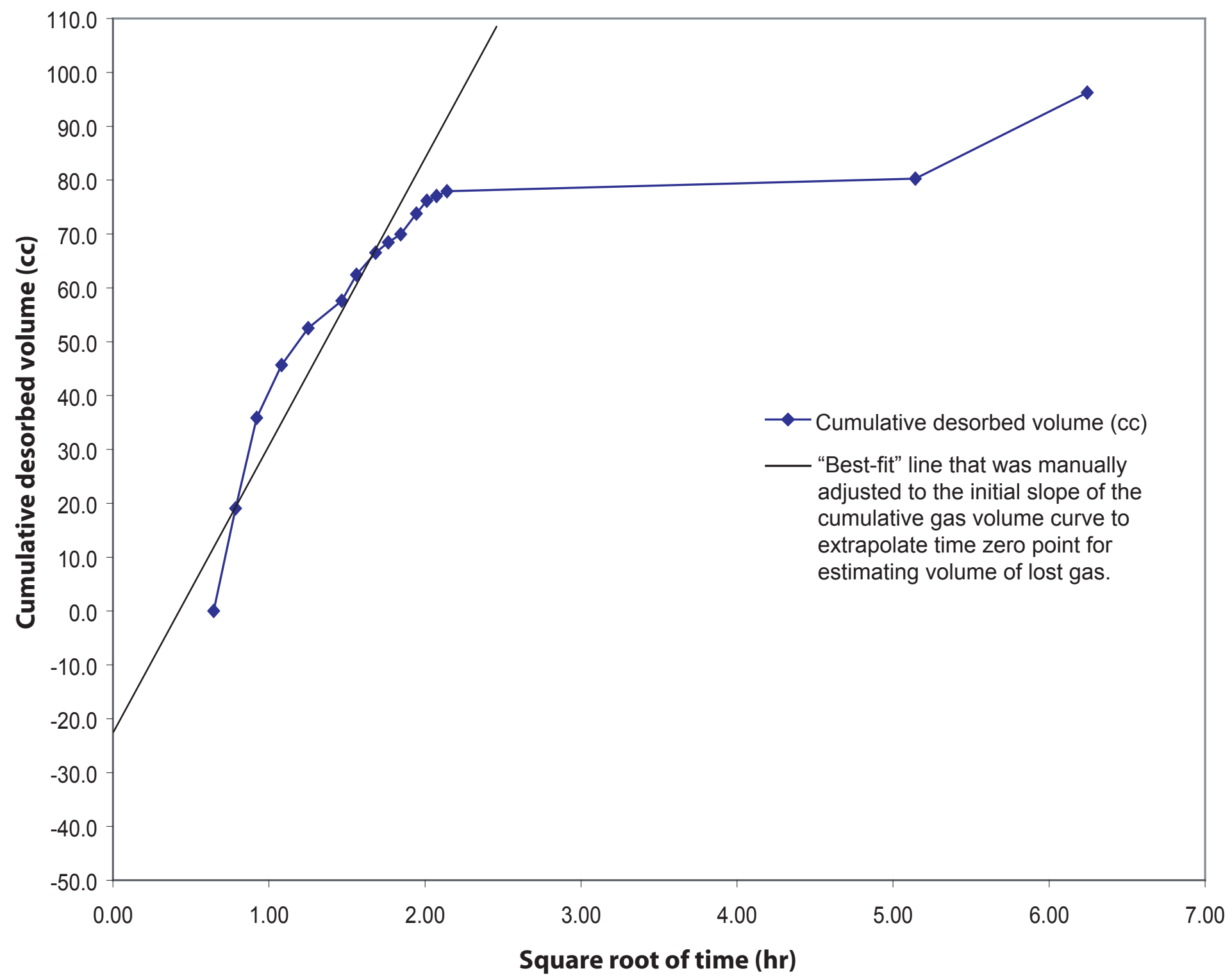

Lost Gas Estimate $=23 \mathrm{cc}$

Raw Total Gas $=\quad 0.15 \mathrm{~g} / \mathrm{cc}(4.89 \mathrm{SCF} / \mathrm{ton})$

DAF Total Gas $=\quad 0.24 \mathrm{~g} / \mathrm{cc}(7.79 \mathrm{SCF} /$ ton $)$

g/cc - grams per cubic centimeter

SCF/Ton - Standard Cubic Feet per ton

Figure 16 
Table 16

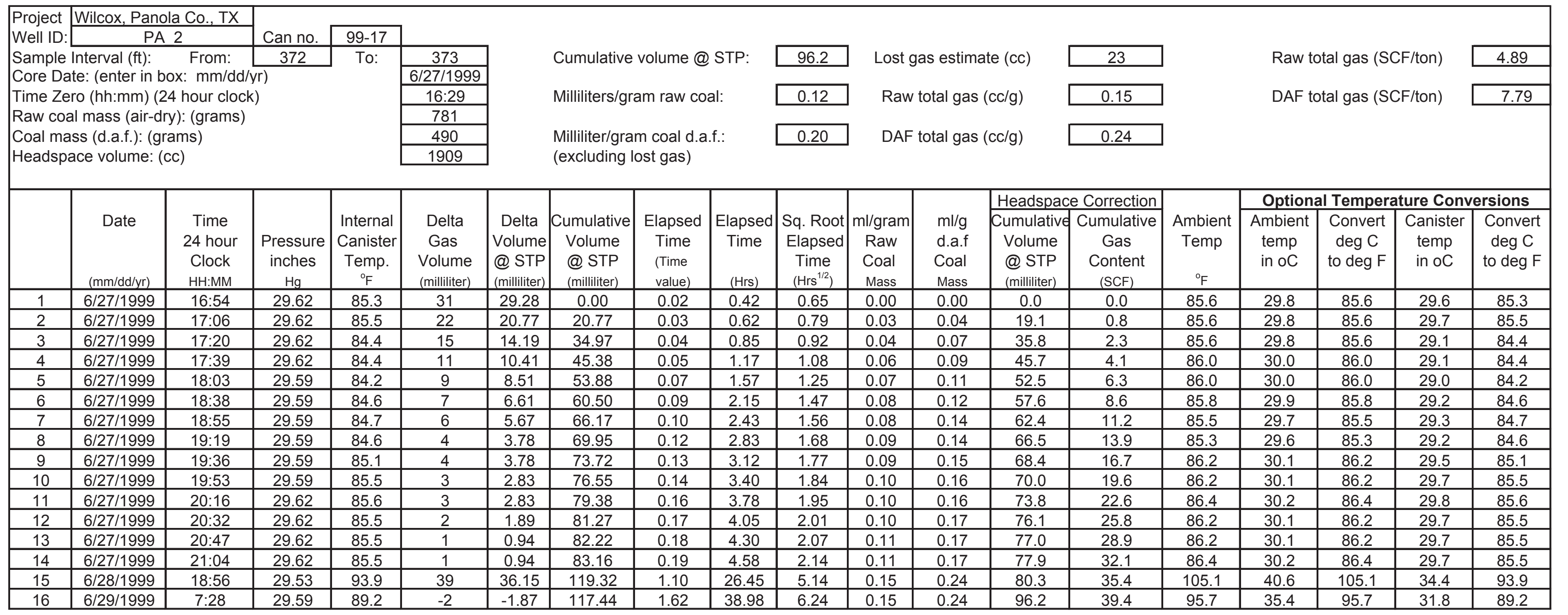




\section{Appendix 1}

\section{Coal chemistry data from boreholes USGS-PA-1 and USGS-PA-2}

Appendix 1 of

Results of coalbed methane drilling in Panola County, Texas

Edited By Peter D. Warwick ${ }^{1}$, John R. SanFilipo ${ }^{1}$, Alex W. Karlsen ${ }^{1}$, and Charles E. Barker ${ }^{2}$

'U.S. Geological Survey, Reston, VA

${ }^{2}$ U.S. Geological Survey, Denver, CO

Open-File Report 2005-1046

U.S. Department of the Interior

U.S. Geological Survey 


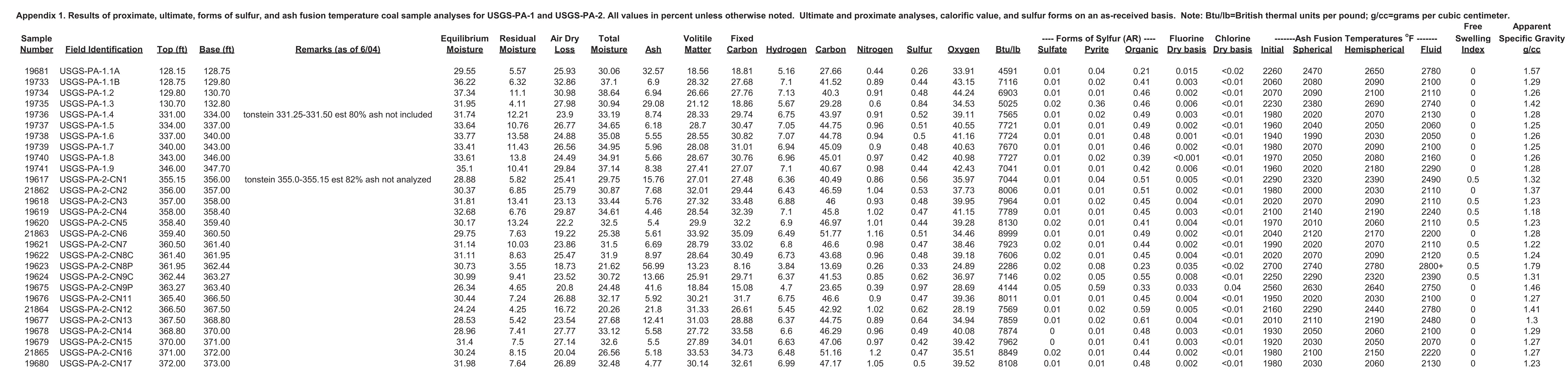




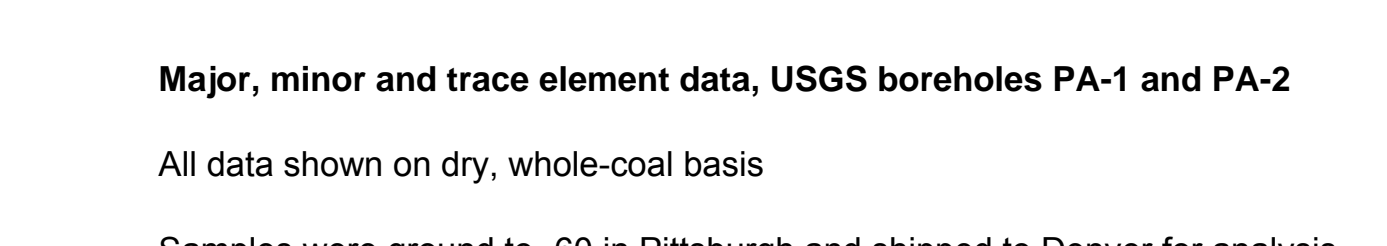
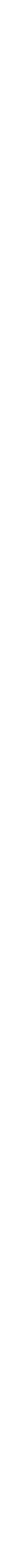


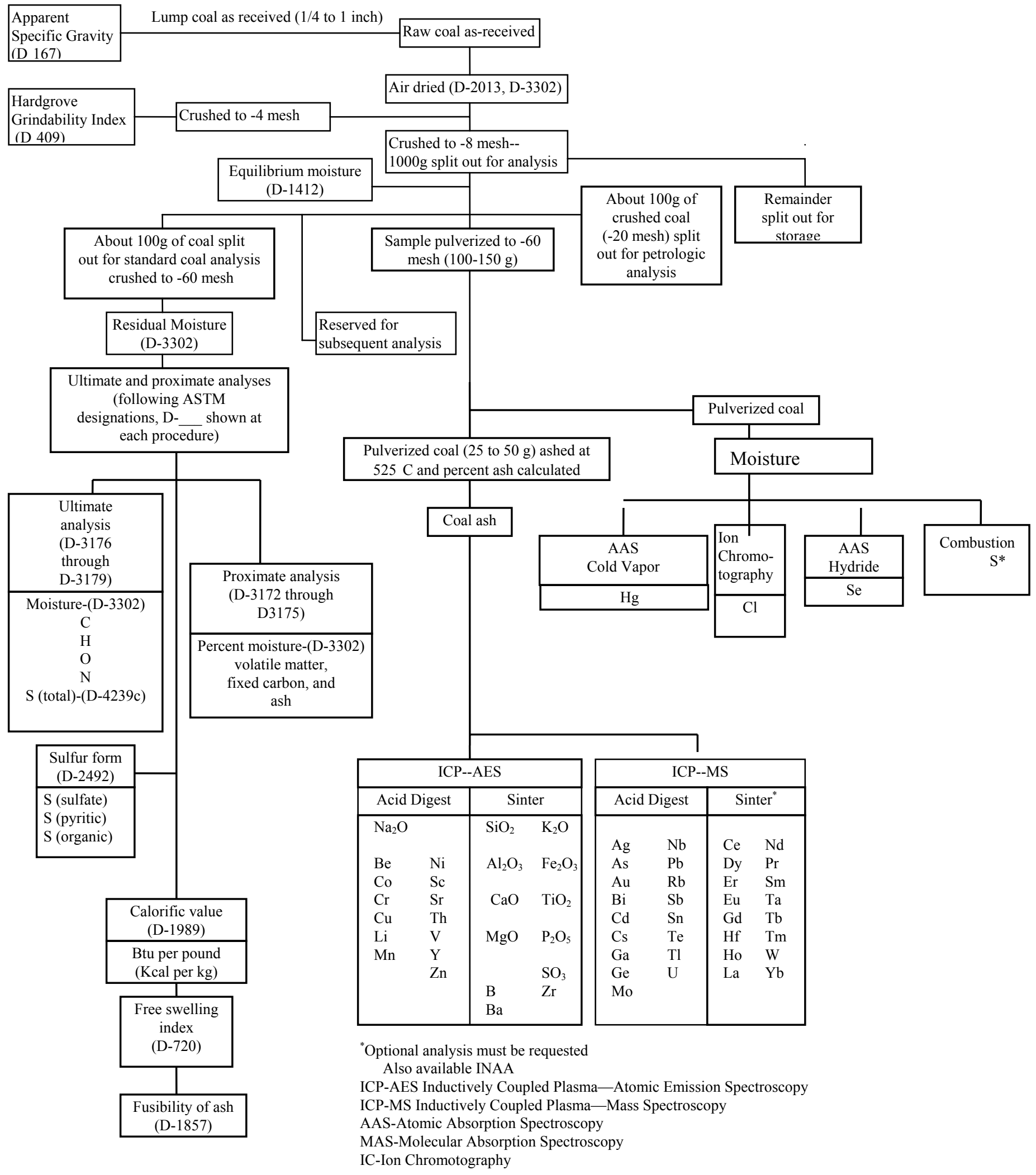

Figure 1. Flow diagram of procedures used after December 1994, for the analysis of coal samples collected. (Current ASTM procedures effective July, 1991)

(ASTM-American Society for Testing and Materials, USGS-United States Geological Survey.) 


\section{Appendix 2}

\section{Methane adsorption data from borehole USGS-PA-2}

Appendix 2 of

Results of coalbed methane drilling in Panola County, Texas

Edited By Peter D. Warwick', John R. SanFilipo', Alex W. Karlsen', and Charles E. Barker

'U.S. Geological Survey, Reston, VA

${ }^{2}$ U.S. Geological Survey, Denver, CO

Open-File Report 2005-1046

U.S. Department of the Interior

U.S. Geological Survey 


\section{USGS-PA-2-CN2}

Methane Adsorption Isotherms

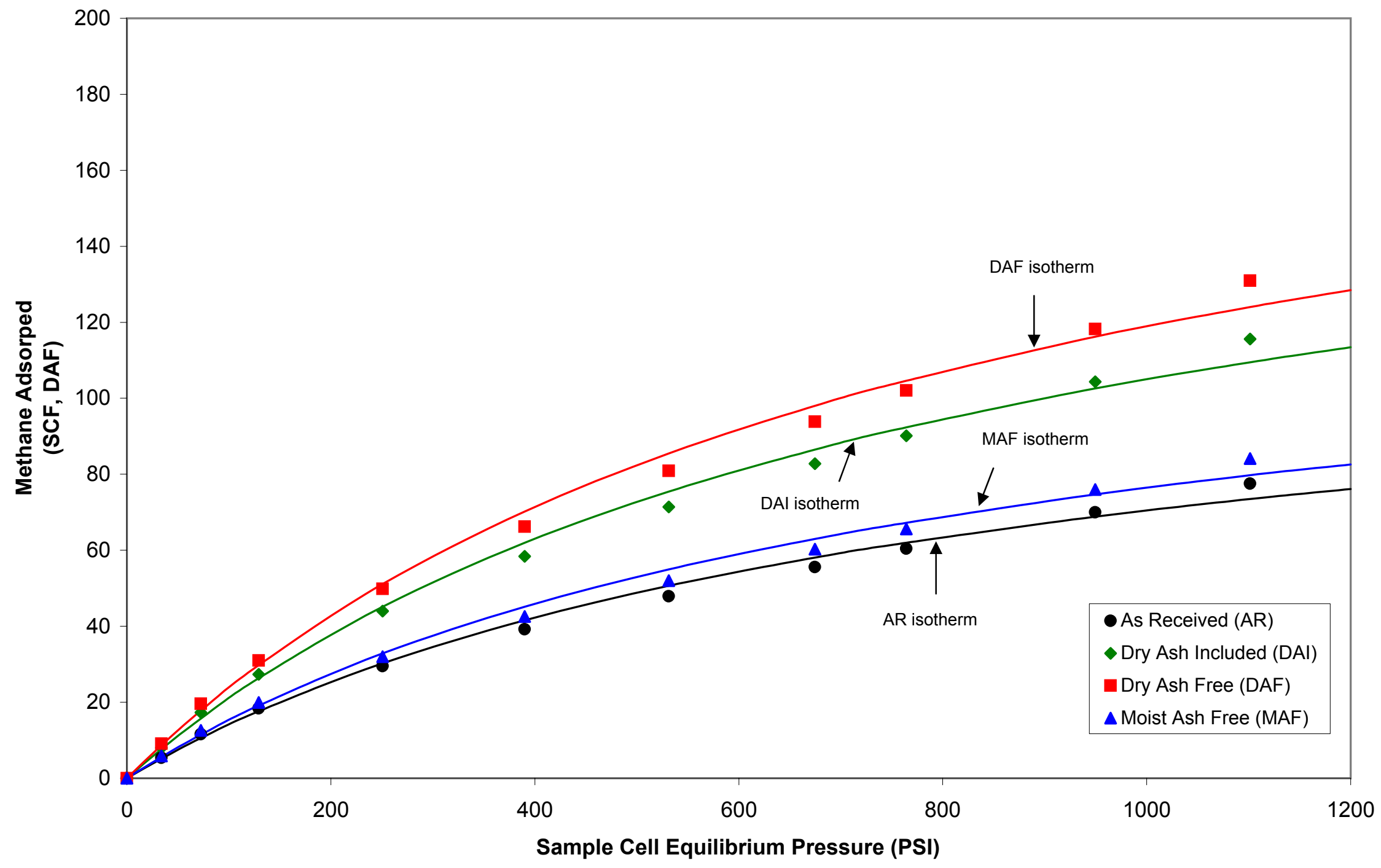


USGS-PA-2-CN2

METHANE ADSORPTION ISOTHERM CFG UNITS

Sample I.D. : $\quad$ USGS-PA-2-CN2

Isotherm Temperature ${ }^{\circ} \mathrm{F}: \quad 86$

Moisture Content (EQ) \% :

AS RECEIVED BASIS

PRESSURE (PSI)
34
73
129
251
390
531
675
764
950
1101

$\begin{array}{cc}\text { ADSORPED METHANE (SCF/ton) } & \mathbf{P} / \mathbf{V} \\ 5.4 & 6.29 \\ 11.6 & 6.25 \\ 18.4 & 7.04 \\ 29.5 & 8.50 \\ 39.2 & 9.95 \\ 47.9 & 11.09 \\ 55.6 & 12.15 \\ 60.5 & 12.64 \\ 70.0 & 13.57 \\ 77.5 & 14.20\end{array}$

Saturated Monolayer Volume (SCF/ton, as-received):

\section{DRY ASH FREE BASIS}

PRESSURE (PSI)
34
73
129
251
390
531
675
764
950
1101

$\begin{array}{cc}\text { ADSORPED METHANE (SCF/ton) } & \mathbf{P} / \mathbf{V} \\ 9.1 & 3.73 \\ 19.6 & 3.70 \\ 31.0 & 4.17 \\ 49.8 & 5.03 \\ 66.2 & 5.89 \\ 80.9 & 6.57 \\ 93.8 & 7.19 \\ 102.1 & 7.49 \\ 118.2 & 8.03 \\ 130.9 & 8.41\end{array}$

Saturated Monolayer Volume (SCF/ton, daf):

DRY ASH INCLUDED BASIS

PRESSURE (PSI)
34
73
129
251
390
531
675
764
950
1101

$\begin{array}{cc}\text { ADSORPED METHANE (SCF/ton) } & \mathbf{P} / \mathbf{V} \\ 8.0 & 4.22 \\ 17.3 & 4.19 \\ 27.4 & 4.72 \\ 44.0 & 5.70 \\ 58.4 & 6.68 \\ 71.4 & 7.44 \\ 82.8 & 8.15 \\ 90.1 & 8.48 \\ 104.3 & 9.10 \\ 115.6 & 9.53\end{array}$

Saturated Monolayer Volume (SCF/ton, dai):

MOIST ASH FREE BASIS

PRESSURE (PSI)
34
73
129
251
390
531
675
764
950
1101

$\begin{array}{cc}\text { ADSORPED METHANE (SCF/ton) } & \mathbf{P} / \mathbf{V} \\ 5.8 & 5.80 \\ 12.6 & 5.75 \\ 19.9 & 6.48 \\ 32.0 & 7.83 \\ 42.6 & 9.17 \\ 52.0 & 10.22 \\ 60.3 & 11.19 \\ 65.6 & 11.65 \\ 76.0 & 12.50 \\ 84.2 & 13.08\end{array}$




\section{USGS-PA-2-CN6}

Methane Adsorption Isotherms

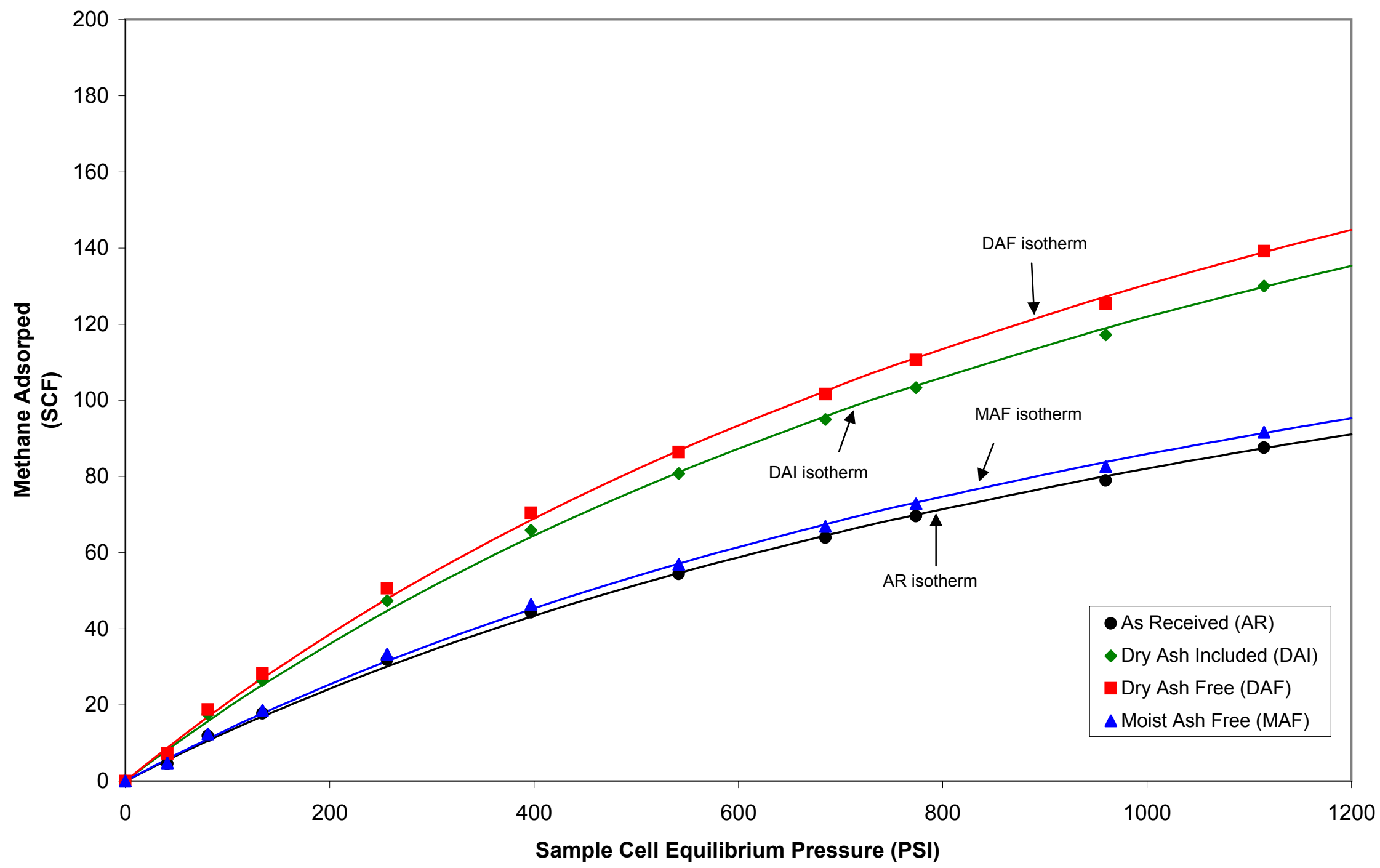


Sample I.D. :

USGS-PA2-CN6

Isotherm Temperature $^{\circ} \mathrm{F}: \quad 86$

Correlation Coefficient: $\quad 0.90$
Moisture Content (EQ) \% : $\quad 32.67$

Dry Ash Content, \% :

Helium Density g/cc

AS RECEIVED BASIS

PRESSURE (PSI)
41
81
134
256
397
542
685
774
960
1114

ADSORPED METHANE (SCF/ton)

Saturated Monolayer Volume (SCF/ton, as-received):

DRY ASH FREE BASIS

PRESSURE (PSI)
41
81
134
256
397
542
685
774
960
1114

ADSORPED METHANE (SCF/ton)

Saturated Monolayer Volume (SCF/ton, daf):

\section{DRY ASH INCLUDED BASIS}

PRESSURE (PSI)
41
81
134
256
397
542
685
774
960
1114

$\begin{array}{cc}\text { ADSORPED METHANE (SCF/ton) } & \mathbf{P} / \mathbf{V} \\ 6.8 & 6.05 \\ 17.6 & 4.60 \\ 26.4 & 5.08 \\ 47.3 & 5.41 \\ 65.9 & 6.03 \\ 80.8 & 6.70 \\ 95.0 & 7.21 \\ 103.3 & 7.49 \\ 117.2 & 8.19 \\ 130.0 & 8.57\end{array}$

Saturated Monolayer Volume (SCF/ton, dai):

\section{MOIST ASH FREE BASIS}

PRESSURE (PSI)
41
81
134
256
397
542
685
774
960
1114

$\begin{array}{cc}\text { ADSORPED METHANE (SCF/ton) } & \mathbf{P} / \mathbf{V} \\ 4.8 & 8.59 \\ 12.4 & 6.53 \\ 18.6 & 7.22 \\ 33.3 & 7.68 \\ 46.4 & 8.56 \\ 56.9 & 9.52 \\ 66.9 & 10.24 \\ 72.8 & 10.63 \\ 82.6 & 11.62 \\ 91.6 & 12.17\end{array}$

Saturated Monolayer Volume (SCF/ton, maf): 
USGS-PA-2-CN12

Methane Adsorption Isotherms

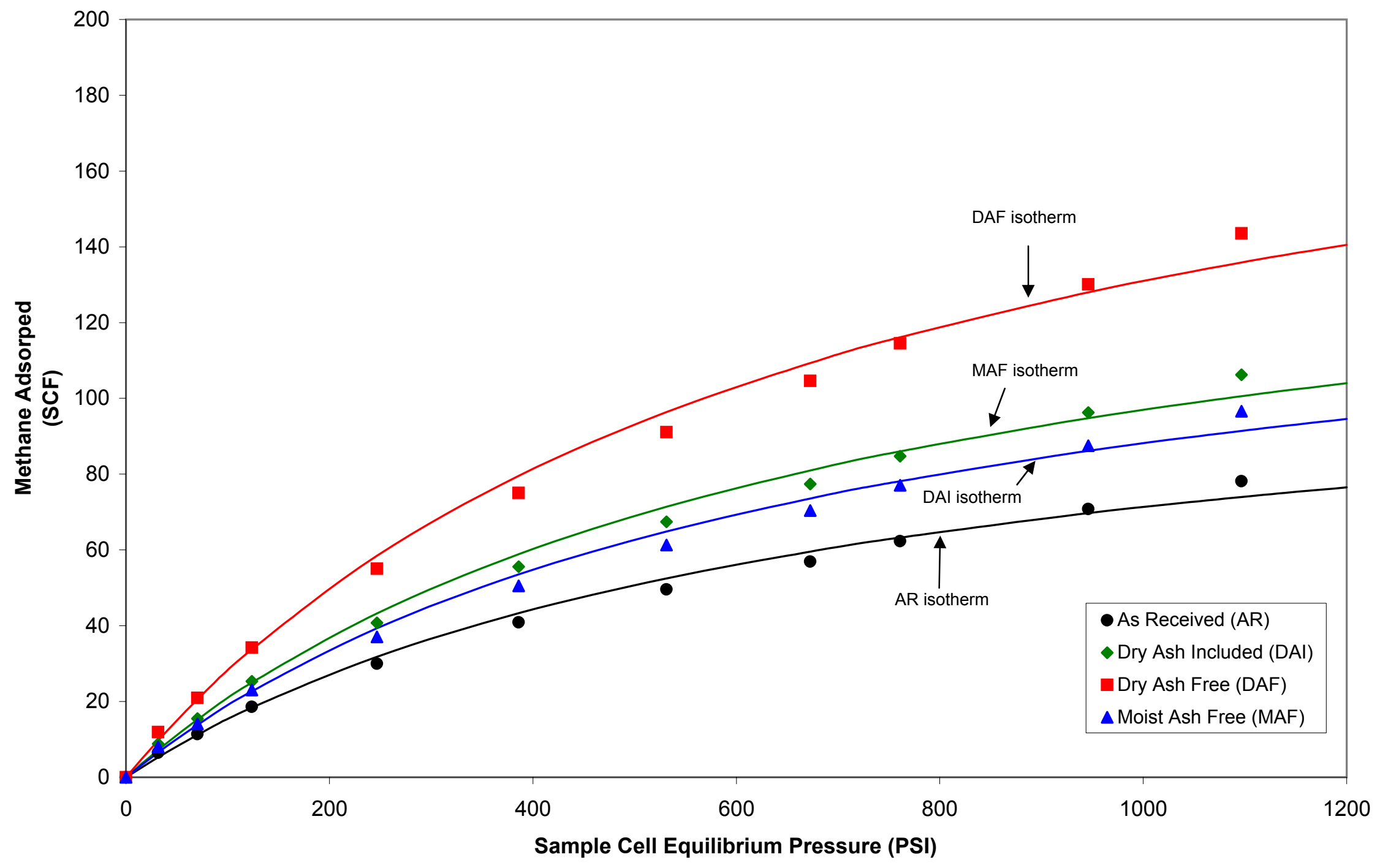




\section{AS RECEIVED BASIS}

PRESSURE (PSI)
32
70
124
247
386
531
673
761
946
1097

ADSORPED METHANE (SCF/ton)

\section{DRY ASH FREE BASIS}

PRESSURE (PSI)

70

124

247

386

531

673

761

946 1097

PRESSURE (PSI)

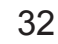

70

124

247

386

531

673

761

946

1097

\section{ADSORPED METHANE (SCF/ton)}

11.9
20.9
34.2
55.0
75.1
91.1
104.6
114.5
130.1
143.5

Saturated Monolayer Volume (SCF/ton, daf):

Langmuir Pressure (PSI):

\section{DRY ASH INCLUDED BASIS}

$\begin{array}{cc}\text { ADSORPED METHANE (SCF/ton) } & \mathbf{P} / \mathbf{V} \\ 8.8 & 3.58 \\ 15.5 & 4.53 \\ 25.3 & 4.89 \\ 40.7 & 6.06 \\ 55.6 & 6.95 \\ 67.4 & 7.88 \\ 77.4 & 8.69 \\ 84.8 & 8.98 \\ 96.3 & 9.82 \\ 106.2 & 10.32\end{array}$

Saturated Monolayer Volume (SCF/ton, dai): Langmuir Pressure (PSI):

\section{MOIST ASH FREE BASIS}

\section{PRESSURE (PSI)}

32

70

124

247

386

531

673

761

946

1097
ADSORPED METHANE (SCF/ton)

8.0

14.1

23.0

37.0

50.5

61.3

70.4

77.0

87.5

96.6 
USGS-PA-2-CN16

Methane Adsorption Isotherms

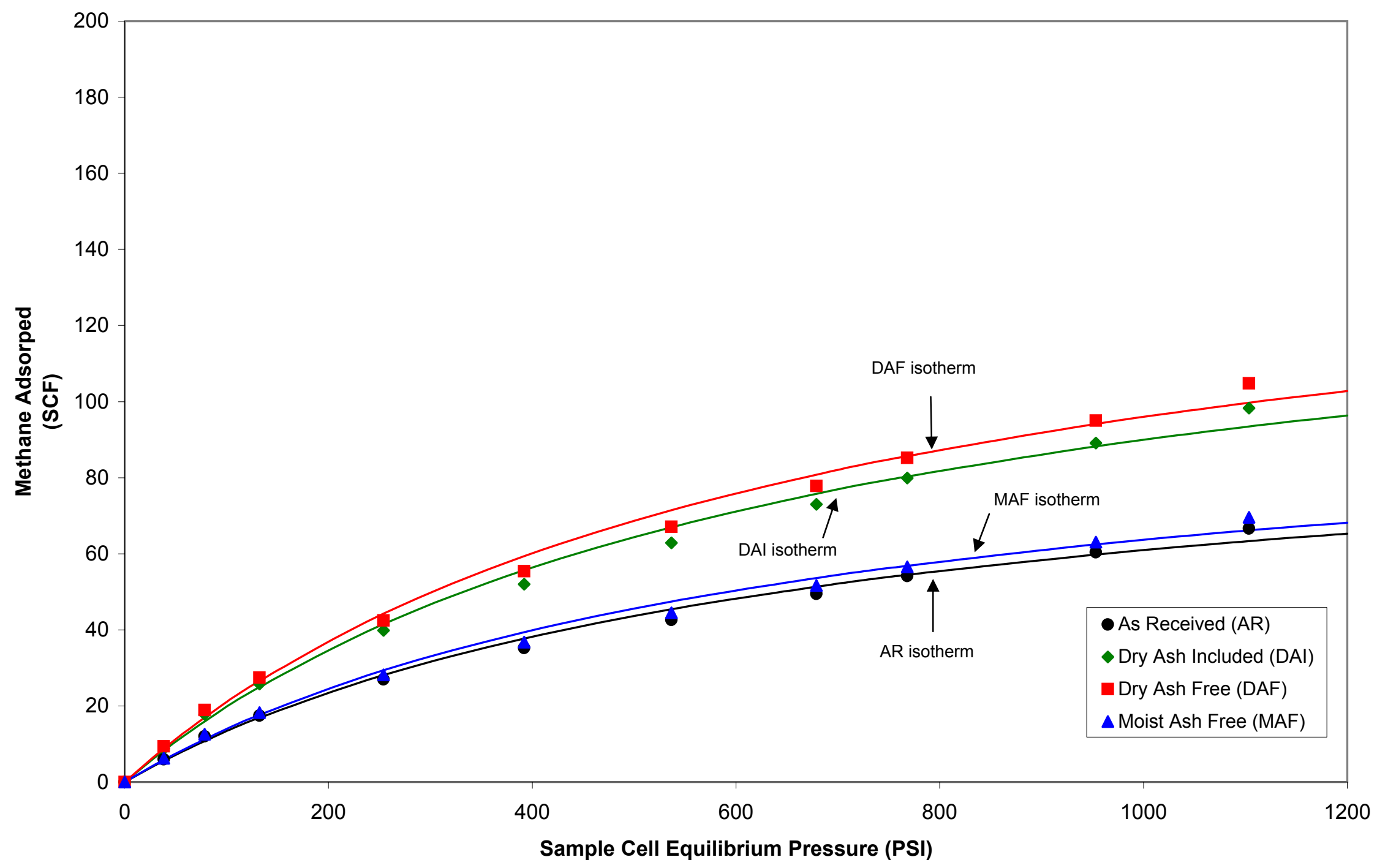


USGS-PA-2-CN16

METHANE ADSORPTION ISOTHERM CFG UNITS

Sample I.D. :

USGS-PA-2-CN16

Moisture Content (EQ) \% : $\quad 32.22$

Isotherm Temperature ${ }^{\circ} \mathrm{F}: \quad 86$

Correlation Coefficient: $\quad 0.98$

Dry Ash Content, \% :

Helium Density g/cc

AS RECEIVED BASIS

$\begin{array}{ccc}\text { PRESSURE (PSI) } & \text { ADSORPED METHANE (SCF/ton) } & \mathbf{P} / \mathbf{V} \\ 38 & 5.9 & 6.46 \\ 78 & 12.0 & 6.52 \\ 132 & 17.5 & 7.58 \\ 254 & 27.0 & 9.41 \\ 392 & 35.2 & 11.13 \\ 537 & 42.6 & 12.59 \\ 679 & 49.5 & 13.73 \\ 768 & 54.2 & 14.19 \\ 953 & 60.4 & 15.79 \\ 1103 & 66.6 & 16.57\end{array}$

Saturated Monolayer Volume (SCF/ton, as-received):

Langmuir Pressure (PSI):

DRY ASH FREE BASIS

PRESSURE (PSI)
38
78
132
254
392
537
679
768
953
1103

$\begin{array}{cc}\text { ADSORPED METHANE (SCF/ton) } & \mathbf{P} / \mathbf{V} \\ 9.4 & 4.11 \\ 18.9 & 4.14 \\ 27.5 & 4.82 \\ 42.5 & 5.98 \\ 55.4 & 7.07 \\ 67.1 & 8.00 \\ 77.8 & 8.72 \\ 85.2 & 9.01 \\ 95.0 & 10.03 \\ 104.8 & 10.53\end{array}$

Saturated Monolayer Volume (SCF/ton, daf):

DRY ASH INCLUDED BASIS

PRESSURE (PSI)
38
78
132
254
392
537
679
768
953
1103

$\begin{array}{cc}\text { ADSORPED METHANE (SCF/ton) } & \mathbf{P} / \mathbf{V} \\ 8.8 & 4.38 \\ 17.8 & 4.42 \\ 25.8 & 5.14 \\ 39.8 & 6.38 \\ 52.0 & 7.54 \\ 62.9 & 8.53 \\ 73.0 & 9.30 \\ 79.9 & 9.62 \\ 89.1 & 10.70 \\ 98.3 & 11.23\end{array}$

Saturated Monolayer Volume (SCF/ton, dai): Langmuir Pressure (PSI):

\section{MOIST ASH FREE BASIS}

PRESSURE (PSI)
38
78
132
254
392
537
679
768
953
1103

$\begin{array}{cc}\text { ADSORPED METHANE (SCF/ton) } & \mathbf{P} / \mathbf{V} \\ 6.2 & 6.19 \\ 12.6 & 6.24 \\ 18.2 & 7.26 \\ 28.2 & 9.01 \\ 36.8 & 10.66 \\ 44.5 & 12.05 \\ 51.6 & 13.14 \\ 56.5 & 13.58 \\ 63.0 & 15.12 \\ 69.6 & 15.87\end{array}$

Saturated Monolayer Volume (SCF/ton, maf): 


\section{Appendix 3}

\section{Carbon dioxide adsorption isotherms for sample USGS-PA-2-CN2}

Appendix 3 of

Results of coalbed methane drilling in Panola County, Texas

Edited By Peter D. Warwick', John R. SanFilipo', Alex W. Karlsen', and Charles E. Barker ${ }^{2}$

'U.S. Geological Survey, Reston, VA

${ }^{2}$ U.S. Geological Survey, Denver, CO

Open-File Report 2005-1046

U.S. Department of the Interior

U.S. Geological Survey 
USGS-PA-2-CN2

Carbon Dioxide Adsorption Isotherms

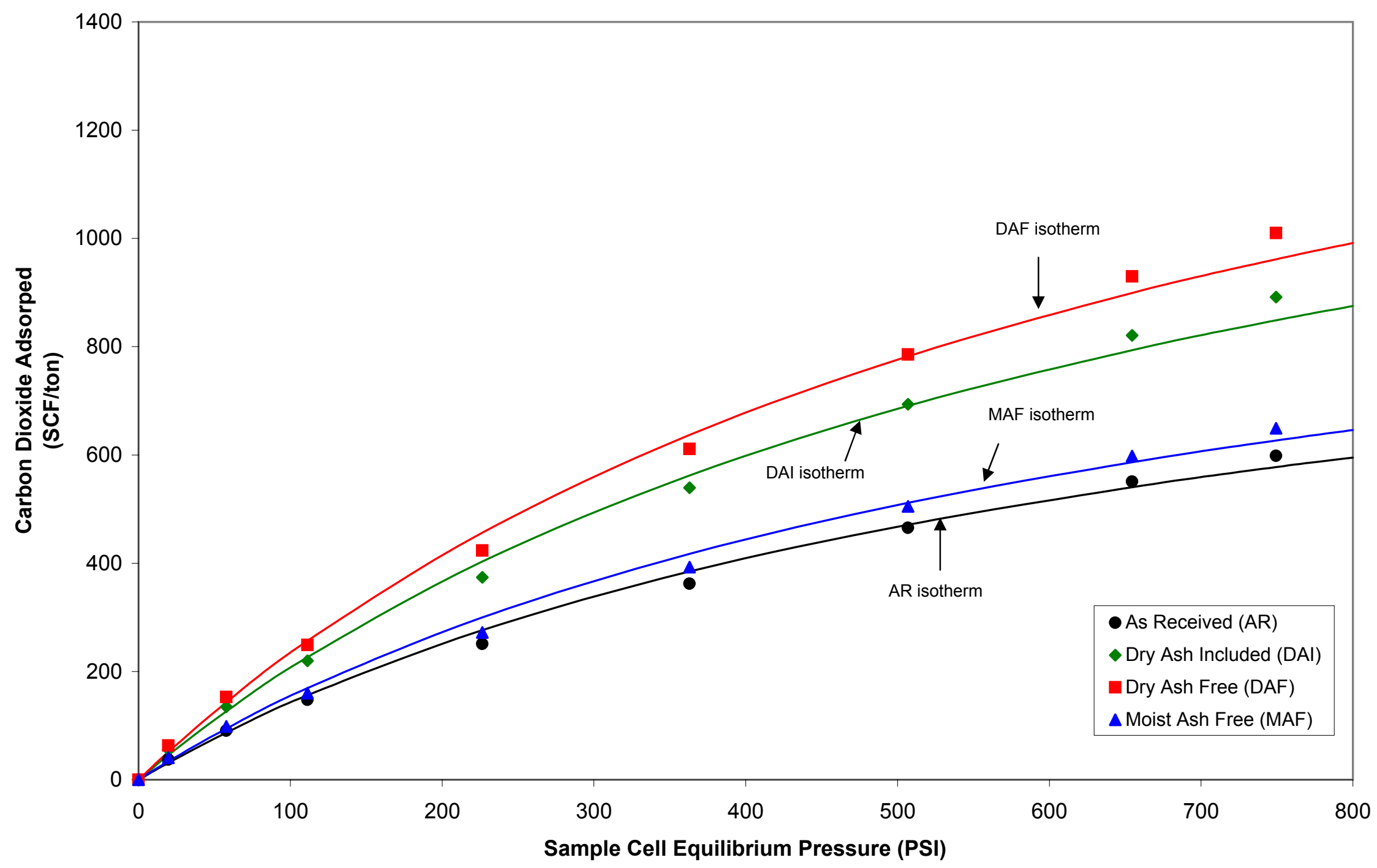


USGS-PA-2-CN2

CARBON DIOXIDE ADSORPTION ISOTHERM IMPERIAL UNITS

Sample I.D. :

USGS-PA-2-CN2

Moisture Content (EQ) \%

Isotherm Temperature ${ }^{\circ} \mathrm{F}: \quad 86$

Dry Ash Content \% :

Correlation Coefficient: 0.95

AS RECEIVED BASIS

PRESSURE (PSI)
20
58
111
226
363
507
655
749

$\begin{array}{cc}\text { ADSORPED CARBON DIOXIDE (SCF/ton) } & \mathbf{P} / \mathbf{V} \\ 37.4 & 0.53 \\ 90.6 & 0.64 \\ 147.4 & 0.75 \\ 250.7 & 0.90 \\ 361.9 & 1.00 \\ 465.4 & 1.09 \\ 550.7 & 1.19 \\ 598.2 & 1.25\end{array}$

Saturated Monolayer Volume (SCF/ton, as-received):

DRY ASH FREE BASIS

PRESSURE (PSI)
20
58
111
226
363
507
655
749

ADSORPED CARBON DIOXIDE (SCF/ton)
63.2
153.0
248.9
423.4
611.1
785.8
929.8
1010.2

Saturated Monolayer Volume (SCF/ton, daf):

\section{DRY ASH INCLUDED BASIS}

PRESSURE (PSI)
20
58
111
226
363
507
655
749

$\begin{array}{cc}\text { ADSORPED CARBON DIOXIDE (SCF/ton) } & \mathbf{P} / \mathbf{V} \\ 55.8 & 0.35 \\ 135.0 & 0.43 \\ 219.7 & 0.51 \\ 373.7 & 0.61 \\ 539.4 & 0.67 \\ 693.6 & 0.73 \\ 820.8 & 0.80 \\ 891.7 & 0.84\end{array}$

Saturated Monolayer Volume (SCF/ton, dai):

MOIST ASH FREE BASIS

PRESSURE (PSI)
20
58
111
226
363
507
655
749

$\begin{array}{cc}\text { ADSORPED CARBON DIOXIDE (SCF/ton) } & \mathbf{P} / \mathbf{V} \\ 40.6 & 0.48 \\ 98.3 & 0.59 \\ 160.0 & 0.70 \\ 272.1 & 0.83 \\ 392.8 & 0.92 \\ 505.1 & 1.00 \\ 597.7 & 1.10 \\ 649.3 & 1.15\end{array}$

Saturated Monolayer Volume (SCF/ton, mai): 


\section{Appendix 4}

\section{Extended Langmuir modeling data for sample USGS-PA-2-CN2}

Appendix 4 of

Results of coalbed methane drilling in Panola County, Texas

Edited By Peter D. Warwick', John R. SanFilipo ${ }^{1}$, Alex W. Karlsen', and Charles E. Barker ${ }^{2}$

'U.S. Geological Survey, Reston, VA

${ }^{2}$ U.S. Geological Survey, Denver, CO

Open-File Report 2005-1046

U.S. Department of the Interior

U.S. Geological Survey 
Extended Langmuir Model (80\% CH4, 20\% CO2)

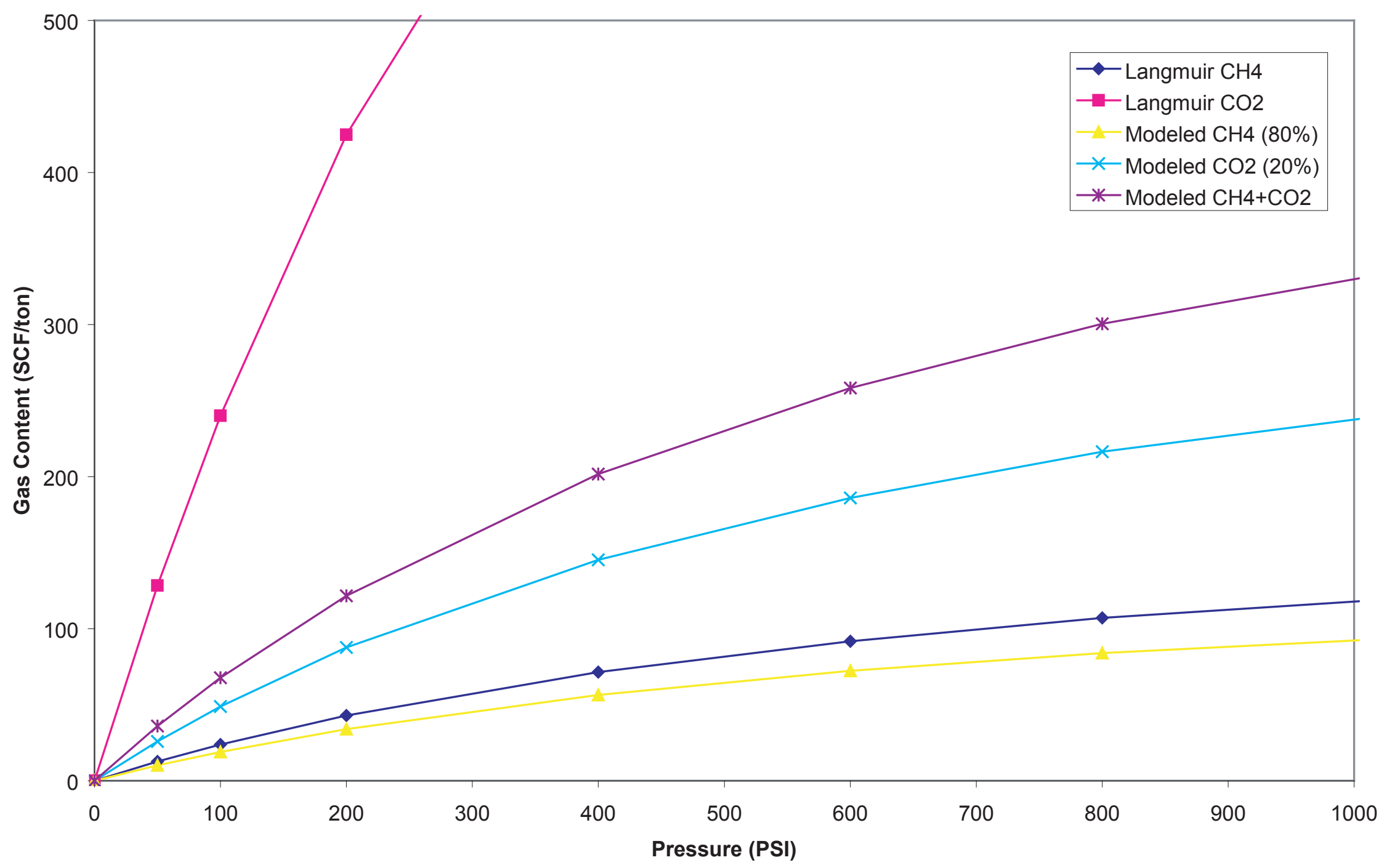


USGS-PA-2-CN2

EXTENDED LANGMUIR MODEL (80\% CH4 AND 20\% CO2) DRY ASH FREE BASIS (SCF/TON)

\begin{tabular}{cccccc}
$\begin{array}{c}\text { Pressure } \\
\text { PSI }\end{array}$ & $\begin{array}{c}\text { Langmuir } \\
\text { CH4 }\end{array}$ & $\begin{array}{c}\text { Langmuir } \\
\text { CO2 }\end{array}$ & CH4 (80\%) & $\begin{array}{c}\text { Modeled } \\
\text { C02 (20\%) }\end{array}$ & CH4 +CO2 \\
0 & 0 & 0 & 0 & 0 & 0 \\
50 & 13 & 128 & 10 & 26 & 36 \\
100 & 24 & 240 & 19 & 49 & 68 \\
200 & 43 & 425 & 34 & 88 & 122 \\
400 & 71 & 691 & 56 & 145 & 202 \\
600 & 92 & 873 & 72 & 186 & 258 \\
800 & 107 & 1005 & 84 & 216 & 300 \\
1200 & 128 & 1185 & 100 & 259 & 359 \\
1600 & 143 & 1301 & 111 & 287 & 398 \\
\hline & & & & & \\
Langmuir Volume & 214.026 & 1844.985 & 165 & 424 & 589 \\
(SCF/ton) & & & 769 & 769 &
\end{tabular}


Extended Langmuir Model (85\% CH4, 15\% CO2)

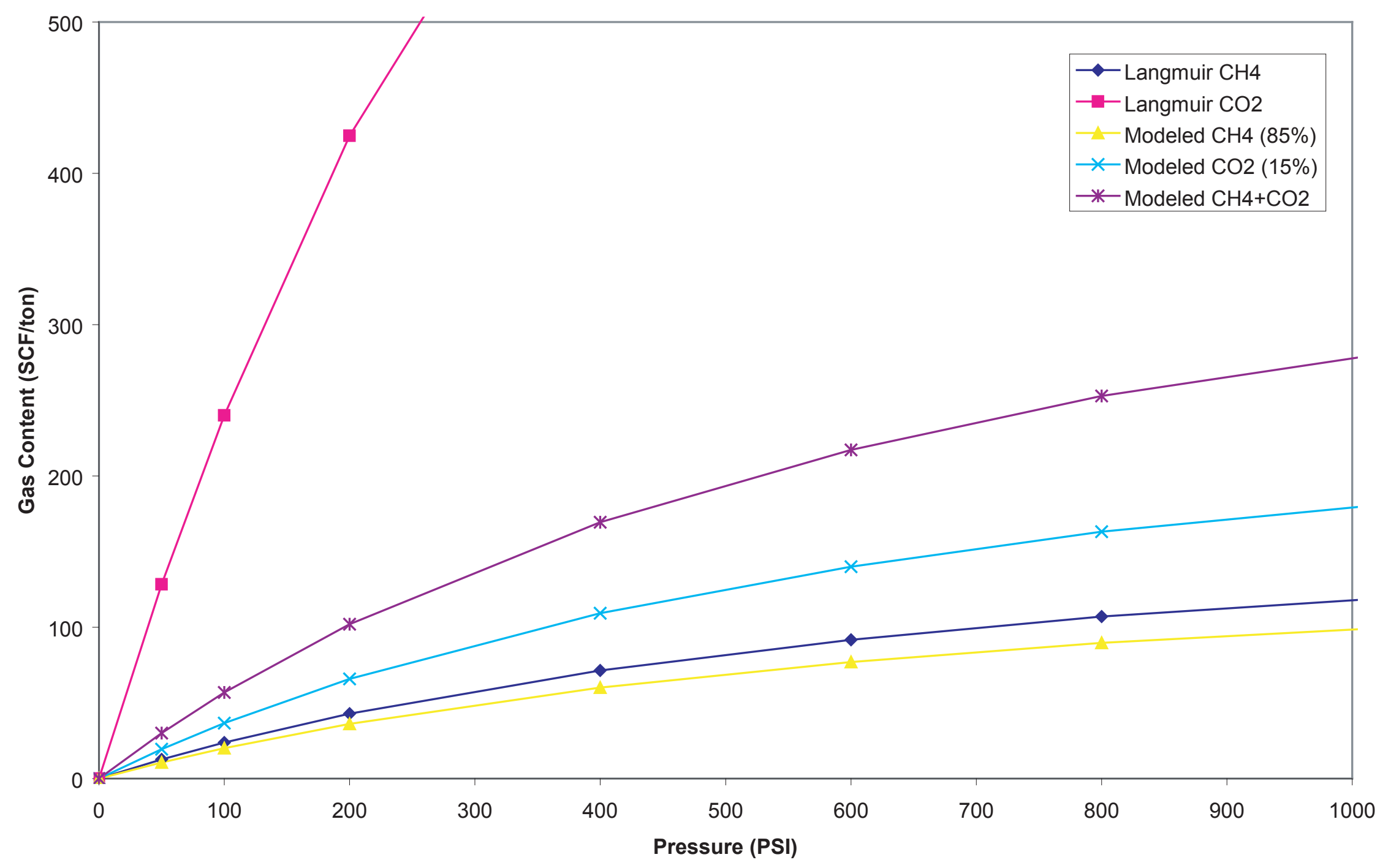




\section{USGS-PA-2-CN2}

EXTENDED LANGMUIR MODEL (85\% CH4 AND 15\% CO2) DRY ASH FREE BASIS (SCF/TON)

\begin{tabular}{|c|c|c|c|c|c|}
\hline $\begin{array}{c}\text { Pressure } \\
\text { PSI }\end{array}$ & $\begin{array}{c}\text { Langmuir } \\
\mathrm{CH} 4\end{array}$ & $\begin{array}{l}\text { Langmuir } \\
\text { CO2 }\end{array}$ & CH4 (85\%) & $\begin{array}{l}\text { Modeled } \\
\text { C02 (15\%) }\end{array}$ & $\mathrm{CH} 4+\mathrm{CO} 2$ \\
\hline 0 & 0 & 0 & 0 & 0 & 0 \\
\hline 50 & 13 & 128 & 11 & 19 & 30 \\
\hline 100 & 24 & 240 & 20 & 37 & 57 \\
\hline 200 & 43 & 425 & 36 & 66 & 102 \\
\hline 400 & 71 & 691 & 60 & 109 & 169 \\
\hline 600 & 92 & 873 & 77 & 140 & 217 \\
\hline 800 & 107 & 1005 & 90 & 163 & 253 \\
\hline 1200 & 128 & 1185 & 107 & 195 & 302 \\
\hline 1600 & 143 & 1301 & 119 & 216 & 335 \\
\hline $\begin{array}{l}\text { Langmuir Volume } \\
\text { (SCF/ton) }\end{array}$ & 214.026 & 1844.985 & 177 & 321 & 498 \\
\hline $\begin{array}{l}\text { Langmuir Pressure } \\
\text { (PSI) }\end{array}$ & 798.925 & 668.481 & 776 & 776 & 776 \\
\hline
\end{tabular}


Extended Langmuir Model ( $90 \% \mathrm{CH} 4,10 \% \mathrm{CO} 2)$

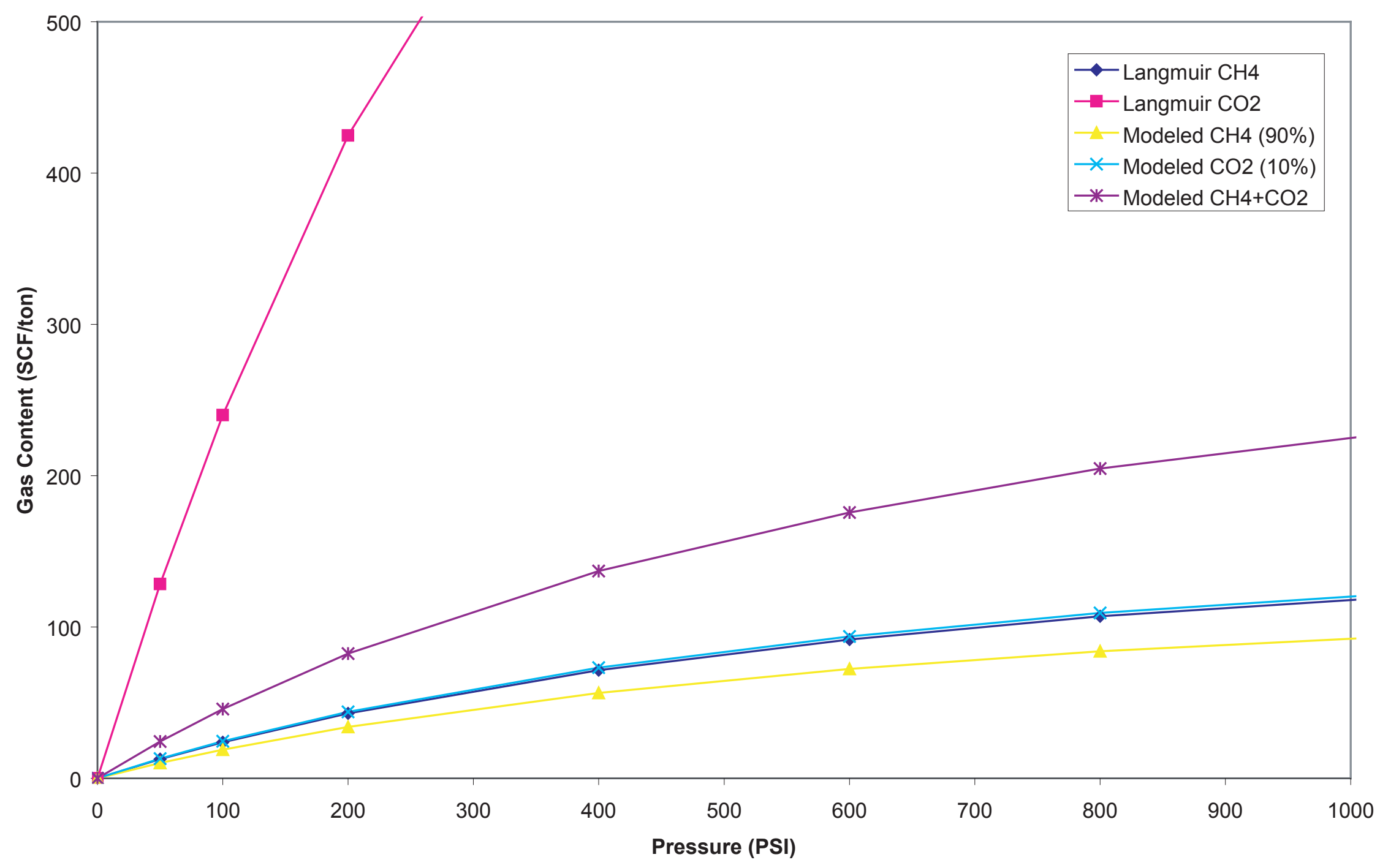


USGS-PA-2-CN2

EXTENDED LANGMUIR MODEL ( $90 \%$ CH4 AND 10\% CO2) DRY ASH FREE BASIS (SCF/TON)

\begin{tabular}{|c|c|c|c|c|c|}
\hline $\begin{array}{l}\text { Pressure } \\
\text { PSI }\end{array}$ & $\begin{array}{l}\text { Langmuir } \\
\text { CH4 }\end{array}$ & $\begin{array}{l}\text { Langmuir } \\
\text { CO2 }\end{array}$ & CH4 (90\%) & $\begin{array}{l}\text { Modeled } \\
\text { C02 }(10 \%)\end{array}$ & $\mathrm{CH} 4+\mathrm{CO} 2$ \\
\hline 0 & 0 & 0 & 0 & 0 & 0 \\
\hline 50 & 13 & 128 & 11 & 13 & 24 \\
\hline 100 & 24 & 240 & 21 & 24 & 46 \\
\hline 200 & 43 & 425 & 38 & 44 & 82 \\
\hline 400 & 71 & 691 & 64 & 73 & 137 \\
\hline 600 & 92 & 873 & 82 & 94 & 176 \\
\hline 800 & 107 & 1005 & 95 & 109 & 205 \\
\hline 1200 & 128 & 1185 & 114 & 131 & 245 \\
\hline 1600 & 143 & 1301 & 127 & 145 & 272 \\
\hline $\begin{array}{l}\text { Langmuir Volume } \\
\text { (SCF/ton) }\end{array}$ & 214.026 & 1844.985 & 189 & 216 & 405 \\
\hline $\begin{array}{l}\text { Langmuir Pressure } \\
\text { (PSI) }\end{array}$ & 798.925 & 668.481 & 784 & 784 & 784 \\
\hline
\end{tabular}


Extended Langmuir Model $(93 \% \mathrm{CH} 4,7 \% \mathrm{CO} 2)$

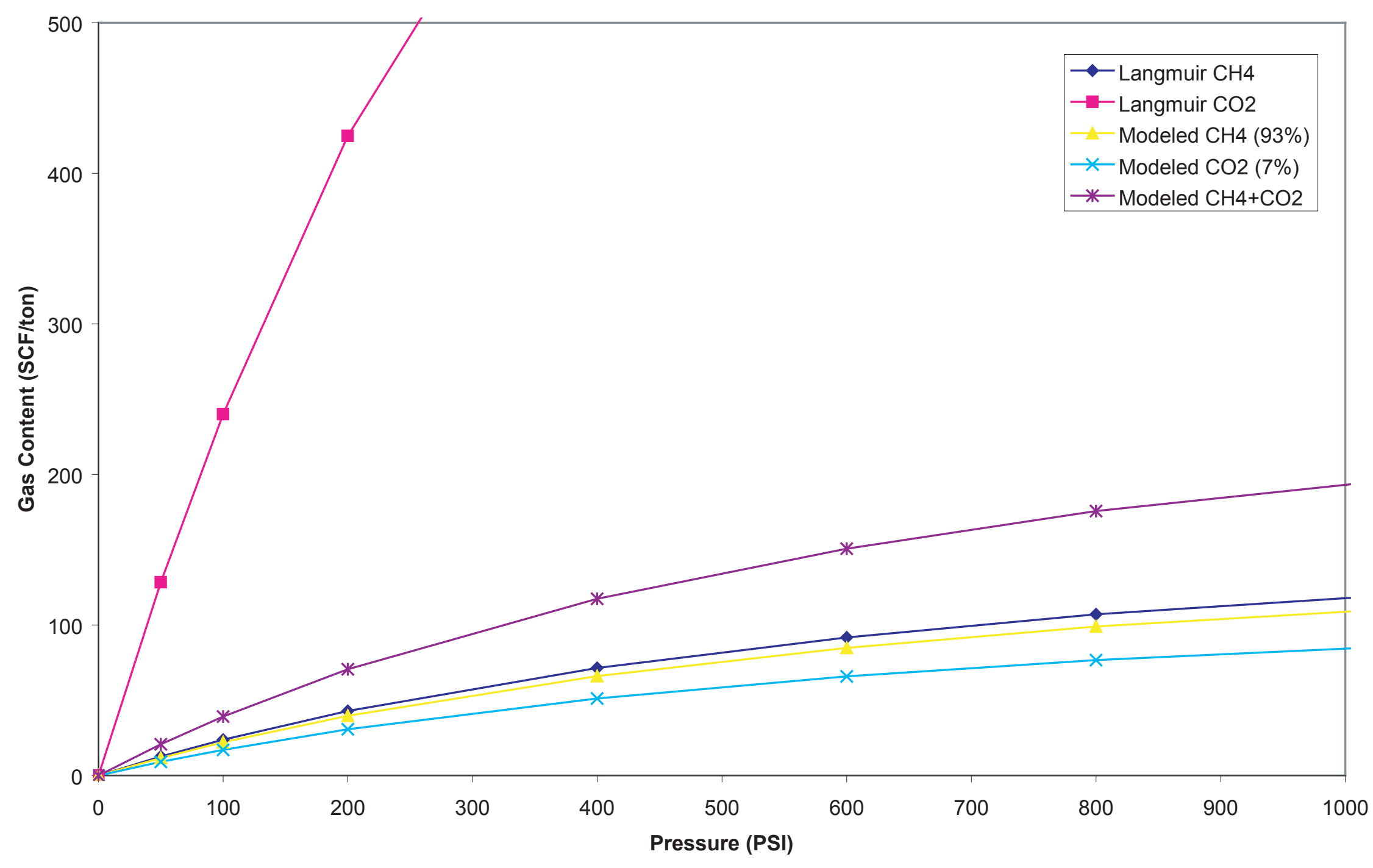


USGS-PA-2-CN2

EXTENDED LANGMUIR MODEL (93\% CH4 AND 7\% CO2) DRY ASH FREE BASIS (SCF/TON)

\begin{tabular}{|c|c|c|c|c|c|}
\hline $\begin{array}{l}\text { Pressure } \\
\text { PSI }\end{array}$ & $\begin{array}{l}\text { Langmuir } \\
\text { CH4 }\end{array}$ & $\begin{array}{l}\text { Langmuir } \\
\text { CO2 }\end{array}$ & CH4 (93\%) & $\begin{array}{l}\text { Modeled } \\
\text { C02 (7\%) }\end{array}$ & $\mathrm{CH} 4+\mathrm{CO} 2$ \\
\hline 0 & 0 & 0 & 0 & 0 & 0 \\
\hline 50 & 13 & 128 & 12 & 9 & 21 \\
\hline 100 & 24 & 240 & 22 & 17 & 39 \\
\hline 200 & 43 & 425 & 40 & 31 & 71 \\
\hline 400 & 71 & 691 & 66 & 51 & 117 \\
\hline 600 & 92 & 873 & 85 & 66 & 151 \\
\hline 800 & 107 & 1005 & 99 & 77 & 176 \\
\hline 1200 & 128 & 1185 & 119 & 92 & 210 \\
\hline 1600 & 143 & 1301 & 132 & 102 & 234 \\
\hline $\begin{array}{l}\text { Langmuir Volume } \\
\text { (SCF/ton) }\end{array}$ & 214.026 & 1844.985 & 196 & 152 & 349 \\
\hline $\begin{array}{l}\text { Langmuir Pressure } \\
\text { (PSI) }\end{array}$ & 798.925 & 668.481 & 788 & 788 & 788 \\
\hline
\end{tabular}


Extended Langmuir Model (95\% CH4, 5\% CO2)

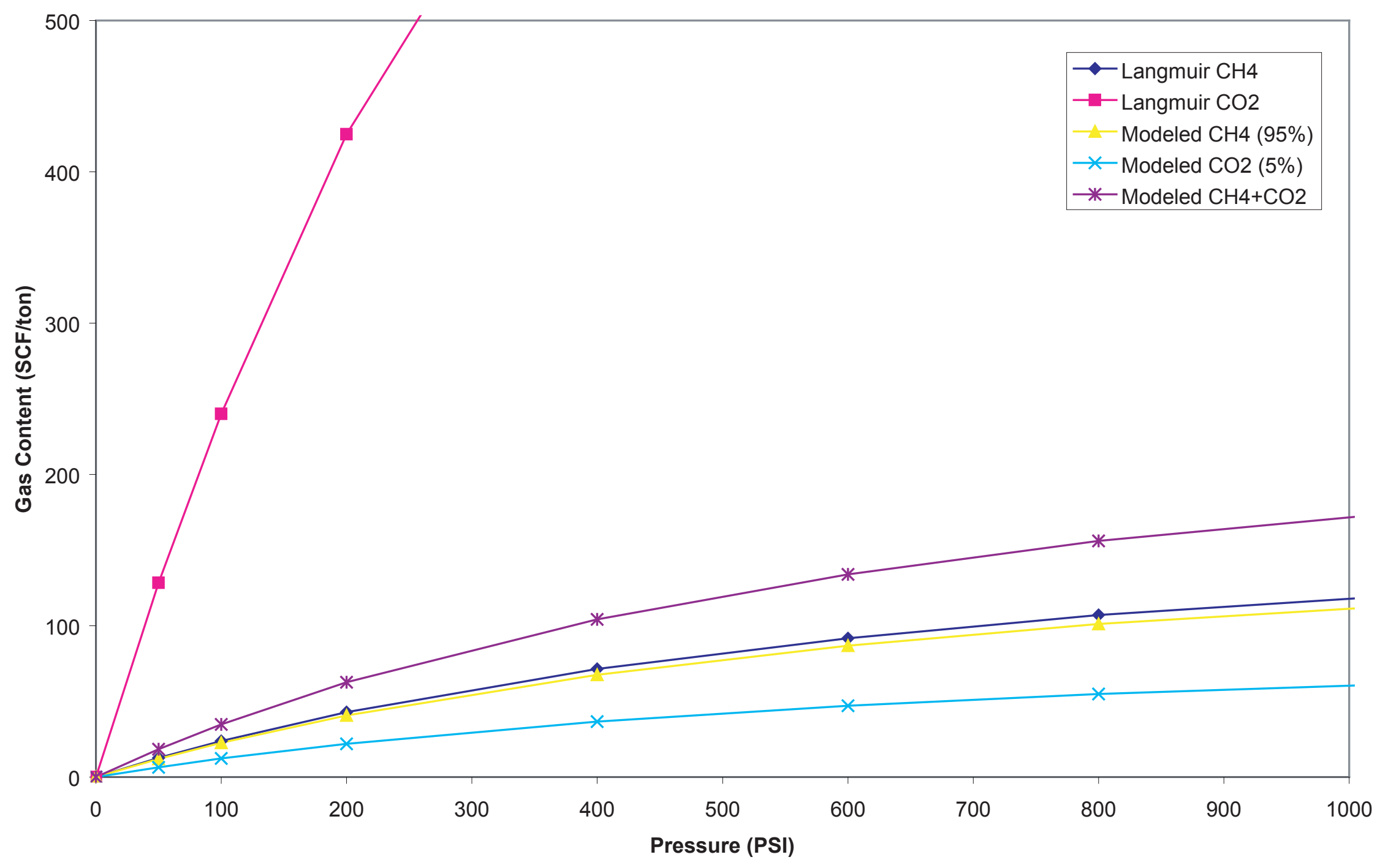


USGS-PA-2-CN2

EXTENDED LANGMUIR MODEL (95\% CH4 AND 5\% CO2) DRY ASH FREE BASIS (SCF/TON)

\begin{tabular}{|c|c|c|c|c|c|}
\hline $\begin{array}{l}\text { Pressure } \\
\text { PSI }\end{array}$ & $\begin{array}{l}\text { Langmuir } \\
\mathrm{CH} 4\end{array}$ & $\begin{array}{l}\text { Langmuir } \\
\text { CO2 }\end{array}$ & CH4 (95\%) & $\begin{array}{l}\text { Modeled } \\
\text { C02 (5\%) }\end{array}$ & $\mathrm{CH} 4+\mathrm{CO} 2$ \\
\hline 0 & 0 & 0 & 0 & 0 & 0 \\
\hline 50 & 13 & 128 & 12 & 6 & 18 \\
\hline 100 & 24 & 240 & 23 & 12 & 35 \\
\hline 200 & 43 & 425 & 41 & 22 & 63 \\
\hline 400 & 71 & 691 & 68 & 37 & 104 \\
\hline 600 & 92 & 873 & 87 & 47 & 134 \\
\hline 800 & 107 & 1005 & 101 & 55 & 156 \\
\hline 1200 & 128 & 1185 & 121 & 66 & 187 \\
\hline 1600 & 143 & 1301 & 135 & 73 & 208 \\
\hline $\begin{array}{l}\text { Langmuir Volume } \\
\text { (SCF/ton) }\end{array}$ & 214.026 & 1844.985 & 201 & 109 & 311 \\
\hline $\begin{array}{l}\text { Langmuir Pressure } \\
\text { (PSI) }\end{array}$ & 798.925 & 668.481 & 791 & 791 & 791 \\
\hline
\end{tabular}


Extended Langmuir Model $(97 \% \mathrm{CH} 4,3 \% \mathrm{CO} 2)$

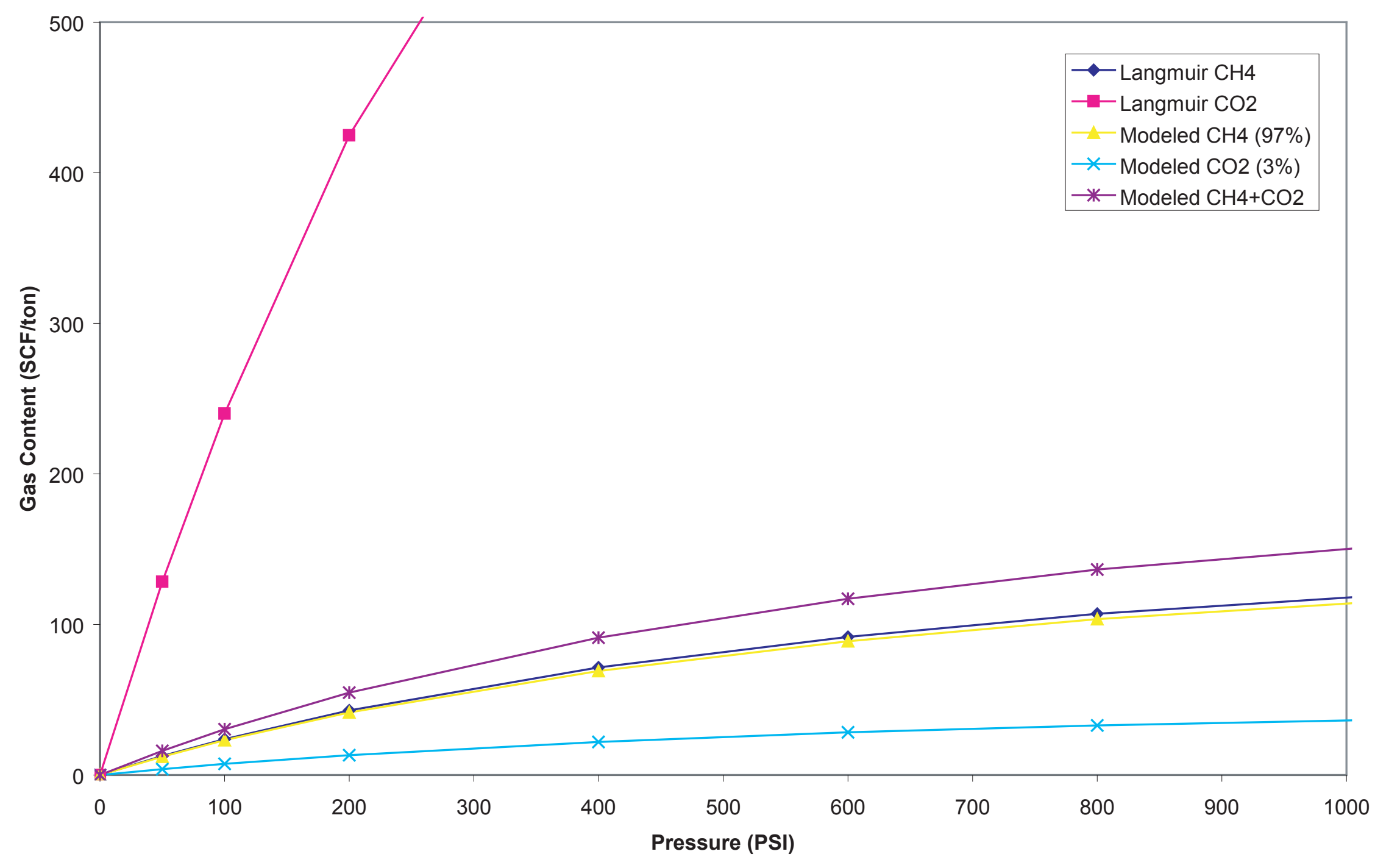


USGS-PA-2-CN2

EXTENDED LANGMUIR MODEL (97\% CH4 AND 3\% CO2) DRY ASH FREE BASIS (SCF/TON)

\begin{tabular}{|c|c|c|c|c|c|}
\hline $\begin{array}{l}\text { Pressure } \\
\text { PSI }\end{array}$ & $\begin{array}{l}\text { Langmuir } \\
\text { CH4 }\end{array}$ & $\begin{array}{l}\text { Langmuir } \\
\text { CO2 }\end{array}$ & CH4 (97\%) & $\begin{array}{l}\text { Modeled } \\
\text { C02 (3\%) }\end{array}$ & $\mathrm{CH} 4+\mathrm{CO} 2$ \\
\hline 0 & 0 & 0 & 0 & 0 & 0 \\
\hline 50 & 13 & 128 & 12 & 4 & 16 \\
\hline 100 & 24 & 240 & 23 & 7 & 30 \\
\hline 200 & 43 & 425 & 42 & 13 & 55 \\
\hline 400 & 71 & 691 & 69 & 22 & 91 \\
\hline 600 & 92 & 873 & 89 & 28 & 117 \\
\hline 800 & 107 & 1005 & 104 & 33 & 137 \\
\hline 1200 & 128 & 1185 & 124 & 40 & 164 \\
\hline 1600 & 143 & 1301 & 138 & 44 & 182 \\
\hline $\begin{array}{l}\text { Langmuir Volume } \\
\text { (SCF/ton) }\end{array}$ & 214.026 & 1844.985 & 206 & 66 & 272 \\
\hline $\begin{array}{l}\text { Langmuir Pressure } \\
\text { (PSI) }\end{array}$ & 798.925 & 668.481 & 794 & 794 & 794 \\
\hline
\end{tabular}




\section{Appendix 5}

\section{Gas analysis of sample USGS-PA-2-CN13}

Appendix 5 of

Results of coalbed methane drilling in Panola County, Texas

Edited By Peter D. Warwick', John R. SanFilipo', Alex W. Karlsen', and Charles E. Barker ${ }^{2}$

'U.S. Geological Survey, Reston, VA

U.S. Geological Survey, Denver, CO

Open-File Report 2005-1046

U.S. Department of the Interior

U.S. Geological Survey 


\section{ANALYSIS REPORT}

Lab \#:

Sample Name/Number:

Company:

Date Sampled:

Container:

Field/Site Name:

Location:

Formation/Depth:

Sampling Point:

Date Received:

Component

Carbon Monoxide --.-.-.-...

Helium

Hydrogen

Argon

Oxygen

Nitrogen

Carbon Dioxide

Methane

Ethane

Ethylene

Propane

Iso-butane

$\mathrm{N}$-butane

Iso-pentane

$\mathrm{N}$-pentane

Hexanes +
21397

99-13 PA-2

U.S. Geological Survey, Denver CO

11

Cylinder

Wilcox CBM

Job \#: 1888

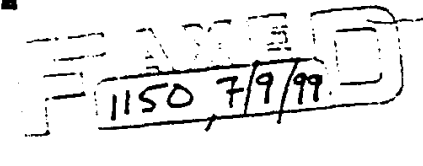

7/08/1999 Date Reported: 7/09/1999

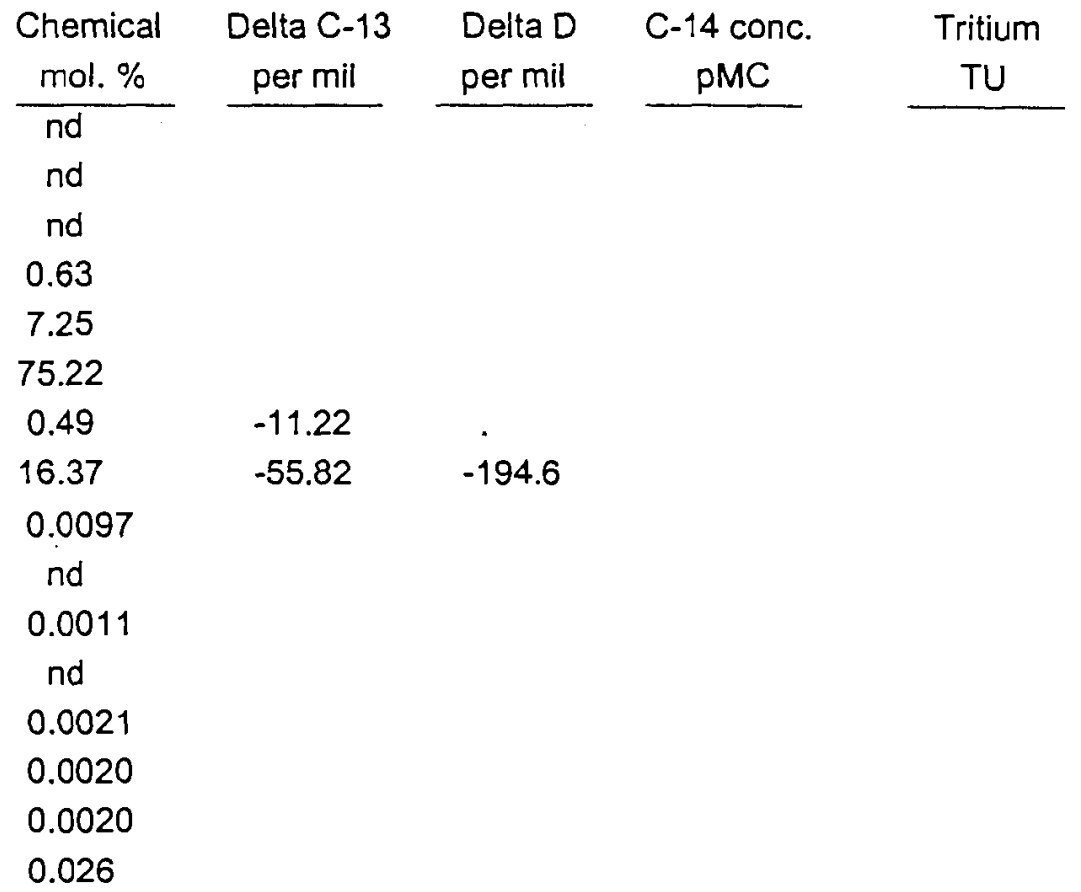

Total BTU/cu.ft. dry@60deg F \& 14.7psia, calculated: 167

Specific gravity, calculated: 0.916

$\mathrm{nd}=$ not detected. $\mathrm{na}=$ not analyzed. Isotopic composition of carbon is relative to VPDB. Isotopic composition of hydrogen is relative to VSMOW. Calcualtions for BTU and specific gravity per ASTM D3588. Chemical compositions are normalized to 100 percent. Mol. \% is approximately equal to vol. \% 


\section{Appendix 6}

\section{Drilling permit for boreholes USGS-PA-1 and USGS-PA-2}

Appendix 6 of

Results of coalbed methane drilling in Panola County, Texas

Edited By Peter D. Warwick', John R. SanFilipo', Alex W. Karlsen', and Charles E. Barker ${ }^{2}$

'U.S. Geological Survey, Reston, VA

${ }^{2}$ U.S. Geological Survey, Denver, CO

Open-File Report 2005-1046

U.S. Department of the Interior

U.S. Geological Survey 


\section{United States Department of the Interior}

\section{U.S. GEOLOGICAL SURVEY}

Reston, Virginia 20192

Pet Reply Refer To:

MS 956

June 4, 1999

Mr. Timothy G. Walter

Railroad Commission of Texas

Surface Mining and Reclamation Division

1701 N. Congress Avenue

P.O.B. 12967

Austin, TX 78711-2967

Dear Tim,

Please find enclosed three copies of a "Notice of Plan to Conduct Coal Exploration Activities," (Railroad Commission of Texas form SMRD-3C (04/97)). As indicated on the form, we plan to drill in Panola County starting about June 14, 1999. Thank you for sending us copies of the form. If you have any questions, please call me at (703) 648-6469.

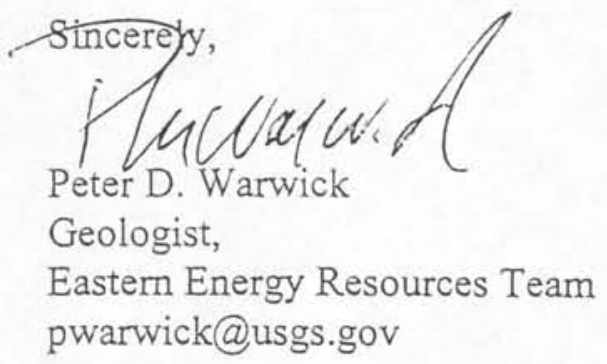

encl.

cc: EERS Chron file 


\section{RAILROAD COMMUSSION OF TEXAS \\ SURFACE MINING AND RECLAMATION DIVISION}

\section{NOTICE OF PLAN TO CONDUCT COAL EXPLORATION ACTIVITIES IN WHICH 250 TONS OR LESS WUL BE REMOVED}

All items should be addressed completely. File in triplicate with the Director of the Surface Mining and Reclamation Division.

I. Name of Registrant Peter D. Warwick

Mailing Address U.S. Geological Survey, MS 956

\begin{tabular}{cccc} 
& \multicolumn{3}{c}{ (Street or P.O. Box) } \\
Reston & Virginia & 20192 & $703-648-6469$ \\
\hline (City) & (State) & (Zip Code) & (Telephone)
\end{tabular}

II. Name of Operator Lloyd E. Morris, Texas A\&M University

Mailing Address Department of Geology \& Geophysics, 109 Halbouty Bldg

\begin{tabular}{llrl} 
& \multicolumn{3}{c}{ (Street or P.O. Box) } \\
College Station & Texas & $77843-3115$ & $409-845-0119$ \\
\hline (City) & (State) & (Zip Code) & (Telephone)
\end{tabular}

III. Required Information (16 Texas Admin. Code $\$ 12.110)$

A. Describe the basis upon which the registrant and operator claim the right to enter the exploration area for the purpose of conducting exploration and reclamation activities. This description should state the type(s) of exploration agreement (i.e., lease, letter, etc.) provided by the surface owner. This information may be withheld from public files if requested pursuant to $\$ 12.115$.

We have the surface owners written permission.

B. Exploration for: [ ] Coal $[X]$ Lignite

Amount to be removed: about 0.02 tons

C. Provide the geographic location, by description and map, showing the boundaries of the area, referred to in part III. A., in which the company intends to explore.

Panola County, TX, about 15 miles east of Carthage (Lat. 31 $58^{\circ} 55^{\prime \prime} \mathrm{N}$, Long. 94 $09^{\prime} 07^{\prime \prime} \mathrm{W}$ ) and about 15 miles southeast of Carthage (Lat. $32^{\circ} 07^{\prime} 58^{\prime \prime} \mathrm{N}$ Long. $94^{\circ} 03^{\prime} 06^{\prime \prime} \mathrm{W}$ ) 
Map scale must be $1: 24,000$ or larger. The name of the county(s) in which exploration activities are to occur should be provided in the description.

Seo arached 7.5' USGS miaps.

D. Describe the method of exploration to be used (i.e., drill holes, pits or trenches, etc.), and the equipment used.

Two $500 \mathrm{ft}$ drill holes are planned using a Mobile B-53 Drilling Rig.

E. Describe the extent of anticipated exploration, including the proposed depth of penetration and the estimated numberlof scres that will be disturbed by exploration activities.

Two $500 \mathrm{ft}$ drill holes are planned, portable mud pits will be used, and less than 0.125 acres will be disturbed at each site.

F. Indicate the approximate time period during which exploration activities will be performed. Permits are issued for a period of one (1) year, and are renewable by application to the Commission.

Drilling activities will také place from Jumo 12 to July 15,1999

IV. Reclamation (16 Texas Admin Code \$12.110)

A. Identify plans for reclamation activities, including backfilling, grading, and revegetation methods to bo used, and plans for disposal of any toxic or radioactive material.

The site will be cleaned after drilling is complete to remoye excess drilling mud; no backfilling or grading will; be necessary because we are using portable mud pits, no revegstation will be requitred. There will be no toxic or radioactive materials left at the site.

B. Describe plans necessary for the protection of surface and underground water in the exploration and adjacent affected aress.

The surface and undergroünd water in the surface and adjacent areas will not be affected. The holes will be plugged with "Fole Plug" and concrete plugs set $\frac{2}{2}$ below the ground surface.

Bentomite

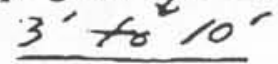

I, (name) Peter D.Warwick (title: Geologist) state that I have knowledge of the facts her ein set forth and that the same are true and correct to the best of my knowledige and belief. I further state that to the best of my lenowledge and belief, the project for which application is made will not in any way violate any law, rule, ordinance, or decree of any duly authorized govemmental entify having jurisdiction.

Date: $\quad f-4-99$ Sighature:

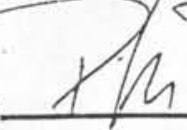
Sighature:

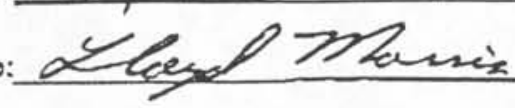

(Registrant)

Date:

$6-4-94$

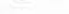

(Operator) 
USGS-PA-1

UTM 15N

$3,555,490 \mathrm{~m} \mathrm{~N}$

ตे

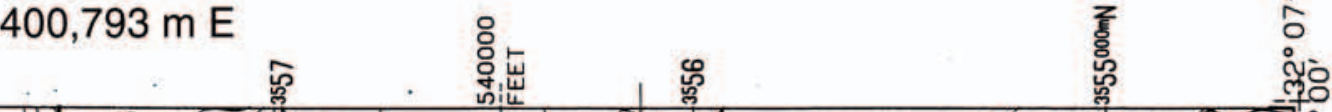

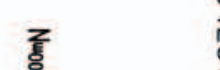

$400,793 \mathrm{~m} \mathrm{E}$.

1 के

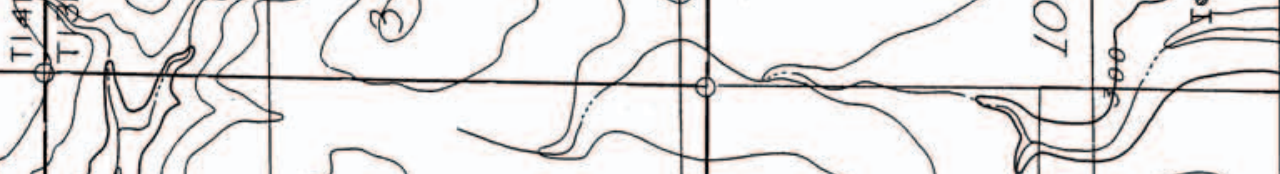
) 3$\}\{3$
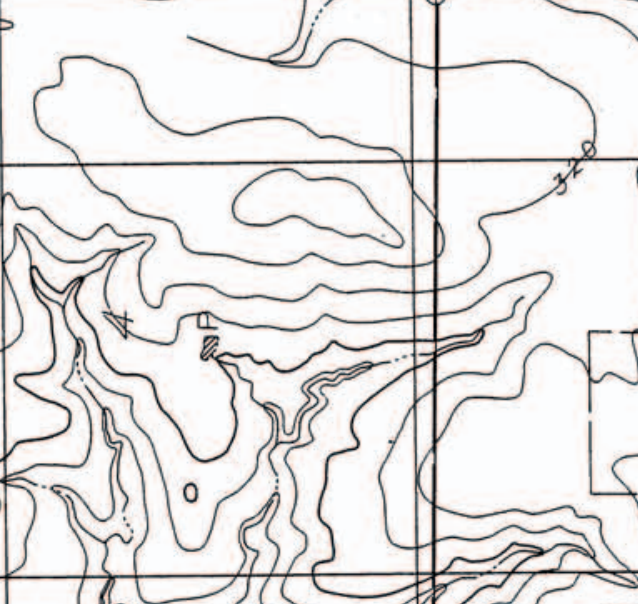

if

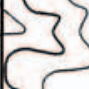

(a)

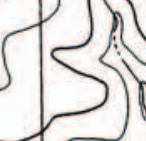

3
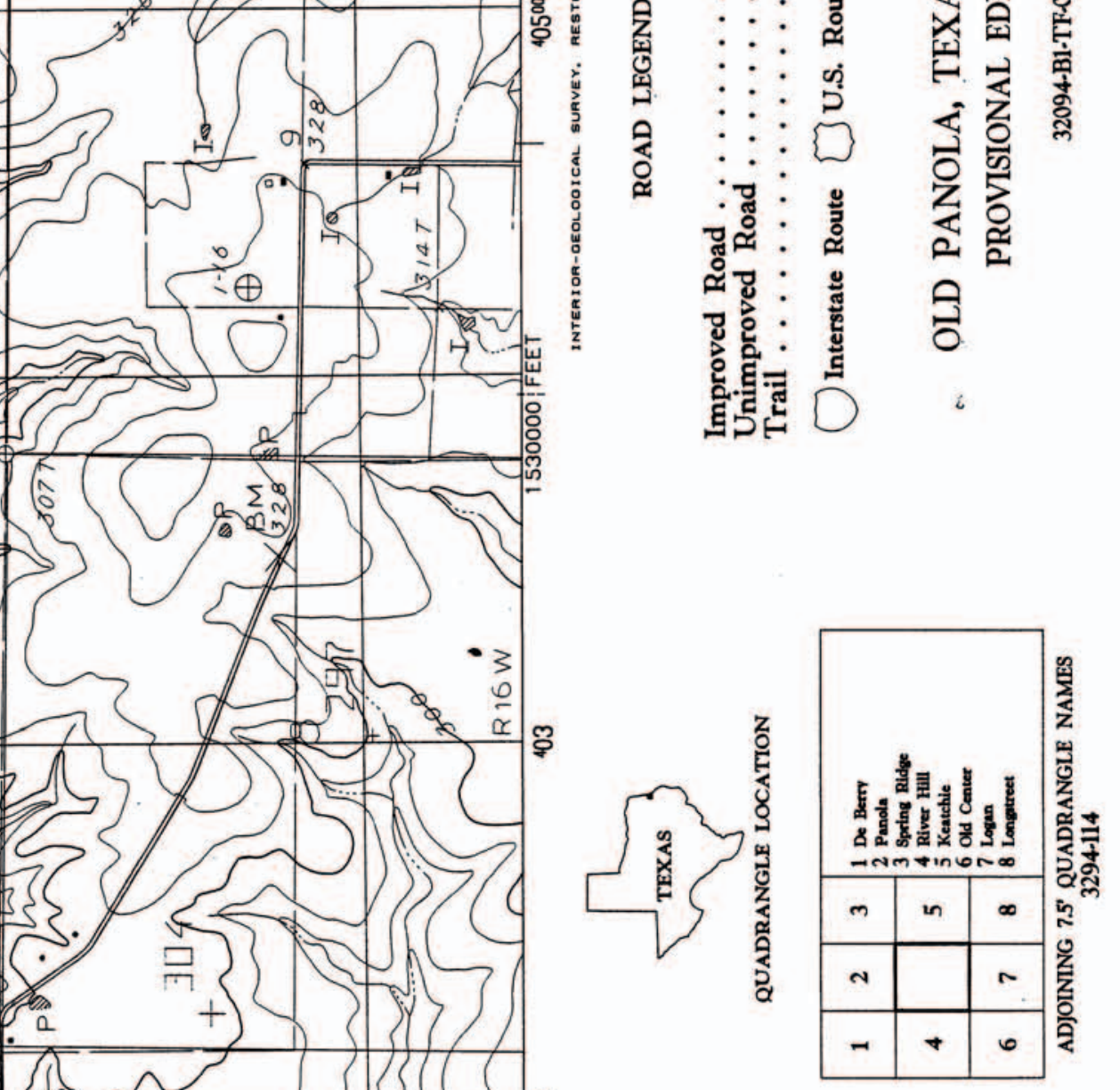

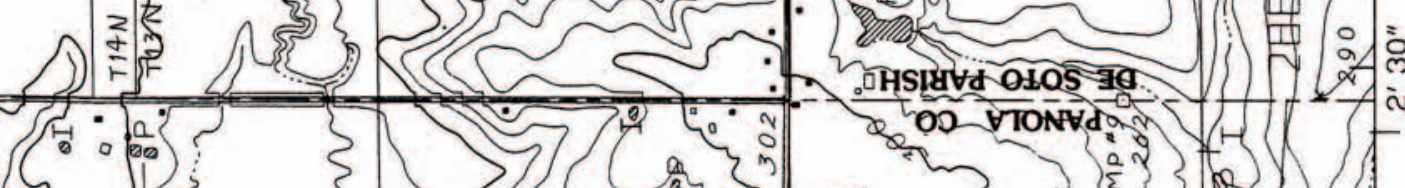

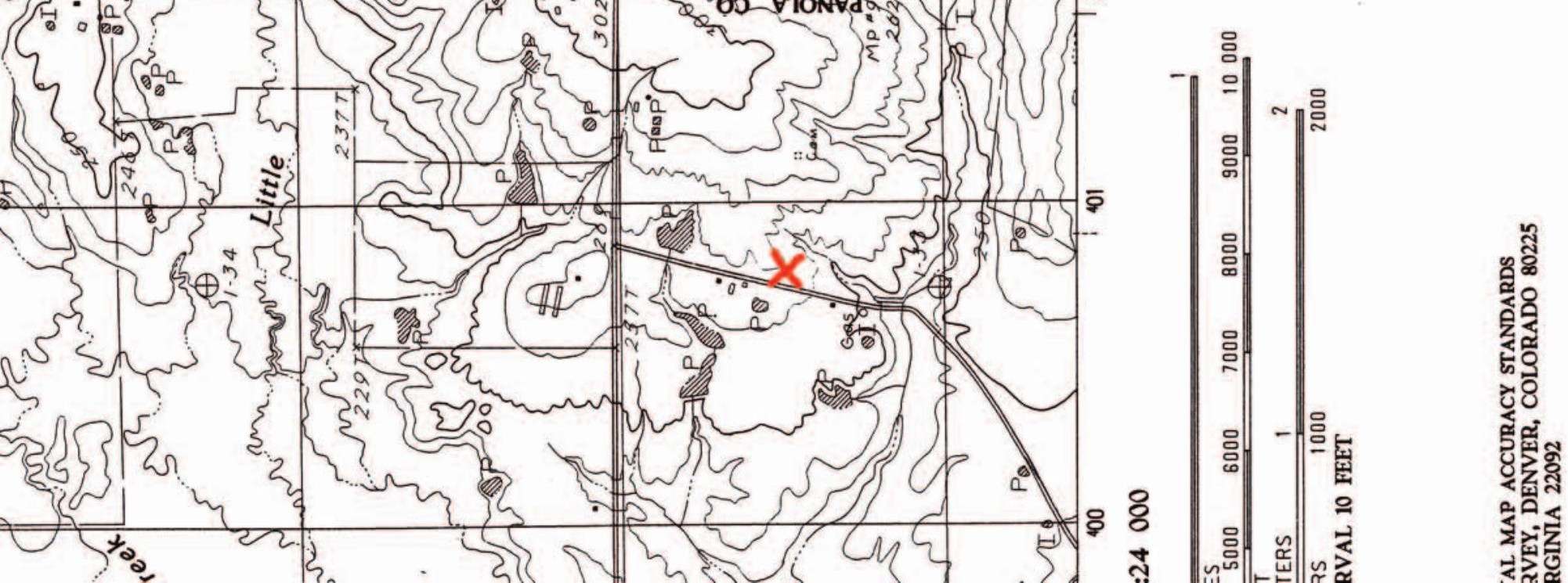




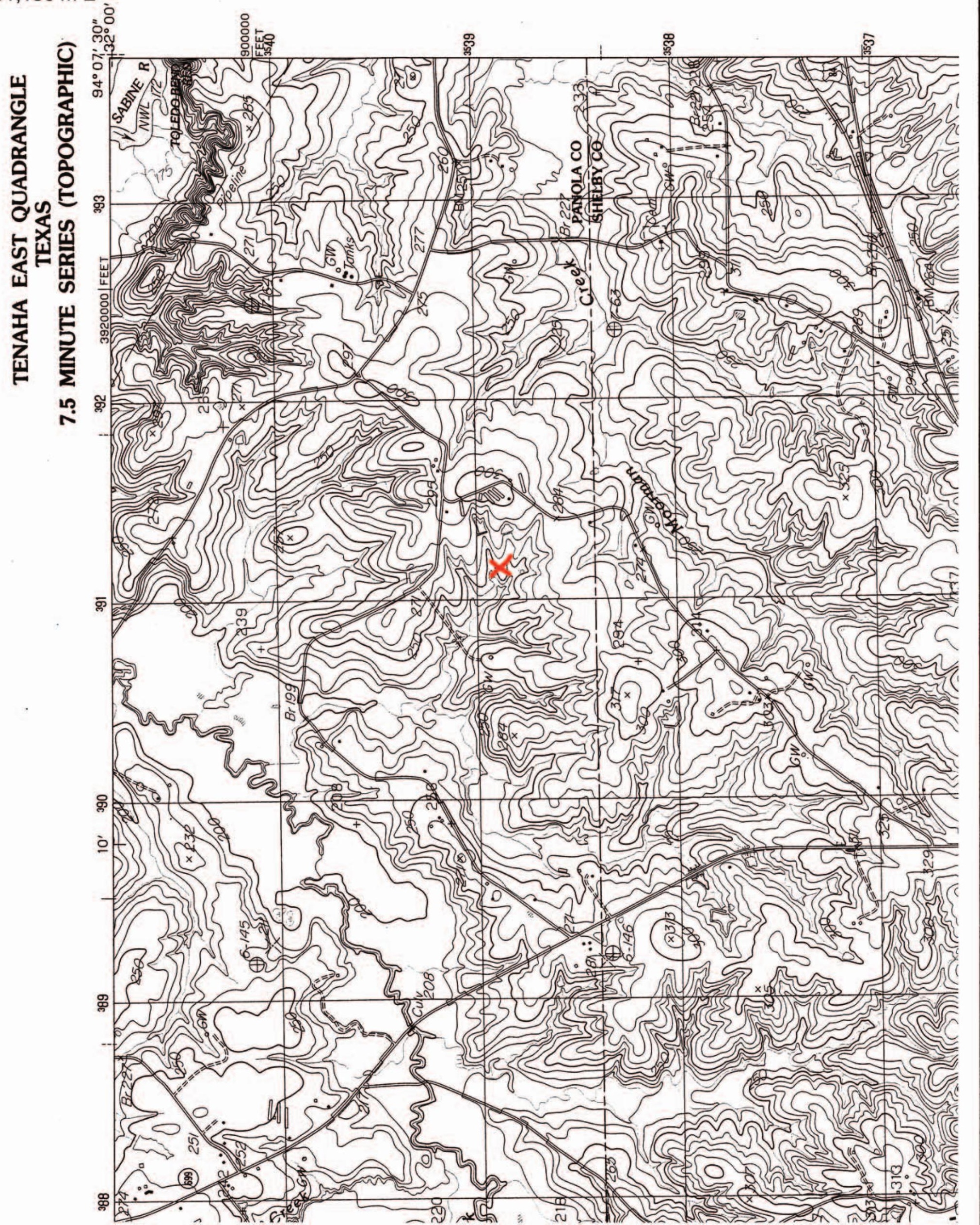




\section{RAILROAD COMMISSION OF TEXAS}

\section{SURFACE MINING AND RECLAMATION DIVISION \\ June 11, 1999}

Peter D. Warwick, Geologist

U.S. Geological Survey

Eastern Energy Resources Team

MS 956

Reston, Virginia 20192

RE: Coal Exploration Registration No. 328

Dear Mr. Warwick:

Coal Exploration Registration No. 328 has been assigned to the application received on June 7, 1999. Please refer to Exploration Registration No. 328 in future correspondence regarding this site. This notice expires on June 10, 2000.

Holes drilled to a depth not exceeding 500 feet are addressed in this notice. Separation between the lowest lignite seam and the top of any useable aquifers is necessary. Your proposal to plug all holes with Baroid's bentonite HOLEPLUG ${ }^{\mathrm{TM}}$ from total depth up to 13 feet below the ground surface, provided it is emplaced via downhole tubing, is satisfactory. In addition as proposed, all holes shall also have a cement surface plug placed at a depth from 3 to 13 feet below the ground surface and the surface area reclaimed.

Pursuant to requirements of $\S \S 12.331,12.332$, and 12.333 , any hole not already identified in the application that is not plugged immediately or is cased for use as a monitoring well, test well, or piezometer well, must be identified on a map or by State Plane coordinates, and the information promptly submitted to our office. Well depth and completion information, and measures taken for marking and protecting each well, must also be provided.

This registration must be renewed annually until all wells are either properly plugged and abandoned, or are transferred to the landowner with Commission approval. If a valid surface mining permit for the area is issued by the Commission, the drilling and plugging requirements contained in the approved permit document will also apply.

The Commission's Tyler Field Office must be notified at (903) 595-5501 prior to commencing any drilling and plugging activities. Should you have any questions concerning this registration, please contact Mr. Timothy Walter at (512) 463-7243.

Sincerely,

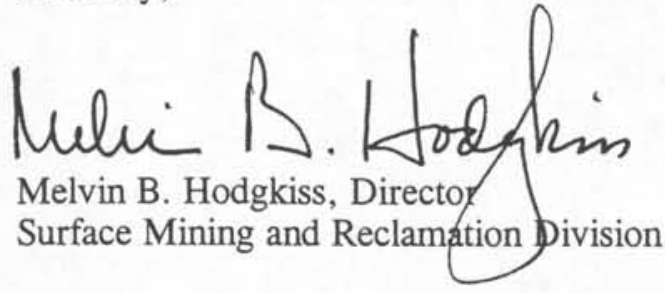

$\mathrm{MBH} / \mathrm{TGW} / \mathrm{flj}$

File Reference No. 199915802 


\section{Appendix 7}

\section{Raw Digital Files}

(Please note: raw digital data files associated with this chapter are accessible in the PDF version of this report or directly from the CD-ROM)

Appendix 7 of

Results of coalbed methane drilling in Panola County, Texas

Edited By Peter D. Warwick', John R. SanFilipo', Alex W. Karlsen', and Charles E. Barker ${ }^{2}$

'U.S. Geological Survey, Reston, VA

${ }^{2}$ U.S. Geological Survey, Denver, CO

Open-File Report 2005-1046

U.S. Department of the Interior

U.S. Geological Survey 


\section{Links to Raw Digital Files}

(Click on the tabbed links below or bookmarks to the left to open the associated file)

Coal Chemistry (Excel format)

USGS-PA-1 \& USGS-PA-2 Proximate/Ultimate Data

USGS-PA-1 \& USGS-PA-2 Trace Element Data

Methane Desorption (Excel format)
USGS-PA-2-CN1
USGS-PA-2-CN2
USGS-PA-2-CN3
USGS-PA-2-CN4
USGS-PA-2-CN5
USGS-PA-2-CN6
USGS-PA-2-CN7
USGS-PA-2-CN8
USGS-PA-2-CN9
USGS-PA-2-CN11
USGS-PA-2-CN12
USGS-PA-2-CN13
USGS-PA-2-CN14
USGS-PA-2-CN15
USGS-PA-2-CN16
USGS-PA-2-CN17

Methane Adsorption Isotherms (Excel format)
USGS-PA-2-CN2
USGS-PA-2-CN6
USGS-PA-2-CN12
USGS-PA-2-CN16

Carbon Dioxide Adsorption Isotherms (Excel format)

USGS-PA-2_CN2

Extended Langmuir Modeling (Excel format)

USGS-PA-2_CN2 
Petrographic Data (Excel format)

USGS-PA-2

Core LAS Files (ASCII format)

USGS-PA-1

USGS-PA-2 